\author{
UNIVERSIDAD NACIONAL DE LA PLATA \\ FACULTAD DE HUMANIDADES Y CIENCIAS DE LA EDUCACIÓN
}

SECRETARÍA DE POSGRADO

\title{
CONTROVERSIAS LIBERTARIAS: \\ LA INTERPELACIÓN ANARQUISTA EN TIEMPOS DEL PERONISMO
}

María Eugenia Bordagaray

Tesis para optar por el grado de Doctora en Historia

Directora Dra. Adriana María Valobra, UNLP-CONICET

Codirector Dr. Andrés Bisso, UNLP-CONICET

La Plata, 24 de junio de 2014 
ÍNDICE

$\begin{array}{ll}\text { RESUMEN } & 5\end{array}$

$\begin{array}{ll}\text { AGRADECIMIENTOS } & 7\end{array}$

Prólogo 9

$\begin{array}{ll}\text { INTRODUCCIÓN } & 13\end{array}$

Capítulo 1

SUJETOS, ACCIONES Y ORGANIZACIÓN DEL ANARQUISMO, 1930-1945 43

1. La fundación de la FACA 46

2. Las mujeres como sujetos movilizados 5

3. Los trabajadores: sindicalismo y acción política 58

4. Universitarios y movimiento estudiantil 68

5. Consideraciones finales 77

CApítulo 2

BIOGRAFÍAS E IDENTIDADES LIBERTARIAS

1. Inmigración y sociabilidades 85

2. Educación, juventud y socialización política 94

3. Luchas políticas, experiencias de vida e identidades

98 4. Las biografías en los repertorios organizacionales

110 del anarquismo

5. Consideraciones finales 116

\section{Capítulo 3}

INTERPELAR A LAS MUJERES, REDEFINIR OTREDADES

1. Polémicas con las políticas públicas peronistas 121

2. Sufragismo, feminismo y democracia en cuestión 1283.

La controversia anarquista con el sufragismo 132 peronista 
4. El agenciamiento político de las mujeres en el anarquismo.

5. Consideraciones finales

\section{Capítulo 4}

1. Una interpelación generizada y excluyente

2. La acción sindical: potencia y obstáculos

3. La "dignidad proletaria" y la demagogia peronista 1704.

La huelga como posibilidad de agenciamiento anarquista

\section{Capítulo 5}

SUJETOS DE LA ÚLTIMA TRINCHERA CONTRA EL "FASCISMO CRIOLLO"

1. De la Unión Democrática a la pulverización de las

188 alianzas

2. Religión y Estado: el avasallamiento de la autonomía y la democracia

3. Movilización estudiantil y agrupaciones de científicos e intelectuales

4. Jóvenes y universitarios en las estructuras organizativas libertarias.

5. Consideraciones finales 


\section{BIBLIOGRAFÍA} RESUMEN

Los estudios sobre los años que van de 1945 a 1955 han estado limitados por la hegemonía de las cronologías establecidas para describir el fenómeno peronista y aparece en la historiografía como una etapa autosuficiente y pocas veces problematizada. Fenómenos complejos como las trayectorias del movimiento obrero o de los partidos o movimientos políticos preexistentes al peronismo, son simplificados en consignas tales como colaboracionistasopositores, vieja guardianueva guardia sindical, etc. De esta manera, las acciones colectivas y las experiencias previas, de más largo plazo, son ignorados o solamente se identifican como "etapa previa" o posterior al peronismo. La cuestión que nos proponemos analizar necesita imponer sus propias periodizaciones o, por lo menos, cargar las antiguas de nuevos significados, en el sentido que las estrategias organizativas, las acciones colectivas e individuales de los libertarios que actúan en las controversias con el peronismo, comienzan a gestarse y tienen continuidad con las experiencias de la década anterior, a partir de 1930.

Pero el desafío de esta investigación no concluye en la visibilización de sujetos invisibilizados. Más bien, redoblaremos la apuesta al pensar este problema (que pretende ser historiográfico) desde nuevas perspectivas epistemológicas emparentadas con la sociología, la antropología y la filosofía. La novedad del abordaje no implica solamente incorporar nuevos autores, contemporáneos a la escritura de esta tesis, sino también construir una metodología propia, al entrecruzar estas perspectivas con la de los estudios de género y los de la historia política. Para comprender la dinámica del entrecruzamiento propuesto, quiero recordar aquí que las formas de abordaje de los sujetos de nuestra historia, se inscribe en dos planos. Un primer plano, que es el del análisis de las acciones de sujetos cuya identidad política coincide en el anarquismo; las trayectorias biográficas así como las conformaciones colectivas son los objetos de nuestro estudio. En un segundo plano, intentamos avanzar sobre las acciones llevadas a cabo por estos sujetos para enrolar a otros "sujetos" en su colectivo identitario, con el eje en la oposición al gobierno 
peronista: obreros, universitarios, y mujeres representan los sujetos sobre los que se disputan sentidos, identificaciones e interpretaciones. Las perspectivas definidas nos facilitan el análisis de estos dos planos, y las mismas se articulan en cada capítulo con otras perspectivas y abordajes específicos.

Por último, en nuestra investigación, señalamos que los procesos de configuración del anarquismo sufrieron transformaciones en algunos aspectos en el período anterior al peronismo y que, en el contexto de los dos primeros gobiernos de Perón, algunas continuaron y se reforzaron y otros, se modificaron. Es por ello que partiremos de pensar al colectivo libertario durante el peronismo como a un actor cuya identidad se encuentra en curso de negociación, por lo que también identificaremos a los actores con los que sostiene las controversias partiendo de sus propias definiciones.

PALABRAS ClAVES: ANARQUISMO - CONTROVERSIAS - PERONISMO 


\section{Agradecimientos}

\section{“Lleva, llevamos, un papel arrugado en la mano temblorosa. No es fácil}

hablar. Hay un silencio medroso alrededor. Es todo demasiado extraño, imprevisible. Lo extiendo, lo desarrugamos con los dedos de palo. Las inscripciones están fracturadas por el tiempo, la torpeza, la vejez de la escritura. Sin embargo ahí están todos los signos. Ahí o en ninguna parte. Eso es todo lo que hay que entender".

Armando Tejada Gómez. El Río de la Legua.

Torres Agûero Editor, 1991.

Fueron muchos los años transcurridos entre el comienzo de esta investigación y su culminación. En primer lugar quisiera agradecer al Consejo Nacional de Investigaciones Científicas y Técnicas por el financiamiento otorgado en forma de Beca Tipo 1 y Tipo 2. Al Centro Interdisciplinario de Investigaciones en Género (CINIG-IDIHCS) por brindarme un espacio institucional acorde a lo que las tareas de investigación demandan. En tercer lugar, a mi directora, Adriana Valobra, de quien aprendí el oficio, las mañas, los atajos, el trabajo duro y responsable. A Andrés Bisso por su mirada atenta y sagaz sobre mis escritos, ensayos y borradores. A mis compañeras de estudio, luego de trabajo, Nadia Ledesma Prietto y Anabella Gorza. Con ellas hemos aprendido a desempeñarnos en las tareas de investigación, hemos conocido los claustros, nos hemos formado; pero también, hemos transitado juntas el camino de la vida. Agradezco también a todos aquellos y aquellas que en alguna oportunidad comentaron mis avances de investigación y me ayudaron a solucionar los "problemitas" que allí aparecían, en especial a Andrés Stagnaro. A mi compañera de la carrera de Historia y amiga, Alejandra Flammini, por los ratos compartidos, por las horas de estudio, de trabajo y de debate. A Gisela Manzoni por el relevamiento de la documentación. También agradezco a Pablo Zubiaurre, mi profesor de historia y también historiador, quien me mostró tempranamente de qué iba el oficio del historiador. Sin dudas sus enseñanzas y certezas, transmitidas a mí 
literalmente con "los pies metidos en el barro", marcaron definitivamente mis inclinaciones académicas.

Quiero agradecer especialmente a mis padres. Su confianza y apoyo incondicional respecto a cada uno de los pasos que he dado me permitió pensar y hacer las cosas que siempre quise, entre ellas la investigación. A mis hermanos Joaquín, Ricardo y Rosario, también por su confianza y acompañamiento. A Carlos y a Norma, sin cuyo apoyo todo este camino hubiera sido imposible de recorrer.

Por último, agradezco a Diego por la vida que hemos construido juntos, por la compañía, el respeto, el apoyo constante, el diálogo y el amor. Como todos dicen, las horas dedicadas a este trabajo seguramente fueron robadas de las necesarias para el sueño, para las tareas de la casa, para el cuidado de los chicos, para los juegos, etc. A Valentín y Mateo, con quienes compartimos la vida y con quienes podemos imaginar un futuro amoroso, solidario y tolerante. A ellos especialmente, está dedicada esta tesis. 


\section{Prólogo}

Escribir sobre los orígenes de la presente investigación resultó ser una tarea compleja. Sin duda, mis primeros interrogantes no tienen un origen científico. La pregunta que me orbita desde mis años adolescentes, tiempos en que se comienza a descreer del mundo que los adultos nos presentaron, se relaciona con las experiencias e identificaciones políticas familiares. Luego, vendrán las inconformidades con lo que la historiografía ha visibilizado. En tercer lugar, la incomodidad con las voces que la historiografía ha callado.

Primer punto de disconformidad. El compromiso de mi padre con la militancia política en el radicalismo local (el de Ayacucho, mi pueblo) marca nuestros itinerarios familiares: viajes al campo para coordinar encuentros entre los simpatizantes alfonsinistas, trabajo en el comité local, almuerzos, cenas reuniones, juegos, festejos, desilusiones y vuelta a empezar. De la mano de este trabajo militante, que en mi recuerdo sucede aproximadamente entre los años 1983 y 1987, hay una idea que persiste latente en la militancia por la causa radical, que guía y construye el imaginario del radicalismo que yo conocí: el del antiperonismo. De esto no se hablaba en los discursos oficiales cuando ser oficialista significaba ser radical, con Alfonsín en la presidencia. El antiperonismo gravitaba como trasfondo, era el "otro" negativo que ayudaba a construir el yo propio del radicalismo que yo conocí. No se trataba de ideología, más bien de una cosmovisión. Mis dudas se acrecentaron cuando descubrí que existía una suerte de "hermandad" secreta entre todos (los militantes del pasado y los presentes, los individuos y los grupos de la izquierda, socialistas, comunistas pero también de la derecha conservadora y liberal), los “antiperonistas". Aún no podía acercarme a una definición concreta de qué significaba, pero empiezo a comprender cuáles cuestiones estaban presentes allí, entre quienes no se dicen pero se piensan antiperonistas: comienza con el rechazo hacia la figura de Juan Domingo Perón, continúa con el Partido Peronista (el de los 40, el de los 70, los 80, los 90 y el actual), pero también se rechaza al movimiento peronista, al sindicalismo peronista, a la política social peronista, a la 
política económica peronista etc. La pregunta reaparece finalizando mis estudios de grado, buscando pistas como asistente de investigación sobre las identidades políticas de los chacareros pampeanos en tiempos del primer gobierno peronista.

Segundo punto de disconformidad: La pregunta que genéricamente abre la historia de las mujeres es ¿Dónde estaban ellas cuando...? Remitiendo a mis intereses por los sectores agrarios y el peronismo-antiperonismo, las preguntas acerca de la ciudadanía política de las mujeres en tiempos en que la misma es disputada (tiempos del primer peronismo, tiempos de la sanción del voto femenino) escarba aún más en mis intereses ya atravesados por la perspectiva de género como prisma para observar "la historia". La militancia de las mujeres y los debates que las mismas plantean a la perspectiva hegemónica acerca de la participación política de las mujeres en tiempos del peronismo retendrán provisoriamente mi atención y abrirán un horizonte nuevo de preguntas y problemas a resolver(me).

Tercer punto de disconformidad: Hace poco más de 6 años, antes de comenzar esta investigación, el campo historiográfico limitaba la posibilidad de existencia del anarquismo a la primera década del siglo XX. El problema del anarquismo como movimiento social y político complejo había sido obturado como tal por ese mismo discurso historiográfico que imponía su clausura. Experiencias como las de las huelgas patagónicas descriptas y denunciadas por Osvaldo Bayer en los años 60/70, o los aportes de las investigaciones internacionales que advertían sobre la dinamicidad de los colectivos libertarios de mujeres en el Río de la Plata en los años 20 y 30 se diluían frente a la gran estructura que los estudiosos del anarquismo local habían armado. ¿Qué hubieran pensado los anarquistas (si aún existiesen) del peronismo? ¿Qué hubieran dicho las mujeres anarquistas sobre las "posibilidades" que el sufragio abre a su universo? Bastó una visita al Archivo de la Federación Libertaria Argentina para comenzar a armar este rompecabezas, compuesto de preguntas, dudas, vacíos y sólo una certeza: la necesidad de recuperar todas esas voces dispersas, contradictorias, que lejos de haberse acallado, habían sido ignoradas, y clamaban aún vigorosas a la luz del archivo.

Entonces, el recorrido por el cual llegaremos a elaborar nuestro problema de investigación es sumamente complejo, subjetivo, empírico, experiencial y se relaciona directamente con el hallazgo de fuentes que "hacen hablar" a sujetos que los historiadores habíamos invisibilizado. Sin embargo, a la luz del antiperonismo 
(ese complejo dilema de la infancia), las voces de las mujeres que dialogan y controvierten con el peronismo en tiempos en que los sentidos de la ciudadanía política está en disputa, comenzamos a desandar las agencias libertarias en diálogo con el peronismo en el poder.

En resumen, dejando atrás el origen biográfico que tiñen las preguntas que nos llevan a construir el problema, avanzaremos en los pasos comunes a los trabajos científicos. Hablaremos de lo que se ha escrito hasta ahora, qué es lo que falta, de qué modo lo haremos y cuál es la originalidad de nuestro planteo. 


\section{INTRODUCCIÓN}

\section{Anarquismo e historiografía}

La historia del anarquismo en Argentina ha concitado especial atención de quienes investigan y ello es especialmente cierto para la etapa que corre entre fines del siglo XIX y las dos primeras décadas del 20, que ha sido visualizada como la de esplendor del colectivo libertario. La cita que encabeza el presente capítulo nos coloca frente a la prevalencia de este recorte temporal en investigaciones recientes sobre el anarquismo. Historiar al anarquismo y su trayectoria en el movimiento obrero entre 1890 y 1930, había sido, hasta no hace mucho tiempo atrás, objeto de la atención de algunos intelectuales anarquistas. Podemos pensar en los casos de Diego Abad de Santillan y Sebastián Marotta, entre muchos otros. ${ }^{1}$ Esta

"historia" desde adentro aporta fundamentalmente información detallada, un gran corpus documental, pero puede adolecer de "sentido crítico" en relación al elemento político en el que actúan y al que historizan. Como bien lo dice Hernán Camarero, la historia contada desde dentro por los mismos militantes e ideólogos de los movimientos y partidos políticos,

$$
\begin{aligned}
& \text { “(..) Aportaron mucha información empírica, de la cual se } \\
& \text { abastecieron estudios posteriores, pero nunca pudieron superar el } \\
& \text { plano descriptivo. Los hechos se suceden uno tras otro sin mayor } \\
& \text { jerarquización o análisis. A pesar de que frecuentemente fueron } \\
& \text { enunciadas como historias del movimiento obrero, fueron más bien } \\
& \text { genealogías de la elite gremial y reseñas cronológicas del entramado } \\
& \text { sindical y de sus diferentes estructuras de liderazgo, lo que dejó }
\end{aligned}
$$

\footnotetext{
${ }^{1}$ Abad de Santillán, D. (1930). El movimiento anarquista en la Argentina. Buenos Aires: Argonauta. Marotta, S. (1960). El movimiento sindical argentino: su génesis y desarrollo (Vol. 1). Ediciones" Lacio,". 
ausente en el recorrido muchas otras dimensiones acerca de aquel actor". 2

Abad de Santillán deja testimonio de sus intenciones al abordar la historia de la FORA, al afirmar que

“(...) la historia del proletariado de América la hizo la FORA; ella fue la que puso un coto a los desbordes del enemigo y la que simboliza toda la acción proletaria y revolucionaria de defensa y ofensa". ${ }^{3}$

Pero las motivaciones de estas escrituras no se agotan en el sentido reivindicativo de los movimientos políticos o sindicales a los que pertenecen. Debe considerarse también que fueron herramientas de acción política con las que estos militantes, dedicados al trabajo intelectual a la vez que comprometidos con su tiempo y sus ideas, intervienen en la arena política, con las cuales entran en discusión con el Estado, la sociedad civil y el resto de las tendencias políticas. Volviendo a la historia de la FORA de Abad de Santillán, escrito entre 1930 y 1933, expresa claramente la urgencia y necesidad de reivindicar y mantener gravitante el espíritu de la organización anarquista en tiempos de represión y persecución:

“Militantes y propulsores de esa organización, convertida en símbolo de emancipación y de justicia, desafiamos con las siguientes páginas que siguen en el ensañamiento de los perseguidores; al exponer lo que ha sido, anunciamos lo que será, convencidos de la inutilidad práctica de toda represión". 4

\footnotetext{
${ }^{2}$ Camarero, H. (2005) "La izquierda como objeto historiográfico. Un balance de los estudios sobre el socialismo y el comunismo en la Argentina", en Nuevo Topo. Revista de historia y pensamiento crítico. $\mathrm{N}^{\mathrm{o}}$ 1.Pag. 80

${ }^{3}$ Para el presente trabajo hemos consultado una versión actualizada de la obra de Diego Abad de Santillán. de Santillán, D. A. (2005). La FORA: ideología y trayectoria del movimiento obrero revolucionario en la Argentina. Libros de Anarres. Pag. 295

${ }^{4}$ Ibid, pag. 51

Bordagaray, M. E. Controversias libertarias: la interpelación anarquista en tiempos del peronismo
} 
Dentro del grupo de estudios renovadores de la temática anarquista, Zaragoza Rovira y Capelletti, también ven un quiebre y la decadencia del anarquismo en los mismos años que los estudios que anteceden. ${ }^{5}$ Juan Suriano destaca la difusión de las ideas libertarias en ámbitos no exclusivamente obreros, delimitando las distancias entre bases y vanguardias del movimiento, así como recalando en las particularidades de la praxis anarquista a través de sus diarios, publicaciones, proyectos educativos y reuniones culturales en las que el ideario ácrata parece haberse plasmado, paralelamente a la labor sindical en los primero años del Siglo XX. Sin embargo, cita su decadencia apenas comenzada la década del $10{ }^{\circ}{ }^{6}$

Las investigaciones han sido más parcas sobre el desarrollo del anarquismo durante la década del ' 30 , en el supuesto de que sus militantes fueron brutalmente reprimidos por el primer gobierno de facto en Argentina. La deportación, cárcel y asesinato de los militantes habría silenciado las prácticas ácratas. Estas investigaciones acuerdan también que existió una imposibilidad de conciliar intereses que entre las diversas tendencias del anarquismo en el Río de la Plata. Particularmente, se ha enfocado la discusión en torno a la incongruencia políticoideológica que implicaba crear una organización entre quienes se oponen a cualquier tipo de determinación orgánica para sus acciones y las dificultades para sostener el ideario ácrata en el escenario político y social pos golpe de 1930. Como bien indica Omar Acha, estas interpretaciones creen que el problema del anarquismo “(...) reside en el diseño de una estrategia inadecuada para una sociedad en proceso de modernización y democratización". 7 De este modo, la Ley Sáenz Peña y la consecuente participación política popular a través de la presidencia de Irigoyen, la aparición de una cultura de masas, así como también ciertas mejoras en las condiciones económicas y laborales de los trabajadores habrían obturado la capacidad del movimiento libertario para hacerse eco de nuevas

\footnotetext{
5 Capelleti, Angel (1990). El anarquismo en América Latina. C. M. Rama (Ed.). Fundación Biblioteca Ayacucho. Zaragoza Rovira, Gonzalo (1996). Anarquismo argentino, 1876-1902. Medir, Ediciones de la Torre.

${ }^{6}$ Suriano, Juán (2001). Anarquistas: cultura y política libertaria en Buenos Aires, 1890-1910. Buenos Aires, Manantial.

${ }^{7}$ Acha, Omar (2009), Historia crítica de la historiografía argentina: las izquierdas en el siglo XX, vol. 1. Buenos Aires: Prometeo. Pág. 95.
} 
problemáticas que los interpelen, ya no ligadas a la mejora de la calidad de vida por vías revolucionarias. ${ }^{8}$

Estas interpretaciones explican la falta de consecución de los estudios sobre el anarquismo más allá de la década del 20`. Los trabajos de Bayer sobre Severino Di Giovanni y el movimiento anarquista expropiador, aportan elementos para la reconstrucción del ideario y accionar de los anarquistas antes y durante los primeros años de la "Década Infame". El autor recupera nombres y acciones de anarquistas como Miguel Arcángel Rosigna, Karl Wilckens, Juan Antonio Morán así como también redes de relaciones, espacios de reuniones, publicaciones e historias libertarias en varios puntos del país. Sin duda, este ha sido el principal aporte de Bayer, el de visibilizar agencias diferenciadas en el movimiento anarquista en espacios geográficos que escapan a los tradicionalmente conocidos por los estudiosos de las ideas libertarias. Los sucesos de la "Patagonia Trágica", en los que la mayor parte de los peones rurales que exigen reformas en las condiciones laborales a sus patrones se movilizan bajo la bandera anarquista y son asesinados por la policía en connivencia con estancieros y el gobierno de Irigoyen, fueron conocidos popularmente a partir de las sus investigaciones. ${ }^{9}$

Sin embargo, recientemente, López Trujillo ha visibilizado la presencia del anarquismo a partir del estudio de la formación de la Federación Anarco Comunista

\footnotetext{
${ }^{8}$ Luciana Anapios interpreta bajo esta perspectiva el quiebre del anarquismo tal como se lo conoce hasta la década del 20: "el lugar preponderante del anarquismo iban a cambiar lentamente durante la segunda década del siglo XX. A esto contribuyeron tanto la represión al movimiento a partir del Centenario de 1910, como las transformaciones en el sistema político y en la sociedad civil tras la reforma electoral y los sucesivos gobiernos radicales (...) se sumó la irrupción de la cultura de masas, con la radio, el cine, el fútbol y una industria editorial variada que competía con la cultura de izquierda por el mismo público lector. (...) Durante la segunda mitad de la década, frente al declive de su influencia en el movimiento obrero y el alejamiento de algunos militantes e intelectuales, las querellas internas se multiplicaron.(...) Anapios, Luciana (2011). "Una promesa de folletos. El rol de la prensa en el movimiento anarquista en la Argentina (1890-1930)", en $A$ contracorriente. Una revista de historia social y literatura en América Latina. Vol. 8, No. 2, Winter. www.ncsu.edu/project/acontracorriente. Desde una perspectiva similar, Petra, Adriana (2001). "Anarquistas: cultura y luchas políticas en la Buenos Aires finisecular. El anarquismo como estilo de vida", http://www.biblioteca.clacso.edu.ar/subida/clacso/becas/20101111073154/petra.pdf.

${ }^{9}$ Citamos aquí los trabajos en los que Bayer aborda el tema: Bayer, Osvaldo (1970). Severino Di Giovanni, el idealista de la violencia. Buenos Aires, Editorial Galerna. Bayer, O. (1972) La Patagonia rebelde (tomos I y II). Buenos Aires, Editorial Galerna. Bayer, O. (1974) La Patagonia rebelde (tomo III). Editorial Galerna. Bayer, O. (1975). Los anarquistas expropiadores y otros ensayos. Editorial Galerna. Bayer, O. (1975) La Patagonia rebelde (tomo IV), Berlín (Alemania), entre otros.
} 
Argentina (FACA), en 1935. ${ }^{10}$ Hasta hace pocos años, era el único antecedente de un intento sistemático de estudiar el silenciado movimiento anarquista de los años 30 y 40 a través de una investigación histórica. Un estudio minucioso basado en fuentes novedosas y un trabajo exhaustivo de reconstrucción de biografías y trayectorias, en el que el autor no oculta su sintonía con el ideario anarquista. Logra construir una red de relaciones personales y organizaciones sindicales y políticas a lo largo y ancho de la Argentina, así como también la participación en España desde 1936 y la vuelta a la actividad en la Argentina en los años 40.

Por otro lado, Nicolás Iñigo Carrera y Javier Benyo analizan una de las facciones del movimiento ácrata que aparece a mediados de la década del 30': la Alianza Obrera Spartacus, cuyas acciones fueron fundamentales para visibilizar el amplio abanico de las orientaciones libertarias y sus formas específicas de organización. $^{11}$ Asimismo, de manera colateral, los estudios que tratan la movilización política durante el período entreguerras, en particular la relacionada con la Guerra Civil Española, hablan de las actividades anarquistas en la Argentina. Esta actividad puede percibirse en las publicaciones como Timón, dirigida por Abad de Santillán, en la gran cantidad de militantes anarquistas que adhieren a la causa republicana sumándose a las filas de la resistencia (por ejemplo, José Grunfeld y Ana Piacenza, entre otros), y la organización de sociedades y juntas de solidaridad con las víctimas del fascismo y de propaganda de la causa antifascista.

Tras la veta iniciada por Dora Barrancos, cuyo trabajo señero significó no solamente analizar el anarquismo desde nuevas perspectivos sino también incluir los relatos de las mujeres y la perspectiva de género, varias investigaciones han retomado la temática de las mujeres anarquistas. ${ }^{12}$ Mirta Lobato, Marcela Nari, María del Carmen Feijoo, Mabel Belucci, Cristina Guzzo, Maxine Molyneux, Leonor Calzetta, Claudia Bacci y Laura Fernández Cordero han subrayado las

\footnotetext{
${ }^{10}$ López Trujillo, F. (2005). Vidas en Rojo y negro. Una historia del anarquismo en la Década Infame. Letra Libre, La Plata.

${ }^{11}$ Iñigo Carrera, N. (2006). "Alternativas revolucionarias en los treinta: la alianza obrera Spartacus y el Partido Socialista Obrero", en Biagini, Hugo y ROIG, Arturo (comps.) El pensamiento alternativo en la Argentina del siglo XX, Biblos, Buenos Aires, 319-342. Benyo, J. (2005). La alianza obrera Spartacus: anarquismo, vanguardia obrera e institucionalización del movimiento sindical en la década de 1930. Libros de Anarres.

${ }^{12}$ Barrancos, Dora. (1990a). Anarquismo, educación y costumbres en la Argentina: de principios de siglo. Buenos Aires, Editorial Contrapunto.
} 
interpretaciones particularísimas de las anarquistas en relación a la ciudadanía sexual, la beligerancia de sus demandas tanto dentro como fuera del movimiento y las empresas culturales y políticas que llevaron adelante pensadas como producciones de y para mujeres. ${ }^{13}$ La reconstrucción de los itinerarios de vida de varias militantes ácratas ha tenido un impulso en los últimos años. Así, en el caso de Salvadora Medina Onrubia de Botana, Virginia Bolten y Juana Rouco Buela y, a pesar de las dudas acerca de la adscripción o no a las ideas ácratas, en el de Herminia Brumana. ${ }^{14}$ Sin embargo, en estos casos, el interés ha estado más concentrado en sus creaciones artísticas, las que trascienden a sus agencias en el movimiento libertario o anarquista. Este rico panorama de investigación pierde continuidad para analizar los recorridos del anarquismo durante la década de los primeros gobiernos peronistas

Los avances en estudios de doctorado han aportado al estudio del anarquismo, avanzados los años 40, puntualmente en las agencias sindicales y la activación en la cuestión obrera. ${ }^{14}$ En esta línea, cabe destacarse el trabajo de Adrián Ascolani, quien visibiliza una fecunda y extendida actividad sindical en la zona pampeana como parte de las acciones organizativas de militantes faquistas y foristas al finalizar la década del $30 .{ }^{15}$ En los últimos años también, algunos

\footnotetext{
${ }^{13}$ Lobato, Mirta (2007). Historia de las trabajadoras en la Argentina (1869-1960), Buenos Aires, Edhasa. Nari, Marcela (2004). Políticas de maternidad y maternalismo politico. Buenos Aires, 1890-1940, Editorial Biblos. Feijoo, María del Carmen (1990). "Las trabajadoras porteñas a comienzos del siglo", en Armus, Diego. Mundo urbano y cultura popular. Estudios de Historia social Argentina. Buenos Aires, Sudamericana, 281-312. Belluci, Mabel (1990). "Anarquismo, sexualidad y emancipación femenina. Argentina alrededor del 900." Nueva Sociedad, 109. Guzzo, Cristina (2003). Las anarquistas rioplatenses 1890-1990. Editorial Orbis Press. Molyneux, Maxine (1997). "Ni Dios, ni Patrón, ni marido", en La voz de la mujer. Periódico comunista anárquico, Universidad Nacional de Quilmes. Calzetta, Elsa (2005). Nuestra tribuna: Hojita sentir anárquico femenino, 1922-1925. Bahía Blanca, Editorial de la Universidad Nacional del Sur. ${ }^{14}$ Sobre la figura de Salvadora: Saítta, Sylvia (1995). "Anarquismo, teosofía y sexualidad: Salvadora Medina Onrubia". Revista Mora, $N^{o}$ 1, 51-59. Saítta, Sylvia (1998). Regueros de tinta: el diario" Crítica" en la década de 1920. Sudamericana. Sobre Juana Rouco y Virginia Bolten: Guzzo, Cristina (2003). Las anarquistas..., op. cit. Los primeros abordajes académicos sobre la figura de Brumana, los encontramos en Fletcher, Lea (1987). Una mujer llamada Herminia. Catálogos Editora.

${ }^{14}$ Nieto, Agustín (2008). "Conflictividad obrera en el puerto de Mar del Plata: del anarquismo al peronismo. El Sindicato Obrero de la Industria del Pescado, 1942-1948”, en Revista de Estudios

Marítimos y Sociales, $\mathrm{N}^{\circ}$ 1, 35-44. Ceruso, Diego (2011). "El trabajo sindical de base del anarquismo argentino: la FACA y la Alianza Obrera Spartacus.", en A Contracorriente, $\mathrm{N}^{\circ} 8$, 233254. Pascucci, Silvina (2007). Costureras, monjas y anarquistas: trabajo femenino, Iglesia y lucha de clases en la industria del vestido, Buenos Aires, 1890-1940 (Vol. 2). Ediciones RyR.

${ }^{15}$ Con faquistas referimos a los adherentes a la Federación Anarco Comunista de la Argentina (FACA). Foristas son los aliados a la Federación Obrera Regional de la Argentina (FORA). Ascolani, Adrián (2009). El sindicalismo rural en la Argentina: de la resistencia clasista a la comunidad organizada, 1928-1952. Universidad Nacional de Quilmes.
} 
investigadores dedicados al estudio del la izquierda y el mundo intelectual, reconocen una deuda con las agencias anarquistas y su trabajo cultural en la creación de editoriales, publicaciones y prensa partidaria. Es el caso de Osvaldo Graciano, quien, retomando el estudio sobre los anarquistas universitarios en los 40 profundiza, con posterioridad a la publicación de su trabajo doctoral, en las ediciones de la Unión Socialista Libertaria, Ediciones Nervio e Imán ${ }^{16}$ De todos modos, estas publicaciones carecen de una trama profunda que vincule el trabajo editorial con la organización política a la que pertenecen, así como también adolecen de sentido crítico en torno a los agencias ácratas invisibilizadas por la mayor parte de las investigaciones que le son contemporáneas. Es decir, representan pequeños abordajes de temas más amplios que, sin embargo, nunca tienen como objeto de investigación a los colectivos libertarios, su trabajo cultural, sindical y las agencias y trayectorias individuales/grupales de quienes los sostienen. Creo que el relato de una historia cultural o intelectual, pierde de vista la singularidad y las posibilidades (materiales, políticas, laborales, familiares) que inevitablemente confluyen para perfilar los caminos de la acción política.

Reconociendo las historias narradas por militantes (con un amplio y sólido trabajo documental); el de la historiografía (que avanza en el estudios de las prácticas culturales, organizacionales, educativas y editoriales del anarquismo hasta los albores de 1930) y la de aquellos que persiguen la pista "obrera" dentro de las variantes ideológicas del movimiento libertario entrados los años 40, nuestra investigación propone que las características que definen al anarquismo como movimiento obrero de masas en las primeras tres décadas del siglo XX, se transforman para los años de nuestro estudio.

El problema que percibimos en la historiografía es que ha visibilizado el anarquismo y ha concluido en su lenta desaparición hacia la llegada del peronismo se explica por no haber comprendido la transformación del sujeto revolucionario al que apela el anarquismo así como tampoco haber profundizado en el perfil del militante anarquista posterior a 1930. Como veremos en las siguientes páginas, predomina en sus acciones la apuesta por el cambio cultural, a través del

\footnotetext{
${ }^{16}$ Graciano, Osvaldo (2008). Entre la torre de marfil y el compromiso político: intelectuales de izquierda en la Argentina, 1918-1955. Universidad Nacional de Quilmes. Graciano, O. (2012) "La escritura de la realidad. Un análisis de la tarea editorial y del trabajo intelectual del Anarquismo argentino entre los años '30 y el Peronismo", www.izquierdas.cl, 12 de abril, pp. 72-110. Bacci, Claudia y Fernández Cordero, Laura (2007) "Feroces de lengua y pluma. Sobre algunas escrituras de mujeres anarquistas", en Políticas de la Memoria, NN$^{\circ}$ 6/7. CEDINCI, Buenos Aires.
} 
enrolamiento de las mujeres, los universitarios y la juventud, y de manera equiparable, los obreros. En otras palabras, nos proponemos analizar las estrategias de acción política del anarquismo, en torno al establecimiento de temas y sujetos de disputa con el peronismo: las mujeres, los obreros y los estudiantes y universitarios. En torno a este problema general, intentaremos describir las modalidades de organización de varones y mujeres anarquistas, en el período 1935-1955 en Argentina. En segundo lugar, intentaremos especificar de qué manera estas controversias repercuten en la estructuración de las prácticas anarquistas en su condición de oposición al gobierno. Delinear las modificaciones que el anarquismo realizó en sus discursos e intervenciones en relación a la ciudadanía política, como también observar el rol que le adjudican a "el obrero" en la "Nueva Argentina" peronista y cuál es la propuesta anarquista para ellos. ${ }^{17}$ Por último, intentaremos abordad algunos de los núcleos urbanos más dinámicos en relación con la acción anarquistas de estos años como Buenos Aires, Rosario, Mar del Plata, Bahía Blanca y La Plata, cuestión que va de la mano con las biografías de quienes sostienen las organizaciones anarquistas a lo largo del tiempo que abarca nuestro estudio.

Hasta hace poco, se había supuesto que el peronismo había obturado toda manifestación opositora y, a la vez, había terminado con una movilización de varones y mujeres creciente durante la entreguerras. ${ }^{18}$ Las investigaciones han enfocado su atención en lo que marcan como tensiones durante el período tales como la obtención de la ciudadanía política para las mujeres ocurrida durante el primer gobierno peronista y una movilización política realizada especialmente por el oficialismo con visos verticalistas. ${ }^{19}$ No obstante, recientemente, algunos estudios han demostrado que aquellos sujetos políticos redefinieron sus estrategias

\footnotetext{
${ }^{17}$ La idea de la "Nueva Argentina" es instalada por los sectores políticos que acompaña la presidencia del Juan D. Perón. Refieren al nacimiento, de la mano del peronismo, de una nueva sociedad basada en la justicia social, la inversión pública y la participación popular en el sostenimiento del régimen vigente. Comienza mención a la "Nueva Argentina", comienza a aparecer alrededor de 1949, año en que también se debaten reformas a la constitución y al régimen jurídico vigente.

${ }^{18}$ Gutiérrez, Leandro y Romero, Luis Alberto (2007). Sectores populares, cultura y política: Buenos Aires en la entreguerra. Siglo Veintiuno Editores Argentina.

${ }^{19}$ Bianchi, Susana y Sanchís, Norma (1988). El partido peronista femenino. Centro Editor de América latina.. Barry, Carolina (2009) Evita capitana: el Partido Peronista Femenino, 1949-1955. EDUNTREF, Editorial de la Universidad Nacional de Tres de Febrero. Navarro, Marysa (2007). Evita Buenos Aires. Editorial Edhasa. Plotkin, Mariano (1994). Mañana es San Perón: Propaganda, rituales políticos y educación en el régimen peronista (1946-1955). Buenos Aires, Ariel.
} 
de organización, participación y movilización política. ${ }^{20}$ En ese sentido, nuestra investigación se inscribe en esa línea y subraya el vacío historiográfico que se ha mantenido respecto de las estrategias ácratas.

Sin embargo, a la luz del estado actual de la investigación, se hace atractiva la pregunta acerca de cómo encararon esa movilización política los movimientos y partidos preexistentes al peronismo. En esa nueva empresa y teniendo en cuenta las características del contexto de movilización política femenina durante el peronismo, las mujeres recobraron un papel crucial para el anarquismo. Siguiendo a Joan Scott, entendemos que la perspectiva del género ha aportado a la historia la posibilidad de realizar nuevas preguntas, ampliar las perspectivas de análisis y permitir la elaboración de hipótesis que incluyan la perspectiva relacional de las vinculaciones sociales entre los sexos. ${ }^{21}$ En ese caso, resulta útil indagar cómo desde el anarquismo fue necesario construir alocuciones contestatarias al discurso que modelaba el peronismo.

Los estudios sobre los años que van de 1945 a 1955 han estado limitados por la hegemonía de las cronologías establecidas para describir el fenómeno peronista y aparece en la historiografía como una etapa autosuficiente y pocas veces problematizada. $^{22}$ Fenómenos complejos como las trayectorias del movimiento obrero o de los partidos o movimientos políticos preexistentes al peronismo, son simplificados en consignas tales como colaboracionistasopositores, vieja guardianueva guardia sindical, etc. ${ }^{23}$ De esta manera, los fenómenos y las experiencias

${ }^{20}$ Acha, Omar (2004). "Sociedad civil y sociedad política durante el primer peronismo", en Desarrollo económico, 199-230. Valobra, Adriana (2005 a). "Tradiciones y Estrategias de

Movilización Social en los Partidos Opositores Durante el Peronismo. El Caso del Partido Comunista y la Unión de Mujeres de la Argentina”, en Canadian Journal of Latin American and Caribbean Studies, 30(60), 155-182. García Sebastiani, Marcela (2005). Los antiperonistas en la Argentina peronista. Radicales y socialistas en la política argentina entre 1943 y 1951. Buenos Aires, Prometeo. Camarero, Hernán y Herrera, Carlos (2005). El Partido Socialista en Argentina: Sociedad, política e ideas a través de un siglo. Buenos Aires, Prometeo. Tcach, César (2003). La invención del peronismo en el interior del país. Santa Fe, Secretaría de Extensión, Universidad Nacional del Litoral.

${ }^{21}$ Scott, Joan (1990). "El género: una categoría útil para el análisis histórico", en Amelang, J. y Nash, M. Historia y género. Las mujeres en la Europa moderna y contemporánea. Alfons el Magnànim, València.

22 Acha, Omar y Quiroga, Nicolás (2009). "La normalización del primer peronismo en la historiografía argentina reciente", en EIAL: Estudios Interdisciplinarios de America Latina y el Caribe, $\mathrm{N}^{\mathrm{o}} 20,7-34$.

${ }^{23}$ Sobre las antinomias y el peronismo: García Sebastiani, Marcela (2005). Los antiperonistas..., op. cit. Fiorucci, Flavia (2004). "¿Aliados o enemigos? Los intelectuales en los gobiernos de Vargas y Perón", en E.I.A.L. Estudios interdisciplinarios de América Latina y el Caribe, 15 (2). Fiorucci, Flavia (2011). Intelectuales y peronismo: 1945-1955. Editorial Biblos. Sigal, Silvia (2002). 
previas, de más largo plazo, son ignorados o solamente se identifican como "etapa previa" o posterior al peronismo. La cuestión que nos proponemos analizar necesita imponer sus propias periodizaciones o, por lo menos, cargar las antiguas de nuevos significados, en el sentido que las estrategias organizativas, las acciones colectivas e individuales de los libertarios que actúan en las controversias con el peronismo, comienzan a gestarse y tienen continuidad con las experiencias de la década anterior, a partir de 1930 .

Pero el desafío de esta investigación no concluye en la visibilización de sujetos invisibilizados. Más bien, redoblaremos la apuesta al pensar este problema (que pretende ser historiográfico) desde nuevas perspectivas epistemológicas emparentadas con la sociología, la antropología y la filosofía. La novedad del abordaje no implica solamente incorporar nuevos autores, contemporáneos a la escritura de esta tesis, sino también construir una metodología propia, al entrecruzar estas perspectivas con la de los estudios de género y los de la historia política. Para comprender la dinámica del entrecruzamiento propuesto, quiero recordar aquí que las formas de abordaje de los sujetos de nuestra historia, se inscribe en dos planos. Un primer plano, que es el del análisis de las acciones de sujetos cuya identidad política coincide en el anarquismo; las trayectorias biográficas así como las conformaciones colectivas son los objetos de nuestro estudio. En un segundo plano, intentamos avanzar sobre las acciones llevadas a cabo por estos sujetos para enrolar a otros "sujetos" en su colectivo identitario, con el eje en la oposición al gobierno peronista: Obreros, universitarios, y mujeres representan los sujetos sobre los que se disputan sentidos, identificaciones e interpretaciones. Las perspectivas definidas nos facilitan el análisis de estos dos planos, y las mismas se articulan en cada capítulo con otras perspectivas y abordajes específicos.

En nuestra investigación, señalamos que los procesos de configuración del anarquismo sufrieron transformaciones en algunos aspectos en el período anterior al peronismo y que en el contexto de los dos primeros gobiernos de Perón, algunas continuaron y se reforzaron y otros, se modificaron. Es por ello que partiremos de pensar al colectivo libertario durante el peronismo como a un actor cuya identidad

"Intelectuales y peronismo", en Juan Carlos Torre (coord.) Nueva Historia Argentina. Los años peronistas (1943-1955), T. VIII, Buenos Aires, Sudamericana. Torres, Juan Carlos (1990). "La vieja guardia sindical y perón.” en Sobre los orígenes del peronismo. Buenos Aires, Sudamericana. 
se encuentra en curso de negociación, por lo que también identificaremos a los actores con los que sostiene las controversias partiendo de sus propias definiciones.

\section{Una apuesta metodológica}

La elección de la metodología que describiremos aquí es resultado de un proceso de búsqueda y descubrimiento de nuevas perspectivas. En anteriores oportunidades he abordado el problema planteado aquí desde diversas perspectivas como la de los movimientos sociales según las categorías de Sydney Tarrow ${ }^{24}$ o la de los campos, el hábitus y las trayectorias según Pierre Bourdieu. ${ }^{25}$

No obstante, los aportes de la sociología de la crítica, o "sociologías pragmáticas" me han permitido observar las acciones de los sujetos y los fenómenos a abordar desde una perspectiva dialógica, situada y compleja y es la que privilegio en esta investigación. ${ }^{26}$ Dentro de la diversidad de autores y perspectivas de estas nuevas sociologías, cuyas máximas referencias son Luc Boltanski y Bruno Latour, propongo abordar la complejidad de la construcción de una controversia partiendo de la operacionalización del concepto elaborada por Michel Callon. Este autor, junto con Bruno Latour, han elaborado lo que se denomina "sociología de la ciencia". ${ }^{27}$ Partiendo del estudio de situaciones

\footnotetext{
${ }^{24}$ Tarrow, Sidney (2004). El poder en movimiento: los movimientos sociales, la acción colectiva y la política. Alianza editorial.

${ }^{25}$ Bourdieu, Pierre (2005). "La ilusión biográfica" en Archipiélago: Cuadernos de crítica de la cultura, $\mathrm{N}^{\circ}$ 69, 87-96. Bourdieu, Pierre (1991). "Estructuras, habitus, prácticas", en El sentido práctico, Madrid, Taurus

${ }^{26}$ Gabriel Nardacchione, referente local en los estudios de las sociologías pragmáticas, resume de la siguiente manera los orígenes e influencias en los que se apoyan estas perspectivas: "La sociología pragmática irrumpe en el paisaje de las ciencias sociales francesas en la década de 1980. Una de sus aristas apunta a profundizar la simetría entre el conocimiento científico y el saber práctico u ordinario. En este sentido, y dentro del marco de una apertura de la sociología francesa al pensamiento anglosajón, recibe influencias tanto de la etnometodología como del pragmatismo americano." Nardacchione, Gabriel (2011). "Reflexiones sobre la sociología de la ciencia de Bruno Latour y la sociología política de Luc Boltanski" en Lecturas en debate: apuntes de investigación del CECyP, Año XIV, Nº 19.

${ }^{27}$ Citamos aquí los trabajos más importantes de Latour y Callon: Latour, Bruno (1983). "Give me a Laboratory and I Will Raise the Worl”, en Knorr-Cetina, Karim y Michael Mulkay (eds.), Science Observed: Perspectives on the Social Study of Science, Londres, Sage, 141-170. Latour, Bruno (1995). La vida en el laboratorio: la construcción de los hechos científicos. Madrid, Anaya. Latour, Bruno (2008). Reensamblar lo social: una introducción a la teoría del actor-red. Buenos Aires, Manantial. Latour, Bruno (1993). Nunca fuimos: ensayo de antropología moderna. Editorial Debate. Callon, Michelle (1986). The sociology of an actor-network: The case of the electric vehicle. Mapping the dynamics of science and technology, 23. Callon, M. , y Latour, B. (1981). "Unscrewing the big Leviathan: how actors macro-structure reality and how sociologists help them to do so.", en AAVV, Advances in social theory and methodology: toward an integration of
} 
complejas en las cuales los sujetos actuantes son tanto humanos como no humanos (elaborando por ejemplo, la etnografía de un laboratorio) ambos autores construyen una herramienta de análisis muy valiosa y aplicable también a la complejidad del mundo social. Corcuff resume esta perspectiva en dos componentes fundamentales:

"El principio de imparcialidad (...) ante el éxito o el fracaso de las construcciones cientificas estudiadas (...), lo que significa que "al analizar una controversia, no se debe privilegiar de entrada el enfoque que tradicionalmente se considera "vencedor o "verdadero". ${ }^{28}$

Frente al supuesto de que el peronismo había obturado cualquier intento de movilización opositora, y las acciones que ya hemos identificado llevó a cabo el colectivo libertario resulta más que iluminadora la posibilidad que nos brinda esta perspectiva de "poner en línea", en simetría, a los vencedores (¿el peronismo?) y los vencidos (¿el anarquismo?).

Según Callon, establecer una controversia implica, en primer lugar, no censurar a los actores cuando hablan de sí mismos o de su entorno social. Esto es, dar cuenta de las descripciones densas, cargadas de sentidos e interpretaciones de la realidad esgrimidas por los/las anarquistas. De esta manera, construiremos una "red de actores" en la cual podremos observar cada uno de los mismos tópicos y las relaciones que comienzan a establecerse entre ellos en una especie de plano o mapa en que los actores y discursos se ubican, siempre provisoriamente. En este caso, proponemos profundizar en los vínculos (controversias) que establece el movimiento libertario con el gobierno peronista, con el peronismo como movimiento de masas y con el Estado. ${ }^{29}$

El principio de simetría también implica no diferenciar entre el tipo de argumentos que el actor utiliza, sino explicarlos (traducirlos) utilizando un

microand macro-sociologies, 277-303. Callon, Michelle, y Latour, Bruno (1992). "Don't throw the baby out with the bath school! A reply to Collins and Yearley". Science as practice and culture.

${ }^{28}$ Corcuff, Philipe (1998). Las nuevas sociologías. Construcciones de la realidad social. Madrid, Alianza Editorial.

${ }^{29}$ Para el presente trabajo, hemos utilizado una traducción realizada por Juan Manuel Iranzo.

Publicado originalmente como Callon, Michelle (1986). "Some Elements of a Sociology of Translation: Domestication of theScallope and the Fishermen of St Brieuc Bay", en Law, J. (ed.) . Power, action and Belief: A New Sociology of Knowledge?, London, R.K.P. 
repertorio de traducción cuya elección pueda ser explicitada por el investigador. En este caso, intentaremos poner en el mismo plano de análisis aquellos argumentos que se utilizan para dar cuenta de una realidad percibida por los actores como tal y aquellos que circulan como opiniones o puntos de vista que refieren a la percepción en el plano de las ideas y que en general se traducen en forma de ideología.

La asociación libre es otro elemento que compone la perspectiva seleccionada y que en nuestra investigación implica que, en lugar de imponer una red de análisis pre-establecida sobre los sujetos y las acciones, el investigador sigue a los actores para identificar el modo en que éstos definen y asocian los distintos elementos mediante los que construyen y explican el mundo. En este momento de la investigación, el objetivo será desplegar todas las relaciones que se han establecido, considerando para ello tanto los discursos como las acciones de los actores sin diferenciar ambos planos.

En relación a este último punto, resta considerar una cuestión importante que hace a la especificidad de esta perspectiva y forma parte de una elección metodológica quizá controversial y discutible desde otras perspectivas: la no diferenciación entre discurso y acción. Si bien los primeros abordajes de este tipo se le atribuyen a Teun Van Dijk y el Análisis Crítico del Discurso, ${ }^{30}$ las versiones pragmáticas más radicales piensan los discursos como "actos de habla que performativamente producen eventos en el mundo". 32 En la presente investigación, esto implica que los discursos o los actos del habla, al ser públicos (y políticos en este caso), conforman una realidad, crean sentidos y construyen verdades. Trataremos de considerar las acciones y discursos de los actores/ sujetos actuantes en un mismo plano, esto es, describir las intervenciones (acciones y discursos) en la arena pública sin establecer jerarquías entre unas y otros. La palabra, hecha discurso, tiene el mismo valor que la acción.

Por otro lado, merecen una consideración diferenciada, los abordajes de la cuestión biográfica que realizaré en la presente investigación. Partiendo de la crítica de algunas perspectivas bourdieuanas, Bernard Lahire propone renovadas miradas sobre los caminos altamente transitados por la sociología crítica. ${ }^{33}$ Sin abandonar la

\footnotetext{
${ }^{30}$ Entre los innumerables aportes de Van Dijk, citamos a Van Dijk, Teun(2000). El discurso como interacción social: estudios del discurso, inroducción multidisciplinaria. Gedisa. Van Dijk, Teun (1980). "Algunas notas sobre la ideología y la teoría del discurso", en Semiosis, $N^{o} 5$ Jalapa, Mexico, 37-54. Sobre las perspectivas que subyacen en el Análisis Crítico del Discurso, ver Wodak, R., y Fairclough, N. (2000). "Análisis crítico del discurso", en AAVV. El discurso como 
idea de campo o trayectoria, profundiza en los problemas que estos presentan para el análisis de lo social, de las vidas de las personas. En primer lugar, resulta útil para esta investigación, el reconocimiento de que la idea de "campos" no incluye todos los espacios de socialización, como son la familia, el club o el espacio laboral: “(...) no toda interacción o situación social puede, efectivamente, asignarse a un campo. Los campos conciernen esencialmente al terreno de las actividades "profesionales" (y públicas). La teoría de los campos, no puede ser universal, sino que es una teoría regional del mundo social (...)". Traducido a nuestra investigación, son precisamente esos otros espacios, los de la sociabilidad cotidiana, familiar, de género, los que definirán los itinerarios individuales y colectivos del movimiento y los sujetos embanderados en el anarquismo así como también los debates y las acciones que sostienen con el peronismo. Por otro lado, es fundamental para el autor, considerar los momentos de quiebre, de elecciones personales, de catástrofes particulares, como momentos en que se cristalizan esas

interacción social: estudios del discurso, inroducción multidisciplinaria (pp. 367-404). Madrid, Gedisa. Wodak, R. (2003). "De qué trata el análisis crítico del discurso (ACD). Resumen de su historia, sus conceptos fundamentales y sus desarrollos”, en AAVV. Métodos de análisis crítico del discurso, $\mathrm{s} / \mathrm{d}$.

${ }^{32}$ Nardacchione, Gabriel (2011). "Reflexiones...”, op. cit. Pág. 172

${ }^{33}$ Bernard Lahire (1963) es un sociólogo francés, profesor de sociología en la École Normale Supérieure de Lyon y director del "Equipo de Provisiones, poderes, culturas, socialización" de Max Weber Centre (CNRS).

identidades e historias que componen al sujeto. ${ }^{31}$ Las situaciones reveladoras para el sujeto, son aquellas en que pasado y presentan representan identificaciones opuestas y ponen en tensión la pluralidad interna que lo componen: "En efecto, si el actor es el producto de una condición familiar homogénea y unívoca y de existencia $X y$, en el curso de su vida, sólo encuentra situaciones idénticas o análogas a $X$, pasado y presente, por consiguiente, no serán más que una sola cosa: ya no habrá diferencia alguna entre lo que el actor ha conocido

\footnotetext{
${ }^{31}$ Según Lahire, "Nuestra intención, en el plano teórico, es tomar en consideración el tema del pasado incorporado, de las experiencias socializadoras anteriores, evitando ignorar o anular el rol del presente (de la situación) como si todo nuestro pasado actuara "en bloque" en cada momento de nuestra acción, como si fuéramos en cada instante la síntesis de todo lo que hemos vivido anteriormente, y se tratara, en última instancia, de reconstruir esa sintesis, ese principio unificador, esa fórmula (mágica) generadora de todas nuestras prácticas." Lahire, Bernard (2004) El Hombre Plural. Los resortes de la acción. Barcelona, Bellaterra. Pág. 69.
} 
anteriormente y lo que conoce actualmente". ${ }^{32} \mathrm{Si}$ bien el autor no ha profundizado en la implementación de estos conceptos como herramientas metodológicas, operacionalizados como "pasos a seguir" en una investigación, nos interesa la propuesta en cuanto posibilidad de profundización en algunas problemáticas que la bibliografía existente sobre biografías, trayectorias o historias de vida no abordan. Es decir, nos permite pensar en los márgenes, en aquellos elementos de la vida de los sujetos que son dejados de lado en las narraciones o por parte de quienes recuperan sus figuras como personas destacadas en determinado ámbito o actividad.

En otro orden de cosas, en el desarrollo de esta investigación, tiene un lugar preponderante la acción en público. Ello significa analizar las estrategias, los intereses y las evaluaciones que los actores realizan en la arena pública, partiendo de las experiencias previas (individual y colectiva, privada y pública) y que determinarán sus elecciones. Siguiendo a Cefai, “(...) más que partir de estructuras económicas, sociales o políticas preconstituidas, o postular un tipo de racionalidad estratégica a priori para entender lo que sucede en una movilización colectiva hay que investigar sobre los contextos de experiencia de los actores." 33 Por otro lado, en nuestra investigación, más que centrarnos en el anarquismo como movimiento social, aspirando a vislumbrar el estatus de sujetos colectivos, " (...) la atención es desplazada hacia situaciones problemáticas. Intentando definirlas y controlarlas, diferentes actores se movilizan, entran en relaciones complejas de cooperación y de conflicto y configuran arenas públicas focalizadas en problemas públicos (...)" ${ }^{34}$ Estas perspectivas no rechazan de plano la categoría de movimiento social o de partido político como formas cristalizadas que contienen y determinan las acciones. Más bien, nos propone una manera renovada de evocarlos, pero “(...) a condición, primero, de identificar las ocurrencias y de tomar las significaciones en tanto que categoría práctica que organiza la experiencia de los actores. Segundo, no ceder a la ilusión de su unidad y de su identidad, sino que mostrar cómo se hace, concretamente, cómo se organiza, se unifica y se identifica en situaciones problemáticas por resolverse”. 35

\footnotetext{
${ }^{32}$ Ibíd. Pág. 70

33 Cefai, Daniel (2011), "Diez propuestas para el estudio de las movilizaciones colectivas. De la experiencia al compromiso" en Revista de Sociología, № 26, pp. 137-166.

34 Ibíd, pág. 140.

${ }^{35}$ Ibíd, pág. 142.
} 
Siguiendo los pasos enumerados por Callon, distinguiremos cuatro momentos de la traducción en los intentos del colectivo libertario por imponer (en el sentido de lograr consenso, realizar la identificación, no hay violencia en este momento) su definición de la situación sobre los demás actores, teniendo en cuenta para ello que en este proceso se negocian permanentemente la identidad de los actores, sus posibilidades de interacción y sus márgenes de maniobra:

1) Problematización: los libertarios, mediante la crítica al peronismo, tratan de resultar indispensables a las mujeres, los universitarios y los obreros, definiendo su naturaleza y sus problemas, y luego sugiriendo que éstos pueden resolverse si los actores negocian con la propuesta de cambio que presenta el movimiento libertario.

2) Interesamiento: una serie de procesos por los que los libertarios tratan de fijar a los otros actores en los roles que se les proponen en sus programas.

3) Enrolamiento: un conjunto de estrategias mediante las que los activistas libertarios buscan definir y relacionar los distintos roles que han asignado a los otros actores.

4) Movilización: un conjunto de métodos empleados por los libertarios para asegurarse de que los presuntos portavoces de los distintos colectivos que componen son capaces de representar a esos colectivos a los que apelan y no serán traicionados por ellos. ${ }^{36}$

Esta operacionalización nos permitirá avanzar en las controversias planteadas en tiempos del peronismo por los colectivos libertarios. Por otro lado, la propuesta apunta a "seguir a los actores", en cuanto a concentrarnos en sus propias interpretaciones de la realidad sobre la que intervienen. Nuestra función como investigadores-espectadores será la de desplegar las relaciones que se establecen en las controversias y realizar descripciones "complejas" y densas sobre esas redes.

De la mano de las particularidades de las biografías y las acciones colectivas que estas apreciaciones nos permiten visibilizar, la perspectiva de género es otra inflexión necesaria en nuestra investigación y la atraviesa de manera transversal.

\footnotetext{
${ }^{36}$ Callon, Michelle (1986). "Some elements...", op. cit. 
Intentaremos aquí establecer esas "redes" que unen y ponen en relación las perspectivas de las pragmáticas, la biografía desde el punto de vista de la sociología crítica y la perspectiva de género. Estas tres coordenadas serán los prismas a través de los cuales observaremos a el/los sujetos libertarios en los años y espacios que ya hemos delimitado.

Sin duda, la subjetividad de género junto a la heteronormatividad son componentes de la identidad aprehendidos pero fundamentales en la vida de las personas. Forma parte determinante de lo que Chiara Cerri llama subjetividades legitimadas: "El género es también parte de aquel espacio cognitivo/simbólico a través del cual el individuo (en posición continuamente instable) piensa a si mismo $y$ establece relaciones (continuamente fluidas) con las formas de identificación para sí y las formas de identificación para los demás. También es parte de aquel espacio de las prácticas sociales donde la persona es un agente social en constante e indeterminada relación con los demás y con las demás formas sociales." "37 Si bien la preeminencia en la conformación de las identidades según la autora, está en la identificación/socialización de género, se perciben similitudes en los planteos de los autores citados; fundamentalmente, en cuanto a la multiplicidad de identidades que componen al sujeto.

Estas elecciones metodológicas representan, en realidad, una propuesta abierta a nuevas reformulaciones y pensada como marco flexible en nuestra investigación. Siguiendo a Saltalamachia, consideramos que ello nos permite abrir dimensiones analíticas desde las que mirar el problema específico de nuestra investigación sin cercenar las posibilidades de conocimiento que se despliegan durante la misma dinámica del proceso en el que construimos el conocimiento. ${ }^{38}$

\section{EI corpus}

${ }^{37}$ Cerri, Chiara (2010) "La subjetividad del Género. El sujeto sexuado entre individualidad y colectividad", en Gazeta de Antropología, $\mathrm{N}^{\mathrm{o}} 26$. http://www.ugr.es/ pwlac/G26 42Chiara_Cerri.pdf)

${ }^{38}$ Saltalamacchia, H. (1997). "Los datos y su creación.", en Revista Kryteria. Puerto Rico. 
Párrafo especial merecen los comentarios acerca de las fuentes empleadas y los problemas para su abordaje. En primer lugar, debemos citar que las posibilidades reales para desarrollar esta tesis están directamente ligadas con la posibilidad de haber hallado fuentes escasamente tratadas hasta el momento. La totalidad de las fuentes primarias con las que hemos trabajado se encuentran en el Archivo que pertenece a la Biblioteca Anarquista de Estudios Libertarios (BAEL) de la Federación Libertaria Argentina (FLA), ubicado en el Barrio de Constitución, Buenos Aires. El relevamiento fue realizado entre los años 2008 y 2011. Este archivo se autogestiona y el espacio que ocupa también es sede para el encuentro de innumerables agrupaciones de tendencia anarquista. Desde el año 2012, se encuentra tomado por una de estas agrupaciones, lo cual ha dificultado el ingreso de estudiosos de la temática.

La producción periodística del anarquismo por excelencia en los años en que centraremos nuestro estudio (1946-1955) son los periódicos Reconstruir y Acción Libertaria (A.L.). Las colecciones incompletas las hemos hallado en el citado archivo, y hemos podido acceder a algunos números sueltos de ambos periódicos en la Biblioteca Popular José Ingenieros. Reconstruir es una publicación periódica cuyo primer ejemplar aparece en la primera quincena de junio de 1946. Se editan 90 números hasta junio de 1959, momento en el cual cambia y se convierte en revista, formato en que se publica hasta marzo de 1976. Si bien se gesta en el seno de la Federación Anarco-Comunista Argentina, no podemos asegurar que se trate de una publicación orgánica de dicha organización.

La heterogeneidad de las opiniones da cuenta de una apertura a opiniones incluso contradictorias dentro de las ideas anarquistas. También escriben allí algunos referentes socialistas y reciben la adhesión de un amplio abanico de organizaciones políticas no muy ligadas al ideario ácrata. A partir del año 1949, la escasez de papel para la prensa periódica (no oficialista o sin ligazones con el peronismo) así como también,el secuestro de las máquinas de imprenta e incluso la cárcel para los miembros de la editorial impiden que sea editado con regularidad. Acción Libertaria aparece como "Boletín del Comité Regional de Relaciones Anarquistas (CRRA)", bimestralmente pero con irregularidad, a partir de 1933. En 1936 cambia por el nombre de "Órgano de la Federación Anarco Comunista Argentina" (N 19, abril de 1936). El $\mathrm{N}^{\circ} 68$, de setiembre de 1943, comienza con el intento de sostener 
la regularidad quincenal, y cambia su denominación por el de “Órgano de la F.A.C.A.”, hasta setiembre del '45. En septiembre de 1946, en su número 94, se acompaña con la denominación de "Vocero de la Organización Anarquista

(F.A.C.A.)". Luego del No 142, de 1953, recién se retoma en el año 1955. El No 143 indica que es el “Órgano de la Federación Libertaria”. El último número es el 210, de marzo de 1971, luego de haber significado un esfuerzo para sus sostenedores por casi 4 décadas. ${ }^{39}$

Una tercera fuente de importancia en este trabajo es la Revista Americana de Educación (R.A.E.). Editada, dirigida y solventada por José María Lunazzi desde La Plata, aparece en 1946. Si bien el último Número (12) data de 1949, la revista tuvo una regularidad interrumpida: en algunas ocasiones fue mensual (en especial, los primeros 6 meses), mientras que en otras alcanzaba a publicarse con irregularidad cada 3 o 6 meses. $^{40}$ En el mismo archivo de F.L.A, hemos hallado numerosos documentos de la organización F.A.C.A. Entre ellos, cartas personales, temarios de asambleas, informes de los núcleos laquistas de gran cantidad de localidades y pueblos, folletos, etc.

La Biblioteca José Ingenieros y el CEDINCI también cuentan con algunos números sueltos de estas publicaciones y fueron consultados oportunamente en estos años de investigación. Comprobamos, también, la existencia de revistas culturales, políticas, literarias y educacionales de distintos puntos del país, que aunque en series discontinuas, en su conjunto pueden significar un corpus documental importante a través de los cuales es posible establecer líneas editoriales y planteos contextuales, las que serán empleadas en el presente trabajo como fuentes primarias. Entre las revistas que aparecen en éste período, podemos mencionar: Agitación, Ateneo, Avanzada, Boletín de los Universitarios Anarquistas, Luz, De pie, La Campana, Rebeldia, Unión Obrera Local de Mar del Plata, Unión Socialista Libertaria de Mar del plata. Este nivel de detalle advierte la existencia de un corpus documental profuso y accesible que hasta ahora no ha sido

\footnotetext{
${ }^{39}$ Sobre la descripción y características de A.L., remitimos al trabajo de López Trujillo, Fernando (2010). "Acción Libertaria. Órgano de la Federación Anarco-Comunista Argentina. Luego: de la Federación Libertaria Argentina (1933-1971) 1 1a Parte: 1933-1943”, en Publicaciones Periódicas Anarquistas (1925-1943). Publicaciones B.A.E.L (en cd room).

${ }^{40}$ La colección completa de la R.A.E. se encuentra disponible en la Biblioteca de la Facultad de Humanidades y Ciencias de la Educación de la Universidad Nacional de La Plata.
} 
indagado para el período en estudio. A pesar de la imposibilidad de acceder a las colecciones completas (tampoco podemos afirmar que hubiera más números publicados en la mayoría de los casos), estas revistas y boletines nos han permitido visibilizar colectivos, organizaciones, nombre y espacios diversos para el anarquismo local y del período estudiado.

\section{Sobre los capítulos}

La organización de los capítulos de la tesis responde a una lógica que se construye alrededor del problema de género que estructura nuestra lectura de los sujetos interpelados por el anarquismo. Siguiendo a Scott, entendemos que la perspectiva de género ha aportado a la historia la posibilidad de realizar nuevas preguntas, ampliar las perspectivas de análisis y permitir la elaboración de hipótesis que incluyan la perspectiva relacional de las vinculaciones sociales entre los sexos. ${ }^{41}$ En consonancia con lo anterior, y siguiendo los postulados críticos de la teoría feminista de que el universalismo abstracto en el que se inspira la teoría política no es sino la máscara tras la que se parapeta el "universal masculino", creemos que es precisamente esta forma de enunciar al individuo la que oculta en realidad las relaciones de dominación y desigualdad que históricamente se han dado en su nombre. Como ejemplo de esto, analizando la declaración de principios del periódico Reconstruir y Acción Libertaria según los criterios de Eliseo Verón sobre el discurso político, comprobamos que el "individuo" o sujeto prodestinatario es claramente masculino, no solamente porque está acompañado de elementos gramaticales (adjetivos y artículos) que refieren a lo masculino. ${ }^{42}$ El colectivo de identificación, el nosotros en el plano del enunciado es el colectivo "Reconstruir" y la F.A.C.A, como sostenedores de los periódicos y como colectivos de ideas. Al mismo tiempo, y más claramente, el colectivo de identificación negativo aparece como el nazifascismo, los gobiernos fuertes, las clases dominantes, las oligarquías, el Estado policíaco. Son numerosas las apelaciones a colectivos más abarcadores y amplios, en relación a los paradestinatarios y colocados en posición de recepción.

\footnotetext{
${ }^{41}$ Scott, Joan (1990). "El género...", op.cit.

${ }^{42}$ Verón, Eliseo (1987). "El discurso político" en La palabra adversativa. Observaciones sobre la enunciación política. Hachette ${ }^{46}$ Reconstruir, No 1 , junio de 1946
} 
Entidades, también enumerables, que designan colectivos: las masas de productores, los pueblos. Una característica de los discursos libertarios es, precisamente, utilizar numerosas estrategias metafóricas para nombrar y delimitar a sus enemigos, quizá como elemento estructural de la propia doctrina. Aquí, lo veremos profundizado por el marco en que se inscribe su propuesta de acción. Suponemos que es una estrategia para eludir directamente al régimen peronista y evadir la posibilidad de censura del nuevo proyecto editorial. Al mismo tiempo, la metáfora les permite ampliar la convocatoria a posibles nuevos adeptos a las ideas libertarias, no cerrando del todo la posibilidad a diversas interpretaciones por parte de los lectores. Pero "el sujeto" apelado siempre está masculinizado. ${ }^{46}$

La asimilación de los discursos existentes, siguiendo a Martín Rojo, no refiere a un solo origen: el individuo universal masculino se origina en los inicios mismos de la cultura escrita y se reformula en la modernidad con las teorías contractualistas. $^{43}$ Del mismo modo, desde su faz "ilustrada", las ideologías políticas de izquierda renuevan el cariz masculino del hombre-individuo revolucionario. El anarquismo resulta de un desprendimiento de ese tronco común de ideologías políticas de izquierda.

Se podría suponer entonces que, situándonos en la perspectiva de las eternas excluidas del discurso hegemónico, las mujeres, hallaríamos otras maneras de subjetivación y de discursividad con respecto a nombrar y nombrarse, y a identificar los problemas que los discursos hegemónicos niegan y que son la causa de su exclusión. Sin embargo, como veremos más adelante en nuestro análisis, precisamente esas estructuras discursivas anquilosadas son las que las siguen definiendo como colectivo.

¿Pudo el anarquismo, desde sus teorías radicales y críticas de la sociedad moderna liberal, escapar a esta forma de nombrar y concebir a su sujeto revolucionario? Partimos de considerar que lo femenino es invisibilizado en el "universal" masculino, desde lo enunciativo hasta las formas más claras y prácticas de ejercer la aparente igualdad. Pensar estas apreciaciones en términos de contradicción niega la posibilidad de un análisis más profundo, en términos de lo planteado por la sociología pragmática. "Siguiendo a los actores", veremos más

\footnotetext{
${ }^{43}$ Martín Rojo, Luisa (1997) "El orden social de los discursos", en Discursos, No 22. Sobre el contractualismo y la perspectiva de género, ver Pateman, Carol (1995). El contrato sexual. Madrid, Editorial Átropos.
} 
bien que la coyuntura obliga a estos colectivos a reescribir y reinterpretar las categorías y conceptos que forman parte del núcleo más duro de su ideología. No siempre se logra una coherencia entre esos planteos más dogmáticos y las necesidades de un discurso que "debe ser" amplio, inteligible y adaptado al momento en que se enuncia.

En ese sentido, queremos destacar que los capítulos se explican en función de captar a los sujetos masculinos representados por los obreros y los intelectuales incluyendo en tal categoría a profesionales y universitarios-, por un lado, y a las mujeres, por otro lado.

Como afirma Michelle Perrot, un análisis de los documentos desde el punto de vista del género, es el primer paso para una nueva escritura que necesita la historia dando lugar al reconocimiento de las acciones de mujeres, pero en ese camino, y no menos cierto, la de los varones. En uno de sus últimos trabajos, la autora, en un lenguaje autobiográfico, recorre los derroteros por los cuales la historia de las mujeres se ha convertido en la historia de las relaciones de género:

"La historia de las mujeres cambió. En sus objetos de estudio, en sus puntos de vista. Empezó por una historia del cuerpo y de los roles privados para llegar a una historia de las mujeres en el espacio público de la ciudad, del trabajo, de la política de la guerra, de la creación. Empezó por una historia de las mujeres víctimas para llegar a una historia de las mujeres activas, en las múltiples interacciones que originan los cambios. Empezó por una historia de las mujeres para convertirse más precisamente en una historia del género, que insiste sobre las relaciones entre los sexos e integra la masculinidad. Expandió sus perspectivas espaciales, religiosas y culturales". 44

Si bien no es una historia solo de las mujeres anarquistas o de las inflexiones de género en los dispositivos y alocuciones de los colectivos anarquistas, sí

\footnotetext{
${ }^{44}$ Perrot, Michelle (2009). Mi historia de las mujeres. Buenos Aires, Fondo Cultura Económica. Pág. 8.
} 
pretende abordar a los sujetos desde una perspectiva generizada. Entonces, profundizando en los modos en los que el género toma consistencia en los cuerpos y las mentalidades,

"las concepciones culturales de lo masculino y lo femenino como dos categorías complementarias aunque mutuamente excluyentes en las que los seres humanos están ubicados, constituye en cada cultura un sistema de género, un sistema simbólico o sistema de significados que correlaciona el sexo con contenidos culturales de acuerdo con valores sociales y jerarquías. A pesar de que los significados cambien en cada cultura, un sistema sexo-género está siempre intimamente interconectado en cada sociedad con factores políticos $y$ económicos". 45

El desarrollo de cada uno de los capítulos que sigue contiene y se estructura en base a estas nociones generales. Del mismo modo, cada capítulo presenta un problema metodológico e historiográfico complejo, en los cuales la especificidad temática y las apuestas teóricas serán desplegadas en profundidad.

El primer capítulo propone una mirada de "mediano plazo" sobre las agencias colectivas anarquistas entre 1930 y 1946, focalizando en los tres sujetos sobre los que se construyen esas agencias y hacia los cuales están dirigidas las estrategias discursivas y de movilización: las mujeres, los obreros y los universitarios. Este capítulo está orientado a dar un marco para comprender las controversias que el anarquismo sostiene en tiempos del peronismo, precisamente en relación a la disputa que pretende sostener con el peronismo sobre los sujetos que también están siendo "convocados" por el peronismo. Podemos avizorar las estrategias diferenciadas en los repertorios de organización. Por un lado, encontramos las instituciones que el anarquismo fue configurando con el fin de organizar la acción encaminada hacia el cambio social en clave libertaria. Sería el caso de lo que se denomina una organización finalista en cuanto a que el objetivo de máxima era la subversión del orden social existente. El ejemplo de este modelo

\footnotetext{
${ }^{45}$ De Lauretis, Teresa (1996). "La tecnología del género", en Revista Mora, № 2.
} 
organizativo para los años de nuestro análisis es la FACA. Este tipo de institución fue una empresa de largo plazo que perduró durante el período analizado desde 1935 hasta 1954. También encontramos otros tipos de organizaciones, en general locales o con objetivos específicos, y que no trascienden en el tiempo una vez trascendida la coyuntura para la cual fueron elaboradas. Diferenciamos aquí no sólo el tipo de organización sino también los sujetos (generizados) a los que apela: las mujeres, los obreros y los sectores estudiantiles y universitarios. En el período estudiado, los espacios de organización "específicos” surgen en relación con las agrupaciones de ayuda a los republicanos de la Guerra Civil española (entre 1936 y 1940), en la reorganización del movimiento obrero (1940-1943) y la participación en los espacios universitarios (1944-1946). Estas estructuras organizativas -con los sujetos a los que compelen movilizar- serán luego fundamentales para comprender las propuestas de organización cultural y política frente al fenómeno peronistas (1946-1955). Con este capítulo, que podría leerse en paralelo con el capítulo 2, propongo que para comprender las apuestas que los colectivos libertarios llevan adelante a partir de 1946, es necesaria una perspectiva más amplia que incorpore no solamente el período que cronológicamente comprende "la previa" del peronismo sino que establezca una línea de continuidad pues es precisamente allí donde pueden comprenderse los debates, las acciones, la participación

internacional y las apuestas "nacionales" de estos colectivos.

El Capítulo 2 avanza sobre la "cuestión biográfica" y los itinerarios individuales y colectivos de quienes aparecen como los sostenedores, propagandistas, organizadores y referentes del anarquismo en los años de nuestro estudio: Jacobo Maguid, José Grunfeld, José María Lunazzi, Juan Lazarte, Ana Piacenza, Herminia Brumana e Iris Pavón. Si bien esta selección es arbitraria, puesto que muchos referentes y militantes anarquistas son observables en las fuentes también en una actitud persistentemente combativa y organizadora y han quedado excluídos de la presente investigación, pretendemos abordarlos/las los perfiles aún no explorados de estas personas en relación al anarquismo. Un repaso por los orígenes familiares, la socialización política y de género, el ingreso a la política y al espacio público, así como también su participación política orgánica entre los comienzos de la década del 30 y los años 50 repasan en paralelo cuestiones colectivas, no solamente de las organizaciones que sostienen sino también de los discursos que atraviesan los imaginarios sociales más amplios que los/las contienen. Nuestro objetivo, al abordar las biografías, no es el de enumerar 
las características del colectivo anarquista a partir de la suma de las individualidades de sus sostenedores sino, más bien, explicar la heterogeneidad de las experiencias de quienes se movilizaron políticamente tras la bandera anarquista. Sin duda, en tiempos en que el anarquismo pierde la masividad del apoyo entre los sectores populares, las individualidades de quienes organizan y sostienen el movimiento tiene un lugar primordial para explicar su historia entre los años de nuestro estudio. Pero la vida de aquellos y aquellas anarquistas, de quienes veremos desplegar sus acciones durante los años del primer peronismo, no comienza ni acaba en sus experiencias de acción política y/ o pública. Es allí, en la diversidad de las experiencias, marcadas por su origen social y de género, en donde veremos desplegar sus biografías.

En el Capítulo 3, en particular, nos interesa analizar las opiniones de las anarquistas que participaron en el periódico Reconstruir acerca de la cuestión del voto y de la ciudadanía política femenina, nociones inseparables del modo en que el movimiento consideró a las mujeres. En los primeros números aparecía Herminia Brumana como editora de la página de la mujer, y parece haber sido también quien escribía las notas no firmadas. A partir de los últimos números de 1947, la página dedicada a las mujeres aparecerá de manera intermitente y se irá convirtiendo en escasos recuadros sobre temas relacionados con la actualidad política. Considerando el período 1946-1952, la última referencia a la mujer aparece en el número inmediatamente posterior a las elecciones del año 1951. A los vaivenes de la participación femenina y de la temática "mujeres" en el periódico debemos sumarle el gran problema que implicaba pertenecer a la prensa opositora al gobierno peronista. Esto incluyó tanto escasez de papel como secuestro de las máquinas de imprenta, e incluso la cárcel para los miembros de la editorial. De todos modos, aunque podamos atribuirle a Reconstruir una adscripción claramente "anarquista" en sus postulados fundamentales, es posible también ver allí las diferentes vertientes en que el movimiento se dirimió durante los años que tomamos para nuestro análisis. Las posiciones esgrimidas por las mujeres que adhirieron al ideario anarco-comunista a través del periódico Reconstruir se enmarcan en un campo de disputa por el poder, que en este caso se da en el plano discursivo, y que construye a "la mujer" como sujeto social por el cual se dirime la disputa hegemónica. Retomaremos la noción de "repertorio discursivo" que considera a las maneras en las que los contendientes (en este caso, las anarquistas frente al 
movimiento y al Estado peronista) articulan colectivamente la moralidad de sus reclamos y de las soluciones, así como su visión más amplia de lo social. ${ }^{46}$ Esta noción nos permite analizar de qué manera Reconstruir logra la legitimidad de su discurso sobre el voto y la ciudadanía política de las mujeres por medio de este mecanismo de apropiación-reformulación de los repertorios discursivos que circulan en la sociedad $\mathrm{y}$, particularmente, en confrontación con las ideas y acciones del peronismo. Para ello, antes especificaremos el discurso peronista respecto de ciertos tópicos y las discusiones historiográficas que se han dado en torno a ellos, para luego abordar el modo en que se analizan desde Reconstruir. Las tensiones y diferencias que percibimos en torno a esta cuestión $-\mathrm{y}$ que creemos tienen que ver con la naturaleza de la militancia y las ideas ácratas- nos permitirán trazar un itinerario de trayectorias individuales en ocasiones, y colectivas en otras, dinámica que atraviesa la totalidad de esta investigación. Nos interesa, finalmente, visibilizar a aquellas mujeres que tuvieron un rol fundamental tanto en el periódico como en su amplia y heterogénea participación durante los años del peronismo a través de sus percepciones y apuestas políticas: Herminia Brumana, Ana Piacenza e Iris Pavón.

El Capítulo 4 compone la segunda parte de lo que podría denominarse como una "trilogía" en cuanto a que aborda al segundo de los sujetos interpelados por el anarquismo y disputado por el peronismo: los obreros. Nos proponemos analizar la apuesta pública de los libertarios, nucleados fundamentalmente en la FACA, su periódico Acción Libertaria y en el grupo editor Reconstruir con el fin de apelar/disputar con el peronismo a los "obreros-trabajadores" como

\footnotetext{
${ }^{46}$ Seguimos lo planteado por Steinberg, cuyas ideas al mismo tiempo se enmarcan en lo que se ha dado en llamar "sociología norteamericana". El autor asegura que "[...] mediante estos repertorios discursivos, los contendientes articulan colectivamente la moralidad de sus reclamos y de las soluciones, así como su visión más amplia de la equidad social". La existencia de regularidades discursivas entre los contendientes no implica acuerdos "totales" entre las individualidades que los constituyen, sino que es precisamente la tensión constante la que dinamiza y les permite redefinirse frente al poder hegemónico que es el que impone la agenda, también cambiante y contradictoria. Es precisamente la relación entre estos repertorios discursivos y los repertorios de acción colectiva en que, según el autor, se define la comunidad de intereses. Así podemos observar que, si bien hay diferentes opiniones respecto de algunos temas (en especial en relación con la adscripción anarquista al feminismo), es en la acción (en este caso representada en el funcionamiento de la editorial Reconstruir y su intervención social a través del periódico) en que se refuerza la identidad del colectivo y la legalidad de sus demandas. Steinberg, RUDOLPH (1999) "El rugir de la multitud: repertorios discursivos y repertorios de acción colectiva de los hiladores de seda de Spitalfield, en el Londres del siglo XIX", en Auyero, Javier, Caja de herramientas. El lugar de la cultura en la sociología norteamericana, Buenos Aires, Editorial de la Universidad Nacional de Quilmes
} 
herramientas para la resistencia a la dominación de este "gobierno totalitario", tratando de vislumbrar allí las características del género que constituyen a ese sujeto obrero. Partiendo de una crítica generalizada a las estrategias sindicales y de movilización de los trabajadores llevadas a cabo por el peronismo, así como del modelo sindical propuesto por éste, el anarquismo retoma estrategias como la huelga general y la solidaridad con las causas de trabajadores no alineados con el Estado. La cuestión obrera ocupará la mayor parte del espacio del periódico orgánico de la FACA, mientras que sólo una página de Reconstruir será dedicada a las noticias del mundo obrero a partir de sus números iniciales. Un elemento que caracterizará las apreciaciones libertarias que veremos en estos dos periódicos, a partir de 1945, es la mención al peronismo cada vez que refieran al movimiento obrero. Como veremos, la aparición del mismo en la escena política y sindical representa para el anarquismo la posibilidad y el desafío de elaborar discursos y estrategias políticas concretas sobre la cuestión obrera. A partir de este momento, hablar del movimiento obrero significa hablar también del peronismo, sin olvidar que la apelación al obrero no refiere a una definición clasista del mundo, sino porque para el anarquismo es el más fiel representante de la explotación capitalista.

El Capítulo 5 refiere a tres sujetos que en tiempos de apelación a sectores no solamente obreros, el anarquismo vislumbra como posibles hermanos en la lucha y en la resistencia al peronismo: los profesores universitarios ligados a los ámbitos de la intelectualidad progresista y de izquierda, los científicos y los estudiantes. Intentaremos avanzar sobre las descripciones, interpretaciones y acciones que llevaron a cabo los colectivos libertarios para interpretar, interpelar y enrolar a estos tres sujetos (masculinos) en la lucha por "la idea" en tiempos del "fascismo criollo". El triunfo de Perón representó para la FACA la implantación definitiva del fascismo en el país, pero ya no como fenómeno aislado sostenido por un grupo de militares aduladores del clero -como habían evaluado al gobierno anterior-, sino con un fuerte anclaje y aprobación popular. Sobre este reconocimiento del anclaje popular del peronismo, el colectivo libertario pensará la clave para las nuevas estrategias organizativas y los proyectos culturales. En este caso, debemos diferenciar tres tipos de "repertorios", partiendo de considerar las individualidades y particularidades de los/las anarquistas que sostienen en estos años las agencias libertarias en relación al sujeto universitario-científicoestudiantil. En primer lugar encontramos aquellos que orgánicamente responden a FACA, cuyo mensaje se alinea claramente con los ideales libertarios y cuyos discursos están dirigidos a un 
público ligado a una cultura política de izquierdas y de tradición antifascista. Son los casos de Reconstruir, Acción Libertaria y las USL. En segundo lugar, identificamos y agrupamos a aquellas publicaciones y repertorios organizacionales que, aunque impulsadas y sostenidas por militantes referentes del socialismo libertario y del mundo universitario, su leit motiv es la defensa del "reformismo" en la universidad. Encontramos en este segundo grupo a la Revista Americana de Educación (R.A.E.), la Federación de Agrupaciones para la Defensa y Progreso de la universidad Democrática y Autónoma y la Alianza Laica Argentina (A.L.A.). En tercer lugar ubicamos a los grupos, movimientos y organizaciones que con una historia previa a la llegada del peronismo y alejadas del ideario libertario, comienzan a partir de este momento a ser impulsadas y defendidas por los anarquistas por el solo hecho de manifestar su oposición a las políticas educativas implementadas por el gobierno peronista. El motivo de este apoyo será simplemente la actitud combativa y la militancia antiperonista. Encontramos en este grupo a la Federación Universitaria de la Argentina (FUA), la

Federación Universitaria de La Plata (FULP), la Federación Universitaria de Buenos Aires (FUBA), la Asociación de Maestros y un amplio abanico de organismos ligados a la enseñanza, la cultura y la intelectualidad a lo largo y ancho de la Argentina. Si bien esta dimensión, en cuanto a las diferencias en los repertorios que hemos enumerado, estará presente en nuestro análisis, el mismo se vertebrará en torno a varios ejes. Estos ejes, que metodológicamente diferenciaremos en el plano del discurso y sobre los que se desplegarán las controversias, son la clave para comprender en qué medida el anarquismo disputará sujetos con el peronismo en torno a la cuestión educativa, cultural e intelectual: la autonomía y la democracia universitaria, la movilización estudiantil y las agrupaciones de científicos e intelectuales como forma de combatir al peronismo y el establecimiento de una "cultura dirigida" y de la enseñanza religiosa en las escuelas.

Las consideraciones finales tiene la estructura de un capítulo, puesto que pensado precisamente como un capítulo integrador en el que intentaremos abordar las "respuestas" no solamente de los sujetos a los que el anarquismo intentó movilizar, sino también las del gobierno peronista, el "otro" negativo frente al que se plantean los desafíos organizativos del movimiento libertario. También describiremos aquí los avatares de los colectivos y biografías de los libertarios en los años en que por diferentes factores y causas, la amplitud de las apuestas se ven reducidas no sólo en cantidad, sino también en los esquemas ideológicos sobre los que construyen el movimiento. 
Resta un breve comentario sobre los "para qué" de este trabajo de investigación. En primer lugar, nuestra pretensión es significar un nexo entre los estudios de la historia política, el peronismo, el anarquismo y las miradas generizadas sobre la historia en general. En segundo lugar, la visibilización de estas acciones propone ampliar el espectro geográfico y temporal en el que se desplazan las agencias libertarias. Posiblemente, resultan ser aspiraciones

"federalistas" que no sólo movilizaron a nuestros sujetos, sino que también motivaron esta mirada no centrada en el mundo capitalino. Si bien no ha sido posible aún reconstruir la totalidad de las agencias organizativas ni biográficas de las ciudades en que hemos anclado nuestro recorte, sí resulta accesible (a la luz de esta investigación) dibujar un mapa en el que, estableciendo puntos de actividad fijos y persistentes en el tiempo de la mano de las ideas anarquistas, se traza un itinerario o recorrido posible en el que fluyen y circulan ideas, personas y organizaciones entre ciudades como La Plata, Rosario, Mar del Plata y también Buenos Aires. 


\section{Capítulo 1}

\section{SUJETOS, ACCIONES Y ORGANIZACIÓN DEL ANARQUISMO, 1930-1945}

La historia del anarquismo en la Argentina remonta sus orígenes a las últimas dos décadas del Siglo XIX, momento en que son recepcionadas con énfasis las corrientes de pensamiento europeas que proponen una alternativa al sistema capitalista. Junto al socialismo, las ideas anarquistas serán motivadoras de las primeras formas de organización obrera y tendrán un fuerte protagonismo en las luchas contra la explotación en el mundo del trabajo, pero también una influencia definitiva en los círculos culturales e intelectuales sostenidos por escritores, filósofos, docentes y ensayistas que adhieren a la causa ácrata. Sin duda, en Argentina, el paradigma de las ideas y de la organización anarquista es la Federación Obrera Regional de la Argentina (FORA), que desde 1901 aparece con el nombre de Federación Obrera Argentina (FOA). Desde allí se promueve la acción directa a través de la huelga general y la organización en sociedades de resistencia, uniones obreras y federaciones de trabajadores. Estos serán, a su vez, los modelos de organización social para la nueva sociedad libertaria. La lucha que plantean es contra el capitalismo, pero también contra toda forma de explotación por lo que, la elevación cultural y espiritual del trabajador es tan importante como la lucha por la subsistencia:

"El Cuarto congreso de la F.O.A declara que ésta debe dirigir todos sus esfuerzos a conseguir la completa emancipación del proletariado, creando sociedades de resistencia, federaciones de oficios afines, federaciones locales, consolidando la nacional, para que así, procediendo de lo simple a lo compuesto, ampliando los horizontes estrechos en que hasta hoy han vivido los productores, dándoles a éstos más pan, más pensamiento, más vida, podamos formar con los explotados de todas la naciones la gran confederación de todos los productores de la Tierra, y así solidarizados podamos marchar, 
firmes y decididos, a la conquista de la emancipación económica y social". 47

Sin embargo, esa organización temprana no ocultó la significativa multiplicidad de orientaciones que tuvo el anarquismo rioplatense.

En resumen, identificamos el anarco comunismo como fundamento ideológico y conceptual de la organización colectiva para el anarquismo en los orígenes de la FORA pero también en los de la FACA.

Planteada esta introducción, y reconociendo la persistencia de una organización tan importante como lo fue la FORA, nos proponemos rastrear los repertorios organizacionales que embanderan el anarquismo entre 1935 y 1943. Es fundamental pensar estas agencias en el mediano plazo que precede al momento clásicamente conocido como "primer peronismo", para comprender la complejidad de estas estrategias y su presencia en una cultura política de las izquierdas que se perfila en los años 30 .

Podemos avizorar estrategias diferenciadas en los repertorios de organización. Por un lado, encontramos las instituciones que el anarquismo fue configurando con el fin de organizar la acción encaminada hacia el cambio social en clave libertaria. Sería el caso de lo que se denomina una organización finalista en cuanto a que el objetivo de máxima era la subversión del orden social existente. El ejemplo de este modelo organizativo para los años de nuestro análisis es la FACA. Este tipo de institución fue una empresa de largo plazo que perduró durante el período analizado desde 1935 hasta 1954, cuando cambia su nombre por el de Federación Libertaria (el cual mantiene hasta la actualidad). Pero también encontramos otros tipos de organizaciones, en general locales o con objetivos específicos, y que no trascienden en el tiempo una vez trascendida la coyuntura para la cual fueron elaboradas. Diferenciaremos no sólo el tipo de organización sino también a los sujetos (generizados) a los que apelan: las mujeres, los obreros y los sectores estudiantiles y universitarios. En el período estudiado, los espacios de organización "específicos" surgen en relación con las agrupaciones de ayuda a los

\footnotetext{
47 "Pacto de Solidaridad aprobado por la FORA, 1904", citado en Diego Abad de Santillán (200). La FORA. Ideología y trayectoria del movimiento obrero revolucionario en la Argentina. Buenos Aires, Libros de Anarres. Pág. 124.
} 
republicanos en torno de la Guerra Civil española (entre 1936 y 1940), en la reorganización del movimiento obrero (1940-1943) y la participación en los espacios universitarios (1944-1946). Estas estructuras organizativas -con los sujetos a los que compelen movilizar- serán luego fundamentales para comprender las propuestas de organización cultural y política frente al fenómeno peronistas (1946-1955). Nuestro trabajo se enriquecerá si tenemos en cuenta que cada uno de estos espacios organizacionales se despliega sobre ciertos ámbitos geográficos en particular. Ello requiere ampliar el análisis del anarquismo más allá de las fronteras impuestas por la historiografía que ha tendido a concentrarse en el fenómeno urbano, puntualmente la ciudad de Buenos Aires. Siguiendo con los planteos de las sociologías pragmáticas, las nociones de grupos $\mathrm{o}$ agrupamientos que describiremos, refieren directamente a las maneras en que los actores se autodefinen y denominan a las mismas. Según Latour, siempre hay "voceros" en los grupos, quienes se encargan de definirlos y marcar las fronteras con "lo otro":

"Para delinear un grupo, sin importar que tiene que ser creado desde cero o simplemente actualizado, tiene que haber voceros que hablen a favor de" la existencia del grupo, voceros que a veces hablan mucho. No importa qué ejemplo se tome (...), todos necesitan personas que definan lo que son, lo que deberían ser, lo que han sido. Estas personas trabajan constantemente, justificando la existencia del grupo, invocando reglas precedentes (...). Ningún grupo existe sin algún tipo de encargado de reclutamiento (...)", ${ }^{48}$

En el sentido de la cita, creemos que las acciones individuales, o de unos pocos, pueden explicar muchas veces los orígenes de los agrupamientos, las dinámicas internas de las organizaciones así como también los debates sucedidos hacia el interior de las mismas de acuerdo a algunas personalidades que estructuran, organizan y sostienen las acciones colectivas. Es por eso que el presente capítulo tiene estrecha relación con las biografías desplegadas a partir del capítulo 2 del presente trabajo.

\footnotetext{
48 Latour, Bruno (2008). Reensamblar lo social. Una introducción a la teoría del actor-red. Manantial, Buenos Aires. Pág. 53.
} 


\section{La fundación de la FACA}

La fundación de la Federación Anarco Comunista Argentina (FACA) en el año 1935 resulta una referencia inevitable para pensar las agencias ácratas entre los años 1946 a 1955 puesto que, como veremos, será la base sobre la que se construirán las posteriores intervenciones públicas y políticas en el ámbito nacional e internacional (durante la Guerra Civil en España y de la mano de los movimientos antifascistas) del anarquismo.

En este apartado, nos proponemos analizar el proceso que lleva a la fundación de la Federación Anarco Comunista Argentina como organización que nuclea a la mayor parte del movimiento libertario a partir de $1935 \mathrm{y}$, al mismo tiempo, pensar en la creación de organismos para la solidaridad con el pueblo español como parte de las estrategias de intervención política de más corto plazo (las que se crean con un objetivo o frente a una situación específica concreta y luego se diluyen).

La creación de la Federación Anarco Comunista Argentina (FACA) en el año 1935, representó un cambio en las estrategias organizativas en relación a la historia del anarquismo en la Argentina. Los militantes anarquistas Jacobo Maguid y José Grunfeld hablan de una intencionalidad en la construcción de un movimiento que comenzara por reconocer los desaciertos que habían llevado a su crisis (fundamentalmente las diferencias internas) y de la necesidad de establecer una nueva agenda en el escenario posterior al golpe militar de 1930:

"La dictadura quebró el poderio de sindicatos y núcleos hasta entonces considerados casi imbatibles. Había que prepararse para reiniciar la actividad en un futuro cercano. Así fue como (...) preparamos y realizamos una serie de reuniones, con un temario muy amplio, con relatores sobre cada tema, con debates y acuerdos bien precisos", 49

\footnotetext{
${ }^{49}$ Jacinto Cimazo (1995). Recuerdos de un libertario. Buenos Aires, Editorial Reconstuir. Pág. 26 
Asimismo, ellos coinciden en que se hizo necesaria una reflexión sobre el papel que habían cumplido las diferencias internas en ese deterioro y, se propuso tomar en cuenta los puntos de unidad más que los de desacuerdo. Así,

"se soslayó el forismo, el protestismo, el antorchismo, etc., que antes dividian, buscando coincidencias para un trabajo en común. Las experiencias anteriores valían, pero era vital desechar lo negativo y actualizar métodos". 50

A partir de allí, se proponían establecer una nueva agenda en el escenario posterior al golpe militar de 1930. Los temas centrales a tratar en esta nueva etapa serían: "El movimiento obrero, los medios de propaganda, los problemas del campo, las iniciativas populares, la educación, el aporte de la juventud". 51

A partir del año 1932, y como parte de las resoluciones del Segundo Congreso Regional Anarquista, comenzó a debatirse profundamente acerca de la necesidad de la creación de una "organización" que nucleara a las diferentes vertientes en que se manifiesta el colectivo. Cuando en 1935 se realizó en La Plata el Congreso en el que se constituye la FACA, las diferencias ideológicas y organizativas serán tema permanentemente de debate. Las voces que se expresan allí provienen, fundamentalmente, de alguna región o ciudad del país con tradición previa de militancia lo que posibilita establecer la persistencia de núcleos de acción anarquista anteriores al golpe militar de 1930, con antelación a la propuesta que se viene a llevar a cabo. ${ }^{52}$ Por un lado, algunos delegados representan instancias de organización nuclear que aparecen con el nombre de comités de zona, comités de relaciones o comité regional $\mathrm{y}$, también, se registran agrupaciones simplemente numeradas. $^{53}$

\footnotetext{
${ }^{50}$ Ibídem

${ }^{51}$ Ibídem.

${ }^{52}$ Por ejemplo, ciudades como Capital Federal, La Plata, Rosario, Bahía Blanca, Mar del Plata, pero también localidades más pequeñas como Pergamino, General Pico y Tandil entre otras.

53 Aparecen con el nombre de comités de zona, comités de relaciones o comité regional. También, agrupaciones numeradas pero diferenciadas por localidad, lo que indica cierta organicidad o por lo menos esfuerzos previos por parte de las personas convocantes a este congreso. Jacinto Cimazo refiere a la "incansable" labor de los militantes a lo largo y ancho del país entre los años 1932 y
} 
Asimismo, figuran otras agrupaciones como las sociedades de resistencia o los grupos culturales tales como las Asociaciones de las Juventudes Libertarias. ${ }^{54}$

La intención de estructurar una organización de militantes libertarios fue uno de los puntos más ampliamente discutidos en el Congreso en el cual la heterogeneidad de agrupaciones participantes fue la nota peculiar y requirió de formas más precisas de integración a la FACA. Según López Trujillo, muchos delegados objetaron la incorporación a la organización de las Juventudes Libertarias y también se opusieron a la participación de los colectivos de mujeres, asociaciones antiguerreras y estudiantiles, que si bien no formaron parte del congreso, tendrían participación en el movimiento libertario de los próximos años. El rechazo se fundamentó en el entendimiento de que los objetivos de estas agrupaciones representarían "desviaciones" de la lucha general y total contra el capitalismo. Sin embargo, las agrupaciones por "afinidad" (las más antiguas) eran mucho menos numerosas que las nuevas y la intención de quienes promovieron la organización del Congreso había sido - precisamente- ampliar la capacidad de inserción del movimiento y no limitarse a los tradicionales núcleos de actividad anarquista como fueron las antiguas sociedades de resistencia.

La idea de una organización única para todos los anarquistas parece surgir como una necesidad coyuntural para combatir la tiranía del gobierno "de facto" y reformular la actuación como fuerza política. Los términos bajo los cuales ejercerá esta participación serán ampliamente discutidos en este congreso constitutivo. Por un lado, la FACA no realizará acciones conjuntas con ningún partido político ni participará en los frentes populares, es decir, la participación conjunta con fines electorales de dos o más fuerzas o partidos políticos. ${ }^{55}$ No obstante, dejará abierta

1935, para lograr un mínimo de organización necesaria y así acudir al congreso fundacional de la nueva (y primera) organización libertaria.

${ }^{54}$ Éstas son producto de un fenómeno organizativo que nace en España en el año 1932 y es adaptado por algunos grupos de jóvenes anarquistas locales. Las Juventudes Libertarias (J. J. L. L. en Argentina) tendrán una amplia participación a lo largo de los años de nuestro estudio. Aparecen en este Congreso fundacional de la FACA en 1935 y también las vemos participando junto a las Uniones Socialistas Libertarias en la oposición al peronismo. En el año 1939, por ejemplo, desde las páginas de su publicación, llaman a la realización de su primer congreso nacional, piden por los compañeros presos, apoyan la "revolución social" encarada desde los cuadros obreros revolucionarios y llaman a la educación y capacitación de todos los militantes. J.J.L.L. de Argentina (1939). Boletín de las Juventudes Libertarias, $\mathrm{N}^{\circ} 3$. Buenos Aires, octubre.

${ }^{55}$ En el caso del Partido Comunista, a partir de 1935, propone la participación en estos frentes como estrategia en la lucha antifascista. Camarero, Hernán (2007). A la conquista de la clase obrera. Los 
esta posibilidad a los frentes de masas. La diferencia entre los primeros y los segundos parece haber radicado en que los frentes populares fueron vistos como organizaciones que respondían a los partidos políticos tradicionales, mientras que los frentes de masas no se ajustaban a esa modalidad de participación. La FACA pivoteará, entonces, entre estas dos posibilidades de acción y dejará a criterio de las agrupaciones que la integren, la participación conjunta con otras fuerzas políticas.

Los fundamentos sobre los que el anarquismo aspira a construir su propuesta revolucionaria tienen como objetivo de máxima la "insurrección de las masas oprimidas, la expropiación de los capitalistas y la destrucción del estado". $60 \mathrm{El}$ nuevo régimen social se basará en los sindicatos de oficio, de industria, campesinos, comunas, cooperativas y consejos, evitando en la nueva construcción la imposición de cualquier tipo de centralidad y de jerarquía política. Una estructura federativa es la que aparece como modelo de organización frente al de las jerarquías de los partidos tradicionales de izquierda. ${ }^{61}$

En líneas generales, en los años 30, la FACA apuesta por ampliar el sujeto al que interpela el anarquismo. Ya no serán solamente el obrero o el pobre, sino que aspira a convertirse en portavoz tanto de aquellos como de intelectuales, profesionales, estudiantes, mujeres y todos aquellos que se opongan a la tiranía y al fascismo. Debemos reconocer que esta orientación del anarquismo tiene una clave doctrinal y no responde solamente al devenir histórico político argentino, en cuanto a que la apelación no fue nunca directa y exclusivamente al obrero; aunque según el momento puede quedar subsumida en esa relación. Suriano marca que:

\section{“(...) para la constitución del sujeto social, la doctrina libertaria ponía énfasis no en determinadas relaciones con los medios de}

contra el fascismo en 1936, junto a radicales, comunistas, socialistas y la CGT. Pero terminaron por separarse cuando los anarquistas entendieron que había una intencionalidad política en los partícipes que no era la que los convocaba. Sin embargo, una actitud más amigable con respecto al "frentismo" correrá a cargo de las Juventudes Libertarias (que en Córdoba impulsan la creación de una Alianza Juvenil Proletaria con la Juventud Socialista, la Juventud Socialista Obrera y la Juventud Comunista. López Trujillo, Fernando (2005). Vidas en rojo y negro..., op. cit.

comunistas y el mundo del trabajo en la Argentina, 1920-1935. Buenos Aires, Siglo XXI. Por otro lado, López Trujillo afirma que la FACA apoyó la creación de un frente popular 
${ }^{60}$ En las Resoluciones del Congreso constitutivo de la FACA, citado por López Trujillo. López Trujillo, Fernando (2005). Vidas en rojo y negro..., op. cit., pág. $249{ }^{61}$ López Trujillo, Fernando (2005). Vidas en rojo y negro..., op. cit.

producción sino en las formas de la opresión. (El anarquismo) poseía, en términos generales, una dimensión moralista y universalista que la llevaba a superar la perspectiva de clases e interpretar el fenómeno capitalista en términos diferentes al marxismo [...]; la causa de la división social no se hallaba sólo en el régimen de propiedad y salarios, sino también en la enorme distancia cultural entre los sectores sociales". 56

A continuación, nos interesa analizar el modo en que la FACA encaró esa convocatoria a distintos sujetos en el nuevo contexto y las propuestas específicas que se plasmaron con ello.

\section{Las mujeres como sujetos movilizados}

Como lo adelantamos en la Introducción, los debates historiográficos sobre las mujeres en el anarquismo argentino comienzan tras la veta iniciada por Dora Barrancos. Varias investigaciones han retomado la temática de las mujeres anarquistas, subrayando las interpretaciones particularísimas de las anarquistas en relación a la ciudadanía sexual, la beligerancia de sus demandas tanto dentro como fuera del movimiento y las empresas culturales y políticas que llevaron adelante pensadas como producciones de y para mujeres. ${ }^{57}$ La reconstrucción de los

\footnotetext{
${ }^{56}$ Suriano, Juan (2002). "En defensa de los oprimidos: el anarquismo y la formación de una cultura de izquierda en la Argentina", en Prismas. Revista de historia intelectual. № 6. Pág. 167

${ }^{57}$ Barrancos, Dora (1990b) “Anarquismo y sexualidad”, en Armus, Diego (comp.), Mundo urbano y cultura popular, Buenos Aires, Sudamericana. Barrancos, Dora (1996) "Mujeres de Nuestra Tribuna: el dificil oficio de la diferencia", en Mora. Revista del Área Interdisciplinaria de Estudios de la Mujer, $\mathrm{N}^{\circ}$ 2, 1996. Barrancos, Dora (1990a). Anarquismo, educación y costumbres en la Argentina de principios de siglo, Buenos Aires, Contrapunto. Lobarto, Mirta Zaida (2007) Historia de las trabajadoras en la Argentina (1869-1960), Buenos Aires, Edhasa. Guzzo, Cristina (2003).

Las anarquistas rioplatenses, USA, Orbis Press. Feijoo, María del Cármen (1990). "Las trabajadoras porteñas", en Armus, Diego (comp.). Mundo urbano y cultura popular, Buenos Aires, Sudamericana. Bellucci, Mabel y Camusso, Cristina (1987) "La huelga de inquilinos de 1907. El papel de las mujeres anarquistas en la lucha", en Cuadernos del CICSO, serie Estudios, $\mathrm{N}^{\circ} 58$. Bellucci, Mabel (1990). "Anarquismo, sexualidad y emancipación femenina. Argentina alrededor
} 
itinerarios de vida de varias militantes ácratas ha tenido un impulso en los últimos años. $^{58}$

Según esta bibliografía, en los anarquismos de esta primera época existen críticas a la familia y el matrimonio que se engarzan con el rechazo de la hipocresía de la vida sexual en la sociedad capitalista y de la familia tradicional como instrumento de control social y esclavitud de las mujeres. Estas cuestiones han sido abordadas en sintonía con el análisis de Barrancos, pincelando el quehacer feminista en las agencias femeninas dentro de las corrientes anarquistas. Mabel Bellucci destaca el estatus supremo de mujer-compañera al que apela la ética libertaria en el contexto histórico de comienzos de siglo en la Argentina: avanza en torno a algunos planteos del anarquismo local como las uniones libres, los métodos contracepcionales, la abolición de la prostitución y la maternidad idealizada y responsable. La autora relaciona las ideas de las libertarias sobre la mujer y su sexualidad en línea con el feminismo de los años 60 y caracteriza a las libertarias por su "pionerismo", como antecedente del "feminismo resultante" de los años $60 .^{59}$ En este caso, se evidencia un anacronismo que postula al anarquismo como una etapa del feminismo que contradice toda postura asumida por el movimiento ácrata en relación con el feminismo.

El concepto de anarco-feminismo presente en varios trabajos es también problemático. Critina Guzzo habla de "la irrupción del discurso anarco feminista" aludiendo a las agencias anarquistas que exceden el plano puramente político. ${ }^{66}$ Igual que en Bellucci, el germen feminista aparece en las anarquistas de principios de siglo como "la libertad de amar; la honestidad en las relaciones intersexuales, dentro y fuera de la familia; el cuestionamiento del matrimonio como un contrato opresivo capitalista; el cuestionamiento de la familia tradicional como célula

del 900", en Nueva Sociedad, N 109, septiembre-octubre. Bacci, Claudia y Fernández Cordero (2007). "Feroces de lengua y pluma. Sobre algunas escrituras de mujeres anarquistas", en Políticas de la Memoria, núm. 6/7.

${ }^{58}$ Queirolo, Graciela (2010) "Herminia C. Brumana. La maternidad social a través del magisterio y de la escritura", en Adriana Valobra (ed.), Mujeres en espacios bonaerenses, Buenos Aires, EDULP.

Saítta, Sylvia (1995). “Anarquismo, teosofía y sexualidad: Salvadora Medina Onrubia”, en Mora. Revista del Área Interdisciplinaria de Estudios de la Mujer, № 1. Saítta, Sylvia (1998). Regueros de tinta. El diario Crítica en la década de 1920, Buenos Aires, Sudamericana. Fletcher, Lea (1987) Una mujer llamada Herminia, Buenos Aires, Catálogos.

${ }^{59}$ Bellucci, Mabel (1990) “Anarquismo, sexualidad...”, op. cit., pág. $155^{66}$

Guzzo, Cristina (2003) Las Anarquistas..., op. cit. 
autoritaria; el adueñamiento del cuerpo, el derecho al placer y el control de la natalidad". ${ }^{60}$ Nuevamente, la enumeración de las características componentes de esta supuesta "rama" del anarquismo, dan cuenta de las cuestiones relevantes para la agenda del feminismo de los años $60^{\prime}$. Incluso, la autora plantea una matriz original única para todo el arco del feminismo "histórico" de fines del siglo XIX y $\mathrm{XX}$, del cual el anarco-feminismo fue una forma particular en la sociedad rioplatense como "anarco feminismo <latino>, caracterizado por el incuestionable valor de la maternidad". ${ }^{61}$ En esa línea, Molineaux considera que la historia de dominación colonial y regímenes políticos excluyentes y patriarcales, conllevó que las mujeres desplegaran el lenguaje de la diferencia utilizado "para descalificarlas de la ciudadanía política y de la igualdad legal" y lo resignificaran, llevando las virtudes femeninas de la casa al espacio público. ${ }^{62}$

Otra caracterización de las agencias de las ácratas en clave feminista la brinda precisamente Molineux quien habla del "feminismo anarquista" como una tendencia particular dentro del anarquismo argentino, al analizar el periódico $L A$ Voz de la Mujer. ${ }^{63}$ La importancia de este periódico y la necesidad del conocimiento de su existencia para el movimiento feminista latinoamericano, proviene del hecho de que aparece como una publicación completamente hecha por mujeres, para mujeres y en clave "feminista", según la autora. Al mismo tiempo, representa el accionar de un tipo de feminismo no ligado al de "las burguesas", sino obrerista y revolucionario. La especificidad feminista en la teoría anarquista, según la autora, aparece en la crítica al matrimonio y la denuncia de la dominación masculina, aunque, con el paso de los números, se percibe que el feminismo se va perdiendo en pos de la ortodoxia anarquista. Molineux "adscribe" a las redactoras del periódico al feminismo y sentencia su fracaso por la "ferocidad" de una escritura demasiado insurgente en relación con las mujeres a las que intenta agenciar. A lo largo del texto, la categoría "feminismo" no se enmarca en una

\footnotetext{
${ }^{60}$ Ibídem, Pág. 7.

${ }^{61}$ Ibídem, Pág. 32

62 Molineux, Maxine (2001). “Género y ciudadanía en América Latina: cuestiones históricas y contemporáneas", en Debate feminista. Año 12, Vol. 23, México.

${ }^{63}$ Molyneux, Maxine (1997) "Ni dios ni patrón ni marido. Feminismo anarquista en la Argentina del siglo XIX”, en La Voz de la mujer. Periódico Comunista-Anárquico. 1896-1897, Buenos Aires, Universidad Nacional de Quilmes
} 
opción metodológica que operacionalice el término, sino que lo toma como idea general de un "feminismo" resultante difícil de identificar analíticamente.

Hasta aquí, hemos visto cómo diversas acepciones del término "feminismo" permearon los análisis sobre las agencias de mujeres y la cuestión femenina en las corrientes ácratas locales. Por un lado, existen evidentes conexiones teóricas y prácticas entre el anarquismo y las agrupaciones feministas de la segunda ola. Pero allí no debería agotarse el balance, puesto que interesa profundizar en cuáles son las categorías que están en juego para recrear la construcción histórica. Asimismo, se percibe en la bibliografía una creencia respecto de que cualquier movimiento $u$ organización de mujeres puede ser caracterizada como feminista, lo que creemos que no es el caso de las anarquistas. Si bien las vemos movilizadas, sus voces apelan a que no se las confunda con las posturas feministas, y menos aún, con las sufragistas. Así, existiría un "sentido común" en los estudios feministas sobre la historia de las mujeres que muchas veces obtura la posibilidad de analizar la heterogeneidad y riqueza de las acciones de mujeres en cada momento histórico.

Dora Barrancos enfatizó la particularidad y la importancia de "la cuestión femenina" en la cultura anarquista. ${ }^{64}$ Afirmó que hasta la década del '20, los discursos anarquistas se estructuran, mayoritariamente, desde el lugar "esclarecido" del hombre. Allí es hegemónica la percepción masculina sobre la liberación de la mujer. Para la autora, en el anarquismo de estos años, prima la mirada masculina, aunque reconoce la particularidad de la organización de las mujeres en torno al periódico La Voz de la Mujer. Sus 9 números aparecen en el espacio rioplatense entre 1896 y 1897, teniendo como principal portavoz a Virginia Bolten. El mensaje de este medio era dirigido -generalmente- a la mujer obrera, a las mujeres de extracción popular y -en general- era leído por las mujeres de la colectividad española e italiana. Para Barrancos, "la mujer" como instrumento fundamental y medio para la liberación es un aspecto hegemónico dentro del anarquismo de ese período. Las dificultades de este grupo de mujeres proletarias, entre las que se pueden enumerar la persecución policial, la falta de recursos y de apoyo de sus compañeros anarquistas, no opacan la importancia que esta publicación tuvo para la historia del anarquismo ya que fue única en Latinoamérica para estos años. En los anarquismos de esta primera época existen críticas a la familia y al matrimonio que

${ }^{64}$ Barrancos, Dora (1991). Anarquismo..., op. cit. 
se engarzan con el rechazo de la hipocresía de la vida sexual en la sociedad capitalista y de la familia tradicional como instrumento de control social y esclavitud de las mujeres. ${ }^{65}$

Paralelamente a la experiencia de La Voz de la Mujer, aparecen en los principales centros urbanos los Centro Femeninos anarquistas. El objetivo de los mismos era sostener espacios culturales como bibliotecas o grupos de teatro, simultáneamente a la organización en los lugares de trabajo. ${ }^{6667}$

La aparición de Nuestra Tribuna, periódico quincenal impulsado por Juana Rouco desde Necochea, representa la segunda experiencia colectiva de mujeres anarquistas en la Argentina. La persecución policial, las constantes mudanzas y el abandono de su compañero con la consecuente carga económica y laboral para mantener a sus hijos sobre sus espaldas, no impidieron que la publicación apareciera durante 3 años (1922-1925) y tuviera, incluso, alcance internacional. ${ }^{68}$

Dora Barrancos analiza en este periódico escrito por y para mujeres, las relaciones y enfrentamientos intergenéricos con los compañeros de ideas y los intragenéricos con las feministas. ${ }^{75}$ A partir del análisis de las formaciones discursivas de Nuestra Tribuna, Barrancos identifica las reyertas con los compañeros anarquistas explícitas en el periódico y asegura que se trata de disputas por el poder doctrinario y comunicacional de la ideología aderezado con pujas internas. La crítica a las feministas que realizan las anarquistas, por otra parte, se apoya en las dimensiones públicas y no en la discusión sobre los métodos

\footnotetext{
${ }^{65}$ Barrancos, Dora (1991). Anarquismo..., op. cit.

${ }^{66}$ Manzoni y Ledesma Prietto mencionan a Bolten y Juana Rouco como fundadoras del primero de estos centros. La persistencia de este tipo de organización se extiende incluso hasta después de ${ }^{67}$. Ledesma Prietto, Nadia y Manzoni, Gisela (2010). "Pluma, Aguja y Barricadas: desafiando la hegemonía patriarcal", en Valobra, Adriana (edit.) Mujeres en espacios bonaerenses. La Plata, EDULP. Ello es documentado por López Trujillo , cuando al enumerar las organizaciones anarquistas que participan del Comité Regional de Relaciones Anarquistas en 1932, aparece en la lista el Centro Femenino "Luz en la Oscuridad" de Rosario representado por Francisca Benito. López Trujillo, Fernando (2005). Vidas en rojo y negro..., op. cit.

${ }^{68}$ Los 39 números que se han encontrado en el Archivo social de Ámsterdam, fueron editados con nota preliminar. Calzetta, Elsa (2005). "Juana Rouco Buela, una mujer anarquista", en Nuestra Tribuna. Hojita del sentir anárquico femenino (1922-1925), Bahía Blanca, EDIUNS. ${ }^{75}$ Barrancos, Dora (1996) "Mujeres de Nuestra Tribuna: el dificil oficio de la diferencia"..., op. cit.
} 
contracepcionales o los derechos sexuales, temas fundamentales para el anarquismo internacional en ese momento. ${ }^{69}$

Cabe recordar que estas experiencias colectivas de mujeres son paralelas a las de las organizaciones anarquistas "masculinas", fundamentalmente a la de la FORA. La década del 20 está marcada por los enfrentamientos internos entre los sostenedores de La Protesta (ligada a la FORA) y La Antorcha, en el que también las mujeres tomaron parte. Es conocida la participación de Juana Rouco en las filas de la FORA, así como también la pluma de Herminia Brumana colaborando en algunos números de La Antorcha.

Algunos hechos coyunturales locales, contemporáneos a la fundación de la FACA y la creación de esta organización específica, determinan la entrada de muchas mujeres al campo de la lucha política (muchas de la mano del anarquismo, otras en apoyo a causas puntuales tales como los comités pro presos o la ayuda a España). Una de estas experiencias es la movilización por la causa de los Presos de Bragado. El encarcelamiento de tres obreros de orientación anarquista (Pascual Vuotto, Santiago Mainini y Reclús De Diago), en 1931, acusados de un atentado en el que murieron la hija y la cuñada de José María Blanch (personaje político aliado al conservadurismo de la ciudad de Bragado), produce el inmediato repudio de todo el arco opositor al gobierno de facto y sus sectores aliados y se organizan los comités de ayuda, a partir de ese momento. En este marco se da el ingreso al campo político de un importante contingente femenino, entre las que en adelante también conformarán el colectivo libertario anarquista, como Ana Piacenza, Iris Pavón o Herminia Brumana. La campaña consistió en conseguir financiamiento para las familias de los presos, realizar actos y mítines en todo el país para dar a conocer la causa y sumar nuevos apoyos. Esta campaña convocó a participar políticamente a aquellos ya comprometidos con el movimiento libertario y a aquellas que se acercaban por primera vez a los ámbitos de participación política. Las condiciones generales de fuerte represión por parte del estado sobre los hombres ligados a una forma de ejercer la militancia y de relacionarse con los espacios de participación "tradicionales" de la cultura política de izquierda argentina habilitan la aparición de mujeres en espacios que, aunque limitados por estas formas tradicionales de

\footnotetext{
${ }^{69}$ Basta con citar a Amparo Poch, Lucía Saornil o Federica Montseny del anarquismo español de estos años. Remitimos al trabajo al trabajo de Andrés Granel, Elena (2006). "Mujeres Libres: emancipación femenina y revolución social”, en Germinal, Nㅜ 43.
} 
participación y organización políticas, actúan activamente y se incluyen en esos espacios "masculinos" por tradición.

Asimismo, el comienzo de la guerra civil en España, en 1936, implicó la participación de muchas de las mujeres, que ya para estos años, militaban activamente en la organización anarquista FACA. Ante los requerimientos de la Confederación Nacional de los Trabajadores (CNT) española y la Federación Anarquista Ibérica (FAI), la FACA tiene una participación viva y activa incluso con varios militantes libertarios en el frente y ocupando cargos de importancia en la península. ${ }^{70}$ Por otro lado, la FACA intervino en la formación de numerosos comités populares de Ayuda a España al mismo tiempo que fundó (siguiendo los criterios de la CNT y de la FAI), el Servicio de Propaganda de España e impulsó la formación de la Solidaridad Internacional Antifascista (SIA). ${ }^{71}$ En este marco, desde Cruz del Eje, Iris Pavón impulsa la creación de la Asociación Femenina Antiguerrera, y lo replican otras mujeres en otros puntos del país. Éste es un grupo femenino que, si bien no sólo está integrado por quienes comulgan con las ideas anarquistas, es impulsado por la prensa orgánica faquista "Acción Libertaria”." 72 Según dicho periódico, las acciones de esta agrupación de mujeres no se limitan a recaudar fondos o a funciones de asistencia al pueblo español, sino que participa activamente (puntualmente en el caso de Cruz del Eje) en la organización de mitines y reuniones políticas junto a otras organizaciones como sindicatos, uniones de trabajadores, bibliotecas, centros socialistas y agrupaciones libertarias.

Iris Pavón también actuó en el Comité de Ayuda al Pueblo Español, que de acuerdo a los registros de la SIA, fue durante un tiempo la responsable de ese organismo en la Argentina. Ana Piacenza, por su parte, participa en la publicación

\footnotetext{
${ }^{70}$ Jacobo Maguid recuerda en sus memorias a los compañeros de ideas que viajaron a España con el fin de unirse al frente republicano: José Grunfeld, Ana Piacenza, Jacobo Prince, Antonio Casanova, Pedro Di Césare, Laureano Riera, José María Lunazzi y otros. Puntualmente, la FACA nombra como delegados en España a Jacobo Prince, Jacobo Maguid y José Grunfeld, quienes ocuparon cargos de máxima responsabilidad en los diarios "Solidaridad Obrera", "Tierra y Libertad" y en las respectivas organizaciones CNT y FAI. Jacinto Cimazo (1995) Recuerdos de un libertario..., op. cit.

${ }^{71}$ López Trujillo, Fernando (2005). Vidas en rojo y negro..., op. cit.

${ }^{72}$ En su primer manifiesto, apela a un discurso que ensalza a la maternidad como estado natural de las mujeres: “(...) madres antes que mujeres; (...) como madres las llamamos y como madres las esperamos", así también como la importancia de estas para sostener al hombre que es quien desata las verdaderas batallas contra la opresión: "Somos las compañeras, las madres, las hijas de los eternos parias que en tiempos de paz llenan los talleres y las fábricas y en tiempos de guerra los mataderos que pomposamente se llaman "gloriosos campos de batalla". Pavón, Iris (1952). Pasión de Justicia. Buenos Aires, Editorial Reconstruir. Pág. 55.
} 
“Mujeres Libres", donde desarrollará una línea editorial e ideológica en pos del reconocimiento de las mujeres y sus especificidades como sujetos. Utilizando el seudónimo Nita Nahuel, publica en el primer número de Mujeres libres una crítica a los compañeros de ideas (anarquistas) que rechazan la participación de las mujeres en la lucha armada y pretenden tenerlas apartadas de los escenarios que su

"naturaleza" les imprime. En el mismo artículo, a partir de un hecho sucedido en una manifestación callejera (violencia verbal hacia una mujer anarquista), denuncia que tras algunas máscaras anarquistas se esconden espíritus fascistas. No aparece en su exposición la posibilidad de que un mismo compañero de ideas rechace la participación pública y política de las mujeres. Por el contrario, infiere una naturaleza solidaria de los hombres anarquistas con respecto a las luchas de las mujeres. La crítica no es hacia la humanidad masculina anarquista, Piacenza no considera al ideario anarquista como sostenedor de las desigualdades y exclusiones, sino que cree que existen quienes representan mal al colectivo ácrata:

“fascistas de pañuelo rojo y negro", 73 Mientras actúa allí, Ana Piacenza también será editora responsable de la publicación "Tierra y Libertad" y delegada de la FACA en el Grupo C de la FAI en Barcelona.

A pesar de la derrota en manos del ejército franquista, la experiencia española definió los caminos posteriores de las mujeres que representan al movimiento libertario en la Argentina. Éste estará delimitado por la lucha contra el fascismo (que inevitablemente se desplaza hacia el escenario argentino con el golpe militar de 1943 según la prensa libertaria) y la apelación a "las mujeres" como sujeto para el cambio social.

El ingreso de estas mujeres al anarquismo, su mayor participación y el proceso de reconocimiento como "políticas" de parte de sus compañeros, y por la sociedad en general, implicó que, a partir de 1943, el estado en manos del nuevo gobierno militar recayera sobre ellas con todo su aparato represor: su destino fue la cárcel. Hasta ese momento, el encarcelamiento había sido el método por excelencia para sosegar a la militancia política y social, mayormente de izquierda y

"masculina". Si bien no existen investigaciones que aborden puntualmente la situación de las presas políticas en los años de nuestro estudio, de alguna manera

\footnotetext{
${ }^{73}$ Nita Nahuel (1936) “Fascistas en rojo y negro”, en Mujeres Libres, № 1, pág. 12 
son conocidos los casos de mujeres militantes del Partido Comunista en la Argentina que pasaron por esa experiencia. Ana Piacenza fue presa en Rosario entre agosto de 1943 y octubre de 1944. Iris Pavón fue detenida durante 4 meses en la Cárcel de Mujeres del Buen Pastor de Córdoba, donde era la única presa política entre cientos de reclusas.

\section{Los trabajadores: sindicalismo y acción política}

Diego Abad de Santillán, histórico referente anarquista durante gran parte del Siglo XX, realiza un minucioso trabajo documental en relación a la Federación Obrera Regional de la Argentina (FORA), desde sus comienzos hasta $1930 .^{74}$ Allí, el autor puntualiza en la descripción de los sucesivos congresos y las huelgas generales llevadas a cabo por la organización anarquista y apunta sobre la necesidad de que el movimiento obrero anarquista avance en la revolución social, superando la etapa puramente sindical de reclamos por mejores condiciones laborales y de calidad de vida en tiempos de una fuerte represión estatal que ha obligado a Santillán a escribir desde la clandestinidad. También aprecia en su libro el problema que representa para el anarquismo la pérdida de adhesión que se viene dando desde mitad de la década del 10`. Ante esta situación, el autor propone ampliar las bases del anarquismo por fuera del mundo obrero, pero con él a la cabeza. Sebastián Marotta, cercano al sindicalismo revolucionario da cuenta de los debates y sucesos entre sindicalistas y anarquistas en estos mismos años. ${ }^{75}$ Esta

"historia" desde adentro aporta fundamentalmente información detallada y un gran corpus documental, pero ha sido descartada por la historiografía tradicional del movimiento obrero en la Argentina por su poca objetividad.

Por otro lado, desde la producción académica, son innumerables los autores que abordan la historia del movimiento obrero, para el que los anarquistas tuvieron

\footnotetext{
${ }^{74}$ Diego Abad de Santillán (2005). La F.O.R.A, op. cit.

${ }^{75}$ Marotta, Sebastián (1960). El movimiento sindical argentino. Su génesis y su desarrollo. Buenos Aires, Ediciones Lacio. Sobre Marotta y el sindicalismo revolucionario en la Argentina ver Belkin, Alejandro (2006). Sobre los orígenes del sindicalismo revolucionario en Argentina, Buenos Aires, Ediciones del Centro Cultural de la Cooperación Floreal Gorini.
} 
un papel fundacional y preeminente hasta la llegada del peronismo. Del Campo aborda el proceso por el cual el anarquismo, y la FORA en particular, pierde apoyo obrero, alrededor de la década del 10. El autor cree que los cambios en la estructura social y económica de los trabajadores provoca que sus reclamos no se orienten ya al cambio social y la revolución, si no a la mejora de sus condiciones laborales. ${ }^{76}$

Podemos identificar dos argumentos en torno a los cuales se ha legitimado la aseveración acerca de la desaparición del anarquismo entre las filas obreras entre 1910 y 1930, años en que la FORA pierde influencia en la clase obrera y en el mundo de las luchas sindicales: a) los cambios sociales y económicos que experimenta la Argentina entre fines del Siglo XIX y 1930 producen el alejamiento de las masas obreras del ideario y prácticas libertarias; ${ }^{77}$ b) la imposibilidad de conciliar intereses que existió entre las diversas tendencias del anarquismo en el Río de la Plata. ${ }^{78}$

López Trujillo ha visibilizado las estrategias de la FACA tendientes a organizar la lucha sindical partiendo de los sindicatos por industria. ${ }^{79}$ Por otro lado, Iñigo Carrera y Benyo analizan una de las facciones del movimiento ácrata que aparece a mediados de la década del 30': la Alianza Obrera Spartacus, cuyas acciones fueron fundamentales para visibilizar el amplio abanico de las orientaciones libertarias y sus formas específicas de organización. $^{80} \mathrm{La}$ participación de este grupo anarquista (alejado de la FORA y de la FACA por ciertos guiños marxistas según Benyo) en la gran Huelga de la construcción del año

\footnotetext{
${ }^{76}$ Del Campo, Hugo (1971). Los anarquistas, Buenos Aires, Centro Editor de América Latina.

${ }^{77}$ Así el sindicalismo (como ideología de la clase obrera) aparece en el escenario político y sindical atrayendo a esas masas obreras que ya no se sienten representadas por las ideas anarquistas: " $E l$ rechazo absoluto e intransigente de toda realidad social existente en nombre de una hermosa utopía, la protesta simbólica y violenta precursora del estallido revolucionario donde los oprimidos se jugarían a todo o nada, iban perdiendo entonces sus adeptos frente a quienes preferían dirigir sus energías hacia la conquista paulatina de mejores condiciones de vida y de trabajo". Del Campo, Hugo (1986) El sindicalismo revolucionario (1905-1945), Buenos Aires, Centro Editor de América Latina. Pág. 19-20.

${ }^{78}$ Este argumento lo encontramos especialmente en Etchenique, Jorge (2000). Pampa Libre..., op. cit. También Anapios, Luciana (2008) "Compañeros, adversarios y enemigos. Conflictos internos en el anarquismo argentino en la década del '20", en Entrepasados, N $\mathrm{N}^{\circ} 31$.

${ }^{79}$ López Trujillo, Fernando (2005). Vidas en rojo y negro..., op. cit.

80 Benyo, Javier (2005). La Alianza Obrera Spartacus. Anarquismo, vanguardia obrera e institucionalización del movimiento sindical en la década de 1930, Buenos Aires, Libros de

Anarres. Iñigo Carrera, Nicolás (2006). "Alternativas revolucionarias en los 30: la Alianza Obrera Spartacus y el Partido Socialista Obrero", en Biagini, Hugo y Arturo Roig, El pensamiento alternativo del Siglo XX, t. II, Buenos Aires, Biblos.
} 
1935 tampoco es referido en los trabajos que hablan del mundo obrero y sindical entre los 30 y hasta la llegada del peronismo. Precisamente son los estudios sobre los orígenes de la adhesión de la clase obrera al peronismo los que indagan acerca de la conformación de esas masas obreras y sus formas de organización política y sindical en los años que van de 1930 a 1943, para explicar la adhesión masiva de estos al peronismo. El tema ha generado uno de los debates historiográficos más importante en los últimos 30 años en la Argentina. Estos estudios dan por sentada la desaparición del anarquismo en el mundo obrero de la mano de la caída de la FORA como organización sindical que contenía a la mayoría trabajadora. Si bien coincidimos en la pérdida de adherentes con respecto al anarquismo forista, el problema de la relación entre el anarquismo y el mundo obrero en los años 30 no se agota en ello. Más bien, identificamos intenciones, acciones e intentos de organización en el mundo obrero por parte de los libertarios nucleados en la FACA. Es precisamente desde allí donde avizoramos intentos de renovación en las estrategias anarquistas con respecto a la movilización política y sindical en el mundo obrero.

Como resultado de las discusiones llevadas a cabo en el Segundo Congreso Ordinario de la FACA de 1940, se decidió la promoción de la organización obrera industrial. Los partícipes del Congreso creyeron percibir la existencia de grandes masas populares disponibles, descreídas políticamente y pasibles de ser "manipuladas" por cualquier partido político que tuviera un anclaje popular y en la clase media. En ese momento, la FACA consideró que esa posibilidad estaba representaba por el radicalismo (C.O.R.S, 1941). Frente a tal escenario, recomendaron la actuación de los militantes faquistas en los gremios autónomos (no ligados con las centrales sindicales ya nombradas), constituyendo uniones industriales y uniones obreras locales. ${ }^{81}$ Del mismo modo, y en clave de alianza político - sindical, crearon junto a la Unión Sindical Argentina (USA) la Comisión

\footnotetext{
${ }^{81}$ El caso de la creación de la Unión Obrera Local de Mar del Plata ha sido estudiada en Nieto, 2009. Allí el autor realiza un repaso por los conflictos obreros y sindicales, las reivindicaciones y los resultados obtenidos por estas nuevas formas de organización del anarquismo en el movimiento obrero. También da cuenta de las relaciones que se establecen con el resto de las fuerzas políticas y sindicales de izquierda en esa ciudad bonaerense.
} 
Obrera de Relaciones Sindicales (CORS) y el periódico Solidaridad Obrera como su órgano de propaganda. ${ }^{82}$

Laura Ruocco analiza para estos años la formación de la Unión Obrera Local que nucleó a la mayoría de los gremios autónomos de la ciudad portuaria y balnearia de Mar del Plata. Ésta se inscribió en una más amplia estrategia de intervención por parte del movimiento libertario: “(...) El anarquismo incorporó la organización de sindicatos industriales como práctica para adaptarse al movimiento obrero que se desarrollaba junto con la industrialización del país". ${ }^{83}$ No son pocas las referencias en las fuentes orgánicas en cuanto al crecimiento de las filas comunistas en el movimiento obrero y sindical, y es en relación a ello que aparecen nuevas propuestas para la actuación en el mismo sector. Podemos aventurar que existió una disputa por los mismos sujetos ya que, como veremos luego, se registró una situación similar en el movimiento estudiantil y universitario durante los años de la intervención a la universidad. ${ }^{84}$

La mirada y el análisis que la FACA realiza acerca de las condiciones actuales del movimiento obrero y la organización sindical, se inscriben dentro de lo que se ha denominado la "visión pesimista" sobre el sindicalismo y la democracia sindical. ${ }^{85}$ Los argumentos faquistas a favor de una actuación en conjunto con otros órganos y centrales sindicales (fundamentalmente la Unión Sindical Argentina, USA), se apoyan en la crítica a las formas tradicionales, hegemónicas y actuales en que se desenvuelve la acción sindical: "Estamos resueltamente contra el reformismo colaboracionista, contra la sumisión a las instituciones oficiales y a toda especie de politiquería dentro de las organizaciones". ${ }^{93}$

\footnotetext{
${ }^{82}$ La CORS está compuesta por un consejo de los cuales forman parte la Unión Obrera Local de La Plata, la Federación Obrera de la Madera, la Federación de construcciones navales, el Sindicato Único de Obreros de la Madera, el Sindicato de Obreros Plomeros, Cloaquistas y Anexos, el Sindicato de Colocadores de Mosaicos, todos representando a los sindicatos autónomos; junto a 3 delegados de la USA.

83 Ruocco, Laura (2009). "Mujeres obreras y sindicalismo anarquista. Dos paradigmas historiográficos”, en Revista de Historia Bonaerense, No 35. Pág. 67.

${ }^{84}$ Osvaldo Graciano analiza los acontecimientos y visualiza allí la actitud militante y de resistencia a la intervención primero del gobierno militar y luego del peronismo en el poder, de la mano de profesores como Rafael Grinfeld, José María Lunazzi y Aquiles Martínez Civelli en la Universidad Nacional de La Plata; todos reconocidos militantes libertarios en los años de nuestro análisis. Graciano, Osvaldo (2008). Entre la torre de marfil..., op. cit.

${ }^{85}$ Esta visión pesimista implica (fundamentalmente en las críticas desde la izquierda política), según Ghigliani, pensar que “(...), la burocracia y sus traiciones terminan explicando todos los
} 
La identificación de la CGT como central burocrática y aliancista con el gobierno de turno no es nueva en el repertorio discursivo del anarquismo. Sin embargo, resulta particular la caracterización que aquí se hace de "la política" inmiscuida en los asuntos de los trabajadores. Existiría una "mala" manera de hacer política que responde claramente a las acciones del Partido Comunista en los órganos sindicales y que representa "métodos stalinianos" de dirección, sujeción y control de las demandas obreras más "puras”. Según este discurso, los partidos obreristas (socialista y comunista),

\section{“(...) consideran a los sindicatos simplemente como organismos} auxiliares de su política, como base de reclutamiento electoral y a veces también como < vaca lechera $>$ para la financiación del aparato burocrático del partido". 94

Pero la crítica es siempre a las dirigencias, no al gremio ni a los trabajadores. Los trabajadores siempre se movilizan con objetivos de lucha genuinos. Y el ejemplo de manipulación de los intereses legítimos por parte de un partido político, es la Federación Obrera Nacional de la Construcción (con una conducción comunista). La Unión ferroviaria es el ejemplo del aliancismo con la CGT y de ésta con el gobierno de turno. ${ }^{95}$ Frente a este escenario pesimista, la

males de la clase trabajadora, mientras que la democratización del sindicato se convierte en el panacea para la movilización y la lucha, simplificaciones estas que descansan, con frecuencia, sobre una tajante separación entre las bases (y su pureza) y la dirigencia (y su corrupción)." Ghigliani, Pablo (2009) "Dilemas de la democracia sindical: la Federación Gráfica bonaerense", en Belkin, Alejandro (comp.) Relatos de lucha 1. Contribuciones a la historia del movimiento obrero. Asociación de Trabajadores del Subte.

${ }^{93}$ Acción Libertaria. $\mathrm{N}^{\mathrm{o}}$ 38, octubre de 1940, p.2

94 "En las organizaciones sindicales es funesto el tutelaje político", en $A . L ., \mathrm{N}^{\mathrm{o}} 39$, noviembre de 1940, pág 2 .

${ }^{95}$ Entre enero de 1940 y agosto de 1943, el periódico Acción Libertaria sale de manera casi ininterrumpida con una periodicidad mensual. En todos los números que hemos analizado, la crítica

creación de una nueva central sindical implica asimismo una política de alianzas con aquellos sectores sindicales no adheridos a estas dos corrientes principales y hegemónicas, y la USA representa para los faquistas esa posibilidad. La creación de la Comisión Obrera de Relaciones Sindicales (CORS) realizará, según la 
FACA, una tarea de "recuperación sindical". En la Conferencia Nacional de Sindicatos Autónomos, en febrero de 1941, de la cual surge la CORS, aparece la idea de "saneamiento sindical". Esta acción deberá ser ejercida desde diversos frentes por parte de la nueva agrupación sindical: en la

\begin{abstract}
“(...) la lucha contra las medidas restrictivas oficiales oposición abierta al código de trabajo proyectado, por considerarlo un intento reaccionario de trabar el libre desarrollo de las organizaciones sindicales; lucha por la generalización de la jornada de cuarenta horas como medio de resolver en parte el problema de la desocupación vinculación estrecha y permanente entre el proletariado industrial y el campesino a los efectos del necesario ejercicio de la solidaridad proletaria y el mejoramiento de las condiciones de vida y de trabajo de este ultimo". ${ }^{96}$
\end{abstract}

En su aplicación concreta, en febrero de 1941, la CORS propone declarar la huelga general por tiempo indeterminado, contra un decreto dictado por el gobernador de la Provincia de Buenos Aires en ese momento, Manuel Fresco. Según ese decreto, se limitaba el horario para el funcionamiento de las secretarías, no se concederían permisos para la realización de reuniones e se imponía la presencia de empleados policiales en ellas. En el mismo manifiesto, reclamaban el derecho a utilizar las plazas públicas, y pedían la derogación de la medida que

a estos dos sindicatos componen una sección fija del periódico. En la página 2 o 3 (según el número de la edición), los temas sindicales aparecen en torno a la crítica de lo actuado por estas dos corrientes políticas y su manipulación en clave sindical de los obreros. Para los laquistas, representan des formas de sindicalismo "mal entendido": "El primero se sitúa generalmente al margen de la realidad, confunde las fórmulas teóricas con los hechos reales, se lanza -verbalmentecontra molinos de viento y aleja de sus núcleos a la masa trabajadora que no comprende sus abstracciones ni sus fulminantes anatemas de tipo religioso. El segundo frena y esteriliza la acción, sin compensación alguna con la burguesía y el gobierno - cualquier clase de gobierno- evita y sabotea sistemáticamente todo lo que sea acción directa de los trabajadores organizados, convierte al sindicato obrero en un despreciable rodaje del aparato burocrático oficial. Prácticamente constituye una flagrante traición a los fines fundamentales de la organización proletaria(...)” A. L., $\mathrm{N}^{\circ} 40$, diciembre de 1940, P. 3

${ }^{96}$ A. L., $\mathrm{N}^{\circ} 41$ enero de 1941, p. 3.

impedía la circulación de la prensa obrera. ${ }^{86}$ Pero el escaso número de trabajadores que componen los sindicatos y uniones obreras en la CORS, imposibilitará que sus

${ }^{86}$ A. L., No 42, febrero de 1941, p. 2. 
acciones tengan algún tipo de repercusión. Esto, sumado a las diferencias políticas irreconciliables entre la FACA y la USA (en relación los fines a los que cada perseguía con la acción sindical) serán motivos para que a poco de fundada, comiencen los desentendimientos. Para los faquistas, la USA no cuenta con ningún tipo de aval como central obrera. ${ }^{87}$ Para febrero de 1943, según Acción Libertaria, el volumen de los trabajadores adheridos no alcanza para constituir una nueva central sindical, y aduciendo además diferencias políticas irreconciliables, la USA deja de formar parte de la CORS. ${ }^{88}$ En los meses que corren hasta el golpe de estado del mes de junio, los faquistas perciben la acción sindical de los gremios y sindicatos cegetistas así como las divisiones internas de la misma central como la causa del debilitamiento del sindicalismo y la pérdida de sus objetivos legítimos.

En agosto de 1943, la Ley de Asociaciones Profesionales (decreto 2669) implicará el golpe de gracia final para la CORS. El politólogo Luis Campos advierte que los efectos de esta norma fueron virtualmente nulos, en tanto su vigencia fue suspendida en diciembre de 1943, como consecuencia de un cambio en la orientación de la política sindical del gobierno militar, principalmente a partir de la asunción de Perón como titular del Departamento Nacional del Trabajo. ${ }^{89}$ Pero para la CORS significó la disolución. Entre las múltiples exigencias y condiciones que fija el decreto, para poder gozar de personería gremial, será condición esencial la exclusión de todo "postulado o ideología contrarios a los fundamentos de la nacionalidad y al régimen jurídico social que establece la constitución nacional". ${ }^{90}$ En segundo lugar, imponía que los miembros del sindicato tuvieran nacionalidad argentina o fueran naturalizados con 5 años de antigüedad. Por último, el departamento Nacional del Trabajo quedaba como árbitro exclusivo, controla todo lo relativo a contabilidad, movimiento de asociados, autoridades, etc. ${ }^{91}$ A todo ello se sumó el encarcelamiento de muchos militantes faquistas que participaban en la CORS, y la clausura de todas sus publicaciones.

\footnotetext{
${ }^{87}$ A. L, No 48 , septiembre de 1941 p. 2.

${ }^{88}$ A. L., $\mathrm{N}^{\mathrm{o}} 63$, marzo de 1943.

89 Campos, Luis (2009). "Estado y sindicatos: un análisis de sus relaciones a partir de los mecanismos de regulación y la conformación de la estructura sindical en Argentina (1943 - 1988)" (mimeo).

${ }_{91}^{90}$ A. L, N $\mathrm{N}^{\mathrm{0}}$ 67, agosto de 1943, p. 2.

${ }^{91}$ Ibídem.
} 
De acuerdo a lo analizado hasta aquí, para la FACA será central la organización obrera y las reivindicaciones laborales. Sin embargo no debemos perder de vista la idea de que el fin último era la lucha contra las fuerzas totalitarias, identificadas en "la oligarquía conservadora, los amos de la tierra, los beneficiarios de las instituciones de crédito, la clase vacuna por excelencia". ${ }^{92}$ Socialistas y comunistas son considerados como parte del mismo fenómeno totalitario. Así, la función de este movimiento obrero motorizado desde la FACA, entrelaza prácticas sindicales con reclamos y participación política en el plano nacional e internacional. ${ }^{93}$ Precisamente, su caracterización del totalitarismo como fuerza hegemónica e inevitable teñirá todas las manifestaciones de las organizaciones, desde los años de la guerra de España hasta bien entrados los 50, en sus análisis sobre el peronismo. En ese marco, la apelación a la resistencia que articula el anarquismo incluirá no sólo al movimiento obrero, sino que el llamado se amplía a vastos sectores sociales.

Según interpreta el anarquismo en ese momento, las crisis nacional y mundial son consecuencia de la debilidad estructural del capitalismo y de las democracias burguesas. ${ }^{94}$ Por ello, un "cuartelazo" al estilo nazi-fascista como el del 4 de junio parecía ser la consecuencia esperada en el marco nacional pues

\begin{abstract}
"Discípulos retardados del totalitarismo foráneo, imitan su estridente $y$ corruptora demagogia obrerista, su seudo anticapitalismo, su antiliberalismo efectivo, su discriminación racial. Incluso han incubado un grotesco imperialismo argentino, llevando la triste parodia hasta una tentativa de militarizar la nación (...). En el orden cultural y educacional han dado auge a un clericalismo desorbitado que pretende llevar al país a la época de la inquisición". 95
\end{abstract}

\footnotetext{
92 "Manifiesto al Proletariado del país". Comisión Obrera de Relaciones Sindicales. 1941, en López Trujillo, Fernando. Vidas en rojo y negro..., op. cit.

93 “Manifiesto al proletariado del país..., op. cit.

94 "Lucha constructiva por la libertad y la justicia social. Posición del movimiento libertario ante la actual situación mundial y argentina. Ediciones FACA, Buenos Aires, 1944.

${ }^{95}$ Ibídem, pág. 11.
} 
La amplitud del espectro sobre el que el fascismo criollo ejercía su poder, llevó a los faquistas a interpelar a todos aquellos que de una u otra manera lo sufrían.

Ahora bien, si la lectura de la coyuntura fragmenta las problemáticas, no es posible escindir ninguna de ellas del problema fundante del sistema a cuya solución de fondo hay que propender: "un régimen de convivencia sin privilegios, en que la administración de la riqueza social y del producto del trabajo, esté en manos de los propios productores, racionalmente organizados". 96

Según lo planteado por López Trujillo, a partir de 1943, se presenta una gran desarticulación de las estructuras faquistas dentro del movimiento obrero y sindical, bajo condiciones de fuerte represión y de pérdida de adhesión resultantes de las maniobras políticas del nuevo movimiento que se está gestando en el poder. Se percibe por primera vez una actitud gradualista en el movimiento libertario, en cuanto a no proponerse ya objetivos de máxima "revolucionarios", sino actuando puntualmente frente a algunos sucesos y promoviendo la solidaridad con todos aquellos que se opongan al fascismo nacional. Para López Trujillo, entonces, "la concepción gradualista requiere una política de alianzas como la desarrollada durante las campañas de solidaridad con España, y es aquí donde se visualiza el déficit de la organización, porque la misma no se encuentra preparada por tradición, ni por formación para una tarea de este tipo. Por ello, los intentos de actividad política pública serán incipientes, esporádicos y no serán asumidos por la organización". 97

Si bien en estos años que van de 1943 a 1946 se desarticulan los repertorios organizacionales creados por la FACA para la acción sindical; es también el momento en que -como parte de las agencias del movimiento libertario nucleado en la FACA- se gestan propuestas organizativas tales como las Uniones Socialistas Libertarias y el grupo editorial Reconstruir.

A través del análisis de los documentos internos de la organización, se aprecia gran cantidad de correspondencia entre los delegados de todos los puntos

\footnotetext{
${ }^{96}$ Ibídem, pág. 15.

${ }^{97}$ López Trujillo, Fernando (2005). Vidas en rojo y negro..., op. cit., pág. 208. 
del país. En ella, se describen las actividades llevadas adelante y la intención de fortalecer la inserción entre las "masas populares", como ellos las denominan. ${ }^{98}$ Ello demuestra la plasticidad de la organización en el reconocimiento de los escenarios en los que desarrolla su lucha y la capacidad permanentemente de reformular la conveniencia o no de las estrategias empleadas. Sin duda, el recrudecimiento de la persecución estatal y la percepción del cambio que se está produciendo en el nivel social con el advenimiento del peronismo es un desafío que la organización libertaria considera parte de la lucha misma. Los orígenes profundos que expliquen la "crisis" de ese momento será la permanente reflexión de sus intervenciones en periódicos, folletos y comunicados. La denuncia de la implantación de la enseñanza religiosa en las escuelas, la censura a la prensa, la disolución de los partidos políticos, la intervención de las universidades y el ensalzamiento del nacionalismo darán cuenta de que "el gobierno fascista termina de quitarse la careta". 99

Sin duda, la creación de la organización específica para el anarquismo implicó la puesta en escena de nuevas estrategias políticas conformando una pluralidad de acciones orientadas hacia el cambio social y por medio de la participación en los diferentes espacios en que la dominación política y económica del capitalismo y el imperialismo se da de manera más cruenta. Así, las actuaciones en el movimiento obrero, que hasta el momento se habían dado de manera fragmentada, se limitarán a lo dispuesto por la organización única del anarquismo. De esta manera, hemos podido visibilizar la apuesta por organización del movimiento obrero que intenta desprenderse de los "malos hábitos" impuestos por las corrientes comunistas y socialistas y que utilizan los reclamos "justos" de las bases con fines electorales.

\footnotetext{
${ }^{98}$ En el archivo de la Federación Libertaria de la Argentina, existe gran cantidad de documentación aún no clasificada que da cuenta de la actividad de la FACA entre los años 1940 y 1946. También sigue publicándose Acción Libertaria e incluso aparecen nuevas secciones de la organización en diferentes puntos del país. Por ejemplo, en un documento de la sección Provincia de Buenos Aires de la FACA, son enumeradas las localidades en las que tienen representación: Escalada, San Martín, Ciudadela, Junín, Carmen de Areco, Pergamino, Mercedes, Rojas, Haedo, Bahía Blanca, Tandil, San Fernando, San Isidro, Vicente López, Tres Arroyos, Bolívar, Vela, González Chávez, 25 de mayo, Mar del Plata. En Carta de la Federación Anarco Comunista Provincial de Buenos Aires al Secretario del Comité Nacional, noviembre de 1940.
}

${ }^{99}$ Acción Libertaria. Órgano de la FACA. Boletín N 1 . Buenos Aires, enero de 1944. 
Sin embargo, esta mirada crítica de las dirigencias sindicales no estará acompañada de una propuesta positiva en cuanto a la manera en que el movimiento libertario debe construir la democracia y encauzar la lucha de los trabajadores. Las estrategias propuestas no se alejaron de las que habían implementado los foristas a comienzos del Siglo XX tales como la acción directa a través de la huelga general. Pero consideramos que los límites para esas posibilidades de acción y puesta en práctica de diferentes estrategias no tienen que ver sólo con una disposición intrínseca y aislada del movimiento libertario, sino que se articulan con una cantidad de ordenamientos sociales y prácticas políticas y culturales que delimitan su marco de acción y les imprime una lógica dialógica. Sin duda, el escenario político de los años en que se sitúa nuestro trabajo, implica la posibilidad o no de la puesta en marcha de esas estrategias. Y como creemos que no es adecuada la consideración de estas experiencias en clave de "éxito o fracaso" (apostando a una lógica cuantitativa para medir las experiencias de los actores) reconocemos la originalidad y la persistencia de antiguas y de nuevas maneras de intervención y de actuación del movimiento libertario en el escenario político y social de la Argentina de la primera mitad del siglo XX.

\section{Universitarios y movimiento estudiantil}

El 28 de julio de 1943, el nuevo gobierno nacional presidido por Pedro Ramírez, interviene la Universidad Nacional del Litoral, alegando en el decreto $\mathrm{N}^{\mathrm{o}}$ 3953, "que la infiltración de elementos extraños al ambiente estudiantil y al abuso que crea el catedrático su propia función presiona sobre el común del alumnado extraviándose su criterio”. ${ }^{100}$ Allí se instalará Jordán Bruno Genta - escritor,

\footnotetext{
${ }^{100}$ Califfa, Juan Sebastián (2010). "La militancia estudiantil en la Universidad de Buenos Aires entre golpe y golpe, 1943-1955". En Buchbinder, P.; Califa, J. y Millán, M. Apuntes sobre la formación del movimiento estudiantil argentino 1943-1973. Buenos Aires: Final Abierto. Pág. 65. La llamada Reforma Universitaria, se inicia como movimiento estudiantil en la ciudad de Córdoba en el año 1918. Los postulados fundamentales que de allí surgen, giran en torno a dos cuestiones: en primer lugar la reestructuración interna de la universidad (gobierno, autonomía y nuevas pedagogías); en segundo lugar, la apuesta por una función social de la universidad. Berdichevsky, León; Inglese, José; Yegros Doria, Carlos (1965). Universidad y estudiantes. Universidad y
} 
filósofo y docente ultracatólico asesinado en 1974- como interventor. También, casi al mismo tiempo, es intervenida la Universidad Nacional de Cuyo colocando al frente de la misma a un integrante de la Acción Católica. Estos dos hechos definieron la oposición universitaria platense al régimen militar. Alfredo Palacios, hasta entonces presidente de esa casa de estudios, se negó al pedido de las autoridades de dejar cesantes a quienes habían firmado la Declaración sobre democracia efectiva y solidaridad Latinoamericana a través de la cual se expresaron quienes se opusieron a aquellas intervenciones. El 2 de noviembre de 1943 son intervenidas, por decreto, todas las universidades, mientras Gustavo Martínez Zuviría - escritor y político reconocido por su antisemitismo y por adherir al franquismo - asume como nuevo Ministro de Instrucción Pública nacional. Al mismo tiempo, se ilegaliza la Federación Universitaria Argentina y son disueltos los 50 centros de estudiantes y las cinco federaciones estudiantiles existentes, de la mano del encarcelamiento de muchos de sus dirigentes. Cada una de las corrientes ideológicas y políticas existentes en las universidades parten de concepciones diversas sobre la universidad, el rol de los estudiantes universitarios en la sociedad y los fines políticos de su participación. No obstante, con el discurrir de los acontecimientos, el grupo de docentes, graduados y estudiantes - organizados para responder a la violenta intervención "socavadora de derechos" adquiridos en el 18 - construye un repertorio discursivo y de acción colectiva claramente definido por la defensa de los valores de la universidad "reformista". Las motivaciones de la acción colectiva estarán definidas por las cuestiones que los unían. Fundamentalmente, la apuesta por la enseñanza laica, el reclamo por la autonomía del gobierno universitario y la libertad de cátedra así como la identificación del gobierno de facto con el fascismo. En tiempos en los que la actividad políticopartidaria estaba vedada, la participación en la lucha por el reformismo representó para muchos de sus protagonistas la posibilidad de incidir en el destino de la Argentina. Según Graciano,
“(...) los meses de septiembre y octubre de 1945 no sólo resultaron aquellos en los que la crisis política nacional alcanzó su momento de mayor gravedad, sino que su singularidad fue encauzarse en gran

\footnotetext{
peronismo. Buenos Aires, Libera. Sobre los fundamentos y contenidos de la Reforma Universitaria, ver también Ciria, Alberto. y Sanguinetti, Horacio (1968). Los Reformistas. Buenos Aires: Jorge Álvarez. Portantiero, Juan Carlos (1978). Estudiantes y política en América Latina. 1918-1938. El proceso de la Reforma Universitaria. México, Siglo XXI.
} 
medida, a través del conflicto que enfrentaba al gobierno nacional con las universidades. (...) El cuerpo universitario estuvo de ese modo comprometido con todas las iniciativas destinadas a derrocar al gobierno y conseguir una salida política en estos meses y los intelectuales socialistas y anarquistas intervinieron activamente en ellos". ${ }^{101}$

En ese contexto, nos interesa señalar que las ideas libertarias sobre el rol de la universidad tenían sus particularidades. A diferencia de aquellos sectores (como el socialismo y el radicalismo) que pensaron la universidad como núcleo de acción fundamental para intervenir en el escenario político, democrático y electoral, para los libertarios, en un plano doctrinario ésta representa el lugar desde donde se construye la nueva sociedad libre. Se prioriza aquí la idea de "isla" como característica positiva de la institución, como lugar de autonomía desde donde es posible establecer el cooperativismo como forma de organización. Según José María Lunazzi, anarquista, miembro del movimiento libertario y docente universitario, en las universidades

“(...) a los ponderables recursos humanos se agregan la posición de elementos cientificos y de bienes inmuebles, en los cuales se desarrolla hoy una limitada acción experimental e investigación pura y aplicada; esos medios y esos establecimientos se hallan en las mejores condiciones para convertirse en verdaderos talleres cooperativos que comprendan tanto la producción de obras de arte como bienes para la salud y la vivienda". 102

Según esta interpretación, la Universidad es el lugar desde el cual se construye el contra-poder, pero la diferencia con otros espacios privilegiados por los libertarios en esa construcción (por ejemplo, las fábricas, las asambleas, la familia, las asociaciones profesionales, etc.) es la formación científica, las personas altamente capacitadas y formadas en la ciencia son la cuestión fundamental que hacen del sujeto universitario un portavoz invalorable para "la idea" y

\footnotetext{
${ }^{101}$ Graciano, Osvaldo (2008). Entre la torre de marfil y el compromiso político..., op. cit., pág. 303. ${ }^{102}$ Lunazzi, José María (1979). Futurología del taller y de la escuela. La Plata: Ediciones R.A.E. Pág. 46.
} 
propagandistas inmejorables de la nueva sociedad que el anarquismo construye en sus ideales. Estas ideas reflejan la persistencia y el fuerte arraigo del componente cientificista e iluminista en las ideas anarquistas en la Argentina. ${ }^{103}$

En relación a la importancia que el conocimiento científico (universitario) tiene para llevar adelante el proyecto de la nueva sociedad anarquista, el cooperativismo aparece en el discurso anarquista como estrategia positiva y de socavamiento del régimen capitalista. El impulso más significativo en este sentido fue el del ingeniero Aquiles Martínez Civelli, quien además de desempeñarse como docente e investigador de la Universidad Nacional de La Plata, fue responsable y fundador de numerosas cooperativas eléctricas a lo largo y ancho de todo el país. Resulta relevante su concepción sobre el rol de las cooperativas y la posibilidad que ellas representan en pos de la construcción de una nueva sociedad: la cooperativa eléctrica, en este caso, representa "[...] una forma de nacionalización de este servicio público sin estatización; una manera de nacionalizar sin burocratizar, creada espontáneamente por el pueblo)",. ${ }^{104}$

Asimismo, las raíces provinciales de cada una de las universidades (como la de Córdoba, la del Litoral, la de Buenos Aires y La Plata) representan la posibilidad de construir una estructura federativa sobre la que diseñar la nueva sociedad. En efecto, son numerosas las referencias a partir de 1935, a la importancia de construir un sistema federativo como forma particular en pos de crear un sistema alternativo. Fundamentalmente, los trabajos de Juan Lazarte han girado en torno al federalismo.

Además, el movimiento libertario posee otras motivaciones para participar en el campo universitario. Las disposiciones de la organización que los nuclea - la FACA - serán determinantes para comprender su participación allí a partir de 1943. Por ello, resulta interesante establecer la sincronía entre las disposiciones orgánicas, las apreciaciones de la prensa faquista y las actuaciones particulares de los libertarios en los sucesos de la universidad.

\footnotetext{
${ }^{103}$ Barrancos, Dora (1996). La escena iluminada. Ciencia para trabajadores, Buenos Aires, Plus Ultra.

${ }^{104}$ Martínez Civelli, Aquiles (1943). Las Usinas eléctricas populares y cooperativas eléctricas en la República Argentina. Resultados de su funcionamiento. La Plata: Universidad Nacional de La Plata. S/n
}

Bordagaray, M. E. Controversias libertarias: la interpelación anarquista en tiempos del peronismo 
Inmediatamente después del golpe militar de junio de 1943, los anarquistas critican las intervenciones del Partido Socialista y la alianza electoral Acción Argentina. Se evalúa como tibia su denuncia del nuevo gobierno militar y su retardo en pronunciarse en contra de lo que para ellos representó la instalación definitiva del nazi-fascismo en el espacio nacional. ${ }^{105}$ Sin embargo, a pesar de esta crítica al socialismo, debemos reconocer también que, paralelamente a su participación como miembro de la FACA, estos universitarios vienen actuando junto al socialismo en el ámbito académico desde la década de los treinta, tanto en la Universidad Popular Alejandro Korn, como a través de la obtención de cargos docentes y de investigación durante los años de la presidencia de Alfredo Palacios en la Universidad de La Plata (1941-1943).

Los argumentos de la FACA giran en torno a que, frente al avasallamiento por parte del Estado, las posibilidades de lucha y de acciones conjuntas entre todos los que conforman la comunidad universitaria es muy alentadora. La apuesta es fundamentalmente por el movimiento estudiantil:

“(...) La Universidad puede oponer una eficaz barrera a los enemigos de su autonomía y libre desenvolvimiento. Todo depende de la posición que adopte la juventud, de su disposición combativa, de su espíritu de consciente rebeldia". ${ }^{106}$

A partir de 1944, la resistencia se entiende como el intento de frenar el avance de "las fuerzas opresivas" del régimen, sin abandonar el objetivo fundamental de la lucha que es el cambio social:

“(...) Sin dejar de reivindicar con carácter inmediato las libertades públicas inmediatas, relacionamos la actual lucha reivindicatoria, con la más profunda, trascendental y creadora, que libran las masas oprimidas de todo el mundo contra las fuerzas del privilegio económico y de la opresión política en sus diversas formas. Hay que llevar al pueblo de este país la firma convicción de que el derrumbe

\footnotetext{
${ }^{105}$ A. L., No 46, 1943.

${ }^{106}$ Ibídem, pág. 2
} 
de la dictadura actual es solo una cuestión previa y un paso adelante

hacia una verdadera emancipación económica y social". ${ }^{107}$

En febrero de 1945, un decreto da por finalizadas las intervenciones y la presencia católica en los claustro, como parte del proceso "normalizador" encabezado por Farell. ${ }^{108}$ Sin embargo, y no conformes con ello, las universidades y los estudiantes exigían las elecciones presidenciales urgentes. En ese momento se conforma una Junta Superior Universitaria, integrada por los seis rectores nacionales y el presidente de la Federación Universitaria Argentina (FUA). ${ }^{109} \mathrm{La}$ Universidad de La Plata será uno de los centros que enarbolará ese reclamo. ${ }^{110}$ Allí, la intervención normalizadora elegirá como presidente a Alfredo Calcagno (dirigente radical) y al ingeniero Aquiles Martínez Civelli como vicepresidente. ${ }^{111}$

De la mano de esta nueva inclusión de los reformistas, todo el espectro universitario participa de la "Marcha de la Constitución y la Libertad" el 19 de septiembre de 1945, en la que el arco opositor reclama la caída del Ejecutivo bajo el lema: "El Gobierno a la Corte" (Luna, 1973). La Universidad de La Plata participa activamente $\mathrm{y}$, poco tiempo después, el presidente Calcagno es detenido junto con varios consejeros superiores, acusados de participar del intento de golpe militar del 8 de octubre de 1945, contra Farell y su vicepresidente Juan Domingo Perón. La UNLP es clausurada y el edificio central, saqueado. En respuesta a esas acciones, el Rectorado es ocupado por docentes y estudiantes, teniendo los universitarios libertarios un papel fundamental.

\footnotetext{
${ }^{107}$ Boletín FACA (1944) s/d

108 Acerca del gobierno de Farell y el período "normalizador" encabezado por éste, ver Campione, Daniel (2003). Prolegómenos del peronismo. Los cambios en el Estado nacional, 1943-1946. Buenos Aires, FISyP, Manuel Suárez.

${ }^{109}$ Sobre la historia de la FUA, el movimiento estudiantil y su participación en los años de nuestro estudio, remitimos a los trabajos Almaraz, R.; Corchon, M.; Zemborain, R. (2001). ;Aquí fuba! Las luchas estudiantiles en tiempos de Perón (1943-1955). Buenos Aires, Planeta.

${ }^{110}$ Resulta iluminador el aporte de Berdichevsky sobre la experiencia, casi paralela a la de La Plata, en la Universidad del Litoral. El autor remarca la apuesta del grupo de docentes y estudiantes que retorna a la actividad universitaria a partir de febrero de 1945 y su pronunciamiento a favor de la entrega del gobierno a la corte Suprema (petición encabezada por Carlos Sánchez Viamonte, docente de la casa platense y miembro del Partido Socialista). Berdichevsky, León; Inglese, José; Yegros Doria, Carlos (1965). Universidad y estudiantes..., op. cit.

${ }^{111}$ Graciano refiere que esta resulta una buena oportunidad para que aquellos que forman parte del nuevo gobierno universitario se afiancen en su carrera profesional y académica, accediendo a cargos titulares y a los consejos académicos de las facultades correspondientes. Graciano, Osvaldo (2008). Entre la torre de marfil y el compromiso politico..., op. cit.
} 
Resulta muy interesante el hecho de que gran parte de las nuevas autoridades a cargo de las universidades durante la intervención tuvieran también una abierta y explícita afinidad con el movimiento y las ideas libertarias: en la dirección universitaria de 1945, 4 de los integrantes del gobierno tripartito autonombrado por los universitarios platenses, son libertarios. ${ }^{112}$ Más allá de la importancia de lo acontecido durante los 12 días que duró la toma, nos interesa aquí destacar las percepciones y los análisis tanto de Martínez Civelli, vicepresidente a cargo durante el encarcelamiento de Calcagno, como de José María Lunazzi, representante de los graduados. Es allí donde podemos analizar su doble pertenencia: al grupo de los universitarios reformistas y al movimiento libertario.

En los discursos analizados, es posible establecer algunas relaciones muy significativas entre los universitarios libertarios a cargo del gobierno de la universidad, a partir de pensar qué elementos de su pertenencia libertaria están o no presentes. En primer lugar, la apelación a la movilización de los estudiantes y de la juventud universitaria es muy significativa, teniendo en cuenta el lugar que el anarquismo les otorga en la lucha por la libertad frente a las fuerzas totalitarias y la confianza que depositan en su dinamismo y audacia contra las estructuras establecidas. De la mano de este dinamismo de las luchas estudiantiles, es evocada la Reforma del 18, como proceso aún inconcluso del cual este grupo de universitarios (estudiantes, graduados, docentes) forman parte. Lunazzi refiere que aquel movimiento, que continúa en la actualidad, es y fue una "revolución de la inteligencia” (Lunazzi, 1945: s/n).

En los dos discursos analizados, Alfredo D. Calcagno es la figura que sin lugar a dudas los representa. Sin embargo, no es casualidad que solamente se lo interpele como docente, en su calidad de educador, universitario e intelectual y no se evoque la participación política de este importante dirigente radical. Ello porque, como ya lo hemos apuntado anteriormente, la política partidaria no es la que reclaman los universitarios libertarios. Reivindican la participación política pero

\footnotetext{
112 Primer Gobierno Tripartito de emergencia en octubre de 1945. Presidente, Doctor Alfredo Calcagno (en la penitenciaría), Vicepresidente: ing. Aquiles Martínez Civelli. Representante de profesores: Carlos S. Bianchi, Manuel del Carril y Rafael Grinfeld. Representantes de graduados: Adolfo Iglesias y José María Lunazzi. Representantes de los estudiantes: Oscar Martín y Ricardo Reca.
} 
rechazan la política electoral. Según Lunazzi, refiriéndose al público universitario que presencia su discurso, los universitarios:

“(...) tenemos posición en las corrientes sociales del país — con o sin vistas electorales-; los que no, podrán decidirse mañana por lo conocido o por lo a conocer. Pero eso será pasando este jardín a la vereda (...). Somos si, un gremio con derechos y aspiraciones. (Los militares) no tiene que meterse en politica (...) La universidad tampoco; y ella no se mete". 113

En tanto Martínez Civelli refiere que, si bien hasta ese momento todo el grupo de los universitarios ha trabajado en conjunto de acuerdo a un programa "mínimo basado en las coincidencias máximas", como son "[...] la recuperación del mecanismo de la democracia y la libertad; el respeto de los principios de convivencia $[\ldots]$ ".; ${ }^{114}$ representan en realidad principios generales que no concluyen inevitablemente en una construcción política con fines electorales. Es aquí, precisamente, donde el mensaje libertario tiñe el discurso del ingeniero pues refiere que cada corriente e ideología tendrá su propio fin para la lucha que emprenden:

"Cada corriente debe exponer su plan máximo como elemento de la sintesis que resolverá la crisis. Cada agrupación responsable debe decir, no sólo qué principios, qué estructura y qué mecanismo defiende, sino también qué uso se propone hacer de todo ello". ${ }^{126}$

Lunazzi lo proclama de manera más contundente: la apuesta será por una “democracia real". Como proyecto político general debe votarse en la comisión obrera, en la delegación estudiantil, en la representación universitaria. ${ }^{127}$ Como vemos, el escenario político electoral queda fuera de estos "nidos de democracia"

\footnotetext{
${ }^{113}$ Lunazzi, José María (1946). "Discurso pronunciado en acto por el día del estudiante en las puertas de la Universidad de LA Plata, 21 de septiembre de 1945". Revista Americana de Educación, $\mathrm{N}^{\mathrm{o}}$ 2. s/n.

${ }^{114}$ Martínez Civelli, Aquiles (1945). "Discurso pronunciado por el Señor Vicepresidentede la Universidad Ing. Aquiles Martínez Civelli, en el acto de reapertura de la Universidad, el dia 25 de octubre de 1945", en Publicaciones de la Facultad de Ciencias Físicomatemáticas. Serie Tercera, $\mathrm{N}^{\circ}$ 32. Publicaciones especiales de la UNLP, La Plata ${ }^{126}$ Martínez Civelli, Aquiles (1945). "Discurso pronunciado por el Señor Vicepresidente..., op. cit. S/n.
} 
esperables para el movimiento libertario. El escenario político posible frente a la convocatoria a elecciones, representa el momento de fractura del movimiento universitario reformista. Los anarquistas no apoyarán a la Unión Democrática, frente multipartidario formado de cara a las elecciones y como oposición al peronismo. $^{115}$

\section{Consideraciones finales}

En los años que transcurren hasta la llegada del peronismo, y pese a la clandestinidad desde la que actúan, antes que la inacción o el desfasaje de sus propuestas -tal como lo sentenciaran algunos investigadores, percibimos una profunda reflexión y autocrítica en el anarquismo con respecto a la acción realizada hasta entonces. ${ }^{116}$ Incluso, es posible establecer un acercamiento a la posibilidad de una actuación conjunta con todas las fuerzas de izquierda con el fin de impedir el establecimiento definitivo de un régimen totalitario a la manera fascista:

"La FACA contra la dictadura, propone a los sectores de izquierda, a los intelectuales y a todos aquellos que deseen ardientemente el derrumbe total de aspiraciones totalitarias de nuestro país encarnadas demagógicamente por la dictadura clérigo militar, la creación de un basto movimiento en el que participen con todas las

\footnotetext{
${ }^{115}$ Según las actas y los documentos perteneciente a la FACA que hemos consultado, el apoyo y la participación en agrupamientos y "frentes políticos" es necesaria y fundamental a partir del año 1935. Sin embargo, hay reservas en cuanto a participar conjuntamente con los partidos políticos o cualquier impulso que tienda a participar en la vida democrática electoral.

116 "La necesidad de extender la acción proselitista y militante, en un momento de visible decadencia y de replegamiento de todos los sectores de izquierda en general, $y$, en particular, del movimiento libertario, fue el factor que impulsó la iniciativa.". Boletín de la FACA (1951). S/d. Pág. 7.
} 
responsabilidades todos los sectores de izquierda. De un movimiento

orgánico y responsable (...)”."117

En estos años, comienzan a manifestarse las diferencias (políticas, ideológicas y de acción) entre los diferentes colectivos que forman la FACA. El grupo de Rosario propiciará alianzas y participaciones conjuntas (con los partidos Comunista y Socialista y el movimiento sindical); mientras que el Consejo Nacional y la sede Capital Federal de la FACA propiciarán el mantenimiento de una actitud menos abierta a la solidaridad y la participación en los frentes de masas.

El triunfo de Juan Domingo Perón, en febrero de 1946, representó para la organización libertaria la implantación definitiva del fascismo en el país, pero ya no como fenómeno aislado sostenido por un grupo de militares aduladores del clero, sino con un fuerte anclaje y aprobación popular. Sobre este reconocimiento del apoyo popular al peronismo, los anarquistas pensarán la clave para las nuevas estrategias organizativas y los proyectos culturales. Éstos surgen como propuesta para resistir los embates del ahora "democrático" gobierno peronista y sumar nuevos adherentes a la causa libertaria. Así, mientras en el primer período la orientación política de las acciones de la FACA -además de la labor sindical- se centraban en la solidaridad con el pueblo español; en el segundo período, viraron hacia la organización del movimiento obrero; en este momento la militancia libertaria se dará en clave de propuestas culturales y políticas que tendrán como objetivo el llamamiento a amplios sectores de la población que no adhieren al peronismo, pero que tampoco se definen por una propuesta de izquierda. ${ }^{118}$

Los límites para esas posibilidades de acción no tienen que ver sólo con una disposición intrínseca y aislada del movimiento libertario ya que se articulan con

\footnotetext{
${ }^{117}$ FACA, Sección Rosario (1944) s/d.

118 Se percibe, a través de los periódicos, revistas y boletines de la época, gran cantidad de agrupaciones, sociedades de resistencia y sindicatos que adhieren al anarquismo en estos años a lo largo y a lo ancho de la Argentina. En el archivo de la Federación Libertaria de la Argentina, hemos encontrado las siguientes revistas y publicaciones periódicas aparecidas entre 1940 y 1955: revista Avanzada! de Bahía Blanca desde 1944, La Campana, dirigida por Diego A. de Santillán desde 1948; Ateneo, boletín del Ateneo Ciudad de Avellaneda desde 1951; Unión Obrera Local, periódico de la Unión Obrera Local de Mar del Plata desde 1943; Avanzada, revista de las Juventudes Socialistas de Buenos Aires desde 1941, Compañero!, órgano de la agrupación Juvenilia de Rosario desde 1951; Rebeldía, Portavoz del Grupo Independiente, Cuadro $9^{\circ}$, Cárcel de Villa Devoto de 1955.
} 
una cantidad de ordenamientos sociales y prácticas políticas y culturales que delimitan su marco de acción y les imprime una lógica dialógica.

Rechazar cualquier posibilidad de participación política a través del "juego democrático" en cuanto a su inclusión como partido político es, precisamente, la particularidad del movimiento libertario y la que define metodológicamente nuestra elección. Esta manera de interpretar al colectivo ácrata será fundamental para analizar sus agencias en el período peronista. El anarquismo está alejado de cualquier posibilidad de participación en la política partidaria y cualquier tipo de participación que involucre formas de poder representativo y mediado eran absolutamente ajenas a su armazón discursivo. Sin embargo, las estrategias empleadas en sus intervenciones remitirán a los temas que circulan a nivel general de la sociedad en la que los tópicos y las significaciones del discurso peronista son hegemónicos con lo cual aparece una nueva agenda en sus alocuciones a fin de, por un lado, ser contestatario de la propuesta peronista y, al mismo tiempo, ofrecer una interpretación distinta -aún cuando ello implique analizar temáticas que no tienen que ver con su ideario-.

Frente a las interpretaciones que subrayan la fragilidad de las acciones colectivas del anarquismo, precipitada ante la llegada del peronismo al poder, recalcamos aquí la originalidad y la persistencia de nuevas estrategias de intervención y actuación en el escenario político y social del movimiento libertario en

Argentina. 


\section{Capítulo 2}

\section{BIOGRAFÍAS E IDENTIDADES LIBERTARIAS}

La primera dificultad que se nos presenta al abordar las individualidades de quienes sostienen el movimiento anarquista entre los años de nuestro estudio, es el marco "heroico" que rodea las biografías (escritas, publicadas o solo permanente en las memorias de antiguos y nuevos adherentes del anarquismo) de algunos de sus representantes. En general, las acciones públicas son puestas de relieve y obnubilan los aspectos de sus vidas familiares, las desavenencias económicas, la relación con sus compañeros, los trayectos laborales, etc. Estas interpretaciones se han instalado en el imaginario popular y en el sentido común historiográfico. Además, aquellos abordajes que rescatan sus historias de vida, focalizan las experiencias personales que alimentan la figura heroica, como por ejemplo el de la huida con un o una amante, las extravagancias en sus vidas cotidianas, la relaciones con personas de otras clases sociales o de ideas políticas diversas. Del mismo modo, los relatos están marcados por los modelos de género, del militante masculino y de las acciones de las mujeres que se salen de "la regla".

"La militancia en el anarquismo estuvo siempre enmarcada en un nivel de compromiso e idealismo tan fuertes que en más de una ocasión generó admiración y simpatía por parte de individuos y grupos que nada tenían ni tienen que ver con la lucha que esa militancia sostiene. $Y$ es que los Héroes Míticos del anarquismo reproducen el mito del Héroe, tan afecto para nuestra cultura Occidental y Cristiana”. ${ }^{119}$

Las biografías de Simón Radowitzki o Severino Di Giovani, caracterizados por Bayer a partir de su pertenencia a los "anarquistas expropiadores", realzan en general el carácter abnegado, militante y heroico del personaje junto a otros como

\footnotetext{
${ }^{119}$ Hernun (2003) En torno a la anarquía. Sitio web: http://entornoalaanarquia.com.ar/versionhtml/enta13.htm. Visitado por última vez 11/06/2014
} 
Wilckens, Rocigna y las mujeres abnegadas que acompañan a los héroes. ${ }^{120}$ Es el caso de América Scarffó: hija hermana y amante de anarquistas o el de la esposa de Vuotto uno de los presos de Bragado. ${ }^{121}$ Con respecto a las mujeres anarquistas, Salvadora Medina Onrrubia es la referencia inevitable de los estudios que abordan el anarquismo y su brazo anarco-feminista según las interpretaciones discutidas en el capítulo anterior. Los abordajes sobre su vida van desde adjudicarle una adscripción anarco-feminista combativa, prístina y única hasta el de ejemplo de mujer intelectual "burguesa" con simpatías hacia la cuestión social y las ideas

libertarias. $^{122}$

Sin embargo, nos interesa referir también a otro tipo de biografías, las que escapan en cierta medida a estos relatos. Son las autobiografías. Sin la escrita por Juana Rouco Buela, seguramente la referencia de su accionar en pos de lo que ella denominó "la idea", hubiera quedado olvidada. Entre los hombres, Jose Grunfeld o Jacobo Maguid tienen la misma preocupación que Rouco Buela: explicar sus vidas en relación con la historia del anarquismo. En ambos casos, las autobiografías permiten captar los sucesos personales, las experiencias individuales, familiares y laborales como elementos de una cadencia que marcan el itinerario posible de las acciones en sus vidas militantes. Sin embargo, no olvidamos que en el mismo acto de escritura, estos sujetos elaboran una estrategia argumentativa en la cual la dimensión política y polémica se enlazan con el acto confesional e introspectivo en el relato. Reivindican sus propias acciones en torno a la militancia por sus ideales mientras que el ordenamiento cronológico de los hechos no responde exactamente a un orden sucesivo, sino más bien a la autorreferencialidad con respecto a la posición y el lugar ocupado en momentos históricos relevantes. ${ }^{123}$

En general los abordaje biográficos consideran únicamente, según Lahire,

\footnotetext{
${ }^{120}$ Marti, Alejandro (2010). Simón Radowitzky. Del atentado a Falcón a la Guerra Civil Española. De la Campana. Bayer, Osvaldo (2007). Los anarquistas expropiadores y otros ensayos. Buenos Aires, Planeta.

${ }^{121}$ Donatila Barrera fue una militante anarquista que alcanza relevancia anecdótica y romántica ya que, siendo compañera del militante ácrata Danton Ludueña, se enamoró de Pascual Vuotto, uno de los presos durante el proceso de Bragado. Sobre Donatila Barrera, ver Guzzo, Cristina (2014). Libertarias en América del Sur. De la A a la Z. Buenos Aires, Libros de Anarres.

122 Guzzo, Cristina (2014). Libertarias en América del Sur..., op. cit. Saitta, Sylvia (1995) "Anarquismo, teosofía y sexualidad: Salvadora Medina Onrubia”..., op. cit.

123 Sobre las autobiografías, nos remitimos al trabajo de Miraux, Jean Philipe (2005). La autobiografía. La escritura del yo. Buenos Aires, Nueva Visión
} 
“(...) algunos desplazamientos importantes en el espacio social, en términos de volumen $y$ de estructura de distribución de capital poseído (caso de declives sociales o de gran movilidad social ascendente), se acaba por olvidar que también existen desplazamientos y o cambios en el universo familiar (convertirse en padre, divorciarse si estaba casado...) en el universo de amistad, etc., lo mismo que en el orden socioprofesional (...)". ${ }^{124}$

De este modo, partimos de descreer de los relatos que se centran en los campos socioprofesionales o políticos para explicar las trayectorias de vida. Nuestro objetivo, al abordar las biografías, no es el de enumerar las características del colectivo anarquista a partir de la suma de las individualidades de sus sostenedores sino, mas bien, explicar la heterogeneidad de las experiencias de quienes se movilizaron políticamente tras la bandera anarquista.

Sin duda, en tiempos en que el anarquismo pierde la masividad del apoyo entre los sectores populares, las individualidades de quienes organizan y sostienen el movimiento tiene un lugar primordial para explicar su historia entre los años de nuestro estudio. Pero la vida de quienes abrazaron la causa anarquista, de quienes veremos desplegar sus acciones durante los años del primer peronismo, no comienza ni acaba en sus experiencias de acción política y/ o pública. Es allí, en la diversidad de las experiencias, marcadas por su origen social y de género, en donde veremos desplegar sus biografías.

De este modo, seguimos los planteos de Lahire, para quien las condiciones sociales (materiales, estructurales) "antes que dar por supuesta la sistemática influencia del pasado sobre el presente (...) presiona en todo momento sobre todas nuestras situaciones vividas (...), las biografías deben pensarse como el

"desencadenamiento de los esquemas de acción incorporadas (producidos en el curso del conjunto de las experiencias pasadas) por los elementos o por la configuración de la situación presente (...), las

${ }^{124}$ Lahire, Bernard (2004). El Hombre Plural ..., op. cit. Pág. 72 
maneras con que una parte de las experiencias pasadas incorporadas es movilizada, convocada, despertada por la situación presente”. ${ }^{125}$

Estas marcas de origen son la arena en la que creemos se despliegan las estrategias individuales conscientes y no conscientes, racionales y no racionales, por interés, por estrategias, por amor.

Resta una pequeña referencia acerca de aquellas personas referentes del anarquismo que abordaremos en su individualidad: Jacobo Maguid, Jose Grunfeld, Juan Lazarte, José María Lunazzi, Herminia Brumana, Iris Pavón y Ana Piacenza. $\mathrm{Su}$ elección como integrantes del movimiento libertario no ha sido casual. Responde, en primer lugar, a la importancia que el mismo movimiento les ha atribuido como organizadores/as y propagandistas del anarquismo a partir de 1930 y como principales sostenedores del antifascismo en clave libertaria. En segundo lugar, pero no menos importante, estas mismas personas (fundamentalmente los varones) han sido y son permanentemente referidos como vértebras fundamentales de la columna anarquista a lo largo de casi todo el siglo XX tanto en la prensa escrita como entre los mismos militantes del movimiento libertario. Por último, se rescatan trayectorias que evidencian que las luchas políticas fueron de la mano de una vida amorosa y familiar compartida. Abordar a estos/as sujetos/as permitirá visibilizar una parte importante de sus biografías y comprender sus aportes al ideario y el movimiento anarquista en el compromiso conjunto y en el diálogo cotidiano así como también, nos permitirá captar cierta configuración subjetivoidentitaria que la militancia compartida pudo haber agregado a sus posicionamientos.

Es necesaria, también, una breve mención acerca de aquellos/aquellas que no abordaremos en el presente capítulo y que se nos presentan como referentes ineludibles en nuestra historia: Diego Abad de Santillán como así también Salvadora Medina Onrrubia. ${ }^{126}$ En primer lugar, nuestro interés con el presente

\footnotetext{
${ }^{125}$ Ibídem, Pág. 77.

${ }^{126}$ Sobre Abad de Santillán, De la Rosa, María Fernanda (2012). Diego Abad de Santillán. Una utopía en rojo y negro. Editorial Académica Española. En numerosa la producción en torno a la figura de Salvadora Medina Onrubia: Álvaro Abós. "La Venus Roja", en Todo es Historia, No 408, julio de 2001, 6-29. Barrandeguy, Emma (1997). Salvadora. Una mujer de Crítica. Buenos Aires, Vinciguerra. Delgado, Josefina (2007). "Estudio preliminar", en Las descentradas y otras piezas teatrales de Salvadora Medina Onrubia. Buenos Aires, Colihue. Delgado, Josefina (2005).
} 
capítulo reside principalmente en visibilizar a quienes cumplieron un rol preponderante en la organización del movimiento libertario pero cuyas acciones no han sido recuperadas ni por la historiografía y acaso tampoco por las memorias militantes. Por otro lado, si bien cronológicamente sus acciones dentro del anarquismo se extienden por lo menos hasta los años 40 , no nos ha sido posible identificarlos con las organizaciones que pretendemos abordar, aunque sí como referentes para las mismas.

Metodológicamente, intentaremos realizar un abordaje colectivobiográfico, siguiendo los lineamientos de las biografía según a Lahire y la sociología de la crítica. ${ }^{140} \mathrm{Si}$ bien muchos de los datos biográficos (fecha y lugar de nacimiento, matrimonio, hijos, principales acontecimientos) con los que abordaremos este capítulo ya han sido expuestos en muchos trabajos, nos interesa recuperarlos para reconstruir las biografías militantes de manera colectiva en cuanto a que la referencia a seguir en cada uno de los caminos, son sus acciones en relación a los ideales que los movilizan. ${ }^{141}$ Para ello, hemos seleccionado algunos ítems a partir de los cuales ordenaremos algunos datos y construiremos otros sobre las y los sujetos actuantes.

\section{Inmigración y sociabilidades}

Las narraciones historiográficas sobre la historia del anarquismo en la Argentina, refieren en general a estos orígenes europeos descriptos por Oved.

"Dentro de esa ola migratoria, que atrajo campesinos, obreros y miembros de la baja clase media, se encontraban comprensiblemente

Salvadora. La dueña del diario Crítica. Buenos Aires, Sudamericana. Guzzo, Cristina (2003). Las anarquistas rioplatenses. 1890-1990. Phoenix, Orbis Press. Saítta, Sylvia (2006) "Prólogo", en Las descentradas. Buenos Aires, Tantalia. Tarcus, Horacio (2004). "Anarquismo y teosofía. Simón Radowitzky y Salvadora Medina Onrubia” en Políticas de la Memoria No 5, verano.

140 Retomamos la cuestión "colectiva" de las biografías en cuanto a algunos itinerarios que creemos comunes pero mayoritariamente diversos. Es por ello que nuestra apuesta se diferencia de la mirada que sobre las biografías colectivas han primado en la historia social o en la historia intelectual, en las cuales ha primado la mirada de Bourdieu 
141 Por ejemplo, los diccionarios biográficos: Tarcus, Horacio (2007). Diccionario biográfico de la izquierda argentina: de los anarquistas a la" nueva izquierda" 1870-1976. Buenos Aires, Emece Editores. Guzzo, María Cristina (2014). Libertarias ..., op. cit.

muchos activistas de las federaciones obreras españolas. Estos activistas, que llegaron a la Argentina como emigrantes por motivos económicos o como exiliados políticos, trajeron consigo la ideología y sus posiciones en las controversias ideológicas, así como las tradiciones que habian consolidado en su patria. Hubo muchos que cambiaron su estilo de vida, su status (aldeanos se convirtieron en urbanos) y también sus enfoques, después de su traslado a un país nuevo y a nuevas condiciones. (...) Pero muchos otros buscaron el camino para renovar su actividad anarquista en la Argentina". ${ }^{27}$

Del mismo modo, la historiografía, ha manifestado que el movimiento anarquista en los últimos años del Siglo XIX y principios del XX floreció y se sostuvo fundamentalmente entre inmigrantes, europeos, que se instalan en los crecientes pueblos y ciudades rioplatenses. La mayoría de estos inmigrantes eran hombres jóvenes, solteros y contaban sólo con la referencia de algún paisano o familiar lejano para elegir su destino en las pampas argentinas. ${ }^{128}$ Las ideas políticas acompañan, en paralelo a este proceso de movilidad, de traslado y de llegada de inmigrantes en búsqueda de posibilidades de ascenso social por medio de una mejor posición económica. Otros, venían expulsados por su actividad política en sus países de origen. ${ }^{129} \mathrm{Si}$ bien estadísticamente se habla de una preeminencia de la inmigración italiana hasta 1914, en relación al mundo de las ideas y puntualmente a los grupos anarquistas, “(...) el anarquismo argentino se desarrolló a la zaga del de España y estaba sujeto a la influencia de los militantes y las ideas originadas en la península". ${ }^{130}$ Estas apreciaciones son las que han estructurado la historia de las ideas y de la historia social en la Argentina. Es decir, partiendo de identificar las zonas de origen o de gestación de determinadas configuraciones

\footnotetext{
127 Oved, Iaacov (1991) "Influencia del anarquismo español sobre la formación del anarquismo argentino", en Revista estudios Interdisciplinarios de América Latina y el Caribe, Vol 2.1. S/n

128 Devoto, Fernando (2003). Historia de la inmigración en la Argentina. Buenos Aires, Sudamericana. Bjerg, María (2009). Historias de la inmigración en la Argentina. Buenos Aires, Edhasa, entre otros.

${ }^{129}$ Cesano, José Daniel (2010). Inmigración, anarquismo y sistema penal. Los discursos expertos y la prensa Córdoba y Buenos Aires 1890 - 1910 (Protesta social, flujos migratorios y criminalización). Buenos Aires, Editorial Alción.

${ }^{130}$ Oved, Iaacov (1991). "Influencia del anarquismo...”, op. cit. 
ideológicas y políticas, sería posible rastrear los derroteros de quienes adhirieron y promulgaron esas mismas ideas en otros territorios y otros tiempos. Sin embargo, y sin desconocer estas miradas e interpretaciones de la historia del anarquismo y la inmigración en nuestro país, los inicios de nuestra historia se ubican en un lugar levemente desplazado de este eje. Comprendemos las configuraciones identitarias como mecanismos complejos, en constante proceso de reformulación y siempre provisorios, histórica y geográficamente situados al mismo tiempo. ${ }^{131}$

Esta introducción al problema resulta de fundamental importancia puesto que la totalidad de las biografías que hemos seleccionado se inscribe dentro de esa historia general de la inmigración: son hijos de inmigrantes, nacidos en Argentina o llegados de niños desde Europa del Este, España e Italia. Pero su procedencia europea no se relaciona directamente con la comunión en las ideas anarquistas. Más bien, los orígenes familiares de estos militantes hablan de experiencias de sociabilidad en una amplia cultura política, republicana, de izquierdas, cercanas al socialismo, pero que se manifiesta en un hogar en el que se apuesta a la lectura y la formación política autodidacta como una práctica cotidiana.

Durante la guerra ruso japonesa (1904-1905), los padres de Jacobo Maguid huyen de la persecución que sufren los judíos en la Rusia de los zares. Se instalan en la ciudad de Santa Fe:

"Mi padre obrero y mi incansable madre para sus ocho hijos, aman la lectura y la comentan. No se conforman con el diario porteño $<$ Idische Tzaitung $>$, sino que reciben el semanario Idische Gazete desde los Estados Unidos. En un cajón tienen libros variados". ${ }^{132}$

Segundo en una familia de 8 hijos, Jacobo Maguid narra de esta manera, en su autobiografía, parte de sus registros de la infancia. ${ }^{133}$ Denota la relación estrecha entre su familia y sus orígenes judíos europeos a través de la lectura de los

\footnotetext{
${ }^{131}$ Latour, Bruno (2008). Reensamblar lo social..., op. cit.

132 Jacinto Cimazo (1995). Recuerdos de un libertario..., Pág. 21.

${ }^{133}$ Horacio Tarcus ha recopilado la totalidad de los seudónimos empleados por Maguid en su vida estudiantil y como militante organizador del anarquismo en sus constantes intervenciones por medio de la escritura en la prensa orgánica: Macizo, Jacinto Cimazo, Floreal O. Pina, Víctor Guidmá, Jorge Niero, Edgar Balpervi, M. Acizo. Tarcus, Horacio. Diccionario biográfico de la izquierda argentina... op. cit. 
periódicos en idioma idish locales e internacionales. ${ }^{134}$ En otro pasaje de su autobiografía relata una sociabilidad que, fundada en las prácticas religiosas del judaísmo, relaciona a esta familia humilde con otras provenientes del "centro de la ciudad", sectores comerciantes con una posición más acomodada:

"En la víspera de Iom Kipur, nos emociona el rezo de Jaezan y la conmovedora melodía del Kol Nidrej con alaba al altísimo. Pero antes, los chicos vemos que el patio se llena de gente frente a mesas preparadas para recibir contribuciones en dinero para instituciones benéficas de la colectividad. (...) En ese único Día del Perdón aparecen caras conocidas o nuevas de los que constituyen la clase privilegiada: tenderos, muebleros, negociantes (...)". ${ }^{135}$

Del mismo modo, José Grunfeld relata en sus memorias el prestigio que contaba su padre entre los sectores más prominentes de Moisés Ville, una de las colonias judías más antiguas e importantes de las creadas en territorio argentino. Ese prestigio no se relaciona con su posición económica, ya que son una familia numerosa que vive del trabajo en tareas rurales y de la explotación de una parcela en la colonia del Barón de Hirsch. Su prestigio se apoyaba en sus valores

"morales" y en haber sido reconocido como un hombre culto y comprometido con los valores de la comunidad. ${ }^{136}$ La familia Grunfeld, originaria de Berasavia, de orígenes humildes como la de Maguid, se instala en la colonia judía santafesina también en los primeros años del Siglo XX. ${ }^{137}$ Los hermanos José, Rafael y David transitarán juntos no solamente su infancia en el pueblo, sino el viaje a la ciudad y

\footnotetext{
${ }^{134}$ Sobre la inmigración judía en la Argentina ver Avni, Haim (1986) La inmigración judía en la Argentina. Sobre anarquistas judíos en la Argentina: Naum Krichmar (1964). La Colonia Narcisse Level (1909-1964). Bernasconi, La Pampa, Cooperativa El Progreso. López, Antonio y Rawin, Gregorio (2001). "The Jewish Rationalist Association of Argentina" en L'Anarchico e L'Ebreo: storia di un incontro. Milano, Eleuthera. Amedeo Bertolo e Annalisa Bertolo editors. 179-186. Mc Gee Deutsh, Sandra (2010). Crossing borders, claiming a Nation: A history of Argentine Jewish women. Durham, NC, Duke University Press.

${ }^{135}$ Jacinto Cimazo (1995). Recuerdos de un libertario..., pág. 13.

${ }^{136}$ Grunfeld, José (2000). Memorias de un anarquista. Buenos Aires, Nuevo Hacer.

${ }^{137}$ Carlos José Rocca asegura que los Grunfeld provienen de Kishinev, capital de Moldavia. Nosotros nos apoyamos en la información brindada por Grunfeld en su autobiografía Memorias de un Anarquista.
} 
la participación en el movimiento anarquista. ${ }^{138}$ Reciben educación primaria en la colonia (la religión era una parte fundamental en la formación de los niños allí).

Resulta interesante introducir aquí una cuestión que, si bien por lo pronto sólo será enunciada, puede ayudar a comprender la particularidad de algunas trayectorias biográficas que tienen sus orígenes en las familias judías y por lo cual su adscripción étnica resultará relevante en tiempos de acción política en el anarquismo. Pensando en las comunidades de principios del siglo XX, Falcón asegura que

“(...) los anarquistas adoptarán el principio de la organización de grupos sobre la base de criterios de origen étnico o comunidad lingüística. No obstante, las características de descentralización que tenía la actividad anarquista, hacía mucho más evidente la persistencia de estos criterios, a través de la proliferación de periódicos publicados en diferentes idiomas. Además, a diferencia de los socialistas, casi nada los incitaba a oponerse a la sobrevivencia de la identidad étnica. Su antipoliticismo descartaba cualquier preocupación por la naturalización de los extranjeros". ${ }^{139}$

Como veremos, la diferencia entre las adscripciones étnicas de judíos y españoles o italianos, es que la judía (sea laica o religiosa) se consuma también en una identidad política, elegida y reformulada en el nuevo territorio. Si bien son conocidas para la historiografía las prácticas de asociación por parte de italianos, españoles, franceses, éstas perderán con el paso del tiempo y su institucionalización, los preceptos ideológicos en los que se fundaron. ${ }^{140}$ Ejemplos

\footnotetext{
${ }^{138}$ En su biografía, Rocca destaca que José Grunfeld trabajó en distintas ocupaciones en su adolescencia en Ceres, Rosario y La Plata. Diferente a sus hermanos David y Rafael que realizan estudios universitarios y logran reconocimiento internacional en sus especialidades: Rafael como físico y David como médico cardiólogo. Rocca, Carlos José (1998). José María Lunazzi. Semblanza de un Socialista Libertario. Editorial Universitaria de LA Plata

${ }^{139}$ Falcón, Ricardo (2011). "Izquierdas, régimen político, cuestión étnica y cuestión social en Argentina (1890-1912)", en Estudios Sociales, 40 (1), 193-221. Pág. 204

${ }^{140}$ Sobre asociacionismo e inmigración: Devoto, Fernando (1992). Asociacionismo, trabajo e identidad étnica: Los italianos en América Latina en una perspectiva comparada. Cemla-Cser-Iehs. Otero, Hernán (2000). "Endogamia e integración de inmigrantes en la Argentina moderna. Balances y perspectivas desde un enfoque regional." Seminario sobre Población y Sociedad en América Latina, comp. Boleda and Mercado (Salta, Argentina, 2000). Otero, Hernán (2010). "El asociacionismo francés en la Argentina. Una perspectiva secular.", en EIAL: Estudios
} 
de ello son las asociaciones mutuales, las sociedades de socorros mutuos, las cooperativas de crédito, etc. Estas identidades nacionales/étnicas reflotan en tiempos de los conflicto mundiales como la Primera y la Segunda Guerra así como también con la Guerra Civil española (1936-1939). Ejemplo de estas organizaciones es la participación de José Grunfeld y muchos otros militantes anarquistas judíos en la Asociación Racionalista Judía desde su fundación en 1916 y a lo largo de todo el siglo XX. ${ }^{156}$

La identificación de estas familia con "lo judío" (llámese nacionalidad, país de origen o religiosidad) se entrelaza con un interés que se extiende a la mayor parte de las familias de los futuros militantes anarquistas: la educación como un bien intangible y prioritario, al mismo tiempo que las familias educan en la cultura y las lecturas que hablan de lo universal y son las más interesadas en lograr la integración a las comunidades en las que se insertan. La familia Lazarte, afincada en la ciudad de Rosario, de orígenes españoles y pertenecientes a una clase media incipiente (madre modista, padre comerciante y distribuidor) también apuestan por la educación como valor incuestionable en la formación de sus hijos. ${ }^{157}$ El paso de su hijo Juan por la Escuela Racionalista de Rosario, ejemplo de las apuestas anarquistas de "alternativa" a la educación estatal y dirigida por el mismo Julio Barcos, denota un interés por parte de sus padres no en cuanto al ideario anarquista, pero si al menos racionalista y de las pedagogías que apuntan a la

nombre de la Patria: asociacionismo y nacionalismo en la Argentina en torno de la Primera Guerra Mundial.”, en AAVV. 200 años de Iberoamérica (1810-2010), 303-315.

156 Sobre la Asociación Racionalista Judía, ver Dujovne, Alicia (2008). "Cartografía de las publicaciones periódicas judías de izquierda en Argentina, 1900-1953", en Revista del Museo de Antropología, 1, 121-138. También Bilsky, E., Trajtenberg, G. y Weinstein, A. E. (1987). El movimiento obrero judio en la Argentina (Vol. 4). AMIA/Editorial Milá. Sandra Mc Gee Deutch nos habla de las mujeres que han dado sustento a la organización y su relación con el anarquismo y el Partido Comunista de la Argentina. Mc Gee Deutsch, S. (2010). Crossing Borders, Claiming a Nationooo, op. cit.

157 Sobre la biografía y trayectoria de Juan Lazarte, remitimos a los trabajos: Ledesma Prietto, Nadia (2012) "Revisando la categoría de intelectual para el anarquismo posterior a 1930. Un estudio de caso a través de Juan Lazarte, 1918- 1963”, en Pasado por-venir; Lugar: Trelew, provincia de Chubut; Vol 6.

Interdisciplinarios de America Latina y el Caribe, 21(2), 123-152. Tato, María Inés (2010). “En el

Bordagaray, M. E. Controversias libertarias: la interpelación anarquista en tiempos del peronismo 
Abad de Santillán, Diego, Invaldi, Ángel y Capelletti, Ángel: Juan Lazarte, militante social, médico, humanista. Rosario, Grupo Editor de Estudios Sociales, 1964.

educación como medio para el cambio social. ${ }^{141}$ Culminó sus estudios secundarios en el Colegio Nacional de Rosario.

Para comprender las especificidades en las biografías de las mujeres que desplegaremos en el presente capítulo, es necesario referir a su origen social. Sin duda, la adscripción de estas familias a los sectores medios o en vías de ascenso social son una característica que comparten. Iris Pavón (1906-1951), hija de un maestro andaluz y cuya madre pertenecía a la clase terrateniente andaluza, crece en un ambiente letrado, y donde las prácticas políticas ligadas al socialismo de su padre y su hermano resultan en un temprano interés por parte de Iris por la justicia social y el sufrimiento de los oprimidos. ${ }^{142}$ Comienza a escribir poesía en los periódicos locales de Cruz del Eje apenas alcanzada la adolescencia y su ingreso al mundo laboral también es muy temprano.

En este sentido, la de Herminia Brumana fue una infancia a la que podríamos denominar de "clase media". Nacida en Pigüé, en 1897, su familia apuesta fuertemente por su educación y la de su hermano Florencio, logrando culminar sus estudios secundarios en tiempos en que esto agregaba un valor simbólico a un pasar económico ya consolidado. ${ }^{143}$

\footnotetext{
${ }^{141}$ Fundacionales en la reconstrucción historiográfica del tema de la educación anarquista y racionalista, son los trabajos de Dora Barrancos, en especial Anarquismo, educación y costumbre. Apoyada en la ciencia y el positivismo, los pilares de esta apuesta educativa son la relación entre el conocimiento (teórico) científico y el trabajo manual, al mismo tiempo que reconoce las desigualdades sociales y está orientada a los sectores populares. Existen también abordajes recientes, en los cuales se describen las experiencias de las escuelas racionalistas en Buenos Aires, Rosario y Bahía Blanca. Acri, Martín A. y Cázeres María del C. (2011). La educación libertaria en la Argentina y en México. 1861-1945. Libros de Anarres, Buenos Aires. Carli, Sandra (2002). Niñez, pedagogía y política: transformaciones de los discursos acerca de la infancia en la historia de la educación argentina entre 1880 y 1955. Miño y Dávila. Sardu, A. (2008). "Una molesta piedra en el camino: Educación Anarquista", en Theomai: estudios sobre sociedad, naturaleza y desarrollo, (17), 11. Di Stefano, M. (2005). "Políticas de lectura y escritura en las escuelas del anarquismo en la Argentina a principios del siglo XX. Cuadernos del Sur. Letras," (35-36), 75-95.

${ }^{142}$ Nacida en Lobería, su padre ferroviario es trasladado a Cruz del Eje y es allí donde transcurre la mayor parte de su vida, hasta su temprana muerte en 1951 a los 45 años de edad.

${ }^{143}$ Su padre inmigrante emprendió con buenos resultados, distintas actividades económicas, incluso llegó a poseer campos y propiedades. Sobre Herminia Brumana, remitimos a los trabajos: Queirolo, Graciela (2010) "Herminia Catalina Brumana: la maternidad social a través del magisterio y la escritura", en Valobra, Adriana (editora) Mujeres en espacios bonaerenses. Edulp. También Fletcher, Lea (1987). Una mujer llamada Herminia ..., op. cit. y Samatán, Marta (1974). Herminia Brumana, la rebelde. Buenos Aires, Plus Ultra.
} 
También italianos, los Piacenza resultan chacareros en el pueblo de Moldes, Santa Fe. Con una participación política comprometida por la causa agraria, Esteban Piacenza es referido por la bibliografía como uno de los fundadores de la Federación Agraria de la Argentina. ${ }^{144}$ En sus comienzos socialista, radical con la llegada de Irigoyen, llega a apoyar el fascismo de Mussolini en tiempos en que su hija Ana milita activamente por la causa ácrata. Un hogar cargado de debates y compromiso social en el que, según Grunfeld -quien posteriormente sería su pareja, Ana resultó ser "la oveja negra" por sus ideas y acciones que se contraponían a las de la familia de clase media rosarina de la que esta familia formaba parte a partir de su traslado a la ciudad.

De orígenes también italianos, la familia Lunazzi se instala en La Plata y logra que su hijo José María realice los estudios primarios en la Escuela Experimental Anexa y el Colegio Nacional de La Plata, establecimientos de excelencia y vanguardia en cuanto a los contenidos y los métodos de enseñanza. Además, Lunazzi crece y se forma intelectualmente en los talleres de imprenta que su familia materna poseía en la ciudad, y que eran lugar de reunión de la intelectualidad y la bohemia de la época. Los Talleres Gráficos Olivieri Domínguez resultan de gran apoyo en los años posteriores a los proyectos editoriales y de propaganda en que Lunazzi se embarca de la mano del movimiento anarquista y en los años de los debates universitarios por la Reforma Universitaria.

Hasta aquí, los escenarios en los que se emplazan las biografías discurren entre las pequeñas ciudades pampeanas. Con la excepción de quienes se afincan o llegan a Rosario, las familias reseñadas se instalan en áreas rurales o semirurales. Sus vidas transcurren aquí alejadas de los sucesos de las grandes ciudades como Buenos Aires, en donde la historiografía concuerda es el momento de hegemonía del anarquismo como ideología que moviliza sindicalmente a la mayoría de los obreros. ${ }^{145} \mathrm{La}$ experiencia política previa de las familias migrantes así como el compromiso y la participación en los lugares en que se afincan representan marcas indelebles para los jóvenes que serán recién llegados en las ciudades portuarias,

\footnotetext{
${ }^{144}$ Pagani, R. y Perego, E. (1989). La cuestión agraria en 1919: chacareros y terratenientes (Vol. 8). Centro Editor de América Latina. Archetti, Eduardo (1977). El proceso de capitalización de campesinos argentinos. Cahiers du monde hispanique et luso-brésilien, 28(1), 123-140.

${ }^{145}$ Sobre el anarquismo hasta 1910 en la Argentina, ver la introducción de este trabajo.
} 
pujantes y conflictivas de la Argentina de los años 20. Si hay algo que caracteriza a la totalidad de las experiencias narradas, es la rápida y constante movilidad social.

No solamente de ascenso social por medio de un mejor pasar económico, sino por el traslado de una región, ciudad o pueblo. Como veremos en los apartados siguientes, los escenarios en los que estos sujetos se emparentan con las ideas anarquistas, son más bien urbanos, pero no solo Buenos Aires. Ciudades como Rosario, Córdoba, Bahía Blanca o La Plata resultan puntos fijos en los que los actores se desplazarán en todos los años de nuestra historia. Esto no implica desconocer experiencias libertarias como la de Pampa Libre en La Pampa, o las adscripciones anarquistas de los obreros portuarios marplatenses. Lo mismo con respecto al anarquismo entre los trabajadores rurales patagónicos o los de las empresas forestales en el litoral o las uniones obreras diseminadas a lo largo y ancho de todo el país. ${ }^{163}$

Junto a la apuesta por la escolaridad, ocurre en paralelo una socialización política temprana de la mano de las familias. Otra característica que se comparte es que son familias tradicionales, con roles de género bien diferenciados. Ninguna de las biografías reseñadas tiene cuna en lo que podría denominarse "una familia anarquista" (que en general refiere a un modelo construido desde la literatura anarquista), en donde la mujer también practica "la idea" en la crianza de los hijos, en la camaradería amorosa y con los compañeros anarquistas (hospitalidad, atención al perseguido). ${ }^{164}$

${ }^{163}$ Sobre el movimiento anarquista en La Pampa y la provincia de Buenos Aires, ver Etchenique, Jorge (2000). Pampa Libre. Anarquistas en la pampa argentina. Amerindia/Universidad Nacional de Quilmes. Angel Borda da cuenta del movimiento sindical anarquista en Entre Ríos, en su autobiografía: Borda, Ángel (1987). Perfil de un libertario. Cuentos, narraciones y poesías del litoral. Historia Sindical de Entre Ríos. Buenos Aires, Editorial Reconstruir.

${ }^{164}$ Barrancos, Dora (1990). Anarquismo, educación..., op. cit. También Bracamonte, Lucía (2006). 
“Anarquismo y cuestión femenina. Una visión sobre lo público y lo privado en la prensa de Bahía Blanca a principios del siglo XX”, en e-l@tina, Revista electrónica de estudios latinoamericanos, Unidad de Docencia e Investigaciones Sociohistóricas de América Latina (UDISHAL), Vol. 4, N ${ }^{\circ}$ 16, Facultad de Ciencias Sociales, Universidad de Buenos Aires, Argentina, Buenos Aires, julioseptiembre

\section{Educación, juventud y socialización política}

Herminia Brumana se recibe de maestra normal en 1916. Al mismo tiempo que ejerce la docencia primaria en la localidad de Pigüé, emprende su trabajo literario e intelectual. Funda la revista literaria Piĝ̂e y comienza a relacionarse con escritores y políticos porteños quienes colaboran asiduamente con la publicación. ${ }^{146}$ Entre ellos, Juan Antonio Solari, por entonces estudiante universitario comprometido con el socialismo y el movimiento estudiantil. Herminia también participó en las publicaciones de la agrupación anarcocomunista Insurrexit, la cual pugnaba por una reforma universitaria que incluyera al mundo obrero y de los trabajadores en los claustros. ${ }^{147}$ Solari era parte del mismo grupo y, en el año 1921, se casa con Brumana y tienen su único hijo un año después.

Lunazzi, Lazarte y los Grunfeld/Grinfeld participan activamente en sus años universitarios del mismo movimiento de crítica y reforma. La Plata en los años 20 resulta la ciudad en que confluyen muchas de estas biografías. ${ }^{148}$ Lazarte participa activamente desde Córdoba, en los años en que se instala en esa ciudad para culminar sus estudios de Medicina. ${ }^{149}$ Jacobo Maguid se traslada a La Plata a

\footnotetext{
${ }^{146}$ En estos años, Brumana participa al mismo tiempo de innumerables proyectos editoriales, diversos y algunos contrastantes. Poesía, ensayo, notas, opiniones en publicaciones políticas como La Vanguardia, La Protesta, Nuestra Tribuna, Vida Femenina,; conviven con otra en Caras y Caretas, Mundo Argentino, El Hogar, Estampa, La Novela Elegante, La Novela Semanal, y el suplemente literario de La Nación, entre muchos otros. En 1918 había publicado su primer libro de lectura: Palabritas

${ }^{147}$ Sobre Insurrexit de los años 1920-1921, ver Tarcus, Horacio (2004). "Revistas, intelectuales y formaciones culturales izquierdistas en la Argentina de los 20", en Revista iberoamericana, 70(208), 749-772. Los alcances de la Reforma Universitaria de 1918 y los debates serán tratados en el capítulo 5 del presente trabajo.

${ }^{148}$ Sobre la vida universitaria en la ciudad de La Plata, resulta iluminador el aporte de Gustavo Vallejo. Vallejo, Gustavo (2007). Escenarios de la cultura científica argentina. Ciudad y Universidad (1882-1955). Madrid, Consejo Superior de Investigaciones Científicas.

149 Una vez terminados sus estudios secundarios, Juan Lazarte se traslada a Buenos Aires a inscribirse en la carrera de Medicina, la cual abandonó, para ingresar en el Instituto del Profesorado de Buenos Aires donde se recibió de profesor en Ciencias Biológicas. Se traslada a La Plata en donde cursa estudios de antropología, paleontología, anatomía y embriología junto con Florentino Ameghino. En paralelo, sus conocimientos sobre la flora y fauna del país lo convirtien en un naturalista reconocido. Viaja a Estados Unidos en 1916, donde profundiza sus estudios en genética. Cuando ese país ingresa a la Primera Guerra Mundial, volvió y se instaló en Córdoba para culminar sus estudios de Medicina. Ledesma Prietto, Nadia (2012). "Revisando la categoría de intelectual...", op. cit.
} 
estudiar Ingeniería en el año 1925. Con una beca para costear los estudios, rápidamente socializa con el movimiento estudiantil: "En la primer asamblea de alumnos, me eligen delegado para integrar la Comisión del Centro de Estudiantes. A poco andar, vuelco en las reuniones mi pasión por una causa que conmovió al mundo: la defensa de Sacco y Vanzetti (...)". ${ }^{150}$ Maguid funda el PUI (Partido Universitario de Izquierda) en La Plata y edita Palabras Rebeldes. Al mismo tiempo, forma parte del Grupo Ideas y trabaja por un período como editor de La Protesta. Allí comparte militancia con un joven Lunazzi, que realiza estudios en educación en la Facultad de Humanidades y realiza prácticas docentes en zonas rurales. El Grupo Ideas será la cristalización de estas militancias dispersas, ahora por primera vez organizadas en torno a una de las tendencias en que se ha dividido el movimiento anarquista de los años 20: la antorchista. Si bien su publicación aparece hasta mediados de la década siguiente, los años 27 a 30 resultan ser las de mayor actividad y organización. Temas como la liberación sexual de las mujeres, el comunismo libertario como idea organizadora para el anarquismo, el movimiento estudiantil como eje para el futuro de las luchas anarquistas, evidencian los intereses renovados y muchas veces opuestos a los ligados a los sectores protestistas y foristas. ${ }^{151}$

El encuentro de las vidas reseñadas con las ideas anarquistas se da en momentos en que el enfrentamiento entre las dos tendencias libertarias más importantes se manifiesta violentamente. A partir de la Revolución Rusa y del quiebre del grupo editor de La Protesta en 1915, el periódico La Antorcha se convirtió en el referente del sector en que participa la mayoría de ellos. La separación de estos dos sectores ayudó a conformar dos identidades -protestistas y antorchistas- que hacia 1924 se enfrentaron abierta y violentamente. ${ }^{152}$

\footnotetext{
${ }^{150}$ Jacinto Cimazo (1995) Recuerdos de un libertario..., op. cit.

${ }^{151}$ No existen trabajos que aborden puntualmente al grupo Ideas. Es nombrada por Dora Barrancos, y aquellos estudios que abordan las luchas internas del anarquismo en los años 20. Ta,bién es referido por los estudios biográficos como los de Carlos Rocca y en las autobiografías de Juan Rouco, Cimazo y Grunfeld.

152 Anapios, Luciana (2008). "El anarquismo argentino en los años 20. Tres momentos en el conflicto entre La protesta y La Antorcha”, en Papeles de trabajo. Revista electrónica del Instituto de Altos Estudios Sociales de la Universidad Nacional de General San Martín. ISSN: 1851-2577. Año 2, nº 3, Buenos Aires, junio.
} 
Marcos Dukelsky, quien deviene en compañero de vida Iris Pavón, proveniente como Grunfeld y Maguid de una familia de inmigrantes rusos, será el director y administrador de uno de los proyectos editoriales "antorchistas", el periódico "Pampa Libre” de General Pico (La Pampa), entre abril y agosto de 1927. En estos años, José Grunfeld, se acerca al anarquismo de la mano de sus hermanos Rafael y David Grinfeld que en tiempos de la campaña por la libertad de Sacco y Vanzzetti en 1925, se encontraban desarrollando sus carreras universitarias. ${ }^{153}$ En los años subsiguientes, se relaciona con grupos libertarios de Rosario, Tres Arroyos y La Plata. Es arrestado en 1926, luego de ser descubierto mientras reparte folletos en un acto político en Rosario. Los tres hermanos actuaron de manera conjunta en el movimiento libertario de las décadas siguientes y tuvieron un papel protagónico en la conformación de numerosas organizaciones y proyectos culturales libertarios. Familia, lazos familiares y de amistad son determinantes para entender el acercamiento al campo político anarquista y la posibilidad de extender en el tiempo su rol como propagandistas y referentes del anarquismo. Bernard Lahire reivindica precisamente estas variables para comprender "los grandes" desplazamientos en las biografías de las personas. La mayoría de las veces, pensar en sujetos que se desenvuelven en el campo político, lleva a minimizar cuestiones como desplazamientos o cambios en el universo familiar (por ejemplo convertirse en padre o madre, casarse, divorciarse si estaba casado) y en el universo de amistad, lo mismo que en el orden laboral y profesional. ${ }^{154}$ Piacenza se encontraba en estos años realizando sus estudios de abogacía en la Universidad del Litoral, situación no muy frecuente ya que la educación universitaria todavía estaba vedada para buena parte de las mujeres. ${ }^{155}$ Sin duda, las agitaciones políticas y las causas que movilizaban al anarquismo no le eran ajenas. Sin embargo, es en estos años cuando conoce a José Grunfeld, ya comprometido militante anarquista y de paso por las ciudades y pueblos santafesinos. Referimos con esto a la heterogeneidad de

${ }^{153}$ Rocca. Carlos José (1993). El Dr. Rafael Grinfeld o el precio de la investigación en la Argentina. Buenos aires, Editorial Geocart, 1993. Graciano, Osvaldo (2008) Entre la torre de marfil y el compromiso político. Intelectuales de izquierda en la Argentina 1918-1955. Quilmes, Universidad Nacional de Quilmes.

${ }^{154}$ Lahire, Bernard (2004) El Hombre Plural...; op. cit.

${ }^{155}$ No solamente las condiciones económicas de su familia le permitían seguir son sus estudios universitarios. Sin duda un interés por su propia independencia, ligada quizá a ideales cercanos al feminismo, la alejan del destino "naturalizado" para las mujeres de la época: el matrimonio y la maternidad. Sobre las mujeres, la universidad y los modelos de género ver Nari, Marcela (2004). Políticas de maternidad y maternalismo político, op. cit. Sobre las mujeres en la universidad:

Palermo, A. I. (2006). "El acceso de las mujeres a la educación universitaria. Revista argentina de sociología”, 4 (7), 11-46. 
experiencias y de situaciones que pueden acercar a los militantes con las ideas que los movilizan. A diferencia de la experiencia de Ana, Iris Pavón será madre en estos años y vuelve ya como madre sola y a cargo de su hijo a su ciudad Cruz del Eje, luego de un breve paso por la ciudad de Córdoba donde había trabajado en una concesionaria de autos. ${ }^{156}$ Experiencias diversas, genéricamente diferenciadas, nos indican que las mujeres de esta historia transitan también trayectorias diversas para llegar a comulgar con las ideas anarquistas.

Analizando la literatura anarquista, Juan Suriano percibe que a los varones, "la idea" se les presentaba como una revelación:

"La conversión al anarquismo se operaba no a través de la toma de conciencia clasista, sino mediante la revelación de la idea libertaria en un clima fuertemente emocional que representaba a un nuevo mundo moral basado en la ciencia y el progreso. (...) Los activistas portadores de estas ideas más que como organizadores actuaban como educadores, propagandistas o agitadores responsables de revelar al pueblo las bondades de la buena nueva basadas en los beneficios de la ciencia, del progreso y de la instrucción. A la vez eran considerados como verdaderos elegidos de la verdad y de la justicia”. 157

Sin embargo, para los casos que seguimos y venimos describiendo, "la idea" es una de las opciones políticas en momento de conflictos sociales y de amplia participación juvenil en las calles de las ciudades, como por ejemplo, los mítines por Sacco y Vanzzetti y la solidaridad por los presos de Bragado. Según las trayectorias analizadas, la adscripción anarquista tiene que ver más con la admiración que le despiertan las acciones callejeras motivadas por la acción represiva de los estados (al encarcelar y perseguir a los militantes sociales). La época de los “oradores brillantes" y de los "sujetos iluminados" por la idea dejan de

\footnotetext{
156 “A los veinticuatro años, con su compañero Oscar Ramón Rojas, apodado "El Pibe", un jugador de fútbol de Cruz del Eje, tuvo a su único hijo, José Rojas, y se asumió como madre soltera desafiando a la tradicionalista sociedad cordobesa. De su hijo, quien se radicó en Córdoba, tuvo dos nietos: Oscar Ernesto y Graciela. Además, Iris adoptó a una sobrina segunda llamada Lucía Fernández.”. Guzzo, María Cristina (2014). Libertarias..., op. cit., Pág. 110.

${ }^{157}$ Suriano, Juan (2004). Anarquistas..., op. cit., pág. 94 
ser el modelo del militante anarquista para ser reemplazado por el de las acciones concretas sea en las calles, en las cárceles, en la organización y en la propaganda.

Resta una reflexión final para este apartado. Primero, las biografías que seguimos ¿responden o escapan a lo esperable de acuerdo a bibliografía que nos precede y da contenido a las interpretaciones? En segundo lugar, nos preguntamos cuáles son los elementos de lo social que definen sus acciones y cuánto de ellas podría explicarse por lo derroteros individuales, familiares, de amistades o de trayectoria laborales. Sin duda sus roles como organizadores, las múltiples identidades y lazos que cada uno estableció con sus profesiones, en sus redes familiares y sus trabajos, explican una dispersión fundante y sobre la cual es necesario recalar para comprender el apartado siguiente.

\section{Luchas políticas, experiencias de vida e identidades}

Comenzamos este apartado proponiendo dos referencias de los propios actores sobre este período.

"Durante el viaje no tengo muchos tiempos para charlas o distracciones. He traído libros que compré con 200 pesos que me dio Kaplan (editor de Nervio y después de Imán). No son textos ideológicos, sino tratados de ingeniería que repaso. Pienso en la obra de reconstrucción social que impulsan los libertarios, quizá me asignen un trabajo como técnico". ${ }^{158}$

Aquí, Maguid introduce sus múltiples identificaciones. Por un lado, su título de ingeniero civil obtenido en medio de detenciones, viajes, cambios de domicilio y ocupación lo habilitará, según su criterio a realizar tareas técnicas para el frente republicano español. Sin embargo, una vez llegado a la península, los altos mandos de de las organizaciones anarquistas le reservan cargos de importancia en las editoriales y órganos de propaganda.

\footnotetext{
${ }^{158}$ Jacinto Cimazo (1994). Recuerdo..., op. cit., Pág. 41 
La segunda referencia corresponde a las memorias de José Grunfeld, quien relata en pocas palabras la historia, que es su historia.

“Al llegar al puerto de Buenos Aires, tras algunas paradas en Río de Janeiro, nos esperaban familiares y Anita con nuestra hijita, que por

entonces tenía poco más de 6 meses...Así, sin mayores solemnidades, terminaba una etapa de actuación que comenzó el 19 de julio de 1936. Llegué a la Argentina a fines de julio. Pocos días después se declaraba el conflicto entre Inglaterra y Francia contra Alemania e Italia, es decir, la Segunda Guerra Mundial". ${ }^{159}$

Aquí se entrelazan sucesos fundamentales en el devenir del mundo contemporáneo así como también eventos que marcarán su propia vida: la derrota republicana en España, el comienzo de la Segunda Guerra Mundial y el nacimiento de su primera hija. Ambas citas dan cuenta de la interrelación que hemos identificado en las biografías entre procesos generales, estructurales, políticos y sociales y los derroteros personales, diarios, familiares y de la "vida privada". Ambos son fundamentales para comprender en profundidad las trayectorias biográficas.

El golpe militar de 1930 encuentra a Lunazzi liderando la Federación Universitaria. Logra huir a Montevideo y es recibido por Luce Fabbri, reconocida militante anarquista italiana también exiliada política junto a su padre, Luigi Fabbri. Realizará tareas docentes en todos los lugares en que se instala, aunque sea por breve tiempo. Desde 1927, en compañía de su esposa Clotilde Beaufays, realiza todo tipo de tareas asistenciales en alejados parajes de La Pampa en los que Lunazzi lleva la tarea educativa. Ella lo acompañará en sus trayectos y se encargará del cuidado de sus tres hijos: Luis, Margarita y Helena. ${ }^{160}$ De estos años datan, también, sus comienzos en la docencia universitaria de la mano del pedagogo Alfredo Calcagno.

\footnotetext{
${ }^{159}$ Grunfeld, José (2000). Memorias..., op. cit., pág. 235

${ }^{160}$ Posteriormente conocerá a quien será la madre de su cuarto hijo José Joaquín, la bióloga e investigadora Otilia Martínez Ungría.
} 
Si bien Herminia Brumana venía participando desde su escritura en distintos proyectos editoriales anarquistas, la década del 30 la encuentra profundamente comprometida con las ideas y las organizaciones libertarias. Del mismo modo, Ana Piacenza e Iris Pavón se comprometen como propagandista de las causas anarquistas en los mismos años. La fuerte represión policial a los militantes políticos (más aún a los anarquistas) reunirá a los hermanos GrinfeldGrunfeld, Dukelsky, Maguid y Lunazzi en la cárcel de Villa Devoto a partir de 1931. También, se encontrará allí la mayoría de los militantes libertarios (de todas las facciones y tendencias). Pero el encarcelamiento y posterior enjuiciamiento de Vuotto, Mainini y De Diago, representará el episodio a partir del cual se convoque a amplios sectores políticos (radicales, socialistas, comunistas, demócrata progresistas) y la puerta de entrada para muchas mujeres a la política. Ana Piacenza e Iris Pavón responden a esta convocatoria y, en la dinámica del proceso, irán madurando su simpatía hacia el anarquismo hasta convertirse en voces acreditadas y reconocidas por el mismo movimiento libertario.

Paradójicamente o no, es en este nuevo espacio de participación en el que tanto Iris como Ana establecerán lazos personales y afectivos con Dukelsky y Grunfeld. En el momento en que Iris conoce a Dukelsky (alrededor del año 1934), ella ya tenía su hijo resultado de una relación anterior. José Grunfeld describe en su libro el rechazo que la familia de Ana tenía por las ideas libertarias de su hija y por la relación que se establece entre ambos. Maguid describe puntillosamente de qué manera conoce a la familia Quesada y entabla relaciones con quien será su compañera de toda la vida: Juanita Quesada. Familia libertaria, oriunda de Bahía Blanca pero afincada en Buenos Aires, son referencia para gran parte del movimiento anarquista a lo largo del siglo XX. ${ }^{161}$

Lo cierto es que, junto al de otras mujeres, los nombres de Iris Pavón y Ana Piacenza aparecen como representantes de los Comités Pro-presos de Cruz del Eje y Rosario, respectivamente. Dukelsky representa al de Córdoba y Grunfeld acompaña a Piacenza en el de Rosario. Si bien no contamos con los discursos y conferencias realizados durante la campaña que los llevó por todo el país durante varios años,

\footnotetext{
${ }^{161}$ Fernando, Juanita, Nía y Menchu Quesada fundan y militan en la Federación Anarco Comunista de la argentina. Recientemente Cristina Guzzo ha abordado la familia Quesada para describir las trayectorias individuales y colectivas tanto de sus miembros como de quienes de una $\mathrm{u}$ otra manera se relacionaron con ellos. Guzzo, Cristina (2014). Libertarias ..., op. cit.
} 
son constantes las referencias a sus actividades e intervenciones en la prensa orgánica anarquista, fundamentalmente a partir de 1935 en el periódico Acción Libertaria así como también en la prensa local y nacional. Por otro lado, es destacable el apoyo y la consideración que las mujeres de los comités de ayuda a los presos de Bragado tienen con respecto a las esposas de los mismos. Para Iris Pavón estas "mujeres de presos" son el ejemplo para otras mujeres, en cuanto sostenedoras (en lo económico y lo afectivo) de la familia, de los hijos y de sus maridos presos. Representan, en palabras de Pavón, la resistencia al avasallamiento y la incansable lucha de las mujeres de hombres militantes de "la idea". Muchas de las acciones del comité estarán dirigidas a obtener donaciones para las familias.

Mercedes Yusta Rodrigo nos brinda una serie de herramientas conceptuales para visibilizar a las mujeres y sus luchas (en su caso de estudio, contra el franquismo). Al hacer hincapié en las "pequeñas resistencias" de la vida cotidiana, llega al concepto de "mujer de preso", y con ello habilita a pensar las acciones de estas mujeres como parte de las estrategias femeninas en la lucha y la resistencia política/civil. Según la autora, las mujeres de presos,
“(...) aseguraban la subsistencia cotidiana de (los presos) y a la vez tejían entre ellas redes de solidaridad que acababan convirtiéndose en redes con significación política". ${ }^{162}$

Creemos relevantes estas consideraciones, fundamentalmente, porque abren el margen para el estudio de la historia de las mujeres. Por otro lado, resultan iluminadoras las apreciaciones de Mabel Bellucci sobre las características de las organizaciones de mujeres en estos tiempos:

\begin{abstract}
"La concurrencia cotidiana de mujeres a estos grupos informales no era demasiado numerosa ni regular (...) Los fuertes desgastes personales provocan una tendencia a la dispersión frente a las exigencias de las luchas desarrolladas dentro y fuera del hogar, la ausencia de la colaboración de sus familiares intimos, la sobre imposición de las obligaciones domesticas con las extra-domesticas, e
\end{abstract}

\footnotetext{
${ }^{162}$ Yusta Rodrigo, Mercedes (2005). "Las mujeres en la resistencia antifranquista, un estado de la cuestión”, en Arenal, No 12. enero-junio 
incluso los obstáculos permanentes presentados por otras mujeres que no alcanzan a entender la dimensión e importancia de las propuestas y operaciones existentes", 163

Si bien no podemos hablar sobre Iris, Herminia o Ana como ejemplos de la falta de continuidad en la militancia de las organizaciones de mujeres, sí es el caso de las demás mujeres que las acompañaban. Resulta muy dificultoso visibilizar los nombres de quienes las acompañaron y sostuvieron estos intentos organizativos de grupos de mujeres en los años 30. Sin embargo, hay otra regularidad descripta por Bellucci en la que podemos ubicar a estas mujeres: la de haber sido esposas o compañeras de otros militantes anarquistas:

"El caso específico de las mujeres cuyos compañeros son militantes o adherentes al ideario anarquista, se refuerza el rol idealizado de la maternidad por su presencia activa dentro del núcleo familiar. Las razones son evidentes: la familia anarquista casi siempre esta al margen de la ley. Un libertario vive observado, perseguido y condenad@porel orden establecido: es corrid@delos conventillosy de los lugares laborales, pasa largos periodos en prisión, en la clandestinidad o deportad@. Esto provoca que las obligaciones mayores y menores en torno al mantenimiento material y emocional de los vástagos y de la unidad doméstica decaigan en la mujer. Ahora bien: si ella, en vez de cumplir el rol de compañera es o acompañante es también activista a la par de conyugue o camarada, la situación se complejiza por las expectativas tan altas puestas en su "noble" función de ser pieza fundamental en la unidad de la familia". ${ }^{164}$

Esta triple carga, la de madre, trabajadora y militante, es la que acompaña la biografía de Herminia, Iris y Ana y explica los vaivenes en sus itinerarios de acción política.

\footnotetext{
${ }^{163}$ Bellucci, Mabel (s/d) "Anarquismo y feminismo: el movimiento de mujeres anarquistas con sus logros y desafíos hacia principios de siglo http://www.nodo50.org/mujerescreativas/mabel_bellucci.htm

${ }^{164}$ Ibídem, 
La creación de la Federación Anarco Comunista Argentina (FACA), en el año 1935, tiene a Grunfeld, Maguid, Lunazzi y Lazarte cumpliendo un rol fundacional. En este contexto, se discute por primera vez, entre otros temas, la incumbencia de crear o sostener o no grupos específicamente de mujeres y que pugnen por reivindicar aquellas cuestiones que se relacionan con el género.

Hasta este momento, Grunfeld, Lunazzi, Maguid y Lazarte son exponentes de los discursos disruptivos que se enfrentan a los instituidos por la FORA y La Protesta en el período anterior al golpe militar de 1930 y que conforman el campo político anarquista de ese momento. Sin embargo, a partir de ese momento, y por medio de un trabajo intenso cuyo fin es crear una organización para el anarquismo, ambos se erigen como sostenedores de un nuevo discurso libertario que tiene como base el comunismo anárquico y la lucha organizada como punto de partida para el cambio social.

Es también después de 1930 que estas mujeres (Brumana, Piacenza y Pavón) se insertan en el campo político libertario aceptando, en líneas generales, las reglas impuestas por los sostenedores de estos nuevos discursos e ideas. Durante la campaña por los presos de Bragado, en la correspondencia privada que mantiene Iris Pavón con la compañera de Pascual Vuotto, se aprecia una crítica a la poca permeabilidad a la sensibilidad de la mayoría de los hombres, entre los que Vuotto representa una excepción.

\section{"La educación y el ambiente los han cerrado (a los hombres) a todo sentimiento que no sea el de dominación con respecto a la compañera. La quieren arregladita, hermoseada, aunque sea a base de artificios y de cosméticos (...)". ${ }^{165}$}

Este es un documento privado, y debe comprenderse en ese marco. Sin embargo, como veremos más adelante, las apuestas de Iris girarán en torno a ensalzar el rol de la madre como clave para el cambio social reforzando la idea de "igualdad" entre hombres y mujeres para lograrlo.

\footnotetext{
${ }^{165}$ Pavón, Iris Teresa (1952). Pasión de Justicia, Buenos Aires, Editorial Reconstruir. 
Herminia Brumana participa activamente en la propaganda por la actividad de los comités pro presos de Bragado, instando a las mujeres a la colaboración y el compromiso por las causas que deben movilizarlas por su "naturaleza femenina":

"Insisto en lo dicho: quien no está contra la justicia, está con ella. Las mujeres de mi país que no se declaran, de viva voz o por escrito, solidarias al movimiento iniciado protestando por la condena de los presos de Bragado, se pone incondicionalmente de parte de la injusticia. ¿Con qué derecho hablarán luego de ética, de moral, de principios, quienes no han sido capaces de indignarse ante la mayor indignidad concebible? Quienes condenan a inocentes, guiados por intereses de clases, cometen un acto que rebaja la condición humana". 166

Sobre las apuestas conceptuales de Brumana, profundizaremos en el capítulo 3 de este trabajo. Solo mencionaremos aquí que, en general, su ideario contiene nociones como la responsabilidad ética individual, la maternidad como elección racional de las mujeres, el amor como un contrato racional entre dos personas que se aman y se respetan, entre otras cuestiones que abordaremos más adelante. ${ }^{167}$

El proceso de inserción progresiva de estas mujeres en el campo libertario recién comienza en este período y se establecerá definitivamente en los años que abordaremos a continuación, los de la lucha antifascista. Hablamos del ingreso al campo político de estas mujeres en particular, lo que no quiere decir que desconozcamos que "las mujeres" participan en el escenario público y político de la Argentina y el mundo con anterioridad, incluso dentro del anarquismo. ${ }^{168}$ Así como las trayectorias señaladas en el apartado anterior explicaban el establecimiento de nuevas legitimidades en los discursos y prácticas del campo político del anarquismo por parte de los hombres, también muchas mujeres entran plenamente al campo político de la mano del interés por subvertir discursos y significados.

\footnotetext{
${ }^{166}$ Quesada, Fernando (1974). El Proceso de Bragado. Buenos Aires, Editorial Korrigan

167 Ver Bordagaray, María Eugenia (2011) "La anarquistas argentinas y el voto femenino (19461955), en Barry, Carolina (comp.). Sufragio femenino. Prácticas y debates políticos, religiosos y culturales en Argentina y América Latina. Buenos Aires, EDUNTRF.

168 Sobre los movimientos de mujeres, la participación política de las mujeres y el movimiento feminista, remitimos al trabajo de Barrancos, Dora (2007). Mujeres en la Sociedad Argentina. Una historia de cinco siglos, Sudamericana, Buenos Aires. La misma autora ha dado cuenta de las
} 
Tanto Iris Pavón y Marcos Dukelsky como Ana Piacenza junto a José Grunfeld, Hermina Brumana, Jacobo Maguid, Juan Lazarte y Lunazzi experimentan en esta etapa trayectos diferenciados. Ante los requerimientos de la Confederación Nacional de los Trabajadores (CNT) española y la Federación Anarquista Ibérica (FAI), la FACA tiene una participación comprometida en el proceso español entre 1936 y 1939, con varios militantes libertarios en el frente y ocupando cargos de importancia en la península. Nombra como delegados en España a Jacobo Prince, Jacobo Maguid y José Grunfeld, quienes ocuparon cargos de máxima responsabilidad en el diario "Solidaridad Obrera", "Tierra y Libertad" y en las respectivas organizaciones CNT y FAI. Por otro lado, como ya lo hemos anunciado en el capítulo 1, la FACA intervino en la formación de numerosos comités populares de Ayuda a España al mismo tiempo que fundó (siguiendo los criterios de la CNT y de la FAI), el Servicio de Propaganda de España e impulsó la formación de la Solidaridad Internacional Antifascista (SIA).

Iris Pavón, junto a otras mujeres, impulsa la creación de la Asociación Femenina Antiguerrera de Cruz del Eje. Éste es un grupo femenino que, si bien no responde solamente a las que comulgan con las ideas anarquistas, es impulsado por la prensa orgánica faquista “Acción Libertaria”. En su primer manifiesto, apela a un discurso que ensalza a la maternidad como estado natural de las mujeres: “(...) madres antes que mujeres; (...) como madres las llamamos y como madres las esperamos; ${ }^{188}$ así también como la importancia de estas para sostener al hombre que es quien desata las verdaderas batallas contra la opresión:

agencias femeninas dentro del anarquismo en numerosos trabajos. Barrancos, Dora (1990 a). Anarquismo, educación y costumbres..., op. cit. De la misma autora, (1990 b). "Anarquismo y sexualidad"... op. cit.. Y también de Barrancos, (1996). "Mujeres de Nuestra Tribuna: el difícil oficio de la diferencia", op. cit.

${ }^{188}$ Pavón, Iris (1952). Pasión...op. cit. Pág 55

"Somos las compañeras, las madres, las hijas de los eternos parias que en tiempos de paz llenan los talleres y las fábricas y en tiempos 
de guerra los mataderos que pomposamente se llaman <gloriosos campos de batalla $>$ ". 169

Se destacan las similitudes con la experiencia de las organizaciones femeninas antifascistas de España, fundamentalmente en relación al ensalzamiento de la participación política de las mujeres en clave maternal, en la politización de la maternidad como elemento distintivo de las mujeres y sus luchas contra el totalitarismo. $^{170}$

Según la prensa libertaria, las acciones de esta agrupación de mujeres no se limitan a recaudar fondos o a funciones de asistencia al pueblo español, sino que participa activamente (puntualmente en el caso de Cruz del Eje) en la organización de mitines y reuniones políticas junto a otras organizaciones. También actuó en el Comité de Ayuda al Pueblo español junto a Marcos Dukelsky y, de acuerdo a los registros de la SIA, fue durante un tiempo la responsable de ese organismo en la Argentina.

Siguiendo a Ana Piacenza en su actuación en España, entre 1936 y 1938, creemos importante recalar en su paso por la agrupación y publicación "Mujeres Libres”, donde desarrollará una línea editorial e ideológica en pos del reconocimiento de las mujeres en su especificidad. ${ }^{171}$ Mientras actúa allí, también será editora responsable de la publicación "Tierra y Libertad" y delegada de la FACA en el Grupo C de la FAI en Barcelona.

Si bien Grunfeld nunca se expresó críticamente a lo actuado por su compañera, las constantes omisiones a ello también deben ser tenidas en cuenta.

\footnotetext{
${ }^{169}$ Ibídem,

${ }^{170}$ Yusta Rodrigo, Mercedes (2011). "La construcción de una cultura política femenina desde el antifascismo (1934-1950)", en Aguado, Ana y Ortega, teresa (dir.). Feminismos y antifeminismos. Culturas políticas e identidades de género en la España del Siglo XX. Valencia, PUV.

${ }^{171}$ Sobre la experiencia de la agrupación y posterior publicación "Mujeres Libres", remitimos a los siguientes trabajos Nash, Mary (1999). Rojas: las mujeres republicanas en la Guerra Civil. Madrid, Taurus. Andrés Granel, Elena (2006). "Mujeres Libres: emancipación femenina y revolución social", en Germinal. Revista de Estudios libertarios, № 2.
} 
En una serie de cartas personales disponibles para su consulta en el archivo de la Federación Libertaria de la Argentina, Grunfeld escribe a sus compañeros de la FACA en la Argentina sobre sus percepciones de la situación española, y dedica a Piacenza sólo comentarios sobre lo actuado en Tierra y Libertad. Por otro lado, ella refiere permanentemente a la importancia de la lucha política que está llevando a cabo y que la tiene como protagonista. ${ }^{172}$

Mientras tanto Juan Lazarte, instalado desde 1923 en el pueblo de San Genaro (Santa Fe), ejerce la medicina y ayuda en la formación de cooperativas de servicios para la localidad, práctica extendida entre los anarquistas con conocimientos científicos universitarios. ${ }^{173}$ Participa como representante local de la organización internacional anarquista SIA, recaudando fondos y realizando actividades en todo el país. El gremialismo médico es otra de sus ocupaciones en este momento:

"Como gremialista médico, impulsó a sus colegas a unirse ante la que él consideraba la amenaza del avance del Estado sobre su autonomía profesional y a basar sus principios profesionales dentro de lo que el consideraba la Medicina Social". ${ }^{174}$

Comprometido desde su cotidianeidad con los ideales libertarios, es en esta década cuando nacen sus hijos y cuando publica sus principales obras. ${ }^{175} \mathrm{La}$ liberación sexual de la mujer y la maternidad consciente y voluntaria son los ejes en los que Lazarte vincula sus conocimientos médicos con sus ideas anarquistas, temas carísimos a la militancia y a la historia del anarquismo desde sus comienzos. ${ }^{176}$

\footnotetext{
${ }^{172}$ Cartas personales de Ana Piacenza y José Grunfeld en AAVV (2005). Catálogo de publicaciones anarquistas, $\mathrm{s} / \mathrm{d}$.

${ }^{173}$ Aquiles Martínez Civcelli, ingeniero mecánico y militante anarquista de la Universidad de La Plata, dedicará sus escritos y su trabajo a organizar cooperativas eléctricas en varios pueblos de la provincia de Buenos Aires. Sobre el mismo, ver Bordagaray, M. E. (2012). Anarquismo y movimiento universitario en Argentina, 1935-1950. CS Journal/Revista CS, (9).

174 Ledesma Prietto, Nadia (2012) "Revisando la categoría de intelectual para el anarquismo posterior a 1930. Un estudio de caso a través de Juan Lazarte, 1918-1963”, en Revista Pasado Por Venir, Año 6, N ${ }^{\circ}$ 6, Trelew.

${ }^{175}$ Lazarte, Juan (1932). Revolución sexual de Nuestro Tiempo. Buenos Aires, Nervio. Lazarte, Juan (1935). Sociedad y prostitución. Rosario, Librería Ruiz. Lazarte, Juan (1936). Contralor de los nacimientos. Rosario, Librería Ruiz.

${ }^{176}$ Barrancos, Dora (1990 a). Anarquismo..., op. cit. 
A la vuelta de España, por decisión de la FACA, Maguid se instala en la casa de Lazarte para realizar un libro sobre los sucesos de España. De esa experiencia, Maguid relata algunos elementos de su vida cotidiana:

"Trabajamos en la muy nutrida biblioteca, ayudados por el fichero que su muy buena compañera ayuda a mantener al día. La casa es amplia y en el terreno del fondo, varios "bichos" conviven en armonía. Lazarte atiende en el consultorio a sus pacientes; tiene un modesto coche en que va adonde lo llamen, a visitar enfermos en las chacras cercanas, a recorrer cientos de kilómetros para intervenir como orador de fondo en actos a los que fue invitado, que a veces son dos o tres en un mismo día. (...) En la semana que convivo con él y su mujer, sus dos hijos están ausentes, estudiando". ${ }^{177}$

Difícilmente llegue hasta nosotros un relato similar sobre las mujeres libertarias, es decir, relatos de un observador que en tono de contemplación elogiosa observa la vida cotidiana de mujeres, como por ejemplo Brumana o Pavón. Es conocido por la historiografía de las mujeres que las acciones de aquellas que trascienden y logran ser visibilizadas por la historia se limitan a sus voces públicas, en la actividad política, en el ámbito masculino por excelencia. Es decir, pocas veces hallaremos descripciones de la vida cotidiana de las mujeres anarquistas (y de las mujeres militantes en general), en tiempos en los que la lucha política tiñe sus agencias y parece consumir los demás aspectos de sus biografías. Lo que tenemos en esos períodos en los que se retiran momentáneamente de la arena pública, es silencio. Ese silencio esconde los cambios en la estructura familiar, separaciones, nacimientos, traslados, viajes forzados, maternidades.

José Grunfeld habla de un período de crisis familiar cuando, al momento de su regreso y el de Ana desde España, no tienen trabajo ni vivienda propia donde establecerse junto a su hija recién nacida.

"Me veía frente a un panorama incierto y preocupante. Carecía de ocupación y debía asumir la responsabilidad de mantener a mi familia. Momentáneamente fui a parar a la casa de los padres de

${ }^{177}$ Jacinto Cimazo (1995). Recuerdos..., op. cit. Pág. 58 
Anita: Doña Elisa Moing y don Esteban Piacenza. Fui recibido con respeto y cuidadosa consideración (...),${ }^{178}$

En tiempos de penurias económicas, Grunfeld reconoce que a pesar de sus ideologías opuestas, fue posible establecer vínculos familiares amorosos, respetuosos y en donde primó la solidaridad sobre las diferencias políticas.

"Don Esteban, que habia sido socialista y fundador de la F. A. A. junto con Netri, se inclinó al fascismo, erigido por un ex socialista Benito Mussolini. No obstante esta inclinación justificada por la necesidad de un ejecutivo fuerte, pasé más de un año conviviendo en su casa sin sentirme incómodo, porque en general se evitaban los comentarios políticos (...)", 179

En esta estadía junto a los Piacenza, Grunfeld descubre la problemática de los colonos santafesinos y de los arrendatarios agrícolas en general. Es a partir de esta experiencia que sus inquietudes serán expuestas ante la FACA y ésta hará suyos los reclamos y los intentos de organización en el campo. ${ }^{200}$ Por sus lazos familiares, logra también conseguir un empleo.

Maguid describe sus peripecias en la búsqueda de un trabajo estable una vez llegado de España. Si bien se instala en Santa Fe, en donde lleva adelante acciones militantes como representante de la FACA, las posibilidades laborales concretas se le presentan en Buenos Aires. Es por eso que se instala finalmente en esa ciudad.

"Un excelente amigo, con quien compartí una de las pensiones estudiantiles platenses tiene una empresa y me incorpora a su oficina. Entre cálculos y controles de obra transcurren los años ". ${ }^{180}$

\footnotetext{
${ }^{178}$ Grunfeld, José (2000). Memorias..., op. cit., pág. 242

${ }^{179}$ Ibídem, Pág. $243{ }^{200}$ Este tema ha sido abordado en Bordagaray, M. E. (2011). "Anarquismo en la Argentina: repertorios organizacionales y de acción colectiva en el movimiento libertario, 19351955." Repertorio Americano, №21, 45-60. También Ascolani, Adrián (2009). El sindicalismo rural en la Argentina: de la resistencia clasista a la comunidad organizada, 1928-1952. Universidad Nacional de Quilmes.

${ }^{180}$ Jacinto Cimazo (1995), Recuerdos..., op. cit. Pág 61.
} 
De esta manera, Maguid "acomoda" su militancia y recupera lazos extendidos con anterioridad según sus necesidades laborales y de subsistencia. Una vez afincado en Capital, con su nuevo trabajo, retoma el trabajo militante. Es en este momento que conoce a su futura esposa Juanita Quesada, hermana de su amigo Fernando y con quien tiene a su única hija Alicia. Para 1943, Maguid trabaja en la Corporación de Transportes como ingeniero, puesto que sostendrá hasta su jubilación.

\section{Las biografías en los repertorios organizacionales del anarquismo}

El golpe militar de 1943, renueva la experiencia persecutoria para quienes habían experimentado la caída de la república española. También para aquellos que, sin pasar por España, sufrieron la represión y la cárcel en los primeros años de la década del 30.

Grunfeld y Piacenza fueron presos en Rosario entre agosto de 1943 y octubre de 1944:

"Una comisión policial invadió nuestra casa, tuvimos que acompañarlos. Nuestra hija Miri, de tres años y medio, quedó con los abuelos que tenían su residencia cerca. (...) Anita (lo supe después) fue alojada en una cárcel de mujeres administrada por monjas, donde pasó muchos meses, hasta que, por trámites del padre, le permitieron estar recluida en la casa paterna, lo que le permitió estar permanentemente con nuestra pequeña (...)". ${ }^{181}$ Nuevamente sus lazos familiares alivian la situación a la que son conducidos por su militancia libertaria: la cárcel. Iris Pavón no correrá la misma suerte, y su hijo quedará al cuidado de su familia en Cruz del Eje. Dukelsky y Pavón fueron detenidos durante 4 meses en Córdoba, ella en la Cárcel de Mujeres del Buen Pastor. Así como estas dos parejas fueron

${ }^{181}$ Grunfeld, José (2000). Memorias..., op.cit. Pág. 252 
encarceladas, cientos de militantes libertarios fueron perseguidos también.

Sin embargo, en este contexto de fuerte represión y persecución, a través del análisis de los documentos internos de la organización se aprecia gran cantidad de correspondencia entre los delegados de todos los puntos del país. Pero las vidas de los militantes anarquistas siguieron rigiéndose por las necesidades de subsistencia y los itinerarios familiares. Grunfeld consigue trabajo en la Biblioteca de la Facultad de Ciencias Físico-matemáticas de la Universidad del Litoral en Rosario. Lunazzi desarrolla tareas docentes y de investigación en la Facultad de Humanidades de La Plata. Lazarte continúa con sus tareas médicas y edita junto a otros la revista Nervio y Hombre de América. En paralelo, continúan las tareas organizativas en la FACA. Esta situación se resquebraja nuevamente a partir de 1946, cuando Lunazzi y Grunfeld son expulsados de sus puestos de trabajo en la universidad. Maguid retiene su puesto laboral, a expensas de ocultar su participación en el movimiento anarquista. Pero los intentos organizativos no decaen y florecen nuevas experiencias: entre marzo y junio de 1946, se crean la Unión Socialista Libertaria de Rosario, la Unión Socialista Libertaria de La Plata y la Unión Socialista Libertaria de Capital Federal. A pesar de que se presentan como agrupaciones independientes y sin ninguna relación orgánica con la FACA, los miembros fundadores de las Uniones Socialista Libertarias son históricos militantes faquistas: Ana Piacenza, Juan Lazarte José Grunfeld fundan la de Rosario, Herminia Brumana, Jacobo Maguid y muchos otros la USL de Capital Federal, David Kraiselburg, José Lunnazzi y varios más la de La Plata. ${ }^{182}$ En las actas declarativas, éstos vierten opiniones compartidas sobre la propuesta constructiva que representan. ${ }^{183} \mathrm{Al}$ mismo tiempo, aparece la Unión de Mujeres Socialistas Libertarias (UMSL) de Rosario, agrupación exclusivamente formada por mujeres, impulsada por Ana Piacenza. Los primeros meses de 1946 son el momento de la apuesta fuerte por motivar la movilización de las mujeres en clave diferenciada de

\footnotetext{
${ }^{182}$ La figura de David Kraiselburd, aparece permanentemente referido en las fuentes si bien no como militante activo del anarquismo, sí en empresas que sostienen y acompañan las agencias de aquellos. Fue director del diario El Día de La Plata, maestro, director e inspector de escuelas en la provincia de Buenos Aires, abogado y escritor. Entabló una amistad entrañable desde los tiempos universitarios con Lunazzi y Grunfeld.

${ }^{183}$ Bordagaray, M. E. "Anarquismo en la Argentina. Repertorios organizacionales y de acción colectiva en el movimiento libertario, 1935-1955", en Repertorio Americano, Segunda Nueva Época, volumen 21, Costa Rica, octubre de 2011
} 
la de los hombres y el escenario político que lo habilita es el debate por la sanción de los derechos políticos de las mujeres. Iris Pavón refuerza en estos años su oposición a las formaciones puramente femeninas y profundiza su idea de una maternidad liberadora de los hombres como base para la futura sociedad libre. Herminia Brumana, ahora editora y responsable de la página dedicada a la mujer en Reconstruir, habilita la pluralidad de voces que hemos identificado como contrapuestas. ${ }^{184}$ Estos temas serán abordados en profundidad en el capítulo 3.

Nos interesa plasmar aquí una percepción con respecto a la figura de Herminia y su entorno en tiempos de fuerte represión y persecución política sobre sus “compañeros" de ideas. Casada con Juan Antonio Solari, nunca dejó de ejercer la docencia ni de escribir sus inquietudes en la prensa popular. A diferencia de sus compañeras, no sufre en estos años ni de la persecución o cárcel ni de apuros económicos. Su matrimonio con el dirigente socialista, su relación con los círculos culturales burgueses y su participación en la prensa popular, pudieron constituir elementos de peso para no relacionarla directamente con las organizaciones anarquistas. Por otro lado, en los años en que Piacenza y Pavón narran sus desventuras carcelarias, Brumana relata sus viajes por Estados Unidos en compañía de su esposo y describe las bondades de la vida de las mujeres norteamericana en cuanto a la vida social y el cuidado compartido de sus hijos en manos de las baby sitter. Es decir, el entorno desde el cual escriben es diametralmente opuesto. Brumana es una figura pública, reconocida en los ambientes literarios e intelectuales, así como también en la docencia y por la prensa masiva gracias a sus continuas escrituras. Pavón y Piacenza serán reconocidas en la posterioridad, de la mano de las acciones reivindicativas de grupos feministas que ven en estas mujeres ejemplos de lucha y resistencia.

En otro orden de cosas, así como no todas las mujeres libertarias perciben de la misma manera el rol de las mujeres en la lucha política y sus significados, el envejecimiento en las trayectorias nos permite ver también el viraje en los repertorios discursivos, pasando de un lugar "innovador" y disruptivo en relación al hegemónico en el campo, hacia uno conservador y concordante con el sostenido por los dominantes del mismo campo. Es en ese momento cuando quienes actúan

\footnotetext{
${ }^{184}$ Por ejemplo, el trabajo de Scarzanella, E. (2009). "Mujeres y producción/consumo cultural en la Argentina peronista: las revistas de la editorial Abril", en Anuario de hojas de Warmi, № 14, 1-23. 
nucleados en la FACA replantean sus estrategias de acción política orientando sus apuestas hacia el fortalecimiento de los grupos ya comprometidos con el ideario libertario y abandonando los intentos por ampliar la convocatoria hacia todos los sectores que se oponen al peronismo-fascismo. Y es allí, también, cuando la apelación a las mujeres desde una perspectiva que contempla los intereses de ellas como tales y acercándose a una perspectiva liberadora cercana al feminismo, es suplantada por otra mucho más conservadora en cuanto al rol de la mujer y su lugar en la lucha social y política. Herminia fallece de cáncer en el año 1954. Iris luego de una larga enfermedad renal, muere en 1951. No hemos hallado rastros de escritos o militancia libertaria por parte de Ana con posterioridad a 1951, aunque fallece en 1972. Los hombres sobreviven ampliamente al período estudiado y sus actividades siguen bifurcándose por caminos heterogéneos, pero siempre ligados a la militancia por "la idea".

Resta una mención sobre algunas personas que, en tiempos del peronismo, aparecen organizando y sosteniendo los "frentes" de disputa abiertos por el anarquismo. Entre las mujeres, Concepción Fernández (alias Andrea Zumarán) escribe en la página cultural de Reconstruir. Según consigna Guzzo,

"Militante anarquista, escritora, poeta. Hija de inmigrantes españoles de Galicia, llegó a la Argentina siendo muy pequeña, aunque se desconocen las fechas de su nacimiento y arribo al país. Comenzó a trabajar como planchadora pero luego adoptó la profesión de librera a domicilio. (...) Actuó en el ambiente editorial e intelectual de las décadas de 1920 y 1930. Como militante anarcofeminista colaboró asiduamente en La Protesta, Acción Libertaria y Reconstruir utilizando el seudónimo de Adriana Zumarán (nombre de la novela de Carlos Alberto Leumann). También colaboró en el quincenario antimilitarista Bandera Negra". ${ }^{185}$

Otras mujeres como Emilia Goyena y Diana Manso también participan en Reconstruir en estos años. Carecemos de datos biográficos sobre ellas.

${ }^{185}$ Guzzo, María Cristina (2014). Libertarias..., op. cit. 
Entre los hombres, merecen una mención las figuras de Luis Danussi y Floreal Ferrara: el primero abocado a la causa obrera; el segundo, al movimiento estudiantil universitario. Las referencias a Danussi comienzan para nosotros con la mención de sus compañeros Jacinto Cimazo y José Grunfeld, quienes le dedicaron un libro biográfico, en el que también recopilan testimonios de otros compañeros sobre su persona. ${ }^{186}$ Nacido en Bahía Blanca, en 1913, crece en una familia de inmigrantes italianos en los que la lectura y la crítica al sistema imperante eran constantes. Empleado en el taller metalúrgico de sus dos hermanos mayores, vive en la ciudad ya agitada de fines de los años 20, en que las disputas y los discursos callejeros convertían los domingos pueblerinos en mitines políticos y tribuna de ideas contestatarias. ${ }^{187}$ Perseguido luego del golpe de Uriburu por sus actividades sindicales y en sintonía con el grupo "antorchista" dentro de las tendencias libertarias, se instala en Rosario. Vuelve a Bahía Blanca actuando en la solidaridad con España y miembro de la recién fundada FACA. Nuevamente, huirá siendo perseguido por sus actividades de propagandista de la causa republicana. En Buenos Aires, junto a su amigo y coterráneo Fernando Quesada, organiza la parte técnica del Servicio de Propaganda España, editando la revista Documentos Históricos de España. Participa ininterrumpidamente en el gremialismo gráfico, desde su ingreso en los talleres Estampa en 1939. Escribe y dirige varias publicaciones como Acción Libertaria, Reconstruir, Solidaridad Obrera, hombre de América y El Obrero Gráfico. Fue detenido en tiempos del peronismo y retoma la actividad sindical una vez derrocado el régimen. A lo largo de su trayectoria, seguramente limitada por las cuestiones familiares y laborales que hemos identificado en este capítulo para los/las militantes libertarios, puso énfasis en el trabajo de construcción sindical, en el mundo del trabajo y en la educación de estos mismos sectores. Muere en Buenos Aires1978.

\footnotetext{
${ }^{186}$ Cimazo, Jacinto y Grunfeld, José (1981). Luis Danussi: en el movimiento social y obrero Argentino (1938-1978). Buenos Aires, Ed. Reconstruir. Otros trabajos que nombran a Danussi son López Trujillo, Fernando (2005). Vidas en rojo y negro..., op. cit. Tarcus, Horacio (2006). Diccionario..., op.cit.; Contreras, Gustavo (s/d) "De todos modos las rotativas pararon. La huelga de obreros gráficos, 1949", en http://www.historiapolitica.com/datos/biblioteca/contreras1.pdf; Ceruso, Diego (2012). "La izquierda y la organización sindical en el lugar de trabajo, 1920-1940", en Revista Archivos del Historia del Movimiento Obrero y la Izquierda, $\mathrm{N}^{\circ} 1$. Entrevista a Luis Dannusi, Archivo de Historia Oral. Buenos Aires, Universidad Torcuato Di tella

187 Sobre el juego callejero en la década del 20, ver González Aleman, Marianne (2012) ”El conflicto callejero y el derecho de reunión en Buenos Aires durante la segunda presidencia de Irigoyen" en POLHIS, Año 5, № 9.
} 
Por último, citamos a Floreal Ferrara, quien es referido por las publicaciones Revista Americana de Educación, Acción Libertaria y Reconstruir como ejemplo del joven militante anarquista actuante en el anarquismo en tiempos de resistencia al peronismo. Puntualmente en Reconstruir, aparece su nombre y apellido como corresponsal responsable de narrar los sucesos diarios de la cuestión universitaria en La Plata. En ese momento, estudia la carrera de Medicina en la universidad local y milita en su centro de estudiantes. También realiza reportajes a importantes figuras del anarquismo local. Sin embargo, su figura se pierde de vista en la prensa libertaria alrededor de 1948. Sobre Floreal Ferrara, Svampa ha escrito:

"Médico sanitarista de larga trayectoria, que se reconoce como discípulo de Ramón Carrillo; peronista de toda la vida, con una indudable vocación libertaria; hombre ligado históricamente a los sindicatos, muy especialmente a partir del periodo de la resistencia peronista; Ferrara fue también dos veces Ministro de salud en la provincia de Buenos Aires, bajo las gobernaciones de Oscar

Bidegain (entre 1973-1974), y Antonio Cafiero (entre 19871988)". 188

Es de nuestro interés evocar esta figura puesto que las fuentes anarquistas hablan de él como uno de sus más comprometidos militantes. Sin embargo, como él lo narra en la entrevista citada, luego de 1951, comienza a mirar al peronismo con otros ojos. Nacido en Punta Alta, en 1923, hijo de un viejo militante anarquista de origen yugoslavo y excelente alumno, se traslada a La Plata, donde se recibe en el año 1950. En estos años abandona las filas anarquistas, ya ejerciendo la profesión médica conoce a Ramón Carrillo y su obra. Explica de esta manera su incondicional apoyo a Perón:

"Yo siempre dije que instalar doscientos treinta hospitales, sesenta mil camas más de las que teníamos, eso es una revolución. Y a esa revolución yo la llamé "la revolución de la capacidad instalada", porque era auténticamente producir una gran revolución en el país. No solamente porque produce una revolución en la atención de los

\footnotetext{
${ }^{188}$ Svampa, Maritella (2010). Certezas, incertezas y desmesuras de un pensamiento politico: conversaciones con Floreal Ferrara. Buenos Aires, Biblioteca Nacional. Pág. 7 
enfermos, de los enfermos comunes; sino que hace una revolución en los enfermos mentales, él es el creador de grandes hospitales, enormes... con enorme significación". 189

A partir de allí, Ferrara resultará una figura ineludible para quienes evocan la obra sanitaria y de atención primaria salud en los sucesivos gobiernos peronistas. Para nuestro trabajo, la militancia de Ferrara será visibilizada en torno a su experiencia de militancia estudiantil.

\section{Consideraciones finales}

El objetivo de este capítulo fue transitar en la diversidad de las trayectorias biográficas libertarias. Según refiere Latour:

"Así como los actores constantemente son llevados a participar en la formación y destrucción de grupos (...) también se dedican a proveer explicaciones polémicas, de sus acciones así como de las de los demás. Cada entrevista, narración y comentario, por trivial que parezca, proveerá al analista un conjunto desconcertante de entidades para dar cuenta de los cómo y los por qué de cualquier curso de acción. Los científicos sociales se quedarán dormidos mucho antes de que los actores dejen de inundarlos de datos". 190

Desde ese punto de partida, nuestro primer acercamiento a estos "nombres", a estos sujetos/actores, parte de haber focalizado en los agrupamientos u organizaciones políticas del movimiento anarquista. Es decir, la identificación de cada una de estas individualidades, proviene de haberlas observado en primer lugar en su rol/identificación con las ideas libertarias. A partir de allí, nuestro recorrido pivotea entre las agencias individuales y colectivas, puesto que nuestro eje como

\footnotetext{
${ }^{189}$ Ibídem, Pág. 31

${ }^{190}$ Latour, Bruno (2008). Reensamblar lo social..., op. cit., pág. 75. 
observadores se establece en la participación de estos actores dentro de los colectivos libertarios. Es decir, nuestra mirada se aleja de la etnografía para recuperar (recortar) la gran cantidad de "datos" que ellos nos brindan a partir del registro de sus propias voces y/o acciones. Sin embargo, creemos que la individualización y la visibilidad que le hemos dado a ciertos nombres dentro de esos colectivos, resulta uno de los aportes más importantes de la presente investigación. Por otro lado, las particularidades en las experiencias tanto de los hombres como de las mujeres que sostuvieron este amplio abanico de estrategias de acción política, contribuye a clarifica y echar luz sobre un período de la historia que resulta oscura en relación a las agencias ácratas. Es decir, no sólo hemos recuperado nombre, personas, sino también grupos, dinámicas y estrategias colectivas que contienen y se construyen en base (pero no solamente) a esas estrategias individuales. Sin duda sus roles como organizadores, las múltiples identidades y lazos que cada uno estableció con sus profesiones, en sus redes familiares y sus trabajos, explican una dispersión fundante y sobre la cual es necesario recalar para comprender el apartado siguiente.

Sin abandonar definitivamente las perspectivas bourdieuanas, al fin y al cabo, a lo largo de nuestro recorrido hemos visibilizado las posiciones que las y los libertarios han ocupado en el campo político del anarquismo argentino. Podemos esbozar que tanto Ana Piacenza como Iris Pavón y Herminia Brumana, han participado en estos espacios siempre desde un lugar subordinado al de los hombres. Sin embargo, los recorridos biográficos dan cuenta de que esta subordinación no es homogénea, y en general se relaciona con las experiencias, identificaciones y eventualidades que cada una de ellas contienen en sus biografias. El capital social, cultural, profesional, pero también sus relaciones personales, sus familias y lugares de origen, las posibilidades laborales, la cárcel o el nacimiento de los hijos, son variables que definen directamente el posicionamiento tanto de los hombres como de las mujeres en ese campo político, el del anarquismo de los años 30/40.

Estas variables, aparentemente "secundarias" para el estudio de un movimiento político o de una biografía de un militante, resultan indispensables para abordar las vidas de aquellas que como Iris Pavón y Ana Piacenza han sido ignoradas por los relatos historiográficos y por su propio movimiento. Como ya lo adelantamos, Iris Pavón muere en el año 1951 y Ana Piacenza comienza a alejarse de su militancia 
libertaria durante los años peronistas. Grunfeld, Maguid y Lunazzi participarán activamente en el hasta bien entrados los años 90 sin perder su posición dominante ni su rol organizador. La lectura desde estas perspectivas nos permite visibilizar estas particularidades, que en definitiva y como hemos demostrado en el presente capítulo, son las que definen las posibilidades de la acción militante por las ideas libertarias.

\section{Capítulo 3}

INTERPELAR A LAS MUJERES, REDEFINIR OTREDADES

Como ya hemos adelantado en los capítulos precedentes, las mujeres fueron sujeto de disputa por parte del colectivo libertario. La organización de las anarquistas durante la década del '30 -fogueada al calor de acciones tales como la solidaridad con los presos políticos, la lucha antifascista y gremial- fue quebrada durante el peronismo en una coyuntura que cambió dramáticamente el escenario político-social.

Así, las controversias internas acerca del rol de la mujer para el anarquismo en la transformación de la sociedad y las formas de integrarlas al movimiento o de organizarlas, se entrecruza con la llegada del peronismo como movimiento de masas. El peronismo, por su parte, le disputa al anarquismo los sujetos a los que históricamente había convocado.

Frente al nuevo panorama planteado por el peronismo, las mujeres anarquistas intentaron dar continuidad a las formas organizacionales que habían animado en los 30, particularmente en algunos ámbitos locales donde ciertas animadoras resultaron figuras claves para esa organización. Así, puede comprenderse la formación, en 1946, de las agrupaciones mixtas llamadas Uniones Socialistas Libertarias (USL) y la de una agrupación exclusivamente de mujeres como la Unión de Mujeres Socialistas Libertarias (UMSL).

En este sentido, la noción de controversia sirve para pensar en primer lugar, los debates dentro del mismo anarquismo respecto de los temas vinculados a las 
mujeres, debates que no siempre son explícitos sino que están larvados a lo largo de sus producciones y acciones. Ahora bien, en el marco del peronismo, la noción de controversia también resultará central para comprender de qué modo el anarquismo intentó disputar un espacio al peronismo en relación con los temas vinculados las mujeres. Desde el periódico Reconstruir, es posible dar cuenta de los debates que dieron los anarquistas y que, en algunos casos, implicaron moderar algunas de las posturas asumidas en los '30, particularmente, las vinculadas a la noción de ciudadanía de las mujeres.

Para ello, siguiendo la apuesta metodológica por pensar las relaciones en clave de controversias, estableceremos diferentes escenarios en los que la actuación de las libertarias se dirime en tiempos del peronismo en el poder. Así, observaremos controversias diferenciadas en torno a diferentes temas caros a las apuestas anarquistas en estos años: con el Estado y el movimiento peronista debatirá acerca de la naturaleza de la participación política que éste propone para las mujeres y que el anarquismo considera dirigistas, subsidiarias, totalitarias y misóginas. Por otro lado, describirá las dificultades que el sufragismo presenta en estos tiempos en los que va de la mano de ideas más conservadoras de lo que fueron su raíz histórica y en el que el voto le es reconocido a las mujeres en el marco de un sistema que el anarquismo considera "pseudo democrático" liderado por el peronismo. Teniendo en cuenta las características del contexto de movilización política femenina durante el peronismo, las mujeres recobraron un papel crucial como sujetos revolucionarios para el anarquismo. En ese caso, resulta útil indagar cómo para el anarquismo fue necesario construir alocuciones contestatarias al discurso que modelaba el peronismo.

Las tensiones y diferencias que percibimos en torno a estos tópicos tienen que ver con la naturaleza de la militancia y las ideas ácratas que también están en disputa y contribuyen a que aparezcan distintos temas relacionados a los que son objeto de disputa con el peronismo. De este modo, conceptualmente, nos interesa rescatar no tanto una identidad fija del anarquismo en torno a las mujeres sino la movilidad y la dinámica en los procesos de construcción del movimiento. A partir de ciertos núcleos discursivos y de acción política, las mujeres anarquistas, según nuestra interpretación, “(...) determinaron un conjunto de actores y definieron sus 
identidades de tal modo que se situaron a sí mismos en un punto de paso obligado de la red de relaciones que estaban construyendo". ${ }^{191}$

Nuestra hipótesis resulta de considerar que, mediante la crítica a las políticas públicas del gobierno en torno a la maternidad y al voto femenino propugnado por el peronismo, las anarquistas trataron de resultar indispensables al colectivo "mujeres" definiendo su naturaleza y sus problemas, y sugiriendo que éstos podían resolverse si los actores negociaban con su particular propuesta de cambio y de interpretación -a la sazón, opuesta al discurso hegemónico (el del

Estado) que define las nociones de "voto femenino".

En primer lugar, presentaremos las percepciones generales de los colectivos libertarios sobre el Estado peronista y las políticas públicas llevadas adelante por un estado "totalitario En segundo lugar, abordaremos las discusiones que en tono de controversia las anarquistas de Reconstruir establecen con los sentidos que el peronismo "impone" sobre el sufragio femenino, la participación política de las mujeres $y$ el feminismo. Por último, visibilizaremos los repertorios organizacionales que los colectivos libertarios construyen como estrategia de "interesamiento" hacia las mujeres.

\section{Polémicas con las políticas públicas peronistas}

Marcela Nari caracterizó el período que corre entre 1890 y 1940 por una gradual reducción de la natalidad que se combinó con un incremento en la tasa de mortalidad infantil lo cual generó una sensible preocupación desde distintas áreas del Estado y la sociedad civil. En este marco, la autora diferencia analíticamente dos períodos en relación a qué cuestiones acerca de la maternidad centralizan las políticas públicas entre 1890 y 1940. El primero, entre 1890 y 1920, puede distinguirse por la elaboración de políticas públicas tendientes a la maternalización

${ }^{191}$ Callon, Michelle (1986), op.cit. S/N 
de las mujeres; y el segundo, entre 1920 y 1940, caracterizado por medidas que hacían eje en la politización de la maternidad. ${ }^{192}$

Estos estudios fueron continuados por un debate que se suscitó en relación con el peronismo. En efecto, según ha subrayado María Teresa Acosta, en las investigaciones pueden distinguirse tres vertientes. ${ }^{193}$ Por un lado, las autoras que consideran que las políticas públicas del peronismo fueron pronatalistas, es decir, aumentaron -a través de distintas medidas- la tasa de natalidad. ${ }^{194}$ Otras posturas, señalan que esa propuesta menguó y fue remanente durante ese lapso en el que se distinguen con más solidez las líneas promaternalistas, es decir, las líneas que reconocían un interés público en mejorar la calidad de cuidados de los hijos, mas no su aumento. ${ }^{216}$ Finalmente, aunque consideraron que era una veta incipiente y no completamente desarrollada por distintos problemas (presupuestarios, personal capacitado, etc.), se pueden mencionar las políticas de crianza estatizada, vale decir, las que vieron en las instituciones estatales el reemplazo de las funciones que las madres y/o las familias en conjunto no cumplían o lo hacían insatisfactoriamente. ${ }^{217}$ En este último caso, los hogares escuela, las colonias de vacaciones y las escuelas hogar son emblemáticos de esta postura.

Esta discusión, como bien señala Acosta, tiene como mar de fondo la definición del Estado durante el peronismo y su catalogación -irresuelta- en si fue un Estado Benefactor -a la usanza europea- o si fue un momento de democratización del bienestar -con marcas singulares presentadas por el peronismo-.

Estos debates historiográficos, con todo, evidencian prismas de lectura que, en muchos casos, estuvieron presentes entre los actores del momento entre los cuales estuvo el movimiento anarquista y, en especial, las mujeres libertarias.

\footnotetext{
${ }^{192}$ Nari, Marcela (2004). Políticas de maternidad..., op. cit.

${ }^{193}$ Acosta, María Teresa (2012), "Políticas de maternidad durante el período peronista: quiebres y continuidades en las relaciones de género." Trabajo de Especialización, Maestría en Ciencias Sociales y Humanidades, con mención en Historia. Inédito.

194 Torrado, Susana. (2003). Historia de la familia en la Argentina moderna (1870-2000). de la Flor. Di Liscia, María Herminia (2000). "Maternidad y discurso maternal en la política sanitaria peronista”, en Di Liscia, et al, Mujeres, maternidad y peronismo, Santa Rosa, Fondo Editorial 
El anarquismo, en particular, no tuvo matices en sus lecturas respecto de las políticas del peronismo que, en particular respecto de la maternidad, ocuparon buena parte de sus consideraciones durante el período. En efecto, a partir de 1946, con la aparición del periódico Reconstruir, queda manifiesto que el anarquismo identifica al peronismo con dos líneas de intervención. Por un lado, las ideas más conservadoras de la maternidad, esto es, la madre cuya función se remite a hacer

Pampeano. 39-51. Bianchi, Susana (2000). "Las mujeres en el peronismo (Argentina 1945-1955)", en: Duby, G., y Perrot. M. (dir.) Historia de las Mujeres, El siglo XX, Madrid, Taurus.

216 Barrancos, Dora (2002), "Iniciativas y debates en materia de reproducción durante el primer peronismo (1946-1952)" en Seposal, Salta. Ramacciotti, Karina Y Valobra, Adriana (2003). Generando el peronismo: estudios de cultura, política y género, 1946-1955. Proyecto Editorial. Biernat, Carolina y Ramacciotti, Karina (2011). "La protección a la maternidad de las trabajadoras en Argentina: aspectos legales y administrativos en la primera mitad del siglo XX", en Hist. ciênc. saúde-Manguinhos, 18 (supl. 1), 153-177.

217 Ramacciotti, Karina y Valobra, Adriana, (2004) "Plasmar la raza fuerte...' Relaciones de género en la propaganda sanitaria de la Secretaría de Salud Pública de la Argentina: 1947-1949, en Karina Ramacciotti y Adriana Valobra (compiladoras), Generando el peronismo. Estudios de cultura, política y género, Proyecto Editorial, Buenos Aires

nacer a los futuros soldados de la patria - una política pronatalista- y, la otra, la vinculada a la visualización de intervenciones del estado que iba en pos de avasallar los derechos de esas mismas madres y sus hijos en políticas de crianza estatizada que, en la visión libertaria, fueron catalogadas como políticas totalitarias que a pesar de no ser extendidas, alarmaron a estos contemporáneos por lo que consideraban sus parecidos de familia respecto del nazismo.

La ocasión para iniciar la controversia tuvo lugar, precisamente, durante el debate parlamentario acerca de la implantación de un sistema de preconscripción. Por este medio, el Estado asumía la educación de los niños a partir de los 12 años con el fin de formarlos con vistas a ingresar a las filas de los ejércitos del futuro. ${ }^{195}$ La posibilidad de que el Estado lo aplicara fue considerada un indicador de la naturaleza totalitaria y fascista del gobierno peronista.

\footnotetext{
${ }^{195}$ El debate público sobre la incorporación de jóvenes y adolescente en un sistema educativo orientado a formarlos en prácticas pre-militares, centradas en la educación física y los valores de la defensa nacional a través del servicio a la patria, se inicia luego de que la "preconscripción" es mencionada en las Leyes $\mathrm{N}^{\circ} 12911$ y $\mathrm{N}^{\circ} 12913$ de ratificación de los decretos-leyes del período comprendido entre 1943 y 1946, donde figura como artículo o inciso dentro de un artículo de los Decretos N N $^{\circ} 29.375 / 44$ de la Ley Orgánica del Ejército y el art. 28.603/45 de la Ley Orgánica para el personal militar de aeronáutica. Cucuzza, H. R. y Acevedo, C. (1997). Estudios de historia de la educación durante el primer peronismo, 1943-1955. Editorial los libros del riel.
} 
Desde el periódico Reconstruir, se asumió que "las madres" que apoyaran esta medida o la aceptaran sin reparos serían aquellas engañadas por el aparato peronista, obnubiladas por la propaganda oficial. ${ }^{196}$ Reconstruir generaliza y da por hecho el apoyo de "las madres" a esta medida. Pero este apoyo, el medio libertario lo entiende como devenido del engaño ejercido por la propaganda estatal, que por medio de la manipulación y la demagogia coloca a las mujeres como:

“(...) cómplices, sin saberlo, del futuro sacrificio de sus hijos (...)”. ${ }^{197}$ Si bien admiten que el apoyo al peronismo se da entre las mujeres de las clases populares apuestan a que ellas, por ser madres, se opondrán definitivamente a tal cuestión cuando conozcan los verdaderos intereses que se esconden tras los proyectos de preconscripción. ${ }^{221}$ De esta manera, las "madres" apoyan al gobierno peronista porque desconocen o ignoran las profundas raíces del régimen. La educación y el conocimiento profundo de la realidad en la que están inmersas, puede dar luz sobre estas mujeres-madres. De allí a la oposición al régimen, habría un solo paso.

Así, si bien las anarquistas admiten que el apoyo al peronismo se da entre las mujeres de las clases populares; apuestan a que ellas, por ser madres, se opondrán definitivamente a tal cuestión cuando conozcan los verdaderos intereses que se esconden tras los proyectos de preconscripción:

\section{"No creemos que las madres proletarias que en su trágica inconciencia aplauden al líder y a su consorte, admitirían de buena gana que sus hijos fueran material de experimentación del totalitarismo, si supieran que eso es en realidad lo que va a ocurrir". 198}

De esta manera, las "madres" apoyan al gobierno peronista porque desconocen o ignoran las profundas raíces del régimen.

En esta línea, Iris Pavón plasma en Reconstruir sus opiniones con respecto al peronismo, la mujer $\mathrm{y}$, fundamentalmente, la maternidad como eje para el cambio

\footnotetext{
${ }^{196}$ Reconstruir, $\mathrm{N}^{\mathrm{o}} 2$, julio de 1946

${ }^{197}$ Reconstruir, $\mathrm{N}^{\mathrm{o}} 12$, febrero de 1947. Pág. 10

${ }^{221}$ Ibídem.

${ }^{198}$ Ibídem.
} 
social. En sus escritos denuncia la propaganda peronista y los métodos utilizados en relación con la educación y la infancia. Según Pavón, estos métodos coadyudaban a mantener a las mujeres en un lugar conservador y subsidiario, mientras que el Estado se hacía cargo de la educación de los "futuros soldados de la patria”. Según entendía, en el Primer Plan Quinquenal, por medio del control del tiempo libre, de las formas y los contenidos educativos y en la excesiva exhortación al entrenamiento físico de los jóvenes había un intento de militarización de los niños y los jóvenes.

La peor consecuencia de esa práctica era que el objetivo sería precisamente la guerra y el mantenimiento del orden totalitario. Estas posiciones del gobierno peronista preocuparon a esta dirigente, que afirmó:

“(...) ante la inminencia de una nueva hecatombe mundial, que adquiriría esta vez proporciones de verdadero cataclismo, no quedan terceras posiciones: o se está con la guerra o se está contra la guerra.

Deben entenderlo asi las mujeres que en verdad aman a sus hijos, y que desean evitarles la triste suerte de ser carne de cañón, sacrificada en aras del egoísmo y la ambición de los nuevos amos de la tierra". 199

Resuenan en esta intervención los ecos de otro dilema que se planteó respecto del pacifismo y las formas de intervención del anarquismo, particularmente en la movilización femenina. Como ha señalado Manzoni, a diferencia de las posturas de fines del siglo XIX -por ejemplo, en La Voz de la Mujer-, que explicitaban la ruptura con las relaciones de género impuestas en la época y, con ella, un nuevo ideal donde la maternidad implicaba otras modelizaciones; el antimilitarismo posterior a la Primera Guerra Mundial conllevó "un nuevo tipo de intervención" que se posicionó

"a partir de lugares que eran considerados legitimos para las mujeres de aquella época. Aquellos lugares de los que, en muchas ocasiones, las

${ }^{199}$ Reconstruir, $\mathrm{N}^{\mathrm{o}} 2$, junio de 1946. Pág. 11 
libertarias habian renegado, del que buscaban desprenderse como mandato de pretendida obligatoriedad biológica", 200

En el contexto del peronismo, esta tesitura continúa. La identificación del peronismo con un modelo de maternidad conservador y funcional al régimen es acompañada por propuestas acerca de cómo revertir esta situación denunciada. Así, para el anarquismo, la clave para el cambio también está en la maternidad. Pavón propone como estrategia de acción una gran "congregación de madres", pues ellas representan el "corazón de la humanidad". ${ }^{201}$ En su convocatoria, entrecruza los elementos provenientes de un ensalzamiento del rol de madre como función social y de hermandad entre todas las mujeres; mientras la referencia al corazón como órgano fundamental de la humanidad se relaciona con las nociones que adscriben la existencia y la función de las mujeres a su naturaleza biológica y emocional.

Pavón interpelaba a las madres y en especial -aunque implícitamente- a las adherentes al peronismo y a la tercera posición a fin de que ellas tomaran en sus manos el curso del destino de sus hijos. El temor a una tercera guerra mundial estaba latente en el contexto de la guerra fría. ${ }^{202}$ La distancia de Perón respecto de Estados Unidos había quedado discursivamente plasmada en la campaña electoral cuando el eslogan "Braden o Perón" fue utilizado como un latiguillo antiimperialista y nacionalista. Sin embargo, planteaba una distancia y beligerancia semejante para con el sistema soviético y los países bajo su égida. De allí que existieran temores de que en un futuro conflicto, Argentina pudiera estar inmiscuida.

Para ello, la militante anarquista contrapone la maternidad al color partidario:

"a la madre, que no es peronista ni antiperonista porque su sola y suprema condición la ubica por encima de lo circunstancial, a la madre de todos los niños argentinos nacidos y por nacer (...)

\footnotetext{
200 Manzoni, Gisela (2012) "Madres anarquistas, hijos revolucionarios. La maternidad como estrategia de intervención pública", ponencia presentada en Congreso Latinoamericano de Historia de las Mujeres, San Juan, Argentina, 20 a 22 de septiembre.

${ }^{201}$ Reconstruir, $\mathrm{N}^{\circ} 21$, octubre de 1947.

${ }^{202}$ Hobsbawm, ERIC (1998), Historia del Siglo XX, Editorial Siglo XXI,
} 
¿Permitiréis vosotras, por ignorancia, por ingenuidad, por cobardía, que con nuestros hijos se repita la experiencia trágica que ha desgarrado a Europa?", ${ }^{203}$

Sólo la madre iluminada en valores morales era capaz de salvar al pueblo argentino de esa tragedia:

\begin{abstract}
"La Madre, sólo la Madre, puede y debe dar respuesta categórica y definitiva. Y en ella confiamos para salvar, en el niño, todo el futuro del país y del mundo".228
\end{abstract}

Para Pavón, es función de las madres evitar que sus hijos formen los ejércitos de los estados belicistas. Para ello se necesitan madres lúcidas y decididas a sostener los ideales de la libertad. La clave sigue siendo el amor maternal, individual y universal, de cada madre por sus hijos y de todas las madres por los hijos de la humanidad.

En resumen, para el proyecto anarquista de Pavón, la mujer formaría parte de la nueva sociedad asumiendo el papel de educadora de sus hijos, en su rol revolucionario como madre iluminada e iluminadora, y no a través de su propia participación en la cosa pública. La educación moral de las mujeres que estas anarquistas proponen se construye en clave de la diferencia. Hay una continuidad del ideario ácrata en este punto, ya que estas ideas acerca de la maternidad no son nuevas para el anarquismo. Marcela Nari ha analizado de qué manera las anarquistas reflotaron una mirada más bien conservadora de las mujeres que se contraponía a otras lecturas sobre sus roles y destinos sociales. ${ }^{204}$ Coincidimos con Manzoni cuando plantea que la interpelación de las anarquistas con respecto a las mujeres se posicionó a partir de lugares que eran considerados legítimos para las

\footnotetext{
${ }^{203}$ Reconstruir, $\mathrm{N}^{\circ} 12$, febrero de 1947. Pág. 10

${ }^{228}$ Ibídem.

${ }^{204}$ La autora diferencia, por ejemplo, entre aquellas posiciones que plantean la "diferencia" pero en una relación de complementariedad con los hombres y aquellas que exaltan los tributos femeninos sobre los masculinos, con lo cual invierte la jerarquía patriarcal tradicional. Pero, según la autora, en definitiva estas ideas terminan reforzando una identidad femenina vinculada y definida por la maternidad. Véase Nari, Marcela (2004). Políticas de maternidad...op. cit.
} 
mujeres de aquella época: la maternidad sigue siendo ese lugar que homogeniza a todas las interpeladas. ${ }^{205}$

De este modo, el anarquismo no escapó a las mismas tensiones respecto de la definición de la mujer que se han encontrado en el discurso peronista. Numerosas investigaciones han concluido en la existencia entre los años 20 y 30, de nuevas moralidades en relación a la sexualidad femenina, la concepción y la maternidad. Si bien seguía siendo su "función natural", estadísticamente se observa una merma en los nacimientos: las mujeres tenían menos cantidad de hijos en relación a las de fines del Siglo XIX. Del mismo modo, si bien el matrimonio era una situación también naturalizada para las mujeres "de bien”, se realizan a una edad más avanzada. Estos cambios en la vida de las mujeres, fueron acompañados por ciertos discursos (médicos, estatales, científicos y jurídicos) que adscribían fuertemente la función de la mujer al de la maternidad. En los mismos años, a estos discursos conservadores con respecto al rol de las mujeres, aparecen en escena otros contrapuestos, como los de la eugenesia en clave anarquista que proponen el control de la natalidad a través del empoderamiento de las mujeres y la maternidad consciente y voluntaria. ${ }^{206}$.

\section{Sufragismo, feminismo y democracia en cuestión}

El argumento de las dos esferas (pública y privada) ha sido fundante para la modernidad y base para el origen de la exclusión de las mujeres de la política y su confinamiento a la domesticidad. ${ }^{207}$ Sin embargo, es necesario situar el desarrollo posterior de esa exclusión, cuya complejidad requiere análisis específicos de los procesos y del desarrollo histórico que enmarcan la historia misma de las

\footnotetext{
${ }^{205}$ Manzoni, Gisela (2009). "Antimilitaristas y libertarias. La postura de las mujeres anarquistas ante el militarismo." I Jornadas CINIG de Estudios de Género y Feminismos Teorías y políticas: desde el Segundo Sexo hasta los debates actuales, 29 y 30 de Octubre.

${ }^{206}$ Ledesma Prietto, Nadia (2012). "Apuntes sobre la eugenesia y la libertad sexual en el discurso de dos médicos anarquistas. Argentina, 1930-1940”, en Nomadias, № 16.

${ }^{207}$ Luna, Lola (1994). "Estado y participación política de mujeres en América Latina: una relación desigual y una propuesta de análisis histórico", en León, M. (coord.) Mujeres y participación política. Bogotá, Tercer mundo Editores.
} 
relaciones de género. ${ }^{208}$ Precisamente, la exclusión de las mujeres del sistema político-público dio lugar a que históricamente emergieran movimientos feministas $\mathrm{y}$ de mujeres, que reivindicaron el voto y el acceso a sus derechos civiles y sociales alcanzando planteos radicalizados que reformulaban la ciudadanía tal como la pensó el Estado moderno-masculino-individual. ${ }^{209}$

Según Maxine Molyneux, desde los comienzos de las luchas de las mujeres por la ciudadanía, los "atributos especiales" de ellas fueron esgrimidos tanto a favor como en contra de que fueran incluidas en las cuestiones públicas y políticas.

Así, perdura una contradicción entre los principios de "igualdad y diferencia" que no fue resuelta y que se cristaliza en la relación mujer-feminidad y biología. ${ }^{210}$

El peronismo no fue ajeno a esa tensión y resaltó la legitimad de las mujeres para acceder al sufragio, haciendo especial énfasis en sus bondades maternales. Como lo adelantamos en el apartado anterior, en la mayoría de los estudios se coincide en señalar que el peronismo se inscribió en la ideas del maternalismo político o que éste predominó respecto de otros giros menos convencionales y que, desde allí, esgrimió las nociones sufragistas que llevaron luego a la sanción de la ley de derechos políticos femeninos. ${ }^{236}$ Las ideas y luchas del feminismo casi no fueron enunciadas en los ámbitos parlamentarios. La aptitud de éstas para ser madres fue el elemento sobre el cual se construyeron las ideas de la representación femenina en los discursos legislativos. Sin embargo, otras investigaciones, han señalado algunas torsiones. Así, por ejemplo, respecto del discurso de Evita sobre el sufragio femenino se afirma que presentó una heterogeneidad que ha sido poco analizada en las investigaciones. Corriéndose de lo que llaman interpretaciones instrumentales respecto de Evita, esos estudios afirman que la líder matizó el rol

\footnotetext{
${ }^{208}$ Scott, Joan (1990). "El género, una categoría útil para el análisis histórico", en Amelang, James y Nash, Mary (eds.). Historia y género: las mujeres en la Europa moderna y contemporánea, Edicions Alfons el Magnanim.

${ }^{209}$ Amorós, Celia (1994) Historia de la teoría feminista. Instituto de investigaciones feministas de la Universidad Complutense de Madrid.

${ }^{210}$ En palabras de Molyneux: "Mientras que los que se oponían a los derechos políticos de las mujeres aducían que las mujeres eran demasiado apasionadas, ignorantes o domésticas para ejercer una opinión política, sus defensores también recurrían a este lenguaje de la diferencia e invertían sus términos para defender que las virtudes 'innatas' que poseían las mujeres, como el altruismo y la moral, servirían para mejorar la vida política. Por lo tanto, la biología y la
} 
conservador de las mujeres politizándolo y marcando las profundas interrelaciones que las mujeres estaban llamadas a realizar entre lo público y lo privado. ${ }^{237}$

Ahora bien, en este contexto, la problemática sufragista se vinculó con el movimiento feminista. Para el período peronista, las sufragistas no se encontraban organizadas en grupos colectivos, sino que habían dirigido sus esfuerzos organizativos a los partidos desde los cuales algunas levantaban las banderas sufragistas, incluso feministas. ${ }^{238}$ Algunas sufragistas de nuevo cuño, como las califica Donna Guy, habrían incursionado en el peronismo; pero la mayoría de ellas se ubicaron en el radicalismo y el socialismo, incluso, las comunistas, que en los '30 se unieron a las feministas merced a su política de frentes; incorporaron una

psicología de la mujer se pusieron al servicio de la búsqueda de la igualdad”. Molineux, Maxine (2001). "Género y ciudadanía en América Latina: cuestiones históricas y contemporáneas", en Debate Feminista, $\mathrm{N}^{\circ}$ 12, 3-66

236 Bianchi, Susana y Sanchís, Norma (1988). El Partido Peronista Femenino. Buenos Aires, Centro editor de América latina.

237 Valobra, Adriana María (2010) Del hogar a las urnas. Recorridos de la ciudadanía política femenina. Argentina, 1946-1955. Rosario, Prohistoria Ediciones. Palermo, Silvana (1998). "El sufragio femenino en el Congreso Nacional: ideologías de género y ciudadanía en la Argentina (1916-1955)", en Boletín del Instituto de Historia Argentina y Americana Dr. Emilio Ravignani, $\mathrm{N}^{\circ}$ 16.

238 Valobra, A. M. (2008). "La ciudadanía política de las mujeres y las elecciones de 1951”, en Anuario del Instituto de Historia Argentina.

serie de reivindicaciones propias de este movimiento. ${ }^{211}$ Hay consenso en señalar que el sufragismo había logrado instalar la temática mientras que el peronismo logró clausurar "la sensación de injusticia que suponía la exclusión de las mujeres del derecho al sufragio". ${ }^{212}$ Es decir, el peronismo se alzó con los laureles del sufragismo al sancionar la ley.

Ahora bien, en estas discusiones se ha omitido el análisis del proceso que realizaron las anarquistas quienes resultan ser especialmente relevantes por su histórica relación de confrontación con las feministas sufragistas.

${ }^{211}$ Guy, Donna (2008). Women build the welfare state: Performing charity and creating rights in Argentina, 1880-1955. Duke University Press. Sobre las mujeres sufragistas en el socialismo y comunismo en Argentina, ver Barrancos, Dora (2011) "El Partido Socialista y el sufragio femenino, 1947-1951", en Barry, Carolina (comp.), Sufragio femenino. Prácticas y debates políticos, religiosos y culturales en Argentina y América Latina. EDUNTREF. Valobra, Adriana (2011) "Prácticas y debates sobre los derechos políticos de las mujeres en la UCR y el PCA, 19461955", en Barry, Carolina (comp.) Sufragio femenino. Prácticas y debates políticos, religiosos y culturales en Argentina y América Latina, EDUNTREF

${ }^{212}$ Valobra, Adriana (2010). Del hogar a las urnas..., op. cit. Pág. 62. 
Anne Marie Kapelli ha afirmado que históricamente las relaciones entre anarquismo y feminismo han sido nulas. ${ }^{213}$ En contraposición, la historiadora Mercedes Yusta, entre otras, resaltó las relaciones entre feminismo sufragista y anarquismo en España. Del mismo modo, discursos disruptivos con esta generalización son abordados en el presente capítulo. Dora Barrancos retoma la interpretación que las anarquistas hacen del feminismo (burgués y sufragista) y asegura que nociones como "antifeminismo del feminismo anarquista" para calificarlo son un contrasentido. No obstante, considera que existía una veta feminista en esta línea anarquista: el anclaje en la mujer proletaria, por lo que la autora lo definirá como "feminismo obrero". ${ }^{214}$ Aquí, "feminismo" es utilizado como categoría analítica que remite a la existencia de algún grado de "conciencia feminista". Resulta problemático pensar en una veta feminista porque -como también señala la autora- hay en la doctrina anarquista una negación sistemática de la especificidad de lo femenino y prevalecen los discursos masculinos sobre el problema de la mujer. $^{215}$

Si a priori establecemos, esquemáticamente y de acuerdo a la historiografía, tres diferentes tipos de anarquismos (anarco-sindicalismo, anarco-individualismo y anarco-comunismo), entendemos que también debe desnaturalizarse el concepto "anarquismo" para pensarlo en su multiplicidad. Lo mismo puede sostenerse respecto de la noción de "feminismo" que involucra posturas absolutamente disímiles. Un esfuerzo en este sentido lo realizó la misma Dora Barrancos quien vuelve a retomar el problema al analizar una "segunda etapa" de las agencias de mujeres y las cuestiones femeninas entre los anarquistas. Esta segunda etapa, iniciada al comenzar la década del $20^{\prime}$, contó con nuevas concepciones en el nivel local alimentadas por posturas libertarias internacionales. Por ejemplo, se hicieron más fuertes las ideas "limitacionistas" de la natalidad y la multiplicación de voces femeninas. ${ }^{216}$ La autora analiza en el periódico anarquista Nuestra Tribuna, las

\footnotetext{
213 Anne-Marie Kappeli (1994) “Escenarios del feminismo”, en Duby G. y Perrot M., Historia de las mujeres, tomo 8, Madrid.

${ }^{214}$ Barrancos, Dora (1996). "Mujeres de Nuestra Tribuna...”, op. vit.

215 Barrancos ha trabajado para el caso del anarquismo argentino en la línea de Mary Nash del predominio de un "feminismo de signo social". Nash, Mary "Experiencia y aprendizaje: la formación histórica de los feminismos en España”, Historia Social, n²0, 1994, pp. 151-172.

${ }^{216}$ Barrancos, Dora (1990). Anarquismo..., op. cit., pág. 275.
} 
relaciones y enfrentamientos intergenéricos con los compañeros de ideas y las intragenéricas con las feministas. ${ }^{217}$

El anarquismo, en general y desde todas sus vertientes, tuvo desde fines del siglo XIX una clara confrontación con el feminismo, especialmente el sufragista. Según una de las dirigentes más reconocidas de la década de 1920, Juana Rouco Buela, "La emancipación -bajo el punto de vista humano- 'es social'. El feminismo está de más". Rouco descreía de las ideas que las sufragistas feministas propiciaban:

“(...) por intermedio del sufragio feminista, delegando las mujeres sus intereses $y$ derechos naturales a futuras diputadas y senadoras, pueden llegar gradualmente diplomáticamente y parlamentariamente a alcanzar su emancipación”. ${ }^{218}$

Ahora bien, como hemos señalado, la bibliografía se ha concentrado en el considerado momento "clásico" del anarquismo y ha omitido reflexiones sobre otros momentos histórico. Nuestro trabajo demostrará las torsiones y virajes de estas posturas antifeministas y antisufragistas en el contexto del peronismo y nos invitará a pensar cómo, en un momento diferente, comprender las controversias generadas puede iluminar distintas posturas políticas más o menos coyunturales.

Siguiendo a Scott, entendemos que la perspectiva del género ha aportado a la historia la posibilidad de realizar nuevas preguntas, ampliar el análisis y permitir la elaboración de hipótesis que incluyan la perspectiva relacional de las vinculaciones sociales entre los sexos. ${ }^{219}$ En ese caso, resulta útil indagar cómo desde el anarquismo fue necesario construir alocuciones contestatarias al discurso que modelaba el peronismo. Asimismo, el anarquismo renovó sus prácticas políticas y empresas culturales a fin de encontrar nuevas maneras de disputar sujetos políticos como las trabajadoras que, ahora, el peronismo hegemonizaba. En particular, nos interesa en esta oportunidad analizar las opiniones de las anarquistas que participaron en el periódico Reconstruir acerca de la cuestión del voto y de la

\footnotetext{
${ }^{217}$ Barrancos, Dora (1996). "Mujeres de Nuestra Tribuna...”, op. cit.

${ }^{218}$ Citado en Ledesma Prietto y Manzoni (2010). "Pluma, aguja y barricadas...", op. cit.

${ }^{219}$ Scott, Joan (1990). “El género, una categoría útil...”, op.cit. 
ciudadanía política femenina, nociones inseparables del modo en que el movimiento consideró a las mujeres. Nuestra propuesta es descubrir cómo han sido vistas estas relaciones en el escenario historiográfico para cuestionar estos grandes discursos que atraviesan y prescriben nuestro accionar como estudiosos de la sociedad.

\section{La controversia anarquista con el sufragismo peronista}

Nuestro objetivo en este apartado es demostrar que, conforme avanzamos en el tiempo, y en particular durante el período peronista, encontramos un punto de quiebre de ese rechazo que las anarquistas prodigaron a las feministas sufragistas. En efecto, en los primeros años del período peronista y en función de dar una respuesta al sufragismo que propiciaba el gobierno con Evita a la cabeza, esta postura parecería más ecléctica durante el peronismo y marcó diferencias entre feminismo y sufragismo, cuestión en la que las anarquistas de principios de siglo parecían no reparar en detalle.

Para el período peronista, las sufragistas no se encontraban organizadas en grupos colectivos, sino que habían dirigido sus esfuerzos organizativos a los partidos desde los cuales algunas levantaban las banderas sufragistas, incluso feministas. Según Martínez Prado, la movilización contra la fórmula Perón/Quijano llegó a ser una de sus más heterogéneas articulaciones. Agrupaciones como la Federación de Mujeres Universitaria de la Argentina, la Unión de Mujeres Socialistas y la Secretaría Femenina de la Junta Coordinadora de la Unión Democrática apelaron a la memoria histórica para intervenir en el debate sobre el sufragio femenino, reconociendo las luchas feministas por la obtención de derechos y el sufragismo como movimiento que definitivamente instala la temática. ${ }^{220}$

Herminia Brumana fue quien escribió la primera nota de opinión en Reconstruir cuyo tema central era el voto femenino. Vale decir que para definir el

\footnotetext{
${ }^{220}$ Martínez Prado, Natalia (2012). "Mujeres de otra raza": la irrupción del peronismo en el activismo femenino/feminista", en Identidades, Núm. 3, Año 2 Diciembre.
} 
sujeto femenino y revolucionario del anarquismo, confrontó con lo que consideró su antítesis: la noción de "ciudadanía" que proponía el peronismo al identificarla solamente en el voto de las mujeres (sin apelar a la participación). Brumana apoyaba la importancia del rol educador de las mujeres en detrimento del voto. Así puede leerse esa participación en Reconstruir. Bajo el título de "Señora: ¿usted también se lava las manos?", realiza una crítica al estado de inmadurez política en que se encontraban la mayoría de las mujeres argentinas. La autora describe los comentarios de un grupo de mujeres ante la derrota de los candidatos de la Unión Democrática frente al peronismo y señala que una de ellas remite a los acontecimientos de 1945, cuando las feministas sufragistas se unieron en contra de la posible sanción por decreto del voto femenino por parte de Perón:

"Menos mal que rechazamos la concesión del voto femenino con que las autoridades pretendieron favorecernos, porque de haber votado las mujeres, se hubiera dicho que a nosotras se debía el fracaso. Así, estamos libres de tal presunción y que carguen los varones solos con la culpa... Nosotras nos lavamos las manos". 221

Este cuadro de situación hipotético le sirvió a Brumana para señalar la falta de conciencia crítica de las mujeres en su consecución por los derechos políticos. Según el relato que hace Brumana, esas mujeres -evidentemente sufragistas- se aliviaban al no haber obtenido un derecho por el que habían luchado pero, además, no asumían la responsabilidad que les hubiese cabido cualquiera hubiera sido el resultado electoral. En ese sentido, Brumana pone el foco en el problema de que la adquisición del status normativo en el sistema liberal democrático no garantizaba la verdadera conciencia de la ciudadanía. Este es un punto central para el anarquismo. La ley en sí misma no define la ciudadanía sino el compromiso y la participación:

“(...) el voto no es sino una manifestación pública de un estado de conciencia aparejada a un montón de factores entre los que no se desdeña el doméstico, cuya influencia ejercida por la mujer es muy importante $(\ldots)^{\prime 2} \cdot 22$

\footnotetext{
${ }^{221}$ Reconstruir, Año 1, N 1, junio de 1946. Pág. 14.

${ }^{222}$ Ibídem. 
Acto seguido, la autora denunció la condición de atraso e ignorancia en el que las mujeres se habían mantenido desde hacía siglos. Pero la crítica no fue hacia todas las mujeres, sino puntualmente a las de clase media o media alta y su ejercicio de la caridad -el que no era objeto de preocupación de las obreras o de las mujeres pobres:

"En realidad, nuestras mujeres se desentendieron siempre de cuanto problema social aparecía, y creyeron resolverlo todo con el ejercicio de la caridad, en algunos casos, y con un supuesto equilibrio entre el bien y el mal que condensaban en el consabido 'Yo no estoy con ninguno...' Olvidaban que, a menudo, no estar con nadie es criminal...". 223 Inmediatamente después de la sanción de la ley 13.010, la obtención del voto para las mujeres es interpretada por Pavón como el último bastión utilizado por el nazi-peronismo (así lo designa) para terminar de seccionar la libertad de las mujeres que se dirimen en falsas opciones:

"En estos momentos, en que se tienden todos los hilos para cerrar la trama de opresión y asfixia de nuestras libertades públicas (...), sobre la mujer coaccionada entre la sacristía y el voto obligatorio (...)". ${ }^{224}$

Aquí aparece resignificada la idea del voto como cárcel de la expresión libre y consciente. El voto es el que encamina el atraso y la ignorancia de las mujeres en cuestiones de política y participación. No hay una exigencia para que las mujeres se ilustren y eduquen para lograr una participación ciudadana consciente. Por su estado de naturaleza y condiciones culturales y sociales, la mujer-madre se ve fácilmente acorralada por las fuerzas eclesiásticas y totalitarias que dominan su espíritu.

En este punto, el anarquismo señala la falta de madurez de las mujeres en una idea de tono evolutivo que caracterizó también otros discursos, incluso el socialista. Además, el anarquismo descree de la luchas pretéritas de las feministas y coincide con la evaluación de Evita que sugiere que aquéllas habían sido "estériles

\footnotetext{
${ }^{223}$ Ibídem. Aquí también podemos ver una diferencia entre el desentendimiento de la cuestión pública política cuyo ápice es el voto, por una domesticidad "negativa" e ignorante de las mujeres, y la propuesta anarquista de revolucionar la vida doméstica para actuar desde otro paradigma.

${ }^{224}$ Reconstruir, $\mathrm{N}^{\circ} 22$, noviembre de 1947. Pág. 10.
} 
luchas". Sin embargo, mientras Evita y el peronismo se apoyan en el discurso liberal de derechos y conceden a las mujeres un carácter volitivo en ese sistema, el anarquismo impugna no sólo el voto para las mujeres sino al sistema en su conjunto. $^{225}$ Aquí se diferencia el desentendimiento de la cuestión pública política cuyo ápice es el voto, por una domesticidad "negativa" e ignorante de las mujeres, y la propuesta anarquista de revolucionar la vida doméstica para actuar desde otro paradigma.

En este punto, a través de Brumana, se aprecia que la evaluación apunta a la falta de madurez de las mujeres en una idea de tono evolutivo que caracterizó también otros discursos, incluso el socialista. Esta autora, también, descree de la luchas pretéritas de las feministas y coincide con la evaluación de Evita que sugiere que aquéllas habían sido "estériles luchas". Sin embargo, mientras Evita y el peronismo se apoyan en el discurso liberal de derechos y conceden a las mujeres un carácter volitivo en ese sistema, el anarquismo impugna no sólo el voto para las mujeres sino al sistema en su conjunto. No es extraño que Brumana sostuviera esta crítica al feminismo pues no sólo lo consideraba un emergente de carácter burgués, sino que también iba en contra de la idea organizativa de la escritora que rechazaba cualquier organización exclusiva de mujeres.

"Toda la campaña por el voto de la mujer y su desenlace final demuestran que estuvo inspirada en fines demagógicos $y$ de propaganda a favor de quien está en la secretaría de Trabajo y previsión, sin tener cargo oficial alguno. Ya veremos, si todo se desarrolla según los planes previstos, cómo se paga a la "primera dama” por ese su presunto papel de "abanderada de las mujeres argentinas". 226

Estas ideas colocan al anarquismo en coincidencia con el socialismo y el comunismo en cuanto la necesidad de reconocer las luchas previas por el sufragio y

\footnotetext{
${ }^{225}$ Reconstruir, $\mathrm{N}^{\circ} 1$, junio de 1946. Pág. 14

${ }^{226}$ Reconstruir, $\mathrm{N}^{\mathrm{o}} 21$, octubre de 1947.
} 
develar el engaño ejercido por Perón y Eva Perón sobre su rol fundamental en esa lucha y el desconocimiento de los antecedentes. ${ }^{227}$

Así, el anarquismo señala que habría un sufragismo viejo, quizá de bases reformistas o de izquierda (socialista), y uno actual, apoyado por el peronismo y los sectores conservadores. Rescata aquellos proyectos llevados adelante por los grupos y partidos políticos de izquierda y señalan el proyecto del peronismo como un intento de la derecha reaccionaria y de la iglesia para lograr el "voto cautivo" de las mujeres. $^{228}$

'El 'voto femenino', que fue juzgado antes como consigna de las fuerzas politicas avanzadas, es hoy arma que sirve a los demagogos, y que en nada mejora el mecanismo político de las llamadas democracias, que está lejos de garantizar una representación popular verdadera con los clásicos métodos electorales". ${ }^{229}$

La propuesta anarquista consistió, entonces, en reconocer la trayectoria de luchas que conlleva al debate por el voto femenino. De alguna manera, de este modo, se intentaba neutralizar el hecho de que Evita intentara apropiarse de esa lucha que, como dijimos, las sufragistas habían logrado instalar como parte de un sentido de injusticia social. Esta estrategia no fue original de las anarquistas, sino que la totalidad del arco político opositor estableció todo tipo de reconocimientos a

227 Remitimos a los trabajos de Barrancos sobre el sufragio femenino en el socialismo, y a los de Valobra acerca de la Unión de Mujeres de la Argentina (relacionada orgánicamente con el Partido Comunista). Barrancos, Dora (2011). "El Partido Socialista y el sufragio femenino, 1947-1951”, Barry, Carolina (comp.). Sufragio femenino..., op. cit. Valobra, Adriana (2011). "Prácticas y debates sobre los derechos políticos de las mujeres en la UCR y el PCA, 19461955" en Barry, Carolina (comp.). Sufragio femenino..., op. cit.

${ }^{228}$ El voto femenino "(...) figuró en las plataformas partidarias de sectores políticos de todos los matices, y en el congreso de nuestro país se presentaron varios proyectos socialistas sobre el mismo asunto". Reconstruir, $\mathrm{N}^{\circ} 21$, octubre de 1947. Pág. 6. Otro ejemplo de estas ideas aparece en la nota titulada "La emancipación de la mujer", aunque no en la página de la mujer, sino como reflexión general de los temas actuales que trata el periódico: "La igualdad de derechos políticos para la mujer ha sido durante muchos años, objetivo de lucha de los partidos llamados de izquierda y también motivo central para movimientos especificamente feministas, que no dejaron de tener en su hora manifestaciones turbulentas". Reconstruir, $\mathrm{N}^{\circ} 48$, mayo de 1950. Pág. 3.

${ }^{229}$ Reconstruir, № 48, mayo de 1950. Pág. 3 
la acción sufragista precedente, especialmente cuando ellos tenían aportes relevantes que realizar al tema. ${ }^{230}$

Sin embargo, como ya hemos adelantado, el discurso anarquista en estos tiempos no fue unívoco. Otra de las propuestas anarquistas, frente a este sufragismo de tinte conservador, es actuar desde el "feminismo". Si bien es novedad que el anarquismo diferencie al sufragismo del feminismo (como sí lo han hecho en otras corrientes como el radicalismo con Clotilde Sabattini o el socialismo con Alicia Moreau de Justo), lo será aún más el apoyo de otra militante anarquista a la causa feminista. Ana Piacenza es una de las asiduas colaboradoras de las páginas de Reconstruir.

En su primera aparición, propone un análisis acerca de la diferencia entre el sufragismo y el feminismo, y evidencia cómo se perfila ella como anarquista entre estas dos vertientes: "Cada vez que alguna mujer o alguna agrupación femenina agita la propaganda por los derechos políticos vuelve a plantearse el problema del feminismo(...) Sufragismo significa el ejercicio de la función electoral, la práctica del voto". 231

Piacenza menciona los elementos positivos del feminismo frente al reduccionismo que significa el sufragismo, particularmente este sufragismo peronista que lo utiliza de manera instrumental. La idea aquí es remarcar la particularidad del feminismo, diferenciándolo del sufragismo, que como idea y movimiento político, parecería tener una participación más esporádica y pragmática; en contraposición a la profundidad y trascendencia de aquel otro. Aunque no se dio de ese modo en otros ámbitos donde el anarquismo y el feminismo tuvieron lazos tempranos -como expusimos antes-, es una novedad para Argentina.

Para las anarquistas, la propuesta peronista parece más preocupada por el sufragio y las posibilidades de manipularlo en manos de las mujeres que por darles

\footnotetext{
${ }^{230}$ La figura de Clotilde Sabattini y su relación con el feminismo ha sido abordada por Valobra, Adriana (2007). "La tradición femenina en el radicalismo y la lucha de Clotilde Sabattini por el reconocimiento de la equidad política, 1946-1955." Clepsydra, №6. Sobre Alicia Moreau de Justo, Torre, J. C., y Henault, M. (1983). Alicia Moreau de Justo. Centro Editor de America Latina. Deleis, M., Arguindeguy, D. L., y de Titto, R. (2001). Mujeres de la política argentina. Aguilar.

${ }^{231}$ Reconstruir, $\mathrm{N}^{\circ} 2$, junio de 1946. Pág. 11. 
libertad de participación con conciencia y formación, ideales que, en última instancia, no estaban tan alejados del ideario feminista -aún cuando tuviera elementos burgueses-.

Sin embargo, como ya adelantamos, estas consideraciones no se dan sin tensiones. La crítica clásica del anarquismo como doctrina a la idea de democracia liberal como engaño de participación entra en conflicto con el reconocimiento a las ideas de un sufragismo feminista:

"Creo que para nosotras, mujeres socialistas libertarias, el sufragio como base del sistema parlamentario no constituye un problema, ni siquiera una preocupación. Sin duda, vemos aquí una vuelta a sus posturas clásicas en cuanto a la participación política en el sistema democrático". ${ }^{232}$

Pero la necesidad de instalarse en el debate sobre el tema, por la dinámica de la misma controversia, les resulta necesario esbozar sus particulares concepciones sobre el voto de las mujeres en tiempos de una democracia restringida, autoritaria y que se sustenta en la sujeción de sus adeptos. Afirmó al respecto:

"No tenemos interés en contribuir al sostenimiento de regímenes políticos que en nombre de la democracia convierten a los pueblos en manadas de borregos y se sirven de los votos de los ciudadanos para levantar ídolos de barro". ${ }^{233}$

Piacenza es contundente en su postura y salta a la vista la distancia respecto de la de Rouco en los años 30: "Nosotras creemos en el 'feminismo' y no en el 'sufragismo'. 262

No hemos encontrado registro de este tipo antes del período peronista y de esta afirmación de Piacenza avalada por un medio ácrata.

\footnotetext{
${ }^{232}$ Ibídem.

${ }^{233}$ Ibídem,

${ }^{262}$ Ibídem.
} 
“'Feminismo' es, en substancia, la participación de la mujer en la cultura. [...] 'sufragismo', tiene una acepción más reducida y circunstancial, mientras que el segundo, 'feminismo', es más amplio y fundamental". 234

Así, el sufragismo es un obstáculo para las mujeres en tiempos del debate por la ampliación de su ciudadanía política, ya que se nutre fundamentalmente de su genealogía más conservadora y liberal, al servicio del gobiernos fuertes (dictatoriales) y clericales. El nuevo "feminismo" de base anarquista se presenta aquí como medio para encauzar las acciones de estas mujeres, que inevitablemente ya participan de la arena pública. Porque

"Feminismo es aquel amplio movimiento de opinión que abarca no solamente a mujeres, sino también a muchos hombres y cuyo fin es la emancipación total de la mujer. No comprende solamente los derechos políticos, sino y principalmente a los civiles, económicos, sociales y sexuales". ${ }^{235}$

Controvertir con el peronismo acerca del significado del voto femenino, permite a Piacenza manifestar los alcances que el socialismo libertario considera sobre la ampliación de derechos que debería alcanzar.

Este sufragismo peronista, además, se unía en los primeros años con el apoyo de los sectores de sufragistas cercanas al catolicismo como la agrupación que presidía Carmela Horne de Burmeister y que generaban en las libertarias un escozor mayor al avivar el anticlericalismo que cultivaba el movimiento. ${ }^{236}$

El voto de las mujeres no es en sí mismo garantía de la liberación de las mujeres:

\footnotetext{
${ }^{234}$ Ibídem.

235 Ibídem.

${ }^{236}$ Sobre Carmela Horne de Burmeister, ver Barrancos, Dora (2008). Mujeres, entre la casa y la plaza. Sudamericana, Buenos Aires. Sobre anarquismo y anticlericalismo en estos años, ver Bordagaray, M. E. (2012). "Anarquismo y movimiento universitario en Argentina, 1935-1950. Revista $C S, \mathrm{~N}^{\circ}$ 9, Cali.
} 
"Hay países en los cuales las mujeres concurren a las urnas lo mismo que los hombres para elegir a sus gobernantes sin que por eso la sociedad haya experimentado cambio alguno. Esto prueba que el sufragio femenino no resuelve ni atenta ninguno de los grandes problemas en que se debate la humanidad". 237

Resulta recurrente -en los artículos analizados- la denuncia de una relación estrecha entre la Iglesia, la educación eclesiástica, los sacerdotes y las monjas, con el mantenimiento de la sujeción de las mujeres en la ignorancia y el engaño, todo en e un marco de legalidad y de democracia formal:

"Tanto más en nuestros días en que desde el papa hasta los dictadores de todo pelaje y color se muestran dispuestos a conceder el voto al bello sexo (pero sin mostrarse, repetimos, tan magnánimos con todos los demás derechos inherentes al voto)",. ${ }^{238}$

Estas ideas constituían una herencia de las experiencias europeas. Para las anarquistas, como para algunos socialistas e incluso radicales, el caso de España era un antecedente negativo respecto de lo que podía generar la participación de las mujeres. En efecto, consideraban que la República se había perdido en España pues, al votar las mujeres por primera vez, habían orientado su voto hacia las posturas conservadoras. La idea que sustentaba esta interpretación era que las mujeres eran fácilmente influenciables por la Iglesia, que las mantenía en la ignorancia a través de la oración. ${ }^{239}$ Los paralelismos entre el caso español y el peronista apenas se disimulan en Reconstruir: "Esta buena disposición de los sectores conservadores y reaccionarios, debiera ser para nosotras un toque de atención". ${ }^{240}$ El ímpetu sufragista peronista tiene algo tremendamente deleznable y es que

\footnotetext{
${ }^{237}$ Reconstruir, № 2, junio de 1946. Pág. 11.

${ }^{238}$ Ibídem.

${ }^{239}$ Entre una muy amplia bibliografía sobre la situación de las mujeres en España y los debates por el voto femenino en ese país, podemos citar a Capel (1975); Fagoaga (1985) y Nash, (1999). Capel, Rosa María (1975). El sufragio femenino en la Segunda República Española, Granada, Universidad de Granada. Fagoaga, Concha (1985). La voz y el voto de las mujeres. El sufragismo en España, Barcelona, Icaria. Nash, Mary (1999). Rojas. Las mujeres republicanas en la Guerra Civil, Madrid, Taurus.

${ }^{240}$ Reconstruir, № 2, junio de 1946. Pág. 11.
} 
"las fuerzas retrógradas reconocen que van perdiendo terreno entre los hombres y quieren asirse a la tabla salvadora de la ignorancia, la inexperiencia y la domesticidad de las mujeres tan fácilmente manejables desde el confesionario y tan accesibles a los halagos de la vida burguesa". 241

El resultado de las elecciones de 1951 da por sentada la "veracidad" de las advertencias de las y los anarquistas acerca de la "peligrosidad" del voto en mano de las mujeres argentinas en cuanto a su apoyo al régimen totalitario. Interpretan que el debate planteado por el peronismo con respecto al voto para las mujeres, influyó también en los votos del total de la población habilitada para tal ocasión, la masculina. $^{242}$

La interpretación del peronismo como "totalitarismo" permite a los y las anarquistas de Reconstruir elaborar una idea común acerca de cuál es su función frente a tal escenario. Si bien no podemos generalizar, la trayectoria del anarquismo iniciada con el golpe militar de 1930, nos habla de una reorientación y diferenciación en relación con las ideas y acciones "tradicionales del anarquismo" comprendidas entre las primeras décadas del siglo. Acerca de ellas, retomamos lo planteado por Suriano y Barrancos. ${ }^{243}$ Precisamente, es el peronismo el que permite nuevamente la puesta en común y la regeneración del ideario libertario, aunque no sin contradicciones y oposiciones. La declaración que aparece en la primera página del primer número del periódico da cuenta de esta regeneración:

“Queremos que se arraigue en todos la convicción de que el peligro totalitario no ha sido eliminado con la derrota militar de las fuerzas del eje. En nuestro país y en todo el mundo actúan y se manifiestan múltiples formas de absolutismo y tiranía, que bajo diversos pretextos

\footnotetext{
${ }^{241}$ Ibídem.

242 "Uno de los instrumentos del triunfo electoral, fue, para el peronismo, la concesión del voto a la mujer. La propaganda oficial especuló con el otorgamiento de ese derecho, que fue anotado en el haber de la jefa del peronismo femenino". "Voto femenino y reforma electoral", en Reconstruir, N 57, diciembre de 1951, Pág. 4

${ }^{243}$ Suriano, Juan (2001). Anarquistas... op. cit. Barrancos, Dora (1990). Anarquismo..., op. cit.
} 
limitan o anulan la libertad humana y convierten la justicia social en una irrisión (...)”. ${ }^{244}$

En cuanto a cuáles fueron los mecanismos "demagógicos" exitosos llevados a cabo por el aparato peronista, acreditan un rol fundamental al Partido

Peronista Femenino: "Una red del partido femenino se tendió sobre todo el país, favorecida por todos los recursos del poder oficial y extraoficial (...)”. ${ }^{245}$ También adjudican gran parte del mérito al engaño y la manipulación de las mujeres “indefensas" ante semejante parafernalia desatada en pos del objetivo:

"Comisiones recorrieron domicilios instigando, a base de la amenaza velada o abierta, a la afiliación. Maestras y empleadas, obreras y profesionales, amas de casa medrosas, fueron forzadas a la adhesión. $Y$ sin posibilidad de prepararse con tiempo, confundidas, deseosas muchas de cumplir votando en cualquier forma, las mujeres votaron". ${ }^{246}$

A ese voto manipulado, el anarquismo contrapone otro, ínsito en un distinto sistema de representación:

"Sí, las mujeres queremos votar, debemos votar. Pero en los sindicatos, en las comunas. No nos conformamos con votar y dejar a otros la tarea de gobernar. Ya hemos visto que eso es inútil, peligroso y dañino. Queremos los derechos políticos y la responsabilidad politica”. 247

En efecto, la vertiente antiilustrada del anarquismo se potencia en este discurso:

"el ejercicio del sufragio y de la democracia formal, etapa de progreso con relación al absolutismo vigentes antes de la revolución

\footnotetext{
${ }^{244}$ Reconstruir, $\mathrm{N}^{\mathrm{o}} 1$, junio de 1946, Tapa.

${ }^{245}$ Reconstruir, N²3, noviembre de 1947. Pág. 4.

${ }^{246}$ Ibídem.

${ }^{247}$ Reconstruir, № 2, junio de 1946. Pág. 11.
} 
francesa, sólo ha servido para esterilizar las energías populares ante la necesidad de una transformación profunda que llevada a la humanidad -hombres y mujeres por igual- a la verdadera emancipación". 248

Esta cuestión ya no atañe sólo al voto femenino sino a una noción de democracia directa:

"queda por considerar si el sufragio en sí, el sistema consistente en designar gobernantes mediante el ejercicio mecánico de depositar el voto en una urna, constituye un instrumento de liberación o la forma más deseable de organizar la vida de relación", 249

Precisamente, las propuestas socialistas libertarias que estamos analizando proponen la participación directa de los hombres y las mujeres en todos los ámbitos en que se desarrollan.

"Las fábricas deben ser dirigidas y administradas por sus obreros, técnicos y profesionales (...); los centros de enseñanza en sus diversos grados, las asociaciones de actividad artística y de expansión cultural, serán orientadas autónomamente por sus profesores, maestros, egresados y alumnos". ${ }^{250}$

\section{El interesamiento. El agenciamiento político de las mujeres en la organización libertaria.}

El "interesamiento" es el conjunto de acciones mediante las cuales una entidad (aquí los anarquistas que adhieren al socialismo libertario) intenta imponer y estabilizar la identidad de los otros actores que define a través de su

\footnotetext{
${ }^{248}$ Reconstruir, No 48 , mayo de 1950. Pág. 3.

${ }^{249}$ Ibídem.

250 "Declaración de principios", USL de Capital Federal, 1946. s/n.
} 
problematización. Y para implementar estas acciones se emplean diferentes mecanismos. Para ello, resulta necesario identificar los repertorios organizacionales con los que el colectivo libertario intenta "interesar" a estas mujeres. El interesamiento, además de una retórica -expuesta en los parágrafos anterioresrequiere de estructuras organizativas que permitan vehiculizar la palabra -a través de la prensa- y que efectivice prácticas específicas en el ámbito público. Siguiendo a Callon, "estar interesado significa estar en medio (interesse), estar interpuesto". ${ }^{251}$ Es en este sentido en el que hay que entender el "interesamiento": interesar a otros actores es construir mecanismos que puedan colocarse entre ellos y todas las demás entidades que quieran definir sus identidades de otra manera. Si lo traducimos, las propiedades e identidad de las mujeres se consolidan y/o redefinen durante el proceso de "interesamiento". Esta identidad es el "resultado" de la asociación que lo liga a las anarquistas. Este vínculo, al mismo tiempo, desligaría a las mujeres del peronismo-totalitarismo que intenta darle otra definición. Callon ha llamado a esta relación elemental que empieza a dar forma y consolidar el vínculo social, como "el triángulo de interesamiento". El abanico de estrategias y mecanismos que pueden adoptarse para lograr estas interrupciones es ilimitado. Puede ser la fuerza; puede ser la seducción o la simple solicitud. Resulta difícil que la entidad de "las mujeres" coincida perfectamente con la problematización propuesta por los anarquistas ya que, en general, la identidad de los actores se modifica a lo largo del proceso de interesamiento. Para avanzar en el análisis, resulta indispensable plantear algunas preguntas: ¿es posible que las mujeres adhieran a la lucha a la que están siendo convocadas por los libertarios?, ¿es el peronismo un representante local del fascismo?, ¿es el voto femenino una trampa de participación en el marco de un estado fascista-corporativista?

Las Uniones Socialistas Libertarias (USL), según el manifiesto fundacional de la USL de Capital Federal, surgen en Méjico alrededor del año 1932 como fenómeno organizativo propuesto por el anarquismo mexicano pero con la intención de representar un frente de resistencia cultural frente al fenómeno fascista en clara expansión en el continente europeo. ${ }^{252}$ Allí tuvieron la adhesión de renombrados teórico marxistas, y de miembros del Partido Comunista mejicano. En palabras de

\footnotetext{
${ }^{251}$ Callon, Michelle (1986). "Some elements ...", op. cit.

${ }^{252}$ La referencia al origen Mexicano de las USL, aparece en "Declaración de principios", USL (1946), op. Cit.
} 
la organización local de las USL, éste fue el modelo organizativo a seguir, pensando en la realidad argentina del año 1946 y reconociendo la poca adherencia de las masas populares al anarquismo (menos aún a la organización libertaria). Entre marzo y junio de 1946, se crean la Unión Socialista Libertaria de Rosario, la USL de La Plata, USL de Capital Federal, la USL de Santa Fe, la USL de Ramos Mejía, San fernando, Tigre y la USL de San Juán. A pesar de que se presenten como agrupaciones independientes y sin ninguna relación orgánica con la FACA, hemos comprobado que los miembros fundadores de las USL son históricos militantes faquistas: Ana Piacenza y José Grunfeld fundan la de Rosario, Herminia Brumana en la USL de Capital Federal, Jacobo Maguid, David Kraiselburd y Lunnazzi en la de La Plata. En las actas declarativas éstos vierten opiniones compartidas sobre la propuesta constructiva que representan. Incluso la declaración de principios de la USL de La Plata será reproducción exacta del manifiesto constitutivo de la de Capital Federal. Internamente, cada una de estas uniones, se organizaba en comisiones de trabajo. ${ }^{253}$ El público era convocado a participar en actividades culturales como charlas $\mathrm{u}$ homenajes a artistas universales (como por ejemplo León Felipe en la USL de Capital Federal), salidas de "excursionistas" a lugares como San Fernando, Tigre o Punta Lara o a formar parte en la creación de experimentos teatrales y de educación alternativa en la USL. ${ }^{254} \mathrm{Al}$ mismo tiempo, editaron numerosas obras políticas, poéticas y ensayísticas, que sostenían económicamente a la organización. ${ }^{255}$

No es posible hacer generalizaciones sobre la naturaleza y la actuación política concreta de estas agrupaciones. Si bien, por un lado, todas tienen el mismo origen porque parten de las acciones de muchos de los miembros de la FACA, las diferencias internas son muchas. Estas divergencias llevan, por ejemplo, a que la FACA se desvincule en el año 1949 de la USL de Capital Federal, pero reconozca positivamente lo actuado por la USL de Rosario. La participación de las mujeres en estas organizaciones se limitó a aquellas que por su formación y trayectoria en el

\footnotetext{
${ }^{253}$ Unión Socialista Libertaria, Folleto, Capital Federal, 1948.

${ }^{254}$ León Felipe (Felipe Camino Galicia de la Rosa) fue un poeta e intelectual español, militante republicano durante la guerra civil española. Posteriormente se exilió en México, donde muere en 1968.

${ }^{255}$ Graciano, Osvaldo (2012) "La escritura de la realidad. Un análisis de la tarea editorial y del trabajo intelectual del Anarquismo argentino entre los años '30 y el Peronismo", en Revista Izquierdas, $\mathrm{N}^{\mathrm{o}} 12$, Chile. www.izquierdas.cl.
} 
campo anarquista, estaban ligadas a los sectores intelectuales y organizativos. Estos son los casos de Herminia Brumana y de Lola Quiroga, quienes sostuvieron la USL de Capital Federal, junto a hombres como Diego Abad de Santillán, Manuel Martín Fernández. ${ }^{256}$ Así, en los múltiples actos que la organización realiza entre 1946 y 1951, las encontramos como oradoras y organizadoras de actividades. ${ }^{257}$ No es posible establecer, en base a los documentos analizados, si cada una de estas organizaciones contaba con una "comisión femenina", aunque si podemos observar que la USL de Capital Federal contemplaba una "comisión juvenil", "comisión biblioteca", una comisión que evaluaba las políticas de acción con respecto al movimiento obrero, entre otras. ${ }^{258}$ Podemos inferir que la especificidad de la cuestión femenina no fue un lema que Herminia Brumana sostuviera dentro de esta organización. Sus intervenciones públicas se refieren a temas como el rol de la cultura en la sociedad argentina, la educación libre o los fundamentos del socialismo libertario. ${ }^{259}$ De este modo, así como Brumana propone desde Reconstruir la necesidad de comprender las dificultades de las mujeres para lograr el cambio social y sostiene un espacio en ese periódico escrito por mujeres y dirigido a las mujeres, mientras que en el nivel organizativo se opone a esa especificidad.

Precisamente a esta estrategia es a la que apuesta Ana Piacenza con la creación de la Unión de Mujeres Socialistas libertarias de Rosario (UMSLR) en 1946. Agrupación exclusivamente formadas por mujeres, la UMSL posee una agenda particularmente centrada en los reclamos históricos de las mismas y, a su vez, reformulando los históricos postulados de las libertarias. Resumidamente, en el manifiesto constitutivo de la UMSLR, se plantean los siguientes objetivos y exigencias al gobierno peronista:

\section{“(...) El pleno ejercicio de los derechos individuales, la estabilización e integridad de la familia en base a una reforma total del sistema educacional primario, secundario y superior, la libre iniciativa en los}

\footnotetext{
${ }^{256}$ Sobre Lola Quiroga y Manuel Martín Fernández, odontóloga y médico anarquistas, ver Ledesma Prietto, Nadia (2012). “Apuntes...”, op. cit.

257 "Memoria y Balance” (1948). USL de Capital Federal. Reconstruir $\mathrm{N}^{\mathrm{a}} 1, \mathrm{~N}^{\mathrm{o}} 2, \mathrm{~N}^{\mathrm{o}} 4$.

${ }^{258}$ Ibídem.

${ }^{259}$ Ibídem.
} 
hombres y los pueblos propiciando el federalismo interior y entre naciones como medio para asegurar la paz y la fraternidad entre los hombres del mundo, orientándose hacia la ciudadanía universal, la igualdad de todos los derechos para hombres y mujeres, protección de la maternidad, maternidad consciente, protección a las mujeres que trabajan, seguro de maternidad, abolición del trabajo para los niño (...)". ${ }^{260}$

La educación de la mujer, maternidad consciente y voluntaria, una ciudadanía radicalizada en el sentido libertario de participación y decisión, derechos diferenciados para mujeres trabajadoras: podemos observar una apelación diferente con respecto a la que hemos observado al analizar las incumbencias de las anarquistas con respecto al voto femenino. En este manifiesto, la UMSL apela al Estado para obtener derechos.

Otra organización de mujeres aparece en estos años actuando de la mano del movimiento obrero de tendencia ácrata en Mar del Plata es la Agrupación Femenina de Capacitación y Lucha por los Derechos de la Mujer. Si bien no contamos con información sobre las particularidades organizativas ni de sus miembros, en uno de los manifiestos que dan a conocer con motivo del triunfo de la huelga llevada a cabo por los panaderos de aquella ciudad, plantean que la lucha por las mejoras en la vida de los obreros debe desarrollarse de la mano de los hombres.

"Como mujeres, especialmente por pertenecer a una agrupación en parte integrada por obreras, que ha nacido en una casa de trabajadores y al calor de las justas aspiraciones proletarias, no podemos permanecer indiferentes a las inquietudes las luchas que sostenga la clase obrera en cualquier lugar del país. (...) hay que prepararse para librar nuevas luchas que sean decisivas para el bienestar de la clase obrera y en las cuales las mujeres cumpliremos con nuestro deber a la par de los hombres". 261

\footnotetext{
${ }^{260}$ Reconstruir, $\mathrm{N}^{\circ} 2$, julio de 1946. Pág. 8.

${ }^{261}$ Reconstruir, $\mathrm{N}^{\circ} 7$, septiembre de 1946. Pág. 7 
De esta manera, es posible dar cuenta de una agrupación de mujeres que actúa en el movimiento obrero. ${ }^{262}$ Sin embargo, la especificidad de la cuestión femenina no aparece como un componente fundante para las mujeres de esta organización sino más bien como la base a partir de la cual se nuclean mujeres, las que posteriormente "contribuirían" a la lucha de los obreros en general. ${ }^{292}$ Del mismo modo, Iris Pavón, refuerza en estos años su oposición a las formaciones puramente femeninas. $^{293}$

\section{Consideraciones finales}

En este capítulo nos propusimos una crítica a la producción historiográfica que trató las agencias femeninas y las cuestiones de género en el anarquismo argentino de la primera mitad del Siglo XX en la Argentina. La focalización en esta temática no es azarosa. En la bibliografía de las últimas tres décadas, se han abordado las relaciones entre anarquismo y feminismo. Nuestra pregunta apuntó a poner en tensión estas categorías, problematizar y matizar lo que se ha presentado como parte del "el sentido común historiográfico". ${ }^{263}$ En relación a este último, nos interesa señalar que el análisis historiográfico de estas dos cuestiones junto a su incorporación al ámbito académico, ha llevado a anacronías y simplificaciones al momento de trazar los derroteros del anarquismo y el feminismo.

Como reflexión final, creemos que los análisis feministas en la reconstrucción de la historia de las mujeres y el anarquismo contiene un problema de fondo: la rigidez de las categorías y la volatilidad de sus características.

Asimismo, en algunos casos ha faltado el afán de "historizar" el contexto de producción de estas obras que se enmarcan en el movimiento feminista y el ámbito académico. En los análisis, a pesar de que se reconoce la heterogeneidad presente en los movimientos de mujeres, en la práctica se valora la homogeneidad y

\footnotetext{
${ }^{262}$ Este tema será retomado en el siguiente capítulo.

${ }^{292}$ Reconstruir, No 7 , septiembre de 1946. Pág. $7^{293}$

Reconstruir, $\mathrm{N}^{\circ} 3$, julio de 1947.

${ }^{263}$ Retomamos la noción de Nieto, Agustín. “Anarquistas y obreras del pescado: Una experiencia de organización sindical en los años '40”, en Historia Regional, Sección Historia, ISP Nº 3, Año XXI, $\mathrm{N}^{\mathrm{o}} 26,2008$, pp. 89-117.
} 
coincidencia con un tipo de lucha y un modelo de reivindicación. Ello implica privilegiar determinadas características del movimiento y subsumir otras, dependiendo del prisma con el cual se lo observa. En ese sentido, vale la pena mencionar -junto con Lola Luna- que no ha sido sólo desde una perspectiva feminista la manera en que las mujeres han expresado sus demandas, politizando lo privado y ampliado el campo de la política. ${ }^{264}$ Partiendo de este problema, nuestra propuesta conjuga una mirada crítica con respecto a las acciones llevadas adelante por las mujeres anarquistas hacia las mujeres, por el anarquismo como doctrina con respecto a la mujer y las especificidades que plantean en las controversias sostenidas con el peronismo. Creemos que la coyuntura política impulsa apreciaciones particularísimas, novedosas y escasamente visibles frente a las miradas que saturan las posibilidades de acción de las mujeres en la obtención del voto femenino por parte de Eva Perón.

Hemos encontrado lecturas del "feminismo" (entre comillas ya que respetamos la autorreferencialidad de nuestras actuantes) menos beligerantes en el contexto del peronismo también relacionadas con el movimiento libertario. ${ }^{265}$ Reconocemos de todos modos la importancia del aporte feminista en la reformulación del campo académico, particularmente en la posibilidad que nos brinda de vislumbrar nuevos sujetos históricos (fundamentalmente a las mujeres) y de ampliar el espectro de las "categorías analíticas" con las que abordamos el estudio del anarquismo, del pasado y de las sociedades en general.

En nuestro estudio, las controversias se desplegaron sobre dos ejes. El primer eje es sobre las políticas de maternidad. En segundo lugar, la noción de ciudadanía política que propone el peronismo, se ven obligadas a llevar la discusión a categorías conceptuales que no son propias del anarquismo. De allí que tuviera que discutir términos como el del sufragio. Para ello, diferencian entre el sufragismo feminista y el peronista. Establecen, rompiendo sus posturas históricas sobre el particular, un reconocimiento al primero, en desmedro del segundo. Ana Piacenza y Heminia Brumana intervendrán permanentemente en este sentido. A partir de estos núcleos discursivos y de acción política, es posible visualizar de qué

\footnotetext{
${ }^{264}$ Luna, Lola (1994) “Estado y participación política de mujeres en América Latina...” op. cit, pág. 38

${ }^{265}$ Bordagaray, María Eugenia (2011). "Las anarquistas argentinas y el voto femenino (19461952)", en Barry, Carolina (comp.) Sufragio femenino, op. Cit.
} 
manera las mujeres anarquistas determinaron un conjunto de actores y definieron sus identidades de tal modo que se situaron a sí mismos en un punto de paso obligado de la red de relaciones que estaban construyendo.

Creemos que es en esta construcción dinámica en que las anarquistas logran crear una serie de "regularidades" en su acción y en sus discursos que nos pueden llevar a pensar en un colectivo de ideas pasible de ser identificado como "anarquista". ${ }^{266}$ Sin embargo, es posible hallar -en esta construcción dinámica de sus repertorios- acuerdos y oposiciones dentro del mismo movimiento. Las diferencias aparecen fundamentalmente en torno a la idea de "feminismo" como ideal a seguir o como ideal desechable propio del liberalismo burgués. Es precisamente la mirada benévola hacia algunas cuestiones feministas la novedad representada por la propuesta de Reconstruir, aunque no podemos generalizarla hacia todos los miembros del grupo. Hemos visto cómo, a través de un proceso contrahegemónico, Reconstruir desarrolla un repertorio discursivo que intenta

“(...) poner al desnudo la parcialidad de la ideología dominante mediante la que se construían las justificaciones del poder". ${ }^{267}$ Pero como indicáramos anteriormente, las tensiones discursivas que plasman las ideológicas son inherentes a la práctica política. Así vemos algunas similitudes entre las nociones maternalistas en el discurso peronista y en las propuestas anarquistas. Al mismo tiempo, resulta a toda vista necesario poner en evidencia las relaciones entre el análisis "feminista" de Piacenza y el feminismo de La Voz de la Mujer analizado por Molyneux y las similitudes entre las intervenciones de Pavón, Goyena y

Brumana con el "antifeminismo maternalista" de Nuestra Tribuna analizado por Barrancos. $^{268}$ La adscripción "feminista" de esta anarquista es realmente una novedad si tenemos en cuenta la crítica tradicional al feminismo burgués que caracterizó a las anarquistas en Argentina, a diferencia de lo que sucedía con los

\footnotetext{
${ }^{266}$ Steinberg, Rudolph (1999), "El rugir de la multitud...", op. cit.

${ }^{267}$ Ibid, Pág. 229.

${ }^{268}$ Molyneux, Maxine (1997). “Ni Dios ni patrón ni marido...”, op. cit.; Barrancos, Dora (1990), Anarquismo..., op. cit.
} 
vínculos estrechos que éstas habían desarrollado en España, en particular, durante la República y la Guerra Civil española, según Mercedes Yusta. ${ }^{269}$

Las tensiones en los discursos y las apuestas de las anarquistas pueden relacionarse con el hecho de que el anarquismo intenta entrar en la arena política en que se disputa la hegemonía de los sentidos, sobre todo para lograr el acercamiento de las mujeres al anarquismo y, de forma paralela, para hacerlas desistir de sus decisiones pro peronistas influidas por el crecimiento de la propaganda oficial en pos del voto femenino. Sus alianzas tácitas con los sectores de la oposición lo llevarían a diferenciar el sufragismo y el feminismo a los que antes se había opuesto como si se hubiese tratado de conceptos unificados y que, ahora, el sufragismo no feminista del peronismo venía a complejizar.

Para el anarquismo, el principal problema que parece presentar el voto en mano de las mujeres es su manipulación por parte del Estado peronista, con fines puramente electoralistas y demagógicos. Para los anarquistas, el problema es el sistema democrático "real", en el que cualquier manifestación de opresión puede darse si hay un trasfondo legal que lo permita. En este sentido, resulta interesante el abordaje que realiza Suriano en relación a las nociones anarquistas sobre las trampas del sistema política formal las posibilidades de la acción política directa en tiempos en que se discutía la ampliación de la ciudadanía que culminan con la sanción de la Ley Sáenz Peña en 1912. ${ }^{270}$ Podemos decir, de acuerdo a los documentos que hemos analizado, que muchos de estos postulados se sostienen en los años en que se debate la ampliación de la ciudadanía hacia las mujeres.

Finalmente, la presencia de las mujeres nos permite plantear cuál es el sujeto del anarquismo, el universal: ¿Está generizado?, ¿invisibiliza a la mujer en el universal masculino típico de la modernidad?

Como vimos en el capítulo precedente, las trayectorias de las mujeres que comienzan su militancia en estos años (podemos denominarlos de la lucha antifascista) en el anarquismo tiene profunda relación con lo actuado en los años del

\footnotetext{
${ }^{269}$ Yusta, Mercedes (2005). "Las mujeres en la resistencia antifranquista, un estado de la cuestión”, en Arenal. Revista de Historia de las Mujeres, $\mathrm{N}^{\circ} 12$.

${ }^{270}$ Suriano, Juan (1997). "Las prácticas políticas del Anarquismo argentino", en Revista de Indias, $\mathrm{N}^{\circ} 57,421-450$. 
peronismo. Para ello, siguiendo la apuesta metodológica por pensar las relaciones en clave de controversias, establecimos diferentes escenarios en los que la actuación de las libertarias se dirime en tiempos del peronismo en el poder. Así, identificamos a dos oponentes o sujetos con los que estas controversias se establecen: en primer lugar, el Estado peronista; en segundo lugar, el movimiento sufragista ligado al peronismo. Así con cada uno de estos sujetos las libertarias establecieron controversias diferenciadas en torno a diferentes temas caros a las apuestas anarquistas en estos años: con el Estado peronista debatirá acerca de la naturaleza de la partición política que éste propone a las mujeres (dirigida, subsidiaria, totalitaria y misógina). El anarquismo intentó una propuesta distinta sobre la movilización femenina. Para contraponerse a la movilización peronista, el anarquismo interpela a las mujeres considerando la maternidad en clave revolucionaria, en oposición a las ideas de "maternidad" más conservadoras, incluidas la de la "madre peronista" que se esboza desde el gobierno. Iris Pavón es claramente quien representa esta postura.

\section{Capítulo 4}

\section{LAS DISPUTAS POR LOS TRABAJADORES}

El objetivo principal de este capítulo es analizar la apuesta pública de los libertarios, nucleados fundamentalmente en la $F A C A$. A través de los documentos institucionales y la prensa periódica como Acción Libertaria y las consideraciones expresadas por el grupo editor Reconstruir, nos proponemos analizar concretamente- el modo en que el anarquismo se propuso apelar/disputar con el peronismo a los "obreros-trabajadores" como herramientas para la resistencia a la dominación de lo que consideraron un "gobierno totalitario". Intentaremos, asimismo, vislumbrar en esa interpelación, las características del género que constituyen a ese sujeto obrero. 
Para esa apuesta política, el anarquismo partió de una crítica generalizada a las estrategias sindicales y de movilización de los trabajadores llevadas a cabo por el peronismo, así como del modelo sindical propuesto por éste, y retomó estrategias como la huelga general y la solidaridad con las causas de trabajadores no alineados con el Estado como estrategia de lucha.

La cuestión obrera ocupó la mayor parte del espacio del periódico orgánico de la FACA, mientras que sólo una página de Reconstruir -prensa que tenía un objetivo más enfocado en la dimensión cultural y la interpelación a sujetos más amplios que los tradicionalmente apelados por el movimiento libertario- fue dedicada a las noticias del mundo obrero a partir de sus números iniciales.

La aparición del peronismo en la escena política y sindical representó para el anarquismo la posibilidad y el desafío de elaborar discursos y estrategias políticas específicas sobre la cuestión obrera y esto adquirirá formas concretas en la redacción de su prensa. Como señala James: "La era peronista borró en gran medida las anteriores lealtades políticas que existían en las filas obreras e implantó otras nuevas". ${ }^{271}$ A partir de este momento, hablar del movimiento obrero significaría hablar también del peronismo.

Como ya hemos señalado, si bien la historia del anarquismo y su influencia en el movimiento obrero es referenciada en la mayoría de los trabajos que abordan el tema, no es posible encontrar en ellos una línea argumentativa sólida que coloque al anarquismo actuando dentro del movimiento obrero para los años 30, salvo de manera excepcional. López Trujillo identifica agrupaciones, estrategias y alianzas impulsadas por la FACA, como las que pueden encontrarse, por ejemplo, en la Comisión Obrera de Relaciones Sindicales (CORS). ${ }^{272}$ Iñigo Carrera, por su parte, individualiza la figura de Horacio Badaracco y de la Alianza Obrera Spartacus, agrupación anarco-comunista, en cuanto al rol preponderante que tuvieron en la huelga general de la construcción de 1936:

${ }^{271}$ James, Daniel (1990). Resistencia e integración. Buenos Aires, Sudamericana. Pág. 25.

${ }^{272}$ López Trujillo, Fernando (2005). Vidas en rojo y negro..., op. cit. Sobre la participación faquista en el mundo obrero y sindical entre 1935 y 1943 ha sido abordada en el Capítulo 1 de este trabajo. 
“Los miembros de la Alianza Obrera Spartacus tuvieron una importante participación en la organización de la huelga general de 1936 y en las acciones de masas en las calles. Y, a diferencia de otras organizaciones politicas vinculadas al movimiento obrero, asumieron la autoría de esas acciones, lo mismo que el Comité

Regional de Relaciones Anarquistas (C.R.R.A). (...) Horacio Badaraco, orientador de la Alianza Obrera Spartacus, redactó los boletines de huelga y a él se atribuye el plan del Comité de Solidaridad con los Obreros de la Construcción para desarrollar las acciones en las calles de Buenos Aires, organizando mitines, asambleas sucesivas avanzando desde la periferia al centro de la ciudad". 273

La mencionada huelga general, del 7 y 8 de enero de 1936, es considerada la más importante de la década, fundamentalmente por la repercusión que tuvo a nivel nacional. Habiendo comenzado como muestra de solidaridad con la huelga de la construcción en octubre de 1935, la heterogeneidad del apoyo que logró se visibilizó en las manifestaciones públicas tanto de obreros fabriles como de mujeres, trabajadores de la construcción y los sectores populares en general. Débora D'antonio aborda precisamente las huelgas de 1936 en perpectiva de género. ${ }^{274}$

Según Iñigo Carrera, en este conflicto se manifiestan las diferentes tendencias y propuestas sostenidas por las diferentes facciones dentro del heterogéneo grupo de huelguistas:

"En esta huelga, lo mismo que en la huelga de los obreros de la construcción, se hizo manifiesta la confrontación entre las distintas alternativas (insertarse en el sistema institucional político y jurídico en las mejores condiciones posibles sin pretender su transformación

\footnotetext{
${ }^{273}$ Iñigo Carrera, Nicolás (s/d). "La Alianza Obrera Spartacus", en Cuadernos de Trabajo, PIMSA, No 26. Pág. 2

${ }^{274}$ D' antonio, Débora (2000) "Representaciones de género en la huelga de la construcción, Buenos Aires, 1935-36", en Fernanda Gil Lozano (et.al.)(comps.). Historia de las Mujeres en la Argentina, Siglo XX. Buenos Aires, Taurus.
} 
de raiz, realizar una lucha <mejorativista $>$ sin perder de vista la transformación radical del sistema social". ${ }^{275}$

El mismo autor recupera las agencias de la FORA en relación con las huelgas que se suceden ininterrumpidamente entre 1932 y 1936. Del mismo modo, los enfrentamientos entre los grupos ligados a la FORA y aquellos denominados antorchistas (por el hecho de nuclearse en torno al periódico y grupo editor de La Antorcha) aún se mantienen. Precisamente, los fundadores de la Alianza Obrera Spartacus provienen de este segundo sector. Recordamos aquí que muchos de los militantes que fundan la FACA también pertenecen a esta tendencia dentro de las vertientes en que el anarquismo se dirime en la década del 20. Si bien Badaraco y muchos de los spartaquistas participan de los congresos previos a la formación de la FACA, definitivamente no participarán en esta última.

Para 1935, las dos organizaciones ya tienen entidad e ideología propia. Según las fuentes referidas por Iñigo Carrera, la principal diferenciación entre los foristas, faquistas y spartaquistas es la opción de estos últimos por la organización de sindicatos y uniones obreras por industria, en las cuales no rechazaban incluso alianzas con las tendencias comunistas o socialistas. Por otro lado, se oponían a pensar a la nueva sociedad "anarco-comunista" como resultado de una alianza de todos los oprimidos. Su apuesta se centraba en la organización obrera y en el obrero como sujeto de la revolución. La diferencia con la FORA tiene que ver con las formas de organización sindical, puesto que los spartaquistas apelaban a la unidad de los gremios dentro de cada industria, mientras que la FORA seguía pugnando por la organización por oficio. ${ }^{276}$ El proceso y las apuestas de la FACA con respecto a la cuestión obrera y sindical han sido descriptos en el capítulo 1 . Sin embargo, recuperamos aquí los ejemplos de participación sindical articulados por el faquismo en los años ' 30 puesto que observamos una continuidad de las estrategias

\footnotetext{
${ }^{275}$ Iñigo Carrera, Nicolás (s/d). "La Alianza Obrera Spartacus”..., op. cit. Pág. 3. El mismo autor ha trabajado en profundidad la huelga general de 1936. Iñigo Carrera, Nicolás (2000). La estrategia de la clase obrera. 1936. Buenos Aires, La Rosa Blindada / Pimsa.

${ }^{276}$ Iñigo Carrera, Nicolás (s/d). La Alianza Obrera Spartacus..., op. cit. Otro trabajo reciente aborda las acciones sindicales de base de la FACA y la Alianza Obrera Spartacus. Ceruso, Diego (2011). "El trabajo sindical de base del anarquismo argentino: la FACA y la Alianza Obrera Spartacus", en A Contra corriente. Una revista de historia social y literatura de América Latina. Vol 8, $\mathrm{N}^{\circ} 3$. www.ncsu.edu/project/acontracorriente.
} 
organizativas y de acción que fueron formuladas por el mismo colectivo frente al peronismo.

En general, las estrategias de aquellos sectores obreros organizados que se opusieron a las políticas que el Estado peronista desplegó en relación con los trabajadores, también han sido abordadas sin mencionar la participación libertaria, en tanto sujeto político opositor de peso en las filas obreras y organizaciones políticas antiperonistas. $^{277}$

Algunos trabajos recientes que se centran en conflictos obreros puntuales visibilizan la participación de militantes anarquistas en algunos sindicatos o uniones obreras en la década del 40. Es el caso de los trabajadores gráficos que sostienen una importante huelga en el año 1949. Luis Dannusi, organizador y dirigente faquista, fue también una figura fundamental en la oposición a las facciones del gremio gráfico que apoyaba al gobierno de Perón y su política sindical. Mimbro fundador de la Federación Argentina de los Trabajadores de la Imprenta (FATI), la mayoría de los trabajos que aborda el tema destaca su rol en el sostenimiento de la huelga gráfica del año $1949 .{ }^{278279}$ Al año siguiente de la mencionada huelga, se producirá otra huelga para la que también se ha rastreado la influencia anarquista, como lo es la sostenida por los obreros marítimos. Según Contreras, al panorama de la huelga general convocada por la Confederación General de Gremios Marítimos y Afines (CGGMA, organismo de orientación sindicalista en donde se agrupan la mayoría de los gremios marítimos), se le sumó la solidaridad de otros dos gremios del puerto dirigidos por el anarquismo: la Federación Obrera de Constructores

277 Doyon, Louise (2006). Perón y los trabajadores. Los orígenes del sindicalismo peronista, 19431955. Buenos Aires, Siglo XXI. Horowitz, Joel (2004). Los sindicatos, el estado y el surgimiento de Perón, 1930/1946. Editorial de la Universidad Nacional de Tres de Febrero. Baily, Samuel (1985). Movimiento obrero, nacionalismo y política en Argentina. Buenos Aires, Hyspamerica. Del Campo, Hugo (1983). Sindicalismo y peronismo. Los comienzos de un vínculo perdurable. Buenos Aires, CLACSO. Murmis, Miguel y Portantiero, Juan Carlos (1972). Estudios sobre los orígenes del peronismo. Buenos Aires, Siglo XXI.

${ }^{278}$ Little, Walter (1979). "La organización obrera peronista y el Estado peronista, 1943-1955" en Desarrollo Económico, Vol.19, N75, Buenos Aires, Págs. 331 - 375. Ghigliani, Pablo (1998). "La Federación Gráfica Bonaerense Y la irrupción del peronismo”, en Cuadernos del CISH, Vol. 3, nº 279 . Contreras, Nicolás (2007). "De todos modos las rotativas pararon. La huelga de obreros gráficos de 1949”. Ponencia presentada en $I^{\circ}$ Jornadas de Jóvenes Investigadores. Universidad Nacional de Mar del Plata, 31 de mayo y 1 de junio. Disponible en http://historiapolitica.com/datos/biblioteca/contreras1.pdf. 
Navales (FOCN), cuyo apoyo a la huelga contaba con la anuencia de sus 6000 afiliados, y la Sociedad de Resistencia de Obreros del Puerto. ${ }^{280}$

Agustín Nieto, por su parte, describe el proceso por el cual se constituye el Sindicato Obrero de la Industria del Pescado (SOIP) en Mar del Plata, que se vincula con las Juventudes Libertarias de dicha ciudad y que se enmarca en un desarrollo más general, en el que la FACA propone participar sindicalmente a través de la creación de un sindicato de industria. El autor explica el apoyo de las Juventudes Libertarias y la Unión Obrera Local de la ciudad, respaldando las actuaciones de las obreras del pescado nucleadas en aquel sindicato. Destacamos el dato que nos brinda Nieto acerca de que el $90 \%$ de la fuerza empleada en la industria pesquera eran mujeres. El autor refiere también que la huelga general fue la principal estrategia del movimiento obrero no alineado con el peronismo. Por medio de la huelga general, estos sindicatos lograron mejoras en las condiciones laborales. $^{281}$ Focalizando en las mujeres obreras, Irene Molinari visibiliza a las mujeres obreras de la industria de la conserva marplatense, describiendo cuáles fueron las condiciones laborales con anterioridad a 1940, y los triunfos obtenidos tras la creación del sindicato y las huelgas:

"Las condiciones de trabajo variaron a lo largo del período. Hasta los primeros años cuarenta, las conserveras trabajaban mojadas y bajo el agua, debido a que el pescado era limpiado con abundante líquido. Además, las obreras trabajaban paradas más de 12 horas. Estas condiciones comenzaron a modificarse a partir del año 1942 cuando se les reconoció su sindicato. Los cambios consistieron en colocar tablones para los pies, bancos en el lugar donde envasaban, los cuarto de hora para descansar o comer, aunque la extensión de la jornada no se modificó. "282

\footnotetext{
${ }^{280}$ Contreras, Nicolás (2008). “Clase obrera y peronismo. La "gran" huelga marítima de 1950", Ponencia presentada en XXI Jornadas de Historia Económica. Asociación Argentina de Historia Económica. Universidad Nacional de Tres de Febrero. Caseros (Buenos Aires), 23 al 26 de septiembre.

${ }^{281}$ Nieto, Agustín (2008) "Anarquistas y obreras del pescado: Una experiencia de organización sindical en los años 40", en Historia Regional, Sección Historia, ISP N ${ }^{\circ}$ 3, año XXI, $\mathrm{N}^{\circ} 26$.

${ }^{282}$ Molinari, Irene (2008). "Obreras, operarias y empleadas. El trabajo de las mujeres en Mar del Plata, entre los años 1940 y 1960.”, en Trabajos y Comunicaciones, № 34. Pág. 158.
} 
Como ya hemos señalado en la Introducción de la presente investigación, las pesquisas que apuntan a recuperar voces, estrategias y acciones libertarias a partir de 1940, son muy escasas. Retomamos los relatos historiográficos que las abordan, en el sentido de que nos brindan la posibilidad de visibilizar las agencias anarquistas en los años que exceden a las cronologías "clásicas" para el anarquismo en Argentina. A partir de estas lecturas, percibimos que la huelga general fue una estrategia que el movimiento libertario, por medio de sus organizaciones obreras, intentó expandir por todo el territorio de la Argentina en donde tuvieran presencia no sólo en la dirección sindical sino también por medio de la solidaridad con aquellos que aliados de las huestes libertarias, optaran por la huelga como forma de lucha contra el Estado o los grupos patronales. Sin embargo, la estrategia de la huelga general, o la profundización de los conflictos gremiales allí donde el anarquismo tuviera cierta participación o presencia, antecede a este período para la FACA. ${ }^{283}$ Incluso, en sus reformulaciones doctrinarias y los debates profundos sobre las acciones a sostener como organización específica anarquista a partir de 1935, la huelga general continúa siendo el objetivo principal de la acción de activación anarquista en el mundo obrero. ${ }^{284}$ En resumen, la huelga general fue y seguirá siendo durante el período del gobierno peronista, la principal estrategia de acción libertaria en relación al mundo obrero.

\section{Una interpelación generizada y excluyente}

Un elemento que caracterizará las apreciaciones libertarias que veremos en Acción Libertaria y en Reconstruir, a partir de 1946, es la mención al peronismo cada vez que refieran al movimiento obrero. Como veremos, la aparición del mismo en la escena política y sindical presenta al anarquismo la posibilidad y el desafío de elaborar discursos y estrategias políticas concretas sobre la cuestión obrera.

En relación a los discursos que circulan en las esferas públicas alrededor del año 45 , desde $A$. $L$. se previene a los sectores obreros sobre los engaños de ese

\footnotetext{
${ }^{283}$ Suriano describe en su trabajo de manera muy profunda las acepciones, los basamento y los orígenes de la huelga como método primigenio en las luchas obreras del anarquismo en la FORA. Suriano, Juan (2001). Anarquistas...op. cit. También

${ }^{284}$ López Trujillo, Fernando (2005). Vidas en rojo y negro..., op. cit. 
discurso que, aparentemente solidario con sus reclamos históricos, se apropia de los triunfos también históricos de la clase obrera:

"Se habla mucho en las esferas dirigentes del país de elevar el nivel de vida de la clase trabajadora, reconociéndolo lamentablemente bajo. (...) A los impulsos de la lucha suscitada, bajo la formidable presión del movimiento de reivindicación colectiva, se materializó el progreso social y se impusieron auténticas conquistas de dignidad y bienestar para los oprimidos". 285286

Estos sujetos, en este caso, los trabajadores, a los que apela el anarquismo, suponen el sujeto revolucionario que lleva adelante la lucha y lo caracterizan con ribetes heroicos: ese héroe que resiste a los embates y la persecución policial, o que permanece en la calle durante días para sostener el reclamo remite claramente al obrero, al masculino.

"Tales conquistas son válidas, en tanto que logradas por la acción del propio pueblo, con plena conciencia del derecho que le asiste. Nunca en tanto concesiones y dádivas de los poderosos, sean ellos jefes totalitarios, estadistas democráticos o magnates capitalistas". 287288

El ejercicio de apelar a la memoria histórica de las luchas y los reclamos de las izquierdas de los sujetos interpelados, las genealogías de esos procesos y los resultados obtenidos es un mecanismo constante que observamos no solamente en torno a la cuestión obrera, sino también en cuestiones relacionadas con la obtención de los derechos de la ciudadanía política femenina y la participación política de las mujeres. De todos modos, estas estrategias de intervención controversial con respecto a las acciones llevadas adelante por el Perón de la Secretaría de Trabajo y Previsión y posteriormente por el presidente de la nación, son compartidas por el socialismo y también por el comunismo en los mismos años. En cierto sentido,

\footnotetext{
285 “Libertad de Acción para el mejoramiento de la clase obrera”, A.L., № 84, marzo de 1945. Pág. 286

287 “Libertad de Acción para el mejoramiento de la clase obrera”, A.L., Nº 84, marzo de 1945. Pág. 288
} 
desmerecen los medios por los cuales el peronismo logra el triunfo sobre cuestiones caras de la izquierda, reclamando la autoría y la bandera histórica de esas luchas. Como señalara el comunista Marianetti:

“CCon qué derecho se puede decir que nosotros no hemos hecho nada por la clase trabajadora de nuestro país, y lo mismo de los socialistas, cuando ninguno de estos partidos ha tenido el poder en la Argentina?". 289

Ahora bien, esta búsqueda de una genealogía en la que legitimarse implica también un perfil del sujeto interpelado. En este caso, las afirmaciones como los silencios expresan una mirada generizada sobre el mundo del trabajo. En ese caso, el lugar de la mujer obrera dentro de los repertorios de las alocuciones libertarias se presenta contradictorio. Como bien marca Lobato con respecto a las mujeres y su rol en la huelga y las luchas obreras,

"a veces su presencia era subrayada para impulsar la participación de las trabajadoras y otras para mostrar la insensibilidad de los patrones y la crueldad de la policía. Pero en muchas ocasiones se remarcaba su ausencia, porque a las organizaciones sindicales les resultaba dificil compaginar unas prácticas gremiales (...) asociadas con la <virilidad>, la fuerza y la acción organizada con las experiencias de las mujeres donde el trabajo y los tiempos de protestas se encontraban condicionados por las obligaciones del trabajo reproductivo". 290

Resulta iluminadora para nuestra investigación la apreciación de Lobato acerca de que el sindicato fue siempre un lugar masculino, que se sostenía gracias a la acción de sus militantes (hombres) sacrificados que entregaban sus horas de ocio luego del horario laboral, a luchar por mejorar la vida de todos y todas. El honor, el

${ }^{289}$ Marianetti, Benito (1950). Nosotros y la constitución. Mendoza, D’Accurzio. Pág. 72.

${ }^{290}$ Lobato, Mirta Zaida (2007). Historia de las trabajadoras..., op. cit. Pág. $118^{319}$ Ibid. 
coraje y la solidaridad entre iguales (hombres) fueron los valores sobre los que se fundaron los sindicatos. ${ }^{319}$ No podemos olvidar que esta caracterización de los roles sexuados para el mundo obrero y sindical se corresponde con lo que se ha denominado la "ideología de la domesticidad", que al mediar el Siglo XX en la Argentina, impone a las mujeres las tareas del hogar y del cuidado de los hijos, pero también las llama a la participación pública y política. Al mismo tiempo, el mundo laboral ya no está vedado para ellas aunque esto no signifique el quiebre de este modelo. $^{291}$

Los colectivos libertarios determinaron un conjunto de actores (masculinos) y definieron sus identidades de tal modo que se situaron a sí mismos en un "punto de paso obligado", lugar intermedio y obligatorio para lograr los fines que ellos interpretaban, inspiraban a los obreros. Se presentan como imprescindibles en la red de relaciones que estaban construyendo. En el manifiesto del primer número del periódico Reconstruir, encontramos claramente definidos los sujetos a los que se desea enrolar:

"Todos los campos de lucha por los ideales y los métodos que propiciamos serán ampliamente considerados en este periódico: el de los obreros, de los estudiantes y profesores, de los empleados y campesinos, de los maestros y profesionales, de los artistas e intelectuales, de las mujeres y de los jóvenes". ${ }^{292}$

La cita da cuenta de que las trabajadoras no son interpeladas de manera directa en función de sus problemas específicos como tales. Las excepciones parecen confirmar la regla. Son, asimismo, escasamente referenciadas en la prensa libertaria consultada las actuaciones gremiales femeninas, salvo en algunas ocasiones. Así, se sabe que se había dado lugar a una organización de mujeres de la mano del movimiento obrero de tendencia ácrata en Mar del Plata, la Agrupación Femenina de Capacitación y Lucha por los Derechos de la Mujer, mencionada en el capítulo anterior. En el manifiesto que propagan las libertarias se busca, no obstante

\footnotetext{
${ }^{291}$ Scott, Joan (1993). "La mujer trabajadora en el siglo XIX", en Duby, George y Perrot, Michelle (editores). Historia de las mujeres en Occidente. Madrid, Taurus Ediciones.

${ }^{292}$ Reconstruir, $\mathrm{N}^{\circ} 1$, junio de 1946. Pág. 1.
} 
su nombre no lo evidencia, un objetivo de identificación como obreras/trabajadoras (noción que aparece indistintamente mencionada):

"Como mujeres, y especialmente por pertenecer a una agrupación en parte integrada por obreras, que ha nacido en una casa de trabajadores y al calor de las justas aspiraciones proletarias, no podemos permanecer Indiferentes a las inquietudes y las luchas que sostenga la clase obrera en cualquier lugar del país". 293

Los objetivos de movilización de las mujeres estaban colocados en otro plano de interpelación, como vimos en el capítulo anterior, y privilegian su lugar como trabajadoras. En el período peronista, entonces, esta postura contrasta con la trayectoria previa del anarquismo en esa movilización de las mujeres como trabajadoras. Asimismo, lo distingue de las apuestas que sostenía el socialismo, pero más aún, lo colocaba en una enorme diferencia respecto del comunismo que desde la implantación de la política de frentes había abierto sus marcos organizativos para captar a las mujeres de distintos sectores sociales, pero sin descuidar a las obreras y trabajadoras en general. ${ }^{294}$

La especificidad de la cuestión femenina en el mundo del trabajo no aparece tematizada por el universo libertario como un componente fundante para las mujeres de esta organización durante este período. Con todo, cabe mencionar que estas situaciones no fueron exclusivas en relación con el anarquismo. De hecho, algunas investigaciones han subrayado que, salvo en el marco del comunismo que amplió su convocatoria a las mujeres y mantuvo férrea interpelación a las trabajadoras, en el marco del peronismo, la problemática de las trabajadoras se resolvió con un importante grado de invisibilización en algunos discursos significativos - como el de Perón- y en el diseño de políticas sociales. En efecto, algunas autoras, al analizar la situación de las trabajadoras han señalado que el

\footnotetext{
${ }^{293}$ Reconstruir, $\mathrm{N}^{\circ}$ 7, Declaraciones de las obreras de Mar del Plata, septiembre de 1946, pág. 7.

${ }^{294}$ Norando, Verónica (2013). "Relaciones de género y militancia política: Las obreras textiles y el comunismo entre 1936 y 1946", en Trabajos y Comunicaciones, № 39. Norando, Verónica y Ludmila Scheinkman (2011) "Roles sexuales y lucha de clases. La huelga de las obreras de la casa Gratry, Nueva Pompeya, 1936. Género y Clase en disputa", en Razón y Revolución, № 21. Valobra, Adriana (2005) "La UMA en marcha. El Partido Comunista Argentino y las tradiciones y estrategias de movilización social en el primer gobierno peronista: el caso de la Unión de Mujeres Argentinas (UMA)." Canadian Journal of Latin American and Caribbean Studies, № 30 (60): 155-183.
} 
discurso de justicia social tuvo límites al universalismo al no contemplar en particular ni la demanda de igual salario por igual trabajo, las demandas en relación con la Caja de Maternidad ni considerarlas como sujetos de interpelación explícito en los derechos políticos. ${ }^{295}$ Para estas miradas, el problema es que el peronismo no logró romper con los estereotipos de género que atravesaban el arco ideológico en el período y que encontraban enormes dificultades para pensar a las mujeres en el mercado de trabajo. Las alianzas de Perón con la Iglesia Católica y la comunión de amplios sectores del peronismo con estas ideas, habrían reforzado esa mirada. ${ }^{296}$ Otras explicaciones concurren a explicar este hecho. Por un lado, el viraje de estrategias del anarquismo en este período coloca el acento en otras interpelaciones. Por otro lado, los libertarios -ni ningún otro grupo político- no han resuelto en este contexto cuál es el lugar de las trabajadoras. Reclamar por su salario resultaba, evidentemente, un problema que requiere atención para no dar lugar a su explotación; pero, por el otro, hacerlo, supone reconocer que las mujeres encuentran en el mercado de trabajo un lugar que les corresponde, lo cual rompe con el binarismo de género que el anarquismo sostuvo desde los años '30, como hemos visto en el capítulo 1. Como lo expresa Graciela Queirolo, el trabajo femenino fue un problema difícil de resolver para un amplio arco político. Por ello, las posturas conservadoras y revolucionarias se acercaron en este punto. El problema se originaba en la concepción de la actividad laboral femenina que fue entendida por todos como una actividad con tres características. La primera era su carácter excepcional (sólo trabajaban las mujeres cuando eran solteras, separadas, viudas, habían quedado huérfanas o sus esposos o padres -los verdaderos proveedores del hogar- no ganaban lo suficiente para su sustento). La segunda característica era su transitoriedad, vale decir, que la actividad laboral de las mujeres sólo se realizaba por un período de tiempo limitado. Finalmente, se visualizaba el trabajo femenino como si fuera una actividad complementaria a la del varón. Por ello, se consideraba

\footnotetext{
${ }^{295}$ Mirta Lobato, Historia de las trabajadoras..., op. cit.; Karina Ramacciotti, "Las trabajadoras en la mira estatal: Propuestas de reforma de la Caja de Maternidad (1934-1955)", Trabajos y Comunicaciones, $\mathrm{n}^{\mathrm{o}}$ 30-31, 2004/2005, pp. 191-216. Adriana Valobra, Del hogar a las urnas..., op. cit. Ania Tizziani, "El Estatuto del Servicio Doméstico y sus antecedentes: debates en torno a la regulación del trabajo doméstico remunerado en la Argentina”, Nuevo Mundo Mundos Nuevos [En línea], Cuestiones del tiempo presente,.Disponible en http://nuevomundo.revues.org/65153 ; DOI : 10.4000/nuevomundo.65153 (Puesto en línea el 13 marzo 2013, consultado el 08 noviembre 2013). ${ }^{296}$ Lila Caimari, Perón y la Iglesia Católica. Buenos Aires: Ariel, 1995. Lilia Vázquez Lorda, Intervenciones e iniciativas católicas en el ámbito familiar: las ligas de madres y padres de familia (Argentina, 1950-1970), Buenos Aires: Universidad de San Andrés, 2009. Catalina Wainerman, "La mujer y el trabajo en la Argentina desde la perspectiva de la iglesia Católica a mediados del siglo", Desarrollo Económico, Vol. 21, No. 81, 1981, pp. 71-92.
} 
que el varón era quien tenía que realizar las tareas de provisión del hogar y las mujeres sólo “ayudaban" complementándolo cuando no era suficiente. Este punto, además, justificaba salarios más reducidos para las mujeres. ${ }^{297} \mathrm{La}$ invisibilización de las trabajadoras y la ausencia de interpelaciones durante este período hacen patentes estas cuestiones.

\title{
2. La acción sindical: potencia y obstáculos
}

Desde las páginas de los periódicos analizados, percibimos que el anarquismo no se limitó simplemente a identificar unos cuantos y particulares actores. También mostró que los intereses de estos actores residían en admitir la propuesta política, de lucha y de resistencia que ellos habían sostenido. Repitieron constantemente el argumento que habían desarrollado: si el movimiento obrero pretende sobrevivir frente al avance del Estado peronista y del fascismo sobre él, entonces deben construir sus estrategias de la mano del movimiento y las ideas libertarios.

El anarquismo realiza el llamado a los obreros se realiza en clave de "resistencia constructiva", lo que implica firmeza frente a la estatización de sus sindicatos por medio del trabajo ideológico, doctrinario-moral y orgánico:

\begin{abstract}
"Para reconstruir el movimiento obrero hace falta un largo y paciente trabajo de esclarecimiento y de creación militante, partiendo de la base más humilde. Hay que llevar, como hicieron nuestros precursores, el viento de las ideas al taller, a la fábrica, al sindicato obrero, por pequeño e incipiente que él sea. Las hábiles combinaciones burocráticas no dan más que victorias aparentes
\end{abstract}

\footnotetext{
${ }^{297}$ Queirolo, Graciela (2010) "Las mujeres y los niños en el mercado de trabajo urbano (Buenos Aires, 1890-1940)", en Recalde, Héctor (comp.). Señoras, Universitarias y Mujeres (1910-2010). La Cuestión Femenina entre el Centenario y el Bicentenario de la Revolución de Mayo. Granada: Grupo Editor Universitario.
} 
Por otra parte, Acción Libertaria también apela al espíritu de lucha y de resistencia que históricamente ha caracterizado al movimiento obrero como último refugio frente al avance del estatismo en los sindicatos y en las organizaciones sociales en general. "En esos núcleos obreros, en los millares de trabajadores conscientes, obligadamente afiliados a la CGT, se halla el punto de partida y la esperanza de superación del movimiento obrero y la reconquista de las libertades públicas y las libertades sindicales". 299

De todas formas, reconocen que la adhesión obrera al peronismo no se da solamente por la coacción, sino por medios demagógicos como son los aumentos de sueldos, las mejoras en las condiciones laborales, pero fundamentalmente por medio de la corrupción de los dirigentes sindicales. ${ }^{300}$ Los colectivos libertarios no refieren la posibilidad de que la adhesión de los sectores populares al peronismo pueda tener un componente "emocional" o que escape a las acciones dirigidas por parte del Estado para cooptarlos.

En este punto, el anarquismo se asemejaba más a las críticas que provenían desde el socialismo y se diferenciaba de las del comunismo. En todo caso, coacción, demagogia y corrupción formaban parte de una misma perspectiva en la que se desconocían razones fundadas en el apoyo de los obreros a Perón, y en el que se sostenía, como hacía Américo Ghioldi en 1952: "basta conocer el proceso de centralización y de engaño operado en la Argentina para reducir a sus justas y reales proporciones la llamada <obra social>". ${ }^{301}$ En esa lógica, la misma defensa de obtención de mejoras quedaba sospechada de connivencia con el perontotalitarismo, tal lo definía Ghioldi, quien además concluía:

"Se intenta justificar este régimen de iniquidad, preguntándose si no deja alguna obra social realizada ¿Es que acaso es permitido a nadie ni a ningún poder derogar o dar vacaciones a la legalidad

\footnotetext{
298 “Reconstruir el movimiento obrero", Reconstruir, N 1, junio de 1946. Pág. 6

299 "Espíritu de la lucha y resistencia obrera", A.L. № 112, febrero de 1949. Pág. 6.

300 "Salvemos al movimiento obrero de la muerte por corrupción", A. L., No 98, Mayo de 1947.

${ }^{301}$ Ghioldi, Américo (1956). De la tiranía a la democracia social. Buenos Aires, Gure. Pág. 18. ${ }^{331}$ Ibid. Pág. 21.
} 
democrática y a la moral humana para cumplir ésta u otra presunta misión? iSi esto llegáramos a admitir concluiríamos por aceptar la licitud de la tiranía!". 331

De allí que tanto conservadores como Reynaldo Pastor y socialistas como el mencionado Ghioldi, no dudaran en atribuirle al peronismo, no sólo las consabidas homologaciones con el fascismo, sino también con el stalinismo ${ }^{302}$.

El PCA, por su parte, fue el único de los partidos que rápidamente comprendió las implicancias de la acción del matrimonio Perón en la clase trabajadora y asumió una postura que, aunque compleja, no se limitó a la mera oposición: apoyar lo positivo -es decir los puntos del programa peronista que eran comunes al comunismo como el antiimperialismo- y criticar lo negativo; aún a costa de que Perón fuera un anticomunista consumado que no daría lugar a este partido en su gobierno. ${ }^{303}$ El PCA alertaba insistentemente sobre las tendencias autocráticas y maniqueas aunque no dejaba de reconocer la habilidad para llegar a la ciudadanía y expresar de manera sencilla el sentir popular, algo que ni el socialismo ni el anarquismo podían aceptar y los colocó en una postura de confrontación con los que consideraba sus sujetos revolucionarios.

En líneas generales, los conflictos y huelgas obreras planteados por A.L. y Reconstruir coinciden con los enumerados por Doyon. ${ }^{304}$ Según la interpretación de esta autora, las huelgas se dan en consonancia con la ampliación de las políticas implementadas por decreto pero que aún no habían sido institucionalizadas en el medio laboral. Sin embargo, a partir de nuestras observaciones sobre la forma en que A. L. y Reconstruir conciben los conflictos, intuimos que para los anarquistas la huelga da cuenta de una oposición política al régimen. Esto indica que en la concepción anarquista las huelgas eran pensadas en correlación con una matriz político-ideológica y no solo como un reclamo sobre derechos. De esta manera podríamos matizar la propuesta de Doyon de que las huelgas del período se daban en consonancia con un proceso de negociación "pragmática" que se reducía a

\footnotetext{
${ }^{302}$ En el caso de Ghioldi, diciendo: "En la Argentina como en Rusia, el gobierno paternalistaobrero obtiene recursos imponiendo gabelas y toda suerte de exacciones al salario de los trabajadores". Ibid. Pág. 20.

${ }_{303}$ Altamirano, Carlos (2001). Peronismo y cultura de izquierda. Buenos Aires, Temas.

304 Doyon, Louise (1977) "Conflictos obreros durante el régimen peronista (1946-1955)", Desarrollo Económico, Vol 17, Nº6, oct-nov.
} 
reclamos exclusivamente la de mejoras laborales y en la condición de vida de los trabajadores. Las interpretaciones libertarias nos permiten reestablecer las intenciones políticas de los trabajadores, dotándolos -a su vez- de capacidad de expresión política. ${ }^{305}$

Según los libertarios, el camino para lograr la generalización de la huelga y el enrolamiento de los obreros en las ideas y acciones libertarias estaba bloqueado por una serie de obstáculos/problemas. Uno de ellos es la corrupción, enquistada en las prácticas del movimiento obrero e introducida por la Confederación General de los Trabajadores (CGT) con anterioridad a la llegada del peronismo. ${ }^{306}$ La CGT también es visualizada como responsable del enmascaramiento y la distorsión de la "realidad" social, cooperando de esta manera con el estado peronista:

"Instrumento incondicional del gobierno, de quien reciben sus dirigentes los favores que premian a la burocracia más próxima a la pareja reinante, La C.G.T. cumple su triste y vergonzosa misión mintiendo y falseando los hechos con el descaro que cuadra a los lacayos de un régimen totalitario". ${ }^{307}$

La historiadora Mercedes Prol asegura que la CGT es un componente indispensable para comprender de qué manera articula la participación popular en un sistema que antes que democrático y participativo, se presenta en base a alianzas corporativas:

"Se generó un proceso de creciente corporativización de la política, que tuvo como protagonistas principales, en una primera etapa, a las elites estatales y al movimiento obrero organizado, nucleado en la Confederación General del Trabajo. La Central adhirió al gobierno peronista, apoyó el curso de la política económica del mismo y se convirtió en 1951 en la tercera rama del Movimiento Peronista,

\footnotetext{
${ }^{305}$ Por ejemplo, en un artículo aparecido en A.L., "El ideario Anarquista señala el camino para la liberación" se traza una genealogía sobre los referentes teóricos históricos del anarquismo (Malatesta, Bakunin, Fabbri, etc.) poniendo énfasis en las citas que refieren a la organización federativa como propuesta positiva del anarco comunismo frente al totalitarismo. A.L, $\mathrm{N}^{\circ} 98$, mayo de 1947.

${ }^{306}$ A.L, No $\mathrm{N}^{\mathrm{0}}$ 98, mayo de 1947.

307 "LA C.G.T mistifica la realidad argentina", A.L. No 115, julio de 1949
} 
disputando espacios de poder al Partido Peronista rama masculina y

al Partido Peronista Femenino. Los lazos informales entre gobierno y

CGT se desplegaron en el plano de la selección de los liderazgos

dentro de la Central obrera y en algunos sindicatos." ${ }^{308}$

En coincidencia con este análisis, percibimos en los colectivos libertarios consideraciones que se perfilan asimilables con las interpretaciones de Prol: la caracterización de este sistema "pseudo democrático" tiene en la CGT el principal aparato para su funcionamiento. 309

Otros obstáculos para la implementación de esas estrategias de lucha son la falta de coordinación entre las agrupaciones obreras y sindicales que se oponen a la política oficial cuestión por la cual la resistencia y las luchas obreras no son visibles para el resto de la sociedad y la acción socavadora e interesada que ejercen los comunistas en los sindicatos siguiendo los lineamientos del gobierno ruso. ${ }^{310}$

Así, desde esta concepción, el presente-futuro del movimiento obrero está permanentemente amenazado. Al mismo tiempo, para los libertarios, la disyuntiva para los obreros es clara: o cambian de conducta y se suman a la organización anarquista (el movimiento obrero se vuelve revolucionario dejando abandonadas las prácticas que lleva delante de la mano del sindicalismo oficialista) o el triunfo del capitalismo-fascismo es inexorable. Si se opta por la primera, el anarquismo aporta con su historia de triunfos para demostrar que el cambio es posible:

“Todas las grandes revoluciones necesitaron destruir ciertos prejuicios de las masas, poniéndolas en condiciones de comprobar

\footnotetext{
308 Prol, María Mercedes (2008). “Arreglos institucionales en el régimen político del primer peronismo (1946-1955)", en Nuevo Mundo Mundos Nuevos, http://nuevomundo.revues.org/12592\#quotation. También Del Campo, Hugo (1983). Sindicalismo y peronismo. Los comienzos de un vínculo perdurable. Buenos Aires, Clacso. Doyon, Louise (2006) Perón y los trabajadores. Los origenes del sindicalismo peronista, 1943-1955. Buenos Aires, Siglo XXI Editora Iberoamericana.

309 "La CGT mistifica la realidad argentina", en A.L., N N $^{\circ} 15$, julio de 1949.

${ }^{310}$ Ibid. Sobre la participación del comunismo en los sindicatos y conflictos obreros durante los dos primeros gobiernos peronistas, Schiavi propone descartar las tesis que afirman la desaparición brusca del comunismo en el mundo sindical a partir de 1946. centrándose en los casos de los trabajadores textiles y metalúrgicos. Schiavi, Marcos (2012). "Los sindicatos comunistas entre el 17 de octubre y su disolución. El caso textil y metalúrgico.”, en Revista Trabajadores, $\mathrm{N}^{\circ} 3$. http://www.revistatrabajadores.com.ar/index.php/Trabajadores/article/view/21.
} 
sus viejos errores. Nada mejor que la experiencia para demostrar una verdad discutida. Nosotros ofrecemos varias experiencias revolucionarias que demuestran la viabilidad de las de las soluciones libertarias, a pesar de haber sido parciales, de haber sido superadas por fuerzas que en nada invalidaron su razón ni pueden destruir las enseñanzas positivas que nos legaron. En todas ellas con matices distintos, fue probada la capacidad creadora del pueblo, la posibilidad de una reconstrucción social a cargo de los trabajadores mismos, basada en el verdadero socialismo, Méjico, Rusia, Baviera, Hungría y España sobre todo, han aportado esos ejemplos, escritos con la sangre de sus mejores hijos", 311

Así, con su historia de revoluciones "efectivas", el colectivo libertario resulta indispensable para el porvenir del movimiento obrero.

\section{La "dignidad proletaria" y la demagogia peronista}

La "dignidad proletaria" será uno de los enunciados mediante los cuales el colectivo libertario identifique al movimiento obrero que da muestras de resistencia al totalitarismo /peronismo.

En relación a una serie de reclamos llevados adelante por el Sindicato Gráfico de La Plata (en el cual son mayoría los cuadros libertarios faquistas encabezados por Luis Danussi), la cuestión a resaltar es el ejemplo aleccionador que representan estas acciones y destacar cierta "naturaleza revolucionaria" como quintaesencia del obrerismo:

\section{“(...) en el seno de la clase trabajadora existen las suficientes reservas morales como para alentar posibilidades de una profunda recuperación de su independencia y combatividad. Que en el espíritu y el corazón de los trabajadores argentinos, aún no ha muerto, pese a}

\footnotetext{
311 "Experiencias valiosas confirman la practicidad de nuestras ideas", A.L, No 106, mayo de 1948. 
la acción demagógica y corruptora del peronismo, el espíritu de dignidad y de independencia de la que tanto habla su historia". 312

También, dan una cuota de confianza para que aquellas organizaciones obreras que se acercaron al peronismo puedan retomar el "buen camino", el natural de la clase obrera:

"esta lucha de los trabajadores gráficos, acariciará como un soplo alentador y tonificante, a todos aquellos que no cejan en su empeño para que las organizaciones obreras, dejen de ser puntales de la reacción y el totalitarismo, y se transformen nuevamente en el instrumento de liberación de la clase trabajadora, donde desde ya, se templa el espíritu para la lucha y se aprende a vivir en solidaridad". 313

En este momento, los "triunfos" de las luchas obreras en relación a reclamos puntuales frente al estado no son ajenos al colectivo libertario. Puntualmente, llamarán su atención las huelgas de lo obreros panaderos de Capital Federal llevadas adelante entre fines de 1945 y mediados de 1946 y que darán por resultado el reconocimiento de la jornada de trabajo diurna. En este caso, se destaca la acción solidaria entre los sindicatos que ideológica y tácticamente están distanciadas (como los asociados a la Federación Obrera Regional de la Argentina y la Federación Obrera Nacional de la Industria del Pan) y cuyo fin es no solamente lograr mejoras en la vida de los trabajadores, sino también oponerse al régimen peronista. En estos casos, la mirada del anarquismo considera que los resultados obtenidos no dependen de la capacidad "negociadora" de los sindicatos o de la buena predisposición del Estado para resolver los conflictos y dar respuesta a las

\footnotetext{
312 "Sindicato Gráfico de La Plata" A.L. No 112, 1949. Sobre la participación de Luis Danussi en el movimiento obrero y libertario, remitimos al trabajo de: Grunfeld, José y Jacinto Cimazo (1981). Luis Danussi, en el movimiento social y obrero argentino. 1938-1978. Buenos Aires, Proyección. Sobre el mismo proceso de la huelga de los gráficos de febrero de 1949, otro dirigente alineado con la Federación Gráfica Bonaerense y la FATI, relata la actuación de Danussi en el conflicto acompañando a dirigentes de otras tendencias políticas no ligadas al anarquismo: "En febrero de 1949, se produce la gran huelga que duró un mes. Danussi actuó junto a compañeros como José Cosín, Agustín García, entre otros. Después, el gremio fue intervenido. La FATI fue llevada a Rosario y posteriormente sobrevino un largo período de inactividad (...)." Doumerc, Fernando (1980). "Gastó energías e inteligencia sin medida", en Grunfeld, José y Jacinto Cimazo. Luis Danussi... op. cit. Pág. 293.

313 "Experiencias aleccionadoras del conflicto Gráfico", A.L, op. cit. Pág. 10
} 
demandas, sino de la acción militante y solidaria de quienes llevan adelante el reclamo.

"Los obreros panaderos acaban de obtener la abolición del trabajo nocturno. Esta vieja aspiración del gremio ha sido lograda después de un intenso trabajo de organización y propaganda en todo el país. Han coincidido en esta lucha, que señala un vigoroso resurgir del espíritu combativo del gremio, organismos sindicales hasta ayer separados por profundas y casi irreconciliables concepciones tácticas ". 314

El mismo mecanismo aparece cada vez que explican un conflicto obrerogremial: los obreros madereros, los plomeros y cloaquistas, los bancarios, los gráficos, los ferroviarios y los portuarios. ${ }^{315}$

Si es posible una generalización, las características de este movimiento obrero al que apelan es o debe ser: solidario, independiente, combativo, revolucionario, antitotalitario/antiperonista. Así, estos componentes de la identidad "obrera" funcionan al mismo tiempo como medio de enrolamiento, como una manera de llamar a quienes se identifiquen con estas características. Este proceso de darle identidad e identificar al movimiento obrero con determinadas características, contiene al mismo tiempo la identificación/identidad "negativa", la de aquellas fracciones del sindicalismo y del movimiento obrero que definitivamente no se alinean con las ideas anarquistas porque se alinean con el peronismo y el sindicalismo que le es afín. En el caso del movimiento obrero, el interesamiento se basa en una interpretación sobre lo que son y lo que quieren los actores a los que se intenta enrolar, así como sobre con qué otras entidades están asociados. Según Callon, para todos los grupos involucrados, el interesamiento

"acorrala" a las entidades que se pretende enrolar. Pero además, intenta interrumpir todas las asociaciones potencialmente competitivas con la suya y edificar un sistema de alianzas.

\footnotetext{
${ }^{314}$ Lo podemos ver en "Los trabajadores del pan logran la jornada diurna", Reconstruir, $\mathrm{N}^{\circ} 4$, agosto de 1946, Pág. 4.

${ }^{315}$ Reconstruir, No 4, agosto de 1946, Pág. 4. 
Un ejemplo de este mecanismo aparece en Reconstruir, cuando se trata de "traducir" lo que el movimiento obrero "necesita" en la ciudad de Tres Arroyos:

\begin{abstract}
"El panorama obrero de Tres Arroyos ofrece actualmente la existencia de una buena cantidad de organizaciones que, aunque diferenciadas por su interpretación de la lucha, constituyen de por si toda una fuerza orgánica y con potencial combativo. Pero les falta a estos núcleos un nexo que coordine los esfuerzos solidarios en la lucha común contra la explotación capitalista, dándoles unidad y firmeza". 316
\end{abstract}

Ese nexo sería la creación de una Unión Obrera Local, como las que preexisten en Mar del Plata y La Plata y que son la apuesta organizativa novedosa del colectivo ácrata a partir de $1940 .{ }^{317}$ Diego Abad de Santillán ha mencionado la existencia de las Uniones Obreras, agrupamientos de afinidad anarquistas que conviven con otros repertorios de organización en tiempos de hegemonía de la FORA, máxima organización del anarquismo entre 1910 y 1930. El autor describe la naturaleza de las uniones obreras, las que parecerían funcionar de manera similar a las sociedades de resistencia anarquistas. ${ }^{348}$ Las Uniones Obreras Locales (UOL), que comienzan a aparecer alrededor de 1940 en algunas ciudades, son impulsadas y sostenidas por los miembros de la FACA, tendrán el apoyo y sostendrán un trabajo mancomunado con las USL a partir de 1946. Se trata de agrupaciones que reúnen a obreros y trabajadores de distintas actividades y ramas industriales, y que fundamentalmente en los años de nuestro estudio, se oponen a al enrolamiento sindical vinculado con el Estado, la CGT y los gremios afines al gobierno. La USL de La Plata propone que dentro de las UOL, es necesario realizar un trabajo no solamente sindical y relacionado con los reclamos obreros, sino también cultural en cuanto espacio de lectura, intercambio y formación política. ${ }^{349}$ LA UOL de La Plata, se compone al mismo tiempo de otras organizaciones locales, como se demuestra Reconstruir:

\footnotetext{
316 "En Tres Arroyos se hace sentir la necesidad de una Unión Obrera Local”, en Reconstruir, № 5 , agosto de 1946. Pág 8.

${ }^{317}$ Los repertorios organizativos del anarquismo en este período ya los he analizado con anterioridad en Bordagaray, María Eugenia (2011). "Anarquismo en la Argentina. Repertorios
} 
"Inmediatamente después de constituido el nuevo Consejo se ha abocado a la preparación de una reunión de organizaciones locales a fin de aunar ideas acerca de la realización de un acto público contra la carestía de la vida. Se estudiará también la posibilidad de lograr la unidad obrera local en torno a la central sindical citada. También se auspiciará una campaña tendiente a conquistar una ley de seguro para los trabajadores de la industria". 350

organizacionales y de acción colectiva en el movimiento libertario, 1935-1955" en Revista Repertorio Americano, Segunda Nueva Época, $\mathrm{N}^{\circ}$ 21, Universidad Nacional de Costa Rica.

${ }^{348}$ Diego Abad de Santillán (2005). La FORA..., op. cit.

${ }^{349}$ Informe USL de Buenos Aires (1948). En el mes de septiembre de 1946, Reconstruir informa sobre la formación de un nuevo consejo directivo para la UOL de La Plata: Secretario General, Alberto Fernández Leys; Prosecretario, Manuel González; secretario de actas, Doroteo Báez; tesorero, Antonio Grossa; protesorero, Omar Lizarralde; contador, Julio Di Jorge; vocales: Marcos Brescacini, Amador García, Armando Bielmi, Domingo Quinteros; revisores de cuentas: Juan Fila, Juan Gironda, Oscar Moabro. "Se ha reorganizado el Consejo de la Unión Obrera Local de La Plata", Reconstruir, Nº 6, Septiembre de 1946.

350 "Se ha reorganizado el Consejo de la Unión Obrera Local de La Plata", Reconstruir, $\mathrm{N}^{\circ}$ 6..., op. cit. Pág. 4.

En una sola cita podemos vislumbrar tres estrategias de acción diferenciadas por parte de la UOL de La Plata. El acto por la carestía de la vida implica un llamamiento amplio a toda la población, los intereses que se persiguen implican a toda la población. En segundo lugar, un intento por coordinar organizaciones obreras y sindicales bajo la dirección de la UOL. Por último, un reclamo laboral concreto, el de una ley de seguro laboral, que interpela incluso a los sindicatos opositores y que pretende, en su alocución, establecer un espacio de diálogo con el Estado.

El potencial del agenciamiento libertario en Mar del Plata residiría según Reconstruir, en la existencia de una gran cantidad de obreros agremiados, en donde si bien la mayoría no se encuentra ligado a ninguno de los sindicatos de orientación anarquista, las inquietudes que parecen movilizarlos indican la urgencia de la actuación de los libertarios en pos de llenar ese vacío organizativo. Este es uno entre varios ejemplos que presentan las publicaciones analizadas. El primer número de su publicación homónima data del año $1943 .{ }^{318}$ Nieto describe el ímpetu de las

\footnotetext{
${ }^{318}$ Sólo hemos hallado el número 14 del periódico, correspondiente al año 1946.
} 
Juventudes Libertarias de Mar del Plata en cuanto a organizar la creciente industria pesquera.

“Corría el año 1942 cuando, en la búsqueda de revertir la falta de organización sindical, los/las militantes de las JJ.LL. se lanzaron a organizar un primer grupo de obreras/os de la industria. Lo primero que hicieron fue contactarse con una obrera del pescado que era la mujer de un militante anarquista de otro gremio, conjuntamente escribieron una nota que apareció en Avanzada! (el periódico de la Juventudes Libertarias de Capital Federal). Varios ejemplares de esa tirada se destinaron a las JJ.LL. de Mar del Plata para que sus militantes pudieran desarrollar la campaña pro organización entre las trabajadoras/es de la industria". 319

Las acciones conjuntas de los/las trabajadores/as lleva a la constitución del Sindicato Obrero de la Industria del Pescado (SOIP) en 1942. Vinculado en acciones conjuntas con la UOL, ambos desaparecen de la escena política de la ciudad en 1948. LA UOL es clausurada en 1947 y el SOIP intervenido. ${ }^{320}$

De este modo, es posible pensar las estrategias organizativas del anarquismo con respecto al mundo obrero desde una perspectiva amplia. Los casos de organizaciones locales como los de La Plata o Mar del Plata y el trabajo en solidaridad con otros espacios, tiene coincidencia con las apuestas generales impulsadas por la FACA y las USL. Sin embargo, las posibilidades de enrolamiento con respecto al sujeto trabajador están sujetas al grado de negociación-diálogo que estos repertorios organizacionales logran establecer con las demás fuerzas políticas, sindicales y con el Estado al mediar en los conflictos.

\footnotetext{
${ }^{319}$ Nieto, Agustín (2011). "Activación obrera y democracia. Experiencias micropolíticas de un grupo subalterno: Las obreras/os del pescado, Mar del Plata (1942-1966)", en A contracorriente..., op. cit.

${ }^{320}$ Ibídem
} 


\section{La huelga como posibilidad de agenciamiento anarquista}

A partir de 1948, se percibe en la prensa libertaria que las mejoras en las condiciones de vida de los trabajadores (consecuencia de la suba de salarios, nuevos regimenes laborales y reconocimiento por parte del Estado de sus derechos políticos y sociales) han ejercido -según la óptica del anarquismo- un efecto devastador para la agitación obrera, para la independencia sindical y para el movimiento libertario que pretende agitar a los trabajadores. ${ }^{321}$ En lenguaje de Callon, en este momento de la controversia, se está luchando una verdadera batalla. ${ }^{322}$ En nuestro caso de estudio, la dádiva y la corrupción son sólo algunas de las fuerzas que se oponen a las alianzas que los libertarios quieren forjar con los obreros.

"Ni la dádiva ni el soborno, ni las amenazas ni las persecuciones que han sido elementos predilectos que el oficialismo ha puesto en juego para destruir en su esencia al movimiento obrero organizado, atacando los sentimientos más nobles del pueblos trabajador". 323

Los anarquistas están dispuestos a hacer cualquier concesión con tal de atraer obreros a sus filas y alejarlos del sindicalismo oficialista. Concesión, en el sentido de subsumir sus propios preceptos ideológicos al abandonar la idea de huelga revolucionaria y proponer que una huelga puede ser negociada o incluso que se puede dar un proceso de acumulación de derechos aunque la huelga sea derrotada. En tal sentido, interpretan la vuelta al trabajo de plomeros y cloaquistas (luego de una huelga que duró 50 días en la ciudad de Buenos Aires y que terminó con la negativa a los reclamos de mayores salarios por parte de la patronal y la intervención del gobierno a favor de esta última) como un "triunfo" del movimiento obrero:

\footnotetext{
${ }^{321}$ Numerosas son las menciones de este tipo. Algunos ejemplos en "En la recuperación combativa de los gráficos se manifiestan las reservas morales del proletariado", A. L. No 111, febrero de 1949; "Noticiario Sindical", A. L. No 115, julio de 1949;

${ }^{322}$ Callon, Michelle (1986). "Some elements...," op. cit.

323 "Con cárcel, militarización y cesantías castiga el gobierno la dignidad de los obreros ferroviarios", A. L. No 129, mayo de 1951. Lo mismo con respeto a la CGT: "La CGT. Encarnación de servilismo y traición", A. L. No 129, op. cit.; o "La CGT en función de policía política”, A. L. No 137, agosto de 1952
} 
"Las extraordinarias medidas determinaron al Comité de Huelga para evitar mayores sacrificios al gremio- a adoptar responsablemente la resolución de dar la vuelta al trabajo. Así terminó, de momento, un conflicto que, de no gravitar todos los factores del régimen justicialista, habría culminado en una solución triunfante para los obreros. Esta nueva experiencia vivida en toda su intensidad durante casi dos meses por los Plomeros, Cloaquistas, Hidráulicos y Anexos, brinda una nueva y terminante lección señalando fundamentalmente a todo el proletariado del país que su única salvación radica en la conquista de la libertad y la independencia sindical", 324

De este modo, alcanzaría con enrolar a aquellos que simplemente plantean acciones puntuales, aunque sea de mínima resistencia, pero que planteen algún tipo de reclamo a la patronal o al estado. $Y$ en este sentido entendemos la alianza que a partir de 1953 establecerá con la F.O.R.A. "La F.A.C.A. declara su solidaridad con la campaña de los obreros portuarios de la F.O.R.A y saluda la nueva convivencia libertaria". ${ }^{325}$ Las diferencias ideológicas y programáticas entre F.O.R.A y F.A.C.A, fundamentalmente en relación a quién es el sujeto revolucionario, cuales son los métodos de lucha y cuál es el objetivo de la misma determinaron que fuese imposible el trabajo en colaboración. ${ }^{326}$ Esto no quiere decir que "debieron" haberlo hecho solo por llamarse "anarquistas" tanto unos como otros, como lo ha sugerido la historiografía que ve al anarquismo limitado a lo actuado por la F.O.R.A. El punto de discusión entre ambas organizaciones a partir de 1940 será cuál es el tipo o la forma de organización obrera necesaria: la F.O.R.A piensa en sindicatos por oficio y F.A.C.A en sindicatos por industria.

"Liberarse de la dictadura" es la acción que debe llevar adelante el movimiento obrero para la FACA. ${ }^{327}$

\footnotetext{
324 "Los plomeros y cloaquistas han vuelto al trabajo", A. L. N $\mathrm{N}^{\mathrm{0}} 137$, agosto de 1952. Pág. 3 ${ }^{325}$ A.L. $\mathrm{N}^{\mathrm{o}} 138$, febrero de 1953.

${ }^{326}$ Las diferencias ideológicas y programáticas entre FACA y FORA han sido abordadas en la introducción y el capítulo 1 de la presente investigación.

${ }^{327}$ A.L., $\mathrm{N}^{\mathrm{o}} 138$, febrero de 1953
} 
La pregunta que parece clave en este momento es: ¿Qué se necesita para que el movimiento obrero lo haga? Según José Grunfeld, lograr triunfos en pequeñas escaramuzas alienta a realizar obras de mayor envergadura, evitando momentáneamente los grandes proyectos, "pues todos ellos tienen muchas posibilidades de fracasar y los fracasos son muy graves en organismos de origen popular a los que concurren personas no formadas y poco propensas al sacrificio". ${ }^{328}$ Da por sentado que la mayoría de los obreros que participan en los sindicatos pertenecen a esos "nuevos trabajadores" con poca experiencia en las luchas obreras, que buena parte de la historiografía ha señalado como fundante del anclaje obrero y popular del peronismo.

Nos interesa analizar aquí cuán representativos (cuantitativamente) son los obreros "interesados" por el anarquismo. La pregunta es sobre la validez del llamado del colectivo libertario y su eficacia en convocar a los obreros, es sobre la "cantidad". Lo que los libertarios quieren saber al "contar" los obreros que realizan acciones de oposición es con qué pueden contar en sus discusiones y acciones con el peronismo, la CGT y el comunismo. Contarlos implica posicionarse dentro de la arena de disputa política, implica visibilizarse como colectivo político que aún representa a las fuerzas populares y que encarna los reclamos populares frente a la hegemonía del peronismo tanto en el Estado como en el mundo sindical.

La simetría planteada por los actores es la siguiente: movimiento obrero es igual a resistencia obrera, lo que los lleva asegurar que los obreros son por naturaleza e historia "revolucionarios". Si esto es así, entonces no existen distancias en los objetivos del movimiento obrero revolucionario y el "socialismo libertario". Y el socialismo libertario (como ideología, como fin último de la revolución, como sociedad futura) es igual al anarco-comunismo detrás del cual se embanderan tanto la FACA como Reconstruir.

Ahora bien, de la solidez de la red de equivalencia que definirá quién resulta el portavoz, dependerá el desenlace de esta controversia que hemos planteado porque a fin de cuentas, una controversia es el conjunto de expresiones mediante las cuales se cuestiona, discute, negocia, rechaza, entre otras acciones, la representatividad de un portavoz. Y llegados a este punto, no solo es necesario dar

328 “Colaboración de José Grunfeld”, A.L, № 106, Mayo de 1948. 
cuenta de la aceptación o grado de participación que tuvieron las ideas anarquistas dentro de lo que ellos mismos llamaron movimiento obrero revolucionario, sino también de qué grado de reconocimiento tuvieron por parte de los contendientes con los que plantean la disputa, con los que establecen la controversia. Nos remitiremos a aquellos trabajos que desde la historiografia han echado luz sobre las características del movimiento obrero y del sindicalismo en estos años, como así también a aquellos trabajos que abordan la relación o grado de reconocimiento que el peronismo en el gobierno otorga a la oposición dentro del mundo obrero y sindical.

El decreto 23.852, dictado el 2 de octubre de 1945, estableció las bases para la institucionalización de las organizaciones sindicales, otorgándoles un lugar privilegiado en su interlocución con el Estado como actores sociales y políticos. Partiendo de reconocer un conjunto de derechos exclusivos a la organización más representativa (a aquella que contara con mayor cantidad de afiliados, en un determinado ámbito de actuación), el Estado otorgaba la "personería gremial” a la organización que contara con mayor representatividad (al mismo tiempo que podía suspenderla o quitarla ante una violación de las disposiciones legales, estatutarias o de un contrato colectivo de trabajo, o frente a una disminución del número de afiliados en forma tal que dicha organización dejara de revestir el carácter de suficientemente representativa). ${ }^{329}$ Según el investigador Luis A. Campos, las disposiciones de este decreto condujeron a la consagración de una estructura sindical vertical y centralizada, fundamentalmente a partir del otorgamiento de la personería gremial a uniones o sindicatos que tengan estructura en el ámbito nacional. El decreto de 1945 llevó a que las organizaciones de ámbito nacional contaron con el apoyo del sistema normativo para concentrar y centralizar la actividad sindical dentro de sus ramas de actuación. Este proceso se realizó por una doble vía: por un lado, al obtener el reconocimiento de su personería gremial, se ubicaron como interlocutores privilegiados en la intermediación de los intereses de

\footnotetext{
329 Según Campos, el decreto 23.852 de 1945 reconoce la posibilidad de conformar múltiples sindicatos en un mismo ámbito y otorga un extenso conjunto de derechos exclusivos a quien obtenga el reconocimiento estatal como más representativo (personería gremial). Esto posibilita un fuerte control vertical de las organizaciones sindicales por parte de los niveles superiores de la estructura (federaciones y uniones), principalmente a través del control de los fondos sindicales y de las facultades disciplinarias. Así, el Estado cuenta con grandes atribuciones para intervenir en los asuntos internos de las organizaciones sindicales. Campos, Luis A. (2008) Extracto de tesis presentada en la Maestría de Economía Política con mención en Economía Argentina, de la Facultad Latinoamericana de Ciencias Sociales (FLACSO)
} 
los trabajadores del sector, situación que beneficiaba particularmente a los sindicatos con menor desarrollo organizativo previo (los que aparecen puntualmente a partir de 1943); por el otro, pudieron desarrollar crecientes mecanismos de control vertical intrasindicales, a partir de la administración de los fondos sindicales y de su capacidad de intervenir a las instancias inferiores.

Sin embargo, la complejidad del escenario planteado por Campos no se resuelve en el ámbito jurídico, es decir, el decreto no condujo automáticamente a la verticalización y centralización del movimiento obrero. Este proceso fue disputado por los propios trabajadores en los espacios de trabajo y por las dirigencias sindicales no peronistas. Numerosos abordajes recientes visibilizan el proceso de puja en el espacio laboral y entre corrientes políticas como el socialismo y el comunismo por el control de algunos sindicatos.

"Las comisiones internas se convirtieron en unas de las piedras angulares del sindicalismo argentino a partir de mediados de siglo XX. Recientes investigaciones han demostrado que sus orígenes se remontan a la década 1930. Los sindicatos comunistas fueron sus primeros impulsores. De esta manera se relativizó la relación directa entre comisiones internas y modelo sindical peronista. Entonces, es posible pensar que más que su creación, las comisiones internas le fueron impuestas al gobierno peronista". 363

Esta dinámica implicó una reconfiguración de la estructura sindical existente en nuestro país (sin desconocer las transformaciones económicas y sociales previas dadas por la creciente industrialización a partir de 1940), provocando un proceso de centralización sindical y de unificación de la representación sindical en torno a aquella organización que contara con la personería gremial y de un aumento muy significativo de los niveles de afiliación sindical a las mismas. El nuevo panorama debilitó aún más las acciones de los anarquistas dentro del mundo sindical y de las organizaciones obreras. 


\section{5- Consideraciones finales}

Así como hemos descripto a partir de la problematización, que en la metodología propuesta implica describir un escenario de posibles aliados frente a un "otro" con quien se los disputa, la cantidad de los posibles aliados obreros compromete la mayor parte de las acciones libertarias.

A través de la prensa analizada, se aprecia que los anarquistas establecen una simetría entre el movimiento obrero en general y el sector del movimiento

${ }^{363}$ Schiavi, Marcos (2012). “Organización y conflictividad textil: La Fábrica Argentina de Alpargatas a comienzos del primer gobierno peronista”, en Revista Mundos do Trabalho, Vol. 4, No 8. Disponible

https://periodicos.ufsc.br/index.php/mundosdotrabalho/article/view/19849222.2012v4n8p252. Sobre este tema, existen trabajos señeros como por ejemplo James, Daniel (1981). "Racionalización y respuesta de la clase obrera: contexto y limitaciones de la actividad gremial en la Argentina" en Desarrollo Económico, Vol. 21, nº 83, octubre - diciembre.

Mainwaring, S. y Seibert, S. (1982). "El movimiento obrero y el peronismo, 1952-1955.” Desarrollo económico, Vol. 21, $\mathrm{N}^{\circ} 84$.

obrero que plantea algunas disidencias con el poder, al evocar y visibilizar los conflictos (que algunas agrupaciones sindicales o gremiales le plantean a la patronal, al estado o a la CGT).

Finalmente, durante este mismo período, las organizaciones sindicales desarrollaron una fuerte presencia en los lugares de trabajo, a partir de la designación de delegados y comisiones internas, lo que implicó el desplazamiento de aquellos núcleos de obreros orientados por las ideas no oficialistas, o por lo menos, las que planteaban dudas con respecto a un sindicalismo organizado desde el Estado. Así, las acciones de los miembros de la FACA en las comisiones internas de las fábricas y las Uniones Obreras Locales fueron afectadas por esta nueva situación planteada por el peronismo.

La poca presencia del anarquismo en el movimiento obrero no solo debe explicarse por las desavenencias impuestas por el peronismo, sino que es necesario pensar en el mediano plazo que lo precede, los años en los que el anarcosindicalismo aún contaban con numerosos seguidores en las filas obreras. 
Es por ello que podemos constatar que ni todo es coacción por parte del Estado ni todo es fracaso por parte de la FACA en su inserción en el movimiento obrero.

Volviendo a la pregunta acerca de si son representativos los portavoces enrolados en la cadena de equivalencias, podemos aventurar una respuesta negativa, ya que lo que en líneas generales nos demuestra la historiografía y las propias crónicas de los militantes libertarios es la poca representación que entre los trabajadores tienen las ideas anarco-comunistas en los años del peronismo. ${ }^{364}$

${ }^{364}$ Ver por ejemplo Grunfeld, José (2000). Memorias..., op. cit. También Jacinto Cimazo (1995) Escritos Libertarios..., op. cit. Sobre la bibliografía, remitimos a los trabajos más significativos dentro de la historiografía reciente: Doyon, Louise (1984). "La organización del movimiento sindical peronista 1946 - 1955”, en Desarrollo Económico Vol. 24 N 94 (julio - septiembre; James, Daniel (2006). Resistencia e integración. El peronismo y la clase trabajadora argentina,

1946 - 1976. Buenos Aires, Siglo XXI; Little, Walter (1979). "La organización obrera y el estado peronista, 1943 - 1955”, en Desarrollo Económico Vol. 19 № 75 (octubre - diciembre); Schneider, Alejandro (2005). Los compañeros. Trabajadores, izquierda y peronismo, 1955 - 1973. Buenos Aires, Ediciones Imago Mundi; Torre, Juan Carlos (2004). El gigante invertebrado. Los sindicatos y en el gobierno, Argentina 1973 - 1976, Buenos Aires, Siglo XXI.

Sin embargo, la metodología propuesta nos permite abordar el estudio de aquellos grupos que fueron subalternizados por los discursos hegemónicos, en el sentido de que fueron interpretados como "anacrónicos" o directamente invisibilizados en su accionar. Este es el caso del anarquismo, es el caso de F.A.C.A., de Reconstruir y de todos aquellos que actuaron bajo el ala del anarcocomunismo en tiempos del peronismo en el poder. Es posible profundizar en sus acciones-discursos planteados en término de tensión-diálogo con otros actores en la diacronía (las demás fuerzas políticas, el peronismo en el estado, la CGT, etc.) a partir de identificar a qué sujetos pretende "interesar". Apelar al movimiento obrero en tiempos del peronismo es entablar una lucha-controversia por los sentidos y la identidad de ese colectivo heterogéneo y amorfo pero de primer orden tanto en la historia del anarquismo como en la construcción del peronismo.

Porque por otra parte, la disputa acerca de la representatividad pareciera ser más útil para la legitimidad política que para la observación historiográfica. En ocasiones, es en lo que parece marginal, en el campo de lo que aparece como “anómalo", según nos ha recordado Carlo Ginzburg, en donde pueden verse marcas 
sociales más profundas que las pinceladas gruesas que muestran los discursos explícitos de lo "representativo de una época". 330

\section{Capítulo 5}

\section{SUJETOS DE LA ÚLTIMA TRINCHERA CONTRA EL "FASCISMO CRIOLLO"}

La historiografía sobre los universitarios, profesionales e intelectuales y el peronismo ha estado hegemónicamente representada por aquellos trabajos que identifican al mundo universitario, de círculos y revistas culturales y ligados a la cuestión educativa local o a la cultura de elites en tiempos del peronismo, como un bloque homogéneo, cuya identidad colectiva (en gran medida construida con posteridad desde la historiografía) se constituye precisamente a partir de considerar al peronismo como un movimiento de sesgos fascistas y particularmente antiintelectualista.

Según Terán, Altamirano y Sigal (entre otros) los escritores y artistas opositores se establecieron en ámbitos de resistencia y producción cultural. ${ }^{331}$ En ese contexto podría considerarse que ciertas publicaciones como Imago Mundi, Realidad, o Ver y estimar fueron resultado de esos espacios. Por otro lado, el Colegio Libre de Estudios Superiores y el Instituto Libre de Segunda Enseñanza siguieron funcionando, en dicho período, como espacios culturales y de educación alternativos. ${ }^{332}$ Del mismo modo, ciertas editoriales y librerías funcionaron como "refugio" para los intelectuales antiperonistas. En un mismo sentido, Flavia Fiorucci afirma que "el alejamiento de la vida intelectual y cultural de la tutela del

\footnotetext{
${ }^{330}$ Ginzburg, Carlo (2010). "Microhistoria: dos o tres cosas que sé de ella", en El hilo y las huellas, Buenos Aires, FCE.

${ }^{331}$ Terán, O. (2008). Historia de las ideas en Argentina. Diez lecciones iniciales. Buenos Aires, Siglos XXI. Sarlo, Beatriz y Altamirano, Carlos (2001). La batalla de las ideas:(1943-1973), Buenos Aires, Ariel. Sigal, Silvia (2002) "Intelectuales y peronismo", en Torre, Juan Carlos (director). Nueva Historia Argentina. Tomo VIII: Los años peronistas (1943-1955). Buenos Aires, Sudamericana.

${ }^{332}$ Sobre este tema, remitimos al trabajo de Graciano, Osvaldo (2008). Entre la torre de marfil y el compromiso político: intelectuales de izquierda en la Argentina, 1918-1955. Universidad Nacional de Quilmes Editorial.
} 
Estado significó que los intelectuales se aglutinaron en otros ámbitos". ${ }^{333}$

Espacios como los que se desarrollaron en torno a la Sociedad Argentina de Escritores (SADE) y luego la AEA, así como también las publicaciones sostenidas por la intelectualidad antiperonista como Expresión, Realidad, Liberalis, Imago Mundi y Contorno darían cuenta de esa privatización o alejamiento de los intelectuales antiperonistas no solo del espacio público, sino también de la política. $^{334}$

En otra dirección y, en relación a los ámbitos científicos, Diego Hurtado ha aportado interesantes investigaciones en torno a este mismo proceso, y ha identificado allí algunas cuestiones similares a las que hemos descripto a partir de los aportes de Fiorucci, ratificando la imagen de la "privatización" de las sociedades e instituciones científicas. Según el autor,

“(...) fuera del ámbito oficialista, algunos sectores de la comunidad cientifica, como los representados por la Asociación Física Argentina (AFA) y la Asociación Argentina para el Progreso de las Ciencias $(A A P C)$, vieron una alternativa a su situación de aislamiento en la creación de una universidad 'cientifica' privada financiada por filántropos locales, objetivo que finalmente no fue concretado". 335

La figura de Bernardo Houssay, médico argentino y premio Nobel en 1947, fue ejemplo para la prensa y las sociedades científicas internacionales de la persecución que el peronismo ejercía sobre los hombres de ciencia y la comunidad académica. También fue uno de los impulsores de espacios de investigación al margen del Estado, como por ejemplo el Instituto de Biología y Medicina Experimental en el año 1944. Su oposición al peronismo ha sido interpretada con una batalla por la independencia de las ciencias y la no intervención de la política en su desarrollo; más bien alejada de cuestiones partidarias o ideológicas. ${ }^{336}$

\footnotetext{
333 Fiorucci, Flavia (2001). "El antiperonismo intelectual: de la guerra ideológica a la guerra espiritual”, en XXIII Congreso Internacional de la Latin American Studies Association.

${ }^{334}$ Fiorucci, Flavia (2011). Intelectuales y peronismo: 1945-1955. Editorial Biblos.

335 Hurtado de Mendoza, Diego y Busala, A. (2006). "De la "movilización industrial” a la "Argentina científica": La organización de la ciencia durante el peronismo (1946-1955)". Revista da SBHC, Río de Janeiro, 4(1), 17-33.

336 Ibídem, También Hurtado de Mendoza, Diego y Fernández, María José (2013). “Institutos privados de investigación "pura" versus políticas públicas de ciencia y tecnología en la Argentina
} 
Aunque sin detenernos en sus aportes específicos, consideramos que el efecto de generalización -producido por la direccionalidad coincidente en los estudios enumerados anteriormente-, ha impedido visibilizar la existencia de otros grupos de intelectuales y científicos; especialmente aquellos que no abandonaron sus prácticas políticas ligadas orgánicamente a los partidos políticos o de las organizaciones de izquierda. En ese sentido, podemos ver cómo los trabajos de Fiorucci focalizan en aquellos colectivos cuya característica es la heterogeneidad política, pero antiperonista en general. Detengámonos, entonces, en aquellos autores que han precisado la filiación política de los intelectuales analizados.

En ese sentido, podemos señalar que tanto Adriana Petra y como Ricardo Pasolini han profundizado, precisamente, en las particulares experiencias y discursos de los intelectuales comunistas y su actividad cultural en tiempos del peronismo. ${ }^{337}$ Como rasgo principal han establecido la coincidencia primaria con la intelectualidad liberal a partir de un común antiperonismo. ${ }^{338}$ Incluso, Passolini incluye a los colectivos editoriales (como el semanario El Patriota y la revista mensual Latitud, entre otras) y partidarios comunistas dentro del grupo de la intelectualidad antifascista que, organizados frente al fenómeno fascista europeo, encuentran nuevamente puntos de unidad y necesidad de solidaridad frente al nuevo escenario planteado por el peronismo. Es decir, según Pasolini, el comunismo forma parte de esa intelectualidad liberal que se opone al peronismo al reivindicar a los revolucionarios de Mayo como padres de la república. En relación a Latitud, publicación aparecida en 1945, Pasolini observa que

\section{“(...) se utilizó la adhesión a la lucha antifascista mediante la celebración, por un lado, de los escritores europeos que aparecían como lo más granado de ese combate, sobre todo Romain Rolland y}

(1943-1955)", en Asclepio, 65 (1). Hurtado de Mendoza, Diego y Busala, A. (2002). Los ideales de universidad" científica," 1931-1959: elitismo y función social de la ciencia en la Argentina. Libros del Rojas, Universidad de Buenos Aires.

${ }^{337}$ Sin embargo, según Petra, esto no deja de tener sus matices. Como lo demuestra en su tesis doctoral, se observa cierto acercamiento a la prédica nacionalista del peronismo y que los separa momentáneamente de la familia liberal. Petra, Adriana Carmen (2013) Intelectuales comunistas en la Argentina (1945-1963) (Tesis de posgrado). Presentada en Universidad Nacional de La Plata. Facultad de Humanidades y Ciencias de la Educación para optar al grado de Doctora en Historia.

${ }^{338}$ Petra, Adriana (2010) "Cosmopolitismo y nación. Los intelectuales comunistas argentinos en tiempos de la Guerra Fría (1947-1956)" en Contemporánea. Historia y problemas del siglo XX, Volumen 1, Año 1. Pasolini, Ricardo (2013). Los marxistas liberales. Antifascismo y cultura comunista en la Argentina del siglo XX. Buenos Aires, Sudamericana 
Louis Aragón. Mientras que por otro lado, se reconoció en el pasado liberal argentino la matriz de la verdadera tradición política en la que debian reconocerse (...). En la edición de junio de 1945, Latitud sintetizó con una serie de ilustraciones hasta dónde llegaban los límites de esa tradición. En la tapa y contratapa del censuario publicó los retratos de Moreno, Rivadavia, Monteagudo, Echeverría, Sarmiento, Avellaneda, Alberdi, Mitre, Mármol, Wilde, Ramos Mejía, Juan B. justo, Ingenieros, Joaquín V. González, Alejandro Korn, Lisandro de la Torre y Aníbal Ponce”. 339

Aún más cercanos al espectro del liberalismo, se ubican los socialistas. Uno de los aportes sobre los intelectuales de ese partido es producido por Carlos Herrera, quien describe las diferentes interpretaciones que Américo Ghioldi, principal referente en esos tiempos, elabora sobre el peronismo. Con fluctuaciones según el momento y tomando como fuente las editoriales de La Vanguardia y algunos escritos políticos del militante, puede verse que las mencionadas interpretaciones varían entre la calificación del peronismo como un totalitarismo a su descripción como un movimiento que realiza reformas obreristas revolucionarias desde el Estado. ${ }^{340}$ A su vez, Martínez Mazzola toma posición desde "la voz de los actores" en tanto describe los debates y enfrentamientos entre el ala liberal reformista del socialismo (encabezada por Ghioldi) y el obrerista o revolucionario liderado según el autor por Julio V. González a partir del triunfo electoral de Juan D. Perón. ${ }^{341}$

Por último, y en relación a la actividad política, y la participación en espacios académicos e intelectuales de los socialistas, Osvaldo Graciano identifica

\footnotetext{
339 Pasolini, Ricardo (2013). Los marxistas liberales. Antifascismo y cultura comunista en la Argentina del siglo XX. Buenos Aire, Sudamericana. Pág. 127-128

${ }^{340}$ Herrera, Carlos Miguel (2005). ¿La hipótesis de Ghioldi? El socialismo y la caracterización del peronismo (1943-1956)", en H. Camarero y C. Herrera (comps.), El Partido Socialista en la Argentina.Sociedad, política e ideas a través de un siglo, Buenos Aires, Prometeo.

341 Martínez Mazzola, Ricardo (2011). "Nacionalismo, peronismo, comunismo. Los usos del totalitarismo en el discurso del Partido Socialista Argentino (1946-1953)", en Prismas. Re vista de historia intelectual. vol.15 no.1 Bernal ene. / jun. 2011. Otros trabajos sobre los debates en el socialismo, García Sebastiani, Marcela (2005). Los antiperonistas en la argentina peronista 19451951, Buenos Aires, Prometeo Libros; Herrera, Carlos (2003) "El Partido Socialista ante el peronismo, 1950. El debate Ghioldi-González", Taller. Revista de sociedad, cultura y política, Buenos Aires, $\mathrm{N}^{\circ} 21$, pp. 116-141.
} 
y describe un intenso movimiento en torno a la ciudad de La Plata y de su universidad. Embanderados tras los ideales de la Reforma universitaria de 1918, socialistas y anarquistas ligados a las estructuras partidarias e institucionales de la universidad, convergieron en tiempos del peronismo en actividades culturales con posterioridad a ser expulsados, exonerados o haber renunciado a sus cargos docentes y de investigación. Alfredo Palacios, Guillermo Korn, Pedro Verde Tello, Carlos Sánchez Viamonte, Julio V. González entre los socialistas y Aquiles Martínez Civelli, Rafael Grinfeld, Carlos Bianchi, José María Lunazzi entre los anarquistas, representan el grupo de universitarios e intelectuales que en tiempos del peronismo, actúan muchas veces en solidaridad en actividades organizadas por la Casa del Pueblo, la Unión Socialista Libertaria de La Plata o en el Centro de Graduados de la UNLP. ${ }^{342}$ Por primera vez desde la historiografía, Graciano describe las trayectorias laborales e intelectuales de este grupo de universitarios que, sosteniendo el ideario libertario con anterioridad a su ingreso a la institución, renuevan y reformulan sus estrategias de acción política en relación a las reformas implementadas por el gobierno peronista en el ámbito educativo. ${ }^{343}$ Sin embargo, las especificidades de las apelaciones libertarias, el devenir en sus organizaciones y las estrechas relaciones establecidas por estos universitarios entre sus prácticas profesionales y su militancia política, aún no han sido abordadas en profundidad.

Por fuera del marco estricto de los partidos de izquierda, se encuentra, por otro lado, el movimiento estudiantil, que ha sido representado desde la historiografía como uno de los sujetos que más abiertamente y de manera más directa se opuso y realizó acciones contra el gobierno peronista. Las disposiciones estatales fueron interpretadas por el movimiento estudiantil como parte de las políticas universitarias de avasallamiento que influían negativamente en la

\footnotetext{
342 Acerca de la figura de Rafael Grinfeld, resultan iluminadores sobre los aspectos personales y profesionales, los trabajos de Rocca, Carlos (1983) El Dr. Rafael Grinfeld o el precio de investigación científica en la Argentina, Eds. Geocart S.A., Buenos Aires y Bibiloni, A.G. (2007). "La Física en La Plata, del justicialismo al desarrollismo pasando por "la Libertadora", en http://anales.fisica.org.ar/journal/index.php/analesafa/article/viewFile/214/235

343 Sobre el peronismo y la política educativa, ver Carli, Sandra (1998). "Infancia, política y educación en el peronismo: de los derechos del niño a las vanguardias políticas del futuro.” Anuario de historia a de la educación, $\mathrm{N}^{\circ} 2$. Ciria, Alberto. (1983). Política y cultura popular: la Argentina peronista, 1946-1955. Buenos Aires, Ediciones de la Flor. Cucuzza (1996). Historia de la Educación en debate; Bs. As. Miño y Dávila. Puiggros, Adriana (Dir.) (1995). Discursos Pedagógicos e imaginario social en el peronismo (1945-1955), Buenos Aires, Galerna.
} 
"independencia" de los claustros, expulsando con ellas los ideales de la reforma de 1918 cuya bandera era enarbolada aún por la mayoría de los docentes y estudiantes de las 6 universidades nacionales existentes en ese momento. La Federación Universitaria (FUA), Federación Universitaria de Buenos Aires (FUBA) y diversos centros de estudiantes como el de la Facultad de Derecho de la UBA o de la Facultad de Ingeniería de la UNLP son ejemplo de compromiso político y actividad organizativa en los tiempos de los primeros gobiernos peronistas. ${ }^{344}$ De todos modos, esta bibliografía también denota, como lo hemos descripto en la introducción de este trabajo con respecto a determinadas lecturas "desde adentro", un halo de heroicidad y misticismo, que en general oprime las diversas identidades e identificaciones que los sostenedores del movimiento estudiantil seguramente contenían. Es decir, el "antiperonismo" académico (nuevamente) cubre con su manto de homogeneidad, la heterogénea experiencia de la activación estudiantil.

Entonces, hemos referido el tratamiento que gran parte de la historiografía ha producido sobre tres sujetos que, en tiempos de apelación a sectores no solamente obreros, el anarquismo vislumbraba como posibles hermanos en la lucha y resistencia al peronismo: los profesores universitarios ligados a los ámbitos de la intelectualidad progresista y de izquierda, los científicos y los estudiantes. En el presente capítulo, intentaremos avanzar sobre las descripciones, interpretaciones y acciones que llevaron a cabo los colectivos libertarios para analizar, interpelar y enrolar a estos tres sujetos (masculinos) en la lucha por "la idea" en tiempos del "fascismo criollo".

\section{De la Unión Democrática a la pulverización de las alianzas}

En el contexto preelectoral de 1946, la Unión Cívica Radical, el Partido Demócrata Progresista, el Socialista y el Comunista apostaron por la vía

\footnotetext{
${ }^{344}$ Sobre la historia de la FUA, el movimiento estudiantil y su participación en los años de nuestro estudio, remitimos a los trabajos de Almaraz, Roberto; Corchon, Manuel y Zemborain, Rómulo (2001) ¡Aquí FUBA! Las luchas estudiantiles en tiempos de Perón (1943-1955). Buenos Aires, Planeta. Berdichevsky, L; Inglese, J.; Yegros Doria, C. (1965). Universidad y estudiantes. Universidad y peronismo. Buenos Aires, Libera
} 
eleccionaria para disputar la instalación del peronismo en el Estado, como movimiento político y como partido de masas.

No obstante, en conjunto, las figuras del anarquismo que hemos visibilizado se definieron en contra de una salida electoral cuando todo el arco de los universitarios opositores al peronismo optó por el apoyo a la Unión Democrática. Ésta no fue una decisión unívoca. En sus memorias, José Grunfeld habla de sus desencuentros con José Lunazzi por este tema. Grunfeld refiere que Lunazzi fue uno de los pocos anarquistas que pensó en formar parte de la Unión Democrática como medio para enfrentarse al peronismo-fascismo que se acercaba al poder por medio de las urnas. ${ }^{345}$

El embanderamiento de la Unión Democrática como oposición política al peronismo bajo el mote de "defensores de la democracia", llevó a esta coalición a colocar al naciente movimiento multisectorial de apoyo a Juan Domingo Perón en las antípodas. El peronismo será para ellos sinónimo de "autoritarismo". Sin duda, las divergencias en cuanto a las nociones acerca de la "democracia" posible, empuja a aquellos que, de la mano del anarquismo, están pensando en una vertiente "radical" de la misma: no estatal, con base asamblearia, federativa y horizontal; fundamentalmente alejada de los programas políticos que la piensan como una posibilidad dentro de la puja política por el Estado. ${ }^{346}$ Según Reconstruir el triunfo de Perón en las elecciones de febrero no sólo tuvo su base en la demagogia y en una campaña que se sustentó en promesas de mejoras sociales para sectores muy postergados. La responsabilidad del fracaso de la Unión Democrática recae precisamente sobre sus propias bases. Advierten un error de cáculo en cuanto a suponer que obtendrían votos de los sectores populares que habían apoyado al irigoyenismo, o sea, radicales:

\footnotetext{
345 Grunfeld, José (2004). Memorias..., op. cit. Sobre la Unión Democrática, remitimos a los trabajos de Bisso, A. (2002). "De Acción Argentina a la Unión Democrática", en Prismas. Revista de historia intelectual, (6), 257-264. Bisso, Andrés (2005). Acción Argentina: un antifascismo nacional en tiempos de Guerra Nacional: Acción Argentina y las estrategias de movilización del antifascismo liberal-socialista en torno a la Segunda Guerra Mundial (1940-1946). Prometeo Libros. Sebastiani, Marcela (2005). Los antiperonistas en la Argentina peronista: radicales y socialistas en la política argentina entre 1943 y 1951. Prometeo Libros.

${ }^{346}$ En el desarrollo del presente capítulo desplegaremos las propuestas de organizaciones federativas ideadas fundamentalmente por los referentes del movimiento libertario Juan Lazarte y José Lunnazzi. Ambos han dedicado gran parte de su trayectoria a pensar y proponer diversas posibilidades de organización con bases federativas.
} 
"Hubo excesiva confianza en una mayoría que las cifras del escrutinio no confirmaron, No se comprendió que los tiempos habían cambiado y se reeditaron las antiguas tácticas electoralistas. El mito de la mayoría radical fincaba a su vez en otro mito: el de Irigoyen, sin advertir que el adversario no tendría el menor escrúpulo de apropiarse de él". 347

Pareciera estar presente aquí la idea de "masas disponibles", pero diferente al sentido germaniano del término. Más bien, los sectores populares que votan al peronismo, no solamente han perdido la identidad política que los ligaba al radicalismo, sino que una situación prolongada de miseria y de regimenes fraudulentos los inclina a creer en un personaje que demuestra sensibilidades sociales y parece contar con los recursos económicos necesarios para transformar la vida de cada uno de ellos. ${ }^{348}$ Según Reconstruir, el triunfo de Perón también fue consecuencia de optar por una salida electoral, de haber creído en la legitimidad del proceso eleccionario, frente a un fenómeno que se adivina

"fascista":

“El peronismo triunfó además porque no hubo desobediencia civil, porque no se apoyó a los estudiantes cuando tomaron las universidades; porque se especuló demasiado cuando prácticamente no había gobierno, antes del 17 de octubre; porque no se organizó la lucha contra él considerándolo fascismo, sino como adversario electoral". 349

A partir de esta cita, se comprenden las diferencias que los anarquistas identifican con respecto a la Unión Democrática y su no participación en esta última. Según Reconstruir, el análisis del escenario político sobre el que la U.D. elabora su propuesta, es erróneo. Sin embargo, el anarquismo enfrentará y

\footnotetext{
347 “Por qué ha triunfado el peronismo”, Reconstruir, No 1, Junio de 1946. Pág. 2.

348 "Vastos sectores del pueblo, pertenecientes a las capas más humildes, más explotadas y obligadas a vivir con la mayor indigencia, habian esperado en vano, durante lustros, que las promesas de unos y otros candidatos se convirtieran en realidad una vez en el poder. Y de repente se encontraron con el hombre que, desde el gobierno, realizaba actos efectistas en su beneficio: rebajas de alquileres, aumentos de sueldos (...)"."Por qué ha triunfado el peronismo", Reconstruir, $\mathrm{N}^{\circ} 1$, Junio de 1946. Pág. 2.

${ }^{349}$ Ibídem, 
reelaborará sus repertorios de acción frente a esta nueva situación generada a partir del triunfo electoral de Perón. Como veremos, en la búsqueda de los "aliados", el anarquismo desplegará diversas estrategias dependiendo de las temáticascontroversias desplegadas con el fin de interpelar al peronismo (como actornegativo pero necesario) y sumar adeptos a la causa universitaria, intelectual y educativa. En este momento, resulta de fundamental importancia identificar los actores a los que los colectivos libertarios interpelan en las publicaciones aquí citadas y bajo el tópico de "preservar la autonomía" universitaria y de la educación en general. Damos por descontado que estas publicaciones intentan llegar a públicos diferenciados: Acción Libertaria piensa en un lector comprometido con las causas libertarias, con participación o intereses ligados al ámbito educativo (léase maestros, escritores o estudiantes), pero fundamentalmente con participación orgánica en de la Federación Anarco Comunista de la Argentina. ${ }^{350}$ Por otro lado, Reconstruir identifica a su público con aquellos sectores que, con experiencia universitaria o en círculos intelectuales y culturales ligados al humanismo y al laicismo, pueden sumar desde perspectivas diversas a la lucha contra el peronismo y sus proyectos aplicados al ámbito de la cultura en general. ${ }^{351}$ Por último, la Revista Americana de Educación (RAE) propone discutir las formas de la organización de la educación en general, sin una perspectiva o ideología política definidamente libertaria, pero con énfasis en la agremiación y la lucha docente, reivindicando el rol de los educadores como mojones de democracia y faros de cultura frente al avasallamiento de una educación dirigida y clerical.

El triunfo de Juan Domingo Perón en las elecciones de febrero de 1946, conlleva una nueva intervención de las universidades nacionales. Ello afectó a un amplio espectro político de universitarios y profesionales en sus fuentes laborales. ${ }^{352}$ Una vez concluido el período de intervención, el gobierno peronista reglamenta una nueva Ley para las Universidades Nacionales, la 13. 031, que comienza a implementarse en el año 1947. Sin embargo, la mayoría de las

\footnotetext{
${ }^{350}$ A.L., $\mathrm{N}^{\mathrm{o}} 115,1947$

${ }^{351}$ Reconstruir, $\mathrm{N}^{\mathrm{o}} 1$, Junio de 1946. Tapa.

352 Soprano, Germán (2009). "Política, instituciones y trayectorias académicas en la universidad argentina. Antropólogos y antropología en la Universidad Nacional de La Plata entre las décadas de 1930 y 1960", en Marquina, Mónica; Mazzola, Carlos y Soprano, Germán (comp.) Políticas, instituciones y protagonistas de la universidad argentina. Prometeo, Universidad Nacional de San Luis.
} 
investigaciones resalta que es precisamente durante la intervención del gobierno cuando se produce el recambio "obligatorio" en los claustros docentes y los centros de investigación en la mayoría de las universidades. Según Soprano,

“(...) la nueva política universitaria del Estado nacional se impuso autoritariamente sobre las Universidades. Entre 1946 y 1947 la oposición reformista fue confrontada a nivel nacional por medio de cesantías de 423 docentes, al tiempo que se generaron las condiciones para que otros 823 renunciaran voluntariamente o en solidaridad con los primeros, oponiéndose a la limitación de funciones en las tareas de docencia e investigación y/o como crítica al violento recorte de la autonomía universitaria". 353

En el caso de los universitarios libertarios que fueron protagonistas en el período inmediatamente anterior en distintos puestos de relevancia académica y de gestión universitaria, todos fueron expulsados durante esta nueva intervención. Carlos Bianchi fue cesanteado de su cargo en la materia Máquinas Eléctricas en la Facultad de Ingeniería. Rafael Grinfeld lo es de su cargo como director del Instituto de Física de la UNLP y del cargo en la materia Física. José María Lunazzi queda cesante de la cátedra Investigaciones Pedagógicas de la Facultad de Humanidades, del mismo modo que Martínez Civelli es cesanteado de la cátedra Maquinarias Eléctricas en la Facultad de Ingeniería. La situación política y sus convicciones significarán para algunos de ellos su postergación profesional. Por caso, vale de ejemplo lo sucedido a Lunazzi. En la introducción de su tesis doctoral titulada "Finalidad, objetivo e ideal educativo. 1946-1986" (defendida en año 1986), José María Lunnazi refiere que en el año 1946 retira de evaluación su tesis doctoral ("Finalidad e ideales educativos", dirigida por Alfredo Calcagno), como gesto de solidaridad con el movimiento estudiantil. En los meses posteriores, es dejado cesante de su cargo. ${ }^{354}$

El triunfo de Perón representó para la FACA la implantación definitiva del fascismo en el país, pero ya no como fenómeno aislado sostenido por un grupo de militares aduladores del clero -como habían evaluado al gobierno anterior-, sino

\footnotetext{
${ }^{353}$ Ibídem,

${ }^{354}$ Graciano, Osvaldo (2008). Entre la torre..., op. cit. 
con un fuerte anclaje y aprobación popular. ${ }^{355}$ Sobre este reconocimiento del anclaje popular del peronismo, el colectivo libertario pensará la clave para las nuevas estrategias organizativas y los proyectos culturales. Son precisamente esos "otros ámbitos" en los que apreciamos los repertorios organizacionales, editoriales y de acción colectiva entre los libertarios.

En este caso, debemos diferenciar tres tipos de "repertorios", partiendo de considerar las individualidades y particularidades de los/las anarquistas que sostienen en estos años las agencias libertarias.

En primer lugar, encontramos aquellos que orgánicamente responden a FACA, cuyo mensaje se alinea claramente con los ideales libertarios y cuyos discursos están dirigidos a un público ligado a una cultura política de izquierdas y de tradición antifascista. Son los casos de Reconstruir, Acción Libertaria y las USL.

En segundo lugar, identificamos y agrupamos a aquellas publicaciones y repertorios organizacionales que, aunque impulsadas y sostenidas por militantes referentes del socialismo libertario y del mundo universitario, su leit motiv es la defensa del "reformismo" en la universidad. ${ }^{356}$ Encontramos en este segundo grupo a la Revista Americana de Educación (R.A.E.), la Federación de Agrupaciones para la Defensa y Progreso de la universidad Democrática y Autónoma y la

Alianza Laica Argentina (A.L.A.), la Universidad Libre de Buenos Aires y La Plata.

En tercer lugar, ubicamos a los grupos, movimientos y organizaciones que con una historia previa a la llegada del peronismo y alejadas del ideario libertario, comienzan a partir de este momento a ser impulsadas y defendidas por los anarquistas por el solo hecho de manifestar su oposición a las políticas educativas implementadas por el gobierno peronista. El motivo de este apoyo será simplemente

\footnotetext{
${ }^{355}$ Como bien lo ha analizado Fiorucci, los círculos culturales e intelectuales (en su mayoría de izquierda pero también liberales), vieron el triunfo electoral de Juan Domingo Perón como el momento de la instauración del fascismo en Argentina. Fiorucci, Flavia (2004) "iAliados o enemigos? Los intelectuales en los gobiernos de Vargas y Perón". Estudios Interdisciplinarios de América Latina y el Caribe, Julio - Diciembre

${ }^{356}$ Sobre los valores y las características anarquismo en relación al "reformismo" en los años 40", remitimos al capítulo 1 del presente trabajo.
} 
la actitud combativa y la militancia antiperonista. Encontramos en este grupo a la Federación Universitaria de la Argentina (FUA), la Federación Universitaria de La Plata (FULP), la Federación Universitaria de Buenos Aires (FUBA), la Asociación de Maestros y un amplio abanico de organismos ligados a la enseñanza, la cultura y la intelectualidad a lo largo y ancho de la Argentina.

Si bien esta dimensión, en cuanto a las diferencias en los repertorios que hemos enumerado, estará presente en nuestro análisis, el mismo se vertebrará en torno a dos ejes. Estos dos ejes, que metodológicamente diferenciaremos en el plano del discurso y sobre los que se desplegarán las controversias, son la clave para comprender en qué medida el anarquismo disputará sujetos con el peronismo en torno a la cuestión educativa, cultural e intelectual: por un lado, el avasallamiento de la autonomía y democracia universitaria por medio de la persecución y la enseñanza religiosa; en segundo lugar, la movilización estudiantil y las agrupaciones de científicos y docentes como forma de combatir al peronismo.

\section{Religión y Estado: el avasallamiento de la autonomía y la democracia}

"Las seis Universidades Argentinas, desde el 30 de abril se hallan bajo el régimen de intervención federal. Al tomarse esa medida ellas cumplían un año de dificultosa vida autónoma establecida por el mismo gobierno de facto luego de escabrosas intervenciones. La causal de esta última intromisión se funda en un propósito de dictar pronto una nueva ley o una ley universitaria". ${ }^{357}$

Tanto para los integrantes de las organizaciones libertarias como para todo el arco de la izquierda y de la oposición al peronismo, toda manifestación masiva o movilización política de amplios sectores sociales cambia de sentido con la llegada de Juan Domingo Perón. La masividad en las manifestaciones por el $1^{\circ}$ de mayo o el apoyo en las calles a la Huelga de inquilinos en 1907 (entre otras grandes

${ }^{357}$ R.A.E., $\mathrm{N}^{\mathrm{o}}$ 1, julio/agosto de 1946 
huelgas sucedidas en la primera década del siglo) son política e ideológicamente defendidas por el anarquismo porque el fin de las mismas es el socavamiento del orden capitalista. Según Suriano, de todas formas, el dilema entre pueblo/masa y vanguardia ha sido una constante en las concepciones y orientaciones del anarquismo no solo en la Argentina, sino que es un debate que proviene del mismo seno de la doctrina anarquista desde los años en que se gesta. ${ }^{358}$

En su estudio sobre cuál es el sujeto revolucionario para el anarquismo, focalizando en la figura de Ricardo Mella por la influencia de su pensamiento en las organizaciones locales, declara que es precisamente la acción de aquellos sujetos conscientes (no necesariamente ligados a la clase obrera) la que por sus acciones motivará la adhesión de las clases populares. En palabras de Mella,

"A la hora presente, hay más socialistas y anarquistas en la clase media modesta que en las filas del proletariado. Los obreros, en general, permanecen inconscientes de sus derechos, dormidos para las aspiraciones emancipadoras, interesados a lo más por pequeñas y discutibles ventajas de momento. Los militantes obreros del socialismo y del anarquismo son, por lo regular, gentes escogidas por su ilustración, por sus gustos, por su peculiar intelectualidad. Pero fuera de esa pequeñísima minoría, el socialismo y el anarquismo tienen el núcleo principal y más numeroso de sus adeptos en el mismo seno de la burguesía". 359

Sobre esta caracterización del anarquismo pivotearán las interpelaciones de los colectivos anarquistas a partir de 1930. A partir de allí, y en las sucesivas reinterpretaciones de esta idea, la cuestión de la "cantidad" no habría sido una dimensión necesaria para el cambio social según en los años de nuestro estudio. Estas cuestiones son de utilidad para pensar los trastoques que la llegada del peronismo genera dentro del movimiento libertario en relación con la cuestión del apoyo masivo y popular al nuevo movimiento: el apoyo de las masas al nuevo líder es ejemplo de manipulación, nada tiene que ver con una actitud conciente o racional

\footnotetext{
${ }^{358}$ Suriano, Juán (2001). Anarquistas..., op. cit.

${ }^{359}$ Mella, Ricardo (1909). "La lucha de clases", en Tribuna Libre, núm. 3. Gijón, 8 mayo. Sobre el ideario y la vida de Ricardo Mella, remitimos al trabajo de Fernández Álvare, Antón (1990). Ricardo Mella o el Anarquismo Humanista. Madrid, Editorial Anthropos.
} 
por parte de las mismas. Como veremos, establecer controversias con el peronismo, desde el plano doctrinal $\mathrm{y}$ de las concepciones políticas, tiene como fin el "movilizar" aliados, no masas.

La diferencia entre los actores a los que intentarán movilizar y las "masas incultas" que se movilizan por mera manipulación y demagogia ejercida por Juan Perón es la calidad en la composición de los primeros. La experiencia de la movilización de los universitarios durante la toma de la Universidad de La Plata en el año 1945 demostró la importancia que tenía el apoyo masivo de todos los claustros para lograr la "autonomía" del gobierno universitario para los libertarios comprometidos en el problema universitario.

Según Soprano, el período que transcurre entre las dos presidencias de Juan Perón, la universidad se rigió por las $N^{0} 13.031 / 47$ y 14297/53. De esta manera, el Poder Ejecutivo se imponía como autoridad indiscutida dentro de las universidades, al mismo tiempo que rompía con la "autonomía" lograda y sostenida por los postulados de la Reforma de 1918 vigente (con interrupciones) hasta el año 1946. Percibimos que las ideas que aparecen en los textos e investigaciones académicas no se diferencian ni se toma distancia de las denuncias y apreciaciones realizadas por los actores, en este caso los colectivos libertarios y los miembros del reformismo que al mismo tiempo sostienen las organizaciones ácratas. ${ }^{360}$

Las publicaciones analizadas evidencian posturas que se resumen en el reclamo de los postulados de la Reforma del 18, es decir, no existen apuestas novedosas en relación al contenido o las implicancias de la "autonomía" reclamada para la universidad, sino que se evidencian las continuidades discursivas respecto del período inmediato anterior como hemos visto en el capítulo 1. De esta manera, el avasallamiento a la "autonomía" de la institución universitaria por parte del gobierno peronista, será denunciada por todas las publicaciones y un reclamo

\footnotetext{
${ }^{360}$ Entre otros, apreciaciones similares encontramos en Halperín Donghi, Tulio (1962) Historia de la Universidad de Buenos Aires, Buenos Aires, Eudeba. Mangone, Carlos y Warley, Jorge (1984) Universidad y peronismo (1946-1955), Buenos Aires, Centro Editor de América Latina; Sarlo, Beatriz (2001). La batalla de las ideas, Buenos Aires, Editorial Ariel. Argumentos similares hallamos en las descripciones de O. Graciano sobre el Colegio Libre de Estudios Superiores. Graciano, Osvaldo (2008). Entre la torre..., op. cit.
} 
común a los colectivos que analizamos. La nueva Ley Universitaria (13031/47), aprobada y reglamentada en el año 1947, impide la participación de los estudiantes en los organismos de gobierno universitario. La batalla de los anarquistas, a favor de la autonomía, retomará precisamente la denuncia de esta expulsión. ${ }^{361}$ Precisamente, porque las esperanzas del movimiento libertario con respecto al movimiento reformista, está puesta en "los estudiantes" y las fuerzas juveniles como grupo históricamente revolucionarios:

\section{"Llamamos particularmente a las fuerzas juveniles para que se sitúen en este momento del mundo. Frente a nosotros todavía perdura un pasado de errores e ignominia: siglos de oscurantismo y de terreno imperio clerical (...); sirviendo (como en Argentina) a la persecución de la escuela laica y del pensamiento libre y al propio afianzamiento dictatorial". 362}

Es decir, no pueden imaginar la posibilidad de una sociedad autónomamente organizada sin la vitalidad de la juventud. En relación al proceso de movilización de los universitarios y la instauración de los principios de Reforma Universitaria a partir de 1918, Lazarte destacaba en una nota sobre la juventud universitaria argentina, que a pesar de los defectos que la reacción podía adjudicarle, fue más revolucionaria que el profesorado y mejor que los políticos que mandaron en la universidad y en el gobierno. Sin embargo, a pesar de no haber sido totalmente revolucionaria, afirma que la juventud estudiosa tampoco era conservadora. ${ }^{363}$

De todas formas, creemos necesario diferenciar dos momentos en las denuncias de los colectivos libertarios acerca del atropello a la autonomía universitaria por parte del Estado peronista. Un primer momento refiere al de la intervención de todas las universidades nacionales (desde abril de 1946). Frente a esta situación, la denuncia sobre el comienzo del fin de las libertades individuales tiene su máximo ejemplo en la intervención de las universidades nacionales. Según

\footnotetext{
361 "Normalización universitaria", A. L., $\left.\mathrm{N}^{\mathrm{o}} 115,1947\right)$

${ }^{362}$ U.S.L. de Buenos Aires (1946). Declaración de principios. s/d.

${ }^{363}$ Lazarte, Juan (1935). Líneas y trayectorias de la Reforma Universitaria. Rosario, Editorial Ruiz.
} 
Reconstruir, estas acciones representan el primero de una serie de "posibles" de intervenciones a instituciones educativas y culturales que hasta el momento, y con períodos interrumpidos, habían logrado cierta autonomía con respecto al control estatal. ${ }^{364}$ Un segundo momento comienza con la promulgación de la ley 13031 en octubre de 1947 a partir de la cual se reglamenta un nuevo régimen universitario. El problema, según la prensa libertaria, reside ahora en las disposiciones de la nueva ley y la impronta de control ideológico que ésta contiene, puntualizando en la exclusión de los estudiantes en las instancias de decisión institucional y reemplazando a docentes, investigadores e institutos por personas ligadas a los sectores conservadores, católicos y hasta ese momento alejados del ambiente universitario. De este modo, las alocuciones con respecto a estos dos escenarios presentan sensibles diferencias.

Sin duda, los proyectos periodísticos, culturales y educativos que hemos enumerado anteriormente, corresponden a la reformulación del movimiento libertario frente a la aparición del peronismo como fenómeno de masas y al triunfo de Juan Perón en las elecciones de febrero de 1946, cuestión abordada en los capítulos anteriores. Durante este primer año de intervención a las universidades (ordenada por el saliente Farrell antes de entregarle la presidencia a Perón) ambas publicaciones dan cuenta del avasallamiento, por vías no democráticas, de la vida universitaria. Reconstruir no ve diferencias entre esta nueva intervención y las sucedidas a partir del año 1943. En relación a la Universidad del Litoral, el periódico establece una permanencia de los sectores católicos y nacionalistas incluso en el nuevo escenario. ${ }^{365}$ Estos mismos elementos "reaccionarios" son los que aparecen relacionados con el grupo de militares que lleva adelante el golpe de Estado del año 1943, hermanados con el nacionalismo católico. ${ }^{366}$

\footnotetext{
${ }^{364}$ Reconstruir, № 1, Junio de 1946. Pág. 6

${ }^{365}$ La genealogía de los Rectores/interventores de la UNL durante todo el período del gobierno peronista, da cuenta de estos vínculos. 1946-Miguel Mordeglia, Rector Interventor; 1946-1947: Julio A. Tezanos Pintos, Rector Interventor; 1947-1948: Edgardo María Ilaire Chaneton, Rector Interventor; 1948-1950: Ángel Francisco Guido, Rector nombrado por el Poder Ejecutivo Nacional, 1950-1951; Carlos Julián Ferreira, Rector Interventor, 1951-1952; Bernardo Juan Guilhé, Rector Interventor 1952-1955; Raúl Rapella, Rector designado por el Poder Ejecutivo Nacional

${ }^{366}$ Reconstruir, $\mathrm{N}^{\mathrm{o}} 2$, julio1946.Sobre la relación entre nacionalismo, catolicismo y peronismo, remitimos a los trabajos Caimari, Lila (1995). Perón y la Iglesia Católica: religión, estado y sociedad en la Argentina, 1943-1955. Ariel, Buenos Aires. También Zanatta, Loris (1996). Del estado liberal a la nación católica. Universidad nacional de Quilmes.
} 
En relación a la Universidad Nacional de La Plata, el panorama es similar. Según Reconstruir, al mismo atropello intervencionista, se le suma la creación de grupos estudiantiles que apoyan la acción de los interventores, es el caso de la Federación Universitaria Revolucionaria, proveniente de los sectores católicos juveniles. ${ }^{367}$ Según la Agrupación Estudiantil Anarquista, relacionada con la

FORA y no directamente con las agrupaciones como FACA o las USL, el "Plan Figuerola" (es uno de los 28 proyectos de ley que componen el primer plan quinquenal) para la universidad tiene como fin convertirla en un feudo del presidente, en el que se prohíbe la opinión política, los decanos y rectores son electos por el presidente y los docentes pueden ser desplazados de sus cargos según criterio del decano, rector o del mismísimo presidente. Del mismo modo, según la agrupación mencionada, la obligatoriedad en la asistencia para los alumnos no hará más que limitar el acceso de aquellos jóvenes que no puedan dejar sus obligaciones laborales ni familiares con el fin de formarse limitando la institución a un espacio de formación para la oligarquía.. ${ }^{368}$ Se destaca aquí el modo en que prevalecen algunos reclamos históricos de la FORA como son la preponderancia del obrero como eje vertebrador de la lucha contra el capital y la opresión. Pero también resulta interesante la manera en que se alejan del "reformismo" en la universidad, en cuanto a que ellos tampoco representan al pueblo obrero y no proponen ningún programa superador con respecto al de la universidad peronista:

“En tiempos no tan lejanos, las personas que deseaban consagrarse por vocación o cálculo de probabilidades, al profesorado universitario o secundario, debían reunir ciertas condiciones técnicas y, por lo general, para llegar a ser a la cátedra, ser convenientemente recomendadas por alguna figura influyente. Esa es

\footnotetext{
${ }^{367}$ Reconstruir, $\mathrm{N}^{\mathrm{o}} 5$, agosto de 1946.

${ }^{368}$ Según esta agrupación, en el "Plan Figuerola", "Se anatemiza la universidad oligárquica, pero a continuación se establece la concurrencia obligatoria a las clases, con lo que indudablemente no se favorece la incorporación a la educación superior de los jóvenes que deben ganar su pan o el de su familia". De Pie! Órgano de la Agrupación Estudiantil Anarquista. Noviembre de 1946. Según esta publicación, el Centro de Estudiantes de Derecho de la UBA tenía filiaciones ideológicas en sintonía con las de la FORA, a pesar de que su presidente hubiera tenido participación en el radicalismo. A la actualidad no existen trabajos al respecto. Posiblemente sean los primeros esbozos de la actividad universitaria hermanada con la activación obrera en la Argentina, tema altamente transitado para el período que sucede a la caída del peronismo, por ejemplo en los trabajos de Ana Barletta. Barletta, Ana (2002). "Una izquierda universitaria peronista. Entre la demanda académica y la demanda política (1968-1973)”, en Prismas. Revista de Historia Intelectual, 6, 275-286.
} 
la verdad, digan lo que quieran los defensores a ultranza de la universidad "tal como estaba antes. Pero al menos el recomendado quedaba libre posteriormente, de ataduras oficiales, pudiendo incluso, murmurar y militar políticamente en la oposición. Nadie lo tomaba del cuello para arrojarlo a la calle si opinaba distinto al señor Castillo, por ejemplo", 369

Para ese colectivo estudiantil la Universidad tal como estaba antes, resultaba de todos modos un espacio que presentaba dificultades para el acceso de aquellos sectores provenientes del mundo de los trabajadores o sin relación con el mundillo universitario e intelectual. La crítica a la "nueva universidad" no incluye la problemática de clase, en cuanto a si la consideran aún un espacio exclusivo de la burguesía, puesto que según este artículo, sólo sería necesario para acceder a ella, una actitud pasiva y de adulación al nuevo gobierno.

"Ahora se exige, nada menos, ser ciego, sordo y sobre todo mudo, y además disponen de un largo y gracioso rabo que se incline reverente ante cada gesto presidencial. El gobierno barre con escoba de hierro la parte más consciente o menos inconsciente del profesorado. La enseñanza deberá ser ejercida por un cuerpo disciplinado de calabazas huecas ;Callarse y obedecer! Pronto dictarán cátedra los sargentos y cabos del ejército y la policía”. ${ }^{370}$

Como se expone en este fragmento citado, las apreciaciones del movimiento estudiantil ligado al anarquismo divergen de aquellas que hemos observado en docentes como Lunazzi o Grinfeld, fundamentalmente en cuanto al análisis de la universidad como institución de la burguesía. De todas formas, las agencias de los colectivos estudiantiles enrolados con el movimiento anarquista serán abordadas más adelante en el presente capítulo. Pretendemos con esta cita dar cuenta de la diversidad de opiniones y apuestas dentro de aquellos/ as embanderados en el anarquismo.

\footnotetext{
${ }^{369}$ De Pie! Órgano de la Agrupación Estudiantil Anarquista. Noviembre de 1946. Pág. 2.

${ }^{370}$ Ibídem,
} 
Volviendo a la descripción de la situación, según Reconstruir, la aparición de nuevos actores políticos en la universidad es acompañada también por

"sobornos" a alumnos, profesores y trabajadores que no acompañan la nueva administración:

“A los alumnos, profesores y empleados dignos echados sin más razón que la de su indeclinable decencia. Y ahora, el soborno con los que quedan. Ya se habla de duplicar sueldos, de llevar el presupuesto de la Universidad a una cifra impresionante y de nuevas creaciones de empleos, etc. A los alumnos se los quiso seducir con promesas de que este año se eximirán con 5 o 6 puntos, y de que las clases terminarian un mes antes (...) En fin, la demagogia de Trabajo y Previsión llevada al orden educativo". 371

A partir de esta cita, y como veremos en adelante, desde Reconstruir y Acción Libertaria, la controversia con el peronismo en relación al rol de la universidad y de los intelectuales no se establecerá partiendo de un debate sobre ideas o concepciones acerca de la cuestión, sino más bien en relación al proceso o los acontecimientos que se sucederán en las instituciones educativas y de la cultura docta. Sin embargo, en Revista Americana de Educación hay lugar para el debate de ideas. Dirigida por Lunazzi, el director se nutre de una heteróclita y esporádica lista de colaboradores, que en muchos casos no comulgan con ideas libertarias pero si con las reformistas y anticlericales con respecto a la universidad y la educación en general. Aquí encontramos a Marta Samatán, santafesina referente del gremialismo docente y cercana al socialismo junto a Olga Cossettini, referente por su aporte a la pedagogía y la educación. ${ }^{372}$ Ligados específicamente al movimiento libertario, son numerosas las intervenciones de Rafael Grinfeld, representado en la revista como ejemplo de científico antifascista y militante de la ciencia por la paz y

\footnotetext{
${ }^{371}$ Reconstruir, $\mathrm{N}^{\mathrm{o}}$ 5, agosto de 1946. Pág. 2.

${ }^{372}$ Cossettini fue desplazada de su cargo en la escuela experimental de Rosario en el año 1946, y participó en esos años del Colegio Libre de Estudios Superiores. Sus postulados con respecto a la educación de niños y niñas coincidían en gran parte con aquellos planteos del anarquismo, al pujar por una escuela libre de discriminación por género, con compromiso comunitario y como espacio de socialización de toda la comunidad en su conjunto. Dora Barrancos ha desarrollado ampliamente las apuestas educativas del anarquismo argentino. Del mismo modo, Sandra Mc Gee Deutsch ha identificado las experiencias educativas en comunidades judías anarquistas en la región del Litoral. Mc. Gee Deutsch, Sandra (2012). Crossing borders ..., op. cit.
} 
Floreal Ferrara, en estos tiempos estudiante de medicina en la UNLP y representado por Lunazzi como ejemplo de estudiante comprometido con la reforma y opositor al peronismo.

Las notas que componen la Revista Americana de Educación se caracterizan por un análisis menos ligado a la coyuntura, a los sucesos diarios, pero igualmente abocados a la denuncia de las formas en que el peronismo en el estado concibe la educación. Fundamentalmente, acompañan las propuestas de agremiación docente y describen los puntos y manifiestos que han sido resueltos en las mismas. Relacionamos esta cantidad de páginas dedicadas a la agenda de las luchas docentes con el hecho de que Samatán y Cossettini tienen una activa participación en las organizaciones sindicales docentes a nivel local y continental. $^{373}$

María Luisa Berrondo, reconocida referente del socialismo platense, también escribirá sobre temas educativos en Reconstruir, plasmando allí una mirada liberal, sarmientina y reformista en cuanto al rol del Estado y su importancia para garantizar una educación obligatoria, libre y laica. ${ }^{374}$ Reconocida anticlerical, puede ser este un elemento que cohesiona las heteróclitas opiniones, participaciones y personalidades dentro de la revista.

Las constantes referencias a la necesaria relación entre el Estado y la Educación pública, gratuita y universal, se explican, en este caso, por la heterogeneidad de opiniones dentro del mismo proyecto editorial, fundamentalmente porque Lunnazzi apuesta por una estructura federativa y autogestionada para la educación en todos sus niveles, lo que parecería estar en oposición a los reclamos de los gremios docentes, de los que también se hace eco la revista. ${ }^{375}$

\footnotetext{
${ }^{373}$ R.A.E. $\mathrm{N}^{\mathrm{o}} 2,3,4$ y sucesivas.

${ }^{374}$ El artículo de María Berrondo es un extracto de una conferencia dictada en septiembre de 1946 en el Centro Socialista de Villa Mitre. Resumidamente, en la exposición, la autora rechaza el reemplazo de las figuras mentoras de la nación argentina por parte del peronismo, que se refleja en los nuevos planes educativos que dan por tierra a la Ley 1420: Juan Manuel de Rosas por Juana Manso, Alberdi o Sarmiento. Reconstruir, N ${ }^{\circ}$ 7, Septiembre de 1946.
}

${ }^{375}$ R.A.E. $\mathrm{N}^{\circ} 1$, julio de 1946. 
Otro modo de avasallamiento de la autonomía universitaria, y del sistema educativo en general, es la enseñanza religiosa y la injerencia de la Iglesia Católica. Reconstruir reserva un espacio privilegiado para la denuncia del rol de la Iglesia católica argentina en la educación y en el sistema político democrático. Según entienden, el apoyo eclesiástico a Perón fue fundamental para su triunfo en las elecciones presidenciales. A cambio, Perón habría entregado el sistema educativo a la Iglesia, incluso las universidades.

"El clero ha contribuido al triunfo del hombre repudiado por lo más esclarecido de la conciencia política del país. Ha sido consecuente con la simpatía disimulada o franca-según las circunstancias- con que saludó al nazismo. ¿Cuál es el precio de este apoyo de la iglesia católica al encubrimiento del coronel Perón? Acaso la entrega de toda la enseñanza oficial a su total control e inspiración de su rumbo. Aún más grave resulta la intromisión de la iglesia católica en el plano pedagógico, puesto que la enseñanza en manos de monjas y sacerdotes implica la pérdida segura de la calidad en los contenidos y la enseñanza",376

Juan Lazarte, en un acto realizado en Rosario por la Junta Para la Defensa del Laicismo y de la Libertad de Creencias, señalaba que la enseñanza de la religión católica en las escuelas "provoca un choque absurdo entre los conocimientos que otorga el progreso de las ciencias, de las artes y de la cultura, y los preconceptos y supersticiones religiosas". 377 Las denuncias hacia la implementación de la enseñanza religiosa se exacerbaron a partir de 1947, año en el cual se sanciona la ley. Pero en el primer año de publicación de Reconstruir, las actividades llevadas adelante por el catolicismo para lograr la efectivización de la ley, también fueron registradas. Un ejemplo de ello es la noticia sobre la realización del congreso de la Juventud Católica, al que titulan "congreso de la decrepitud", cuyos fines serían fomentar la intolerancia religiosa, imponer la

\footnotetext{
${ }^{376}$ Reconstruir, 1946, № 5. Pág. 5.

${ }^{377}$ Reconstruir, 1946, № 10. Pág. 8. 
catequización en las escuelas, obtener subsidios para la iglesia y convencer a la juventud de "que la mayor y mejor diversión es concurrir a la iglesia". 378

Como ya lo hemos afirmado, desde la mirada de los anarquistas del periódico, el peronismo fue visto y homologado a los fascismos europeos y Perón fue identificado con las figuras de aquellos regímenes. La sanción de la obligatoriedad de la enseñanza religiosa, era para las/os libertarios, una de las tantas coincidencias que veían en el peronismo con los regímenes totalitarios europeos. En especial con el régimen franquista, que había dispuesto la enseñanza religiosa en las escuelas primarias en $1945 .{ }^{379}$ Para el anarquismo como para la mayoría de los grupos y partidos políticos opuestos al peronismo (de izquierda y de tendencia liberal), la lucha contra la ley se volvió bandera de la lucha anti-fascista. De este modo, señalaban que

"ahora por ley, ahora autorizados por el contubernio grotesco de nacionalistas, adeptos de la Acción Católica, laboristas y “obreros” de nueva conciencia-piedras del adefesio totalitario que tiene en la cúspide al "conductor”- atacan lo que es el fruto maestro, esperanza nuestra". 380

La enseñanza religiosa era contraria a los fines perseguidos por las /os ácratas, ya que buscaba “...hacer muñecos, esclavos, hombres y mujeres domesticados, inhibidos para la vida libre, para la lucha por la libertad". ${ }^{381}$

\section{Movilización estudiantil y agrupaciones de científicos e intelectuales}

\footnotetext{
${ }^{378}$ Reconstruir, 1946, № 5 . Tapa.

${ }^{379}$ Viñao, Antonio (2004). Escuela para todos: educación y modernidad en la España del siglo XX. Marcial Pons Historia, Madrid.

${ }^{380}$ Reconstruir, $\mathrm{N}^{\mathrm{o}} 13$, 1947. Pág. 1

${ }^{381}$ Reconstruir, $\mathrm{N}^{\circ} 13,1947$. Pág. 1

Bordagaray, M. E. Controversias libertarias: la interpelación anarquista en tiempos del peronismo 200
} 
Como ya hemos descripto en el capítulo 1, la apelación a sujetos que no necesariamente adscriben a los sectores trabajadores o de la clase obrera, es una 
característica del llamado de los anarquistas argentinos a partir de la década del 30 .

"La Federación Anarco-Comunista Argentina, declara: Que no es posible una solución de los graves problemas sociales sin una profunda transformación de las normas de convivencia, es decir, sin el conjunto de cambios de orden económico, político y moral que designamos con el nombre de Revolución Social. Que esa profunda transformación deberá ser realizada por el conjunto de las masas laboriosas y oprimidas, esto es por los trabajadores de la ciudad y del campo, por los obreros manuales, intelectuales, técnicos, etc., que sufren hoy las consecuencias de la explotación capitalista". ${ }^{382}$

Esta nueva apelación se relaciona fundamentalmente con los aspectos doctrinales que se discuten no solamente entre los colectivos libertarios locales que apuestan a una organización única y bajo las ideas del comunismo libertario o anarco comunismo. Como bien señala López Trujillo, los debates sostenidos por quienes apuestan a una organización única del anarquismo para la Argentina son extensos y controversiales. Resumidamente, tratan acerca del tipo de organización deseada, críticas a lo actuado por el anarquismo en las décadas anteriores y las características que debiera tener la "nueva sociedad" emplazada sobre las bases del comunismo libertario. ${ }^{383}$ A través de A.L., se evidencia la necesidad de situar los principios doctrinales sobre los que se apoyará la naciente organización en los artículos en los que "hacen hablar" a los grandes teóricos fundadores del anarquismo occidental. Kropotkin es citado en cuanto a sus apreciaciones con respecto a los fracasos que ha sufrido el anarquismo mundial. La experiencia rusa parece haber puesto en evidencia que la falta de organización y de un programa general para el anarquismo fue nefasto para su propia existencia, al mismo tiempo que la experiencia organizativa bolchevique habla a las claras de aquello que bien hicieron para llevar adelante el proceso revolucionario. ${ }^{384}$

${ }^{382}$ F.A.C.A. (1935) "Resoluciones aprobadas en el Congreso Constituyente de la Federación Anarco-Comunista." s/d.

${ }^{383}$ López Trujillo, Fernando (2005). Vidas en rojo y negro..., op. cit.

${ }^{384}$ Ibídem, 
La importancia de la movilización de los jóvenes en esta nueva etapa emprendida en 1933 y materializada en la organización en 1935, es destacada por el mismo autor y por los propios militantes fundadores de la FACA. De las Resoluciones del primer Congreso de la FACA, percibimos el impulso a la creación de numerosas organizaciones para los diversos "frentes". La Asociación de Juventudes Libertarias pretende nuclear y dirigir la acción de los jóvenes libertarios del país. Pero su acción aún no se enfoca en el mundo estudiantil, sino más bien en los jóvenes obreros y desocupados que parecen ofrecer una gran posibilidad de movilización frente a la crisis económica y moral que enfrenta el capitalismo. En 1941, aparece la publicación Avanzada! perteneciente a las Juventudes Libertarias de Buenos Aires. En su declaración inicial, observamos que no solamente apela al joven obrero o excluido: “Compañero: Los jóvenes libertarios nos dirigimos a ti, muchacho de la fábrica, el campo o las aulas. Queremos decirte qué pensamos y qué sentimos en estos terribles momentos actuales". 385

Del mismo modo, en la publicación juvenil aparece también la lucha contra el fascismo como bandera de movilización:

"Los Laval y los Petain; los decretos de Castillo y Culaciatti, amordazando, ahogando toda expresión popular, coartando la libertad de prensa, de palabra, de asociación y de reunión. (...) Los jóvenes libertarios llamamos a la lucha activa contra el fascismo". ${ }^{386}$

Así como el peronismo define nuevas problemáticas para el agenciamiento y movilización ácratas, el escenario internacional y los sucesos europeos también tienen su impronta en las alocuciones libertarias locales. En esta construcción (de discursos y de acción) fue definitiva, sin duda, la experiencia española. ${ }^{387}$

El golpe militar de 1943, y el posterior encarcelamiento de muchos militantes libertarios junto al cierre y confiscación de sus publicaciones

\footnotetext{
${ }^{385}$ Avanzada! Órgano de las Juventudes Libertarias de Buenos Aires, 1941, № 1. Pág.1.

${ }^{386}$ Avanzada! Órgano de las Juventudes Libertarias de Buenos Aires, 1941, № 1. Pág. 2.

387 Creada en 1932, en el marco de la Segunda República Española, la Federación Ibérica de Juventudes Libertarias pivotea entre la independencia con respecto a la CNT y la FAI y la participación como grupos de acción y promoción de cultura y propaganda ligados a las organizaciones generales del anarquismo. Fernández Soria, Juan Manuel (1996). Cultura y libertad.
} 
interrumpen, fundamentalmente por la escasez de documentos con los que contamos, la posibilidad de establecer una cronología precisa sobre las agencias de los colectivos juveniles anarquistas. Sin embargo, en uno de los últimos números de A.L. del año 1943 (antes de ser clausurados sus talleres y encarcelados sus editores) aparece el llamado a los jóvenes estudiantes universitarios, frente a la intervención de las Universidades de Cuyo y del Litoral. El periódico establece una línea directa entre aquel movimiento estudiantil que impulsó el movimiento reformista de 1918 y los que en este momento, frente al avasallamiento del Estado militar, deben salir a las calles para sostenerlos:

"Para impedir que la Universidad se someta a la arbitraria dominación militar, los estudiantes tienen que elegir entre la derrota sin gloria que puede significar su silencio, o la lucha dignificadora que los proteja contra los planes que arrasarán con cuanto existe de digno en su vida y en su esfera de acción. La Universidad puede oponer una eficaz barrera a los enemigos de su autonomía y libre desenvolvimiento. Todo depende de la posición que adopte la juventud, de su disposición combativa, de su espíritu de consciente rebeldia". ${ }^{423}$

De este modo, en tiempos en que gran parte de los propagandistas libertarios es encarcelada y los medios de publicización de sus acciones clausurados, la apelación al movimiento estudiantil se asemeja a lo que en tiempos del peronismo en el gobierno, sucede con las mujeres. Estos antecedentes, sumados al proceso descripto en el capítulo 1 acerca de los sucesos de 1945 en la universidad de La Plata, remiten a diferentes cronologías en cuanto la interdefinición de los tres actores que hemos identificado para seguir los modos de apelación libertarios.

La educación en las juventudes libertarias. Universidad de Valencia, Cuadernos del Departamento de Educación Comparada e Historia de la Educación.

${ }^{423}$ A.L., N ${ }^{\circ}$ 67, agosto de 1943. Pág. 2.

Fundamentalmente, a partir de 1945, pero con mayor intensidad a partir de 1946, el apoyo y la reivindicación del movimiento estudiantil son relevantes y constantes en todas las publicaciones analizadas. El movimiento estudiantil, entre 
quienes encontramos grupos libertarios, será el ejemplo de lucha en primer lugar y de resistencia posteriormente, frente a la implementación de las nuevas políticas universitarias impulsadas por el peronismo. Pero no sólo eso. En un escenario en el que los sujetos que históricamente han perseguido los mismos ideales de la izquierda o al menos de la movilización en pro de la mejora en las condiciones de vida (léase clases obrera o sectores populares) se vuelcan masivamente hacia el peronismo, los colectivos libertarios toman como referentes a aquellos grupo/sujetos/actores que se mantienen al margen o en clara oposición al nuevo movimiento político, ahora con forma de Estado y la legitimidad de las urnas.

Como hemos visto en el capítulo dedicado a los obreros, el anarquismo comienza por criticar la demagogia y la política "para las masas", así como al movimiento obrero que lo apoya también masivamente. Es por eso que la movilización de los aliados, en el caso del movimiento estudiantil, parte de pensar en un actor numérica y socialmente acotado, en cuanto a que los jóvenes que logran acceder a la educación superior está aún limitada a las clases medias y urbanas. ${ }^{388}$ En cuanto a su extracción política, los colectivos libertarios también comprenden que el apoyo a la causa reformista y antifascista/antiperonista no necesariamente encastra con una identificación anarquista. Sin embargo, cuentan con la experiencia previa de activación y protagonismo que los referentes docentes de la UNLP supieron construir en tiempos de la intervención y los años previos.

Es ilustrativa de lo anterior, la noticia en Reconstruir sobre la acción de un grupo de alumnos en ocasión del renunciamiento de Rafael Grinfeld a sus cátedras e instituto en la UNLP.

"Los alumnos del profesor Grinfeld se han negado a asistir a clases dictadas por cualquier reemplazante. Las autoridades amenazan a los estudiantes y padres de los mismos coaccionándolos y anunciando la adopción de medidas realmente drásticas (...)”. ${ }^{389}$

El mismo artículo refiere a la Federación Universitaria de La Plata como colectivo estudiantil que acompaña estas "resistencias", pero que además lleva el

\footnotetext{
${ }^{388}$ Historia de la clase media

${ }^{389}$ Reconstruir, $\mathrm{N}^{\circ}$ 2, julio de 1946.
} 
reclamo un paso más allá: declara una huelga estudiantil (en los colegios y facultades). El problema que presentan estas acciones juveniles es, según Reconstruir, que carecen de fundamentos ideológicos profundos. Es decir, que sus acciones se limitan a resolver situaciones concretas puntuales, pero les falta embanderarse tras ideas concretas y utópicas para la revolución socialista libertaria:

"Para actuar con eficacia, la juventud necesita tener ideales revolucionarios. No importa que parezcan de contornos utópicos y de realización lejana. Los ideales nunca se realizan del todo, pero sirven para avanzar, para crear. Son los móviles de toda acción fecunda y perdurable. Hay que fijarse objetivos amplios sin dejar de ser claros y precisos (...)". 390

De todos modos, las consideraciones de Reconstruir y Acción Libertaria con respecto al movimiento juvenil/ estudiantil pivoteará entre estas dos consideraciones: por un lado serán reconocidas y publicitadas las acciones llevadas a cabo por el movimiento estudiantil en ocasión de acompañar la "resistencia" de docentes universitarios y contra la reforma en los estatutos y planes de estudio. Por otro lado, la crítica a esas acciones que resuelven problemas en lo inmediato pero que carecen de un trasfondo ideológico que las guíe. ${ }^{391}$

En síntesis, reformismo y trayectoria antifascista/peronista de los intelectuales y docentes libertarios, construyen el relato por el cual la movilización estudiantil deberá responder al llamado (mediado de acuerdo a la línea editorial de cada una de las publicaciones que ya hemos descripto) libertario.

En relación a los científicos y docentes universitarios, es posible establecer una especie de "mapa" de organizaciones, juntas y agrupaciones profesionales que,

\footnotetext{
${ }^{390}$ Reconstruir, № 6, septiembre de 1946. Pág. 10

${ }^{391}$ Incluso en un mismo artículo, reconocimiento y crítica conforman el argumento por medio del cual Reconstruir apela al estudiantado. Con motivo de una huelga estudiantil en las universidades del Litoral, La Plata y Buenos Aires motivada por la oposición a los cambios que comienzan a introducirse en la institución (reemplazo de docentes, injerencia del Ejecutivo en las cuestiones internas, cambios en los programas de las carreras), Reconstruir refuerza su discurso propedéutico con respecto a "la idea" y la necesidad de su implantación entre la juventud: "La tolerancia estudiantil tiene un límite, y ese límite está sobrepasado ya. Ha llegado el momento de la organización de la resistencia, de la preparación intensa de una acción a fondo que no debe demorarse. No habrá nada que detenga la firme decisión juvenil en su pugna por su libertad de expresión (...)”. Reconstruir, $\mathrm{N}^{\mathrm{o}}$ 7, septiembre de 1946. Pág. 1
} 
identificadas por el periódico, dan cuenta de una acción organizada en grupos de afinidad profesional y que en muchos casos, puede llegar a ser también ideológica.

$\mathrm{Al}$ menos en los primeros 10 números de ambas publicaciones, la mención a las desventuras del gobierno peronista y su incursión en la universidad es permanente. No sólo refiere a la lucha de los estudiantes de los colegios y de las facultades (como describimos más arriba), sino a rescatar fundamentalmente la figura de los docentes expulsados o dejados cesantes de sus cargos, destacando a Rafael Grinfeld y Jose Lunazzi como paradigma y ejemplo de lo que el peronismo piensa hacer con el sistema educativo argentino. ${ }^{392}$ Son constantes las menciones a Rafael Grinfeld y su convocatoria a un Congreso Científico por la Paz Mundial. La apuesta es a una reunión de matemáticos, químicos, ingenieros, y otros profesionales, que puedan establecer acuerdos para la lucha contra la guerra cuyo máximo y peor exponente es la creación de la bomba atómica. Y son los hombres de ciencia, según Grinfeld, quienes deben dar el aporte fundamental para esa resistencia. El fin último es crear un organismo internacional de investigaciones científicas que impongan el deber de no colaborar con la creación de bombas atómicas en sus respectivos países. ${ }^{393}$

Otro ejemplo de agrupaciones científicas o profesionales lo da, según Reconstruir, la Junta de Sanidad en Rosario, seguramente fundada o impulsada por Juan Lazarte. El periódico denuncia de manera similar los sucesos en la universidad, la cesantía de 4 médicos de la ciudad por decreto municipal del entonces intendente Enrique Schmidt. ${ }^{394}$

\footnotetext{
${ }^{392}$ Reconstruir, agosto de $1946, \mathrm{~N}^{\circ} 5$.

${ }^{393}$ R.A.E., 1946, $\mathrm{N}^{\circ} 1$.

${ }^{394}$ Reconstruir, $\mathrm{N}^{\mathrm{0}} 7$, septiembre de 1946. 
En la generalidad, Lunazzi, Grinfeld y Lazarte con acciones concretas, y Reconstruir y Acción Libertaria como medio de publicitación de las acciones, proponen la organización sindical de las profesiones liberales para recuperar los espacios de los que han sido expulsados (como los médicos del sistema sanitario, los docentes del sistema educativo, los ingenieros, abogados, etc.) y reclama al "movimiento obrero" que haga suya la causa de la ciencia y el arte. Porque el advenimiento de una nueva sociedad no es posible sin un cambio cultural, el que lleva a científicos, artistas y profesionales como sus motores. ${ }^{395}$ La apuesta no sólo se limita a la denuncia de una situación desfavorable para aquellos sectores expulsados de los organismos estatales por parte del peronismo, sino que también propone esa construcción paralela en conjunto, similar a lo que observamos anteriormente en los tiempos de participación pública en la universidad.

\section{Jóvenes y universitarios en las estructuras organizativas libertarias}

“Ahora, apuntalada nuestra pequeña organización, con una obra hecha y muchas obras por hacer - la más grande, edificar, construir el socialismo- presentamos nuestra memoria y balance y al hacerlo, queremos saludar a cuantos piensan y trabajan por un mundo mejor: a la juventud universitaria y obrera, que no ha renunciado a ser digna y libre: a la F.U.A. y a la F.O.R.A."396

La cita con la que abrimos este apartado supone dos actores que, ya enrolados en las ideas libertarias, se movilizan junto a la U.S.L. de Buenos Aires.

Sin embargo, en este momento es necesario referir los problemas "internos", el de los intereses contrapuestos entre los mismos militantes libertarios, que proponen diferentes estrategias de movilización para los sujetos universitarios. Creemos que

\footnotetext{
395 Lunazzi, José María (1946). "Discurso pronunciado en acto por el día del estudiante en las puertas de la Universidad de LA Plata, 21 de septiembre de 1945"en Revista Americana de Educación, № 2.

${ }^{396}$ Unión Socialista Libertaria de Buenos Aires (1948). Memoria y Balance. s/d
} 
de este modo podremos explicar el desenlace de la controversia por medio de la cual el movimiento libertario apela a los universitarios para disputar la hegemonía peronista. Si bien ya hemos descripto en el capítulo 3 las características de las Uniones Socialistas Libertarias, y las diferencias dogmáticas e ideológicas entre estas y la organización FACA, en este apartado profundizaremos en las diferentes percepciones acerca de las acciones organizativas necesarias para encauzar la lucha estudiantil.

En las memorias sobre lo actuado entre 1946 y 1948, el informe de la USL de Buenos Aires da cuenta de la importancia que tiene la participación de amplios sectores sociales para el sostenimiento del proyecto. Si bien financieramente, se sostienen del aporte solidario de sus simpatizantes, la realidad de sus finanzas da cuenta a las claras de que ese aporte económico se reduce a los miembros organizadores y no a todos aquellos que participan de sus actividades. ${ }^{397}$ Del mismo modo, ese interés por sostener un llamado amplio y solidario a todos quienes acuerden en construir un espacio de resistencia y construcción de una cultura socialista libertaria, se traduce en actividades dirigidas fundamentalmente a la juventud: actividades recreativas y salidas expedicionarias grupales, prácticas de lectura y discusiones grupales para interesar e incorporar a los jóvenes en los clásicos de la literatura anarquistas, apoyo a los jóvenes que participan en el movimiento estudiantil movilizados desde la F.U.A y la F.U.L.P. ${ }^{434}$

Según quienes escriben la "Memoria" de la USL de Capital Federal, es tan dinámica y potente la participación de la juventud en sus actividades, que resulta necesaria la creación de un espacio que nuclee toda esa energía propositiva:

“(...) se han constituido las Juventudes Socialistas Libertarias de U.S.L (...) Conserva su total independencia y su obra, bien conocida por todos, dice de las innumerables tareas realizadas bajo su responsabilidad, como asi también, de la participación activa en la

\footnotetext{
${ }^{397}$ U.S.L (1948) "Memoria y balance", s/d.

${ }^{434}$ Ibídem.
} 
dirección de nuestro movimiento, a quienes debemos, en gran parte, el éxito de nuestros actos y de nuestra labor en general". 398

Según la cita, los dos años sucedidos entre la creación de la U.S.L. y el informe de 1948, tuvieron como principales impulsores de la agrupación general a la juventud. Esto ameritó una reformulación en los objetivos planteados en sus comienzos. Por un lado, vincular más estrechamente las prácticas políticas vinculadas a los espacios tradicionales del anarquismo (como los círculos de lectura, las reuniones culturales, los actos políticos conmemorativos) con los de los jóvenes. En segundo lugar, significó también el focalizar en este segmento particular sus acciones organizativas. La totalidad de las apuestas públicas de la U.S.L. de Capital, comenzaron a llevarse a cabo en el local de las J.S.L. ${ }^{399}$ Conversaciones y conferencias con referentes como José Guardia y José María Lunazzi, así como también viajes al Tigre o zonas ribereñas, forman parte del programa general de la U.S.L. ${ }^{400}$

Como hemos descripto en los apartados anteriores, la activación libertaria en las agrupaciones estudiantiles era presupuesta para quienes elaboraban el programa de las U.S.L. de 1946 y para el colectivo que editaba el periódico Reconstruir. Es decir, confiaban en que las acciones de protesta llevadas adelante por organizaciones como la F.U.A o la F.U.L.P derivarían inevitablemente en su embanderamiento por los principios libertarios. Percibían en estas acciones de protesta y de resistencia ante el avance del estado sobre la autonomía universitaria,

\footnotetext{
398 Ibídem.

${ }^{399}$ Ibídem.

${ }^{400}$ En el imaginario de quienes editan el documento (miembros fundadores de la U.S.L. entre los que se avizora la pluma de Herminia Brumana), la participación política de la juventud requería de ciertos cuidados para ser noble y sostenida en el tiempo: "Un núcleo entusiasta de jóvenes del movimiento libertario y simpatizantes de éste auscultando la intensa necesidad sentida por los que cotidianamente trajinamos en la actuación han llegado a tomar acuerdo en promover, entre los amigos libertarios y progresistas, la creación de un Centro Excursionistas, cuya finalidad responda vividamente al desarrollo natural de nuestra juventud, construyendo las bases materiales y el clima espiritual indispensable para que sus corazones sepan también de fiestas. Los desgastes que el estudio, el trabajo, las preocupaciones hogareñas de todas las horas, la nerviosidad que una permanente militancia producen hacen que hayamos pensado en crear coordinada $y$ cohesionadamente, una entidad que nos ofrezca por algunos instantes, ese baño lustral que necesitamos para refrescarnos y purificarnos". De este modo, la naturaleza juvenil necesitaría de esos espacios de recreación para fortalecer al mismo tiempo sus convicciones y la solidaridad entre compañeros. Sobre los espacios de socialización y de sociabilidad en las culturas políticas de izquierda en la Argentina, ver Bisso, Andrés (2009). Sociabilidad, política y movilización: cuatro recorridos bonaerenses 1932-1943. Buenos Aires, Buenos Libros.
} 
un núcleo de acción antisistema. Encaminado por aquellos jóvenes con militancia anarquista concreta, se convertirían rápidamente en grupos afines al anarquismo.

Sin embargo, a partir de 1948 se observa, por un lado, el cese de publicación de las acciones de estos colectivos estudiantiles por parte de la prensa libertaria (léase A.L. y Reconstruir). Además, comienza a establecerse un parámetro sobre el cual debería estructurarse un movimiento estudiantil libertario. La heterogeneidad de las propuestas organizativas definirá posteriormente una oposición concreta que terminará con las buenas relaciones entre los colectivos citados. Por un lado la F.A.C.A. avizora un panorama muy oscuro para un movimiento estudiantil que no puede sobreponerse a las acciones represivas e intervencionistas constantes por parte del Estado. Lejos de imaginar una construcción amplia del movimiento estudiantil en su conjunto, propone una organización explícitamente anarquista para la activación juvenil:

"Es necesario ganar para nuestra causa a la juventud pletórica de energías y despertar en ella sentimientos de libertad, de justicia, de desprendimiento, de humanidad. Para ello necesitamos dos cosas: voluntad y organización", 401

Si bien establecida sobre valores amplios, la organización anarquista es necesaria. La diferencia la U.S.L. de Capital Federal y Acción Libertaria reside en las formas y los contenidos de esas organizaciones juveniles y estudiantiles, ahora sí guiadas por jóvenes libertarios o iniciados en "la idea".

En cuanto a las organizaciones de científicos e intelectuales, las menciones sólo se reducen al accionar de la Acción Laica Argentina (A.L.A.). Impulsada por Juan Lazarte desde Rosario, sus intervenciones se reducen a partir de 1948, a la denuncia de la educación estatal como brazo oculto de la dogmatización del clero y del despotismo. ${ }^{402}$ Del mismo modo que A.L.A., desde A.L. se promueve la educación en el hogar como trinchera frente a la imposibilidad del establecimiento de las "escuelas libres de dogmas:

\footnotetext{
401 “Los jóvenes libertarios deben organizarse". A.L., No 106, mayo de 1948. Pág. 3

${ }^{402}$ U.S.L. de Capital Federal (1948) Memoria y balance, s/d 
"En tanto no sea factible crear escuelas verdaderamente libres, es deber ineludible de los padres que velan por la salud moral de los hijos, convertir los hogares en trincheras de combate contra las mentiras con que se presente envilecer y someter las almas 
infantiles, En cada hogar digno se debe inmunizar a los niños a los niños, para que la infección terrible del totalitarismo y del clericalismo no los contamine". ${ }^{403}$

No hemos hallado ninguna referencia en las fuentes sobre proyectos concretos por parte de los colectivos libertarios sobre escuelas libres para los años 1946-1953. Sin embargo, coinciden en general en la necesidad de ocupar espacios alternativos desde donde socializar con amplios sectores opositores al régimen peronista, como hemos descripto también en los apartados anteriores. Frente a la educación religiosa, la única opción viable por el momento es la educación paralela, en el hogar, desde donde sería posible "balancear" los contenidos con respecto a la recibida por parte del Estado en las escuelas públicas.

El llamado a una "agrupación de científicos" por la paz y la ciencia también desaparece del repertorio discursivo de estos colectivos. Rafael Grinfeld, principal impulsor de la idea, viaja a Venezuela y se establece como profesor universitario entre octubre de 1948 y julio de 1949. De regreso en la Argentina, trabaja en una fábrica de heladeras de la ciudad de La Plata, alejándose de los colectivos libertarios y de la universidad. ${ }^{404}$

\section{Consideraciones finales}

Si hay algún elemento que pueda relacionar las apuestas libertarias con las de las demás agrupaciones de intelectuales antiperonistas es que la crítica cultural permitía una serie de sutilezas y licencias, que precisamente fueron utilizadas también por los intelectuales anarquistas en sus intervenciones en los proyectos editoriales que hemos analizado. Por otro lado, en cierto sentido, el anarquismo se mimetiza en la batalla cultural emprendida contra el peronismo. A diferencia de lo

\footnotetext{
${ }^{403}$ A.L. $\mathrm{N}^{\mathrm{o}} 129$, mayo de 1949.

${ }^{404}$ En 1955, se reintegra a la Facultad de Ciencias Físicas de la Universidad de La Plata y es designado jefe del Departamento de Física de la UNLP, cargo que ejercerá hasta 1966 cuando un nuevo golpe militar lo alejará nuevamente del país. Como consecuencia de un accidente automovilístico, muere en Costa Rica en Costa Rica en 1969
} 
analizado en "la cuestión obrera" y "las mujeres", en donde realizan críticas a otros espacios y/o partidos políticos no peronistas en el afán de disputar sujetos, los anarquistas apelan en este caso a identificarse con todo el arco opositor al peronismo que plantea la "resistencia cultural" frente al totalitarismo y el avasallamiento. Por otro lado, parecería que sus interlocutores los aceptan y comparten sus mismas percepciones acerca del fenómeno peronista.

Sin duda, los repertorios de acción y movilización libertarios que apelan a los actores universitarios y científicos se reducen en este momento. Esto se produce no solamente por la imposibilidad de "interesar" a los sujetos, que si bien representan a la oposición más clara al gobierno peronista, no necesariamente se sienten interpelados por las organizaciones libertarias creadas con ese fin. Para ello, también debe tenerse en cuenta la dinámica política en la que estos colectivos inscriben sus acciones. Sin duda, el escenario en el que comienzan sus apuestas, en el año 1946, no será el mismo hacia fines de la década. Sobre estos cambios a nivel general, las dimensiones a tener en cuenta en la "arena pública" en que los colectivos anarquistas se incluyen y las respuestas obtenidas por el peronismo en el gobierno y por los sujetos interpelados, trataremos en las conclusiones generales de este trabajo.

Resta una reflexión sobre la "invisibilización” en la que estos anarquistas incurren. No aparecen mujeres en el mundo de los científicos ni en el de la militancia estudiantil. Si bien algunas profesionales como Lola Quiroga (médica odontóloga) o Ana Piacenza (abogada) son referentes dentro de las organizaciones, no percibimos un relato que las incluya como parte de estos sujetos a ser enrolados. Las mujeres nombradas son más bien, excepciones en el mundo profesional y también hacia dentro mismo de la militancia anarquista. Por otro lado, es digno de destacar que la revista R.A.E está dirigida a docentes, un universo feminizado casi en su totalidad. Sin embargo, no aparece un discurso generizado en cuanto a reconocer las particularidades de las mujeres que ejercen la docencia en tiempos en que se debaten los contenidos y la injerencia del estado peronista en esos espacios. $^{405}$

\footnotetext{
${ }^{405}$ Sobre las mujeres en el magisterio, ver Lobato, Mirta (2007). Historia de las trabajadoras en la Argentina ..., op. cit. Barrancos, Dora (2008) Mujeres en la sociedad argentina. .., op.cit. 
Al inicio de este capítulo mencionábamos el decurso general que la historiografía había desarrollado en torno a la figura del intelectual antiperonista, en el que primaban las referencias de la tradición liberal y en el que la fuerte carga unificadora del carácter opositor parecía haber borrado o al menos difuminado las marcas partidarias o ideológicas.

Si bien la estrategia de los intelectuales anarquistas parece haber transitado ese mismo espacio de indeterminación en pos de la apelación común antiperonista, parece notarse que la tradición de la radicalizada retórica libertaria, permitía "distinguir" el marco ideológico del foco de enunciación de estos intelectuales y universitarios anarquistas, más allá de sus intentos de integrarse de manera armónica en la mainstream antiperonista. Quizás la marca sobre la prédica anticlerical en tonos fuertemente combativos pueda precisar uno de los tonos más encarnecidos de esa distinción, demostrando los límites que la tradición ideológica puede-incluso- presentar a las estrategias de unificación política. 


\section{A MOdo de CONCLUSIón \\ DISIDENCIAS, TRAICIONES Y REPRESIÓN: \\ LOS MODOS EN QUE SE RESUELVEN LAS CONTROVERSIAS}

"Una controversia es el conjunto de expresiones mediante las cuales se cuestiona, discute, negocia, rechaza, etc. la representatividad de un portavoz". 406

Si es posible resumir los resultados obtenidos por los colectivos libertarios al disputar sujetos con el peronismo por medio de las controversias, deberíamos diferenciar tres dimensiones. La primera remite a la cuestión sobre si el fracaso de las controversias planteadas no puede interpretarse sin tener en cuenta la respuesta de ese "actor negativo" definido desde los comienzos. La segunda hace foco en Las diferencias internas del movimiento libertario. La tercera, finalmente, hace referencia a la falta de concurrencia de los sujetos interpelados al llamado libertario.

\section{El fracaso de las controversias planteadas no puede interpretarse sin} tener en cuenta la respuesta de ese "actor negativo" definido desde los comienzos.

¿De qué manera responde el gobierno presidido por Juan D. Perón a los desafíos que le propone el anarquismo?

La metodología propuesta en esta investigación incluye analizar la represión y la violencia como un indicador posible para medir la incumbencia de la

${ }^{406}$ Callon, Michelle (1986). "Some elements...”, op. cit. 
controversia planteada. ${ }^{407}$ Es decir, las controversias no habrían fracasado rotundamente si el contendiente negativo responde con violencia. La persecución y las actividades de espionaje realizadas por la Policía de la Provincia de Buenos Aires sobre las organizaciones libertarias han quedado registradas en los archivos que actualmente se encuentran bajo la órbita de la Comisión Provincial por la Memoria.

A pesar de las reformas en las cárceles y en el servicio penitenciario impulsadas por Roberto Pettinato, y la implantación de un modelo humanistacatólico en la consideración de los presidiarios, las tareas de espionaje y persecución a militantes políticos no parece haber sufrido grandes cambios con respecto a lo que sucedía en los anteriores gobiernos de facto. ${ }^{408}$ Según Barreneche, en el caso de la policía de la provincia de Buenos Aires, las reformas impulsadas por el peronismo se focalizaron en

\section{“(...) la centralización, el reforzamiento de la autoridad jerárquica y el afianzamiento del sistema de escalafones, todo ello conforme a los lineamientos del orden y la doctrina militar". 409}

Como bien lo aclara el autor, el control de las actividades sociales y políticas y la información sobre militantes y personas vinculadas a dichas actividades es un registro que la policía realiza con anterioridad al peronismo. Sin embargo, el crecimiento de la población y la complejidad de las acciones y las organizaciones, impulsan a la policía bonaerense a elaborar nuevas "pautas de trabajo", fundamentalmente para perfeccionar la metodología de seguimiento de las actividades públicas, cuyos informes eran enviados por las comisarías a la jefatura de policía. La reorganizada "División Orden Público" propuso la creación de ficheros regionales "en el que se registren los gremios obreros de la jurisdicción” y

\footnotetext{
${ }^{407}$ Ibídem

${ }^{408}$ Sobre este tema, ver Barreneche, O. (2007). La reforma policial del peronismo en la provincia de Buenos Aires, 1946-1951. Desarrollo económico, Vol 47, N 186. Silva, Jeremías (2012). "Las cárceles de la "Nueva Argentina": Administración del castigo y catolicismo durante el peronismo clásico", en Trabajos y Comunicaciones, 2da Época, $\mathrm{n}^{\mathbf{0}} 38$. http://trabajosycomunicaciones.fahce.unlp.edu.ar/. Silva, J. (2012). Las prisiones en la Nueva Argentina: Reforma penitenciaria, representaciones del castigo y usos políticos de las cárceles en el peronismo clásico (1946-1955). Tesis de Maestría en Ciencias Sociales). IDES-UNGS, Buenos Aires.

${ }^{409}$ Barreneche, Osvaldo (2010). "La policía de la provincia de Buenos Aires durante la primera mitad del siglo XX”, en Cuadernos de Antropología Social No 32. Pág. $42 .{ }^{447}$ Ibídem. Pág. 46.
} 
archivos conteniendo legajos "con los antecedentes de cada conflicto". Entre los datos a compilar no debían omitirse los nombres de los dirigentes, como así tampoco "gremio al que pertenecen y si éste se halla adherido a una central o es sindicato autónomo". 447

Hemos hallado este tipo de registro sobre las actividades de los anarquistas en la provincia de Buenos Aires, fundamentalmente para el año 1949. Clasificada como "información confidencial", existen registros e informes enviados por jefes policiales de diferentes localidades al Jefe de la Policía de la Provincia de Buenos Aires, en respuesta a pedidos de información sobre las actividades desarrolladas por la FACA. ${ }^{410}$ En esos documentos se informa sobre las actividades de la FACA, los lugares de reunión, la fecha de salida de Acción Libertaria y las comunicaciones que existen entre sus miembros. Por ejemplo, en un informe fechado el 8 de julio de 1949, El Jefe de Coordinación Federal, Mayor Jorge Osinde, remite al Jefe de la Policía de la Provincia de Buenos Aires, la siguiente información:

"Que la Federación Anarco Comunista Argentina (Laprida 1999Florida-Bs. As.-propicia la realización de una reunión a la que asistirán los compañeros que residen dentro de una zona que comprende el sud de Santa Fe y el norte de la Provincia de Buenos Aires.- Primeramente se tratará de obtener la conformidad por parte de la Unión Socialista Libertaria de Rosario, entidad que ya ha tratado de organizar una reunión de esta índole". 411

El informe incluye los puntos geográficos de irradiación del movimiento a través de la presencia de delegados libertarios:

"Se considera posible la participación de delegados que serían enviados desde las siguientes localidades.

Provincia de Buenos Aires: Rojas-Pergamino- Junín- ChacabucoArrecifes-Viñas- General Arenales- Colón- Salto.

Provincia de Santa Fe: Villa Cañás- Whelwright-Chabás- Hugues-

\footnotetext{
${ }^{410}$ Archivo DIPBA, Mesa C, Carpeta 1, Legajo No 25.

${ }^{411}$ Ibídem. Pág. 4.
} 
Arequito- Casilda- Teodelina- Firmat- Las Parejas- Elortondo-

Alcorta-Las Rosas- S. Spíritu- Chañar Ladeado- San Lorenzo-

Rosario (...)", ${ }^{412}$

La cita no sólo evidencia el seguimiento pormenorizado y la persecución encubierta que realiza la policía sobre la organización, sino que también describe un gran número de localidades en las que posiblemente se establece al menos un delegado o miembro de la FACA. Otra fuente de información sobre la persecución policial de la que son sujetos los miembros más activos del movimiento libertario son los periódicos. Acción Libertaria.

"La Unión Socialista Libertaria de Rosario cuyo local social fue clausurado por la tristemente célebre Comisión Bicameral hace más de una año, había organizado un acto conmemorativo del 1 de mayo, el que debía tener lugar en la plaza Sarmiento. La policía esperó a último momento para negar el permiso correspondiente, lo cual no impidió que los organizadores realizaran una profusa propaganda que atrajo al lugar numeroso público". 413

El grupo evidencia conocer muy bien las estrategias de los grupos policiales para con la represión. Además de dilatar la decisión sobre el permiso, envía grupos pertrechados al lugar donde se realizaría la actividad:

"También se hizo presente una nutrida representación policial, al parecer con instrucciones precisas de acción. Esta consistió en la disolución de los grupos reunidos y en la detención de varios compañeros, la mayoría de los cuales fueron puestos en libertad previo pago de una multa”. ${ }^{414}$

Las cabezas más visibles del movimiento -ya identificadas- quedan detenidas e incomunicadas, independientemente de la gravedad de la falta que se les impute:

\footnotetext{
412 Ibídem. Pág. 4.

413 “Proceso a Acción Libertaria”. A.L., № 130, junio de 1951. Pág 3.

414 “Proceso a Acción Libertaria”. A.L., № 130, junio de 1951. Pág 3.
} 
"Quedaron detenidos José Gunfeld y León Berdichevsky, quienes estuvieron incomunicados por cinco días en la policía federal, siendo sometidos a largos interrogatorios y procesados por desacato al presidente de la República, sobre la base de un Artículo de Acción Libertaria (...)". 415

En la misma nota, se informa que Acción Libertaria ha sido denunciada por desacato. La clausura del periódico Reconstruir, su traslado a Rosario y nuevamente el secuestro de sus maquinarias y el encarcelamiento de sus editores provoca la interrupción de su salida. ${ }^{416}$

En síntesis, la persecución policial, los procesos por desacato y las clausuras de sus publicaciones explican en gran medida las dificultades que tuvieron que enfrentar las organizaciones libertarias (particularmente a partir de 1949). Sin embargo, así como descreemos de las explicaciones que relacionan unilateralmente la desaparición del anarquismo por la represión y la persecución a sus militantes por parte del estado militar a partir de 1930, resulta indispensable recuperar la complejidad en las dimensiones a tener en cuenta para determinar este "final" para el anarquismo.

\section{Las diferencias internas}

La aparición del peronismo en la escena política representó un desafío para el amplio y diverso colectivo libertario, a partir del cual las acciones tendieron a recuperar los elementos y las perspectivas "compartidas", sobre las que era posible construir consensos. Esos lazos de posible unidad en la lucha contra la hegemonía peronista, se extendieron incluso a sectores, agrupaciones y organizaciones ajenas al propio movimiento libertario. Estas estrategias fueron diferenciadas y hemos reconocido los desarrollos específicos en ciudades como La Plata, Buenos Aires y Rosario. Del mismo modo que hacia fines de la década de 1930, las Juventudes Libertarias de Rosario proponían el trabajo conjunto con el Partido Comunista en

\footnotetext{
415 “Proceso a Acción Libertaria”. A.L., Nº 130, junio de 1951. Pág 3.

${ }^{416}$ Reconstruir, № 54, mayo de 1951. 
las organizaciones de base obreras, este tipo de alianzas estuvo ausente en las otras ciudades.

Sin duda, la figura de José Grunfeld resulta una referencia necesaria para comprender las acciones conjuntas con otros espacios. Durante su estadía en Santa Fe a partir de 1940 y su mirada crítica con respecto al estado postergado de los sectores rurales del sur de la provincia, coincidió en muchas ocasiones en acciones conjuntas la Federación Agraria Argentina. ${ }^{417}$ Del mismo modo se explica su participación en el socialismo platense y la Universidad Popular Alejandro Korn. Hemos referido que estas relaciones exceden el nivel personal, ya que muchas veces, organizaciones como la USL de La Plata y la de Rosario se manifestaron de manera pública en acciones conjuntas, en actos de homenaje, en la solidaridad frente a las sucesivas clausuras de los periódicos socialistas a partir del año 1947.

A esta etapa de trabajo en conjunto con colectivos heterogéneos, sobreviene una de fuertes debates y resquebrajamientos no solo en torno a esas alianzas establecidas para enfrentar el fenómeno del "fascismo-peronismo", sino también entre aquellas que de una u otra manera, desde el anarquismo, se relacionan con la FACA. A partir de 1949, se observa en las fuentes una férrea pugna entre aquellos que apuestan a las Uniones socialistas Libertarias como espacio de discusión, de conocimiento sobre cultura general, de integración de los jóvenes con orientaciones humanísticas y libertarias y aquellos que ligados orgánicamente a la FACA, pretenden imponer una agenda y un programa anarquista orgánico y apelan al trabajo militante dentro de las USL.

El objetivo de este segundo bando en la contienda es incorporar a la FACA a aquellos sectores que de una u otra manera sienten afinidad o participan en las USL, en especial los jóvenes. El nivel de violencia en este enfrentamiento llega a nosotros por medio de la voz de Diego Abad de Santillán, quien defiende la independencia de la USL de Buenos Aires frente al dogmatismo y la acción violenta de los

\footnotetext{
${ }^{417}$ Las interpretaciones historiográficas sobre la Federación Agraria Argentina son diversas: las que la consideran una corporación económica y los que ven ella una asociación de pequeños campesinos arrendatarios cuyo objetivo es el reconocimiento de sus derechos sobre la tierra. Ejemplo de las primeras: Bonaudo, Martha y Godoy, M. (1985). "Una corporación y su inserción en el proyecto agro-exportador: la Federación Agraria Argentina, (1912-1933)" en Anuario, N ${ }^{\circ} 11$, Facultad de Humanidades y Artes, Universidad Nacional de Rosario. Ansaldi identifica la lucha de los sectores agrarios enrolados en la Federación Agraria como ejemplo de las revueltas campesinas. Ansaldi, Waldo (1993). "Cosecha roja. La conflictividad obrero-rural en la región pampeana, 1900-1937", en Ansaldi, Waldo (comp.). Conflictos obrero-rurales pampeano. 1900-1937. Buenos Aires, CEAL.
} 
miembros de la FACA que participan en ella. En una circular interna, Abad de Santillán propone una encuesta ad referéndum, cuyo resultado definirá su alejamiento o permanencia dentro de la USL. Esta encuesta incluye aspectos sobre las cuales los asociados deberán definir su posición:

“1) La convivencia en la misma organización de elementos de mentalidad tan diversas como las que se pusieron de manifiesto en la asamblea no es admisible, si se tiene en vista un trabajo constructivo responsable. Si la mayoría de nuestros afiliados aprobase la continuidad de esa situación, pido que automáticamente aceptéis mi baja de la Unión, pues me sería imposible asistir a una nueva asamblea bajo esas condiciones". 418

La heterogeneidad de posiciones genera un escozor entre algunos de los militantes históricos como Abad de Santillán que las consideran incompatibles con el ideario libertario y para ello, pone de manifiesto su propia trayectoria como legitimación de su postura y sus propuestas:

"2 ${ }^{\circ}$ Habiendo hecho varios años de experiencias poco gratas y habiendo fracasado totalmente en los esfuerzos por armonizar el movimiento libertario, he llegado a la conclusión de que por ahora es imposible la coexistencia en la Unión Socialista Libertaria de miembros de la FACA. La consulta ad referéndum sobre este punto me parece imprescindible,. ${ }^{419}$

El tono en las palabras de Abad de Santillán habla a las claras de una crisis interna, de miradas opuestas sobre los pasos a seguir. Esta historia culmina con la

\footnotetext{
${ }^{418}$ Carta de Diego abad de Santillán a la Comisión Directiva de la USL de Capital Federal, en Unión Socialista Libertaria de Buenos Aires (1949). "Carta ad referéndum”, s/d

${ }^{419}$ Carta de Diego abad de Santillán a la Comisión Directiva de la USL de Capital Federal, en Unión Socialista Libertaria de Buenos Aires (1949). "Carta ad referéndum”, s/d 
desaparición de la USL de Buenos Aires desde 1949 y la persistencia de la FACA y de sus filas más orgánicas.

Sin embargo, surge una situación heterogénea respecto de esta problemática. En efecto, diferente es la situación de la USL de La Plata, en donde sus sostenedores combinan actividad editorial, propaganda, militancia y participación también orgánica en la FACA. Es el caso, por ejemplo, de José María Lunazzi.

El Tercer Congreso ordinario de FACA, realizado en la clandestinidad en el año 1951, tiene como eje de debate las estrategias de intervención en diferentes ámbitos en cuanto medio de adoctrinamiento en el ideario anarquista. Las acciones a seguir para los militantes orgánicos son por ejemplo:
"Propiciar la formación de grupos afines en las ciudades universitarias y la colaboración de los mismos y sus simpatizantes en los movimientos estudiantiles en defensa y por la ampliación de las conquistas de la Reforma Universitaria, tratando de impulsarlos hacia más claras definiciones". ${ }^{420}$

Así como hemos descripto la apelación a las mujeres, los obreros y los universitarios en los años inmediatamente anteriores, las actas del Tercer Congreso FACA dejan entrever que sus acciones se limitarán a la activación anarquista dentro del movimiento estudiantil, presuponiendo que en la juventud existe un germen libertario. La acción en el movimiento estudiantil,

“(...) servirá para captar un gran número de jóvenes que instintivamente llegan a una percepción anarquista, pero que luego se diluyen al no encontrar organismos para encauzar sus impulsos.". 421

Incluso proponen organizaciones con nombres específicos, como

\footnotetext{
${ }^{420}$ A.L., $\mathrm{N}^{\mathrm{o}} 137$, agosto de 1952.

${ }^{421}$ Ibídem.
} 
“Comisiones Estudiantiles de Coordinación Libertaria”. Dichas comisiones deberán constituirse necesariamente en organismos específicos dentro del movimiento universitario. $^{422}$

Relacionado con estas posturas menos heterodoxas con respecto a las presentes en los discursos anarquistas alrededor de 1946 y en los inicios de las controversias planteadas con el peronismo, el discurso sobre las mujeres y las agencias femeninas dentro del movimiento anarquista sufre profundas transformaciones. La intervención de Ana Piacenza en el Tercer Congreso Ordinario de la FACA como una manifestación de la utilización de la "fuerza" para lograr el interesamiento de las mujeres. En su presentación, manifiesta nuevamente la especificidad de la opresión de las mujeres (en sintonía con el planteo de Brumana).

“(...) la intervención de la mujer en la vida social, no depende exclusivamente de ellas. Los mismos factores que pesan sobre la voluntad del hombre, frenan la actividad y el pensamiento de la mujer, multiplicándose y agravándose para ella", ${ }^{423}$

Ahora, en 1951 y luego del triunfo eleccionario de Perón, es función de los hombres embanderados en las ideas libertarias, sacar del letargo a esas mujeres que no han logrado movilizarse ni oponerse activamente al nazi-peronismo. El llamado no es ya a todas las mujeres, sino (y por medio de los hombres) a las compañeras de ideas.

$$
\begin{aligned}
& \text { "Muchachas provenientes de hogares de llamados <compañeros }>\text {, } \\
& \text { suelen desconocer los principios libertarios y crecen con una } \\
& \text { mentalidad aburguesada, alimentando aspiraciones frivolas y } \\
& \text { mezquinas". }{ }^{2} 4
\end{aligned}
$$

Los compañeros hombres son los bastiones del socialismo libertario en tiempos en que ni las mujeres de su propia familia apoyan la causa. Pero no escapan

\footnotetext{
422 Ibídem.

${ }^{423}$ Piacenza, Ana (1951). "La mujer en la lucha social.” Mimeo. Informe presentado al Tercer Congreso Ordinario de la FACA.

${ }^{424}$ Ibídem.
} 
a su condición de género. Así la generalización de lo masculino con la violencia y la sumisión de las mujeres:

“(...) no se olviden que la mejor enseñanza radica en el ejemplo. El espectáculo degradante de padres crueles y arbitrarios que golpean a sus e hijos y compañeras; los insultos de los mayores a los menores en la familia". 425

De todas formas, según Piacenza, estos son “desvíos” en la conducta de los compañeros libertarios. Recordemos que en este caso, la exposición no se hace frente a un público (posible) amplio o heterogéneo, sino que es una comunicación interna para un congreso clandestino de la organización anarquista y en el que solo participan hombres, Piacenza es la única mujer que participa de él. ${ }^{426}$ Piacenza deja entrever la poca adhesión que el mismo colectivo libertario logra entre las mujeres de sus compañeros (madres, compañeras, hijas). Plantea que es necesario que incluyan a sus mujeres en actividades de propaganda, y llevarlas a las reuniones y festivales de los que ellos participan. Al mismo tiempo, sostiene que, más importante que su asistencia a las reuniones políticas, es llevarlas a las veladas culturales, teatrales y literarias, o a los pic- nics de camaradería. Así, acepta la veda para estas mujeres de los espacios de participación política más orgánica. En todo caso, si la mujer no acompaña, no ayuda y no milita en "la idea", por lo menos debería n capacitarse para ser buenas madres:

"No basta poner hijos en el mundo, alimentarlos, vestirlos y enviarlos a la escuela. (...) El niño no es amaestrable como los animales para que nos diviertan y no nos moleste. El niño tiene un mundo físico y moral muy distinto al nuestro (...)”. ${ }^{427}$

La clave, nuevamente, es capacitarse para ello. Resta mencionar que la existencia de la Unión de Mujeres Socialistas Libertarias de Rosario no parece haber sobrepasado el año de existencia. Por otro lado, Herminia Brumana tampoco continúa su actividad como miembro de la USL de Capital Federal más allá de 1948. Por último, las características de la militancia de estas mujeres pueden dar

\footnotetext{
${ }^{425}$ Ibídem.

${ }^{426}$ Actas del Tercer Congreso Ordinario de la FACA, 1951. s/d

${ }^{427}$ Piacenza, Ana (1951). “La mujer en la lucha social”..., op. cit. 
cuenta de los derroteros del movimiento en el que participan y del fracaso en el establecimiento de la controversia con el peronismo para lograr el apoyo de las mujeres. Son individualidades muy activas, pero sólo individualidades. Es por eso que en los años del peronismo, con casi 20 años de militancia en el anarquismo (y en otros espacios) será imposible individualizar o separar las trayectorias personales de las organizativas, ya que cada una de ellas (Brumana, Pavón, Piacenza) representan no solo los perfiles de las militantes libertarias, sino que definen los derroteros en los que el colectivo libertario se ha inscripto. Es imposible diferenciar todas las estrategias y controversias que hemos analizado de las personalidades que las han forjado.

Con la muerte de Iris Pavón, en 1951; y de Herminia Brumana, en 1952, desaparecen no solamente dos figuras fundamentales para el agenciamiento de las mujeres en clave libertaria, sino que con ellas desaparecen también las experiencias organizativas que sostuvieron

En resumen, los fracasos organizativos, las disputas internas y el endurecimiento doctrinal parecen haber sido el resultado obtenido por el colectivo libertario luego de los primeros años de gobierno peronista.

\section{3- La no concurrencia de los sujetos interpelados al llamado libertario.}

Esta dimensión se relaciona con aquellas interpretaciones que veían una incongruencia o un desfasaje entre las apuestas políticas e ideológicas del anarquismo (el de la FORA en la década del 20) y una sociedad en proceso de transformación. La anacronía entre la interpelación anarquista y los intereses de los sujetos a los que interpela puede ser una dimensión necesaria para esta conclusión.

Si consideramos al sujeto "mujeres" y "obreros", el triunfo de Perón en las elecciones de 1951 fue interpretado por Reconstruir como una derrota. ${ }^{428}$ El interesamiento, si se logra, confirma (más o menos completamente) la validez de la problematización y la alianza que implica. En este caso de estudio concreto, la

\footnotetext{
${ }^{428}$ A.L., $\mathrm{N}^{\mathrm{o}} 133$, diciembre de 1951. Reconstruir, $\mathrm{N}^{\mathrm{o}}$ 57, diciembre de 1951. Sobre las elecciones de 1951 y el voto de las mujeres, ver Valobra, Adriana (2008). "La ciudadanía política de las mujeres y las elecciones de 1951", en Anuario de Historia Argentina, № 8.
} 
problematización acabó por refutarse. Resulta enriquecedor para este análisis, incluir la noción de "prueba". Según Latour, los actores buscan aliados que refuercen su posición. En palabras de Nardacchione,

“(...) el incremento de aliados tiende a incrementar las capacidades (de fuerza) de los actantes. Esto a su vez refuerza su capacidad para traducir o para lograr adhesión discursiva, es decir para hablar en nombre de otros o para hacer hablar a otros en nombre de uno". ${ }^{429}$ En otras palabras,

"la prueba" es el momento en que se pone en evidencia el triunfo o el fracaso de la controversia, “(...) en donde la fuerza de la adhesión construye retóricas o traducciones que refuerzan su capacidad para hablar y anulan las capacidades de otros". ${ }^{430}$

Podemos identificar diferentes "pruebas" en las que se definen las controversias planteadas por los anarquistas.

En primer lugar, identificamos las elecciones presidenciales de 1951 como la "prueba" a partir de la cual era posible evaluar la injerencia de la discursividad libertaria en torno al voto femenino y su ciudadanía política. Según Dora Barrancos, el apoyo de las mujeres al peronismo le dio a este gran parte de su fuerza. ${ }^{431}$ Sea por la figura de Eva Perón o por el fuerte anclaje popular que tuvo el movimiento (confirmado por el apoyo generalizado que obtuvo en las elecciones presidenciales de 1951), lo cierto es que sin dudas el peronismo (como movimiento político y social y como partido gobernante) se instala sosteniendo algunas de las banderas de lucha que hasta ese momento eran sostenidas por los movimientos (como el feminista) y partidos de izquierda.

En relación al apoyo masivo que logra por parte de las mujeres, la sanción de la ley 13.010 que les otorga los derechos políticos, sin duda, se instala en el imaginario de la época como una concesión del estado peronista (por medio de Eva

\footnotetext{
${ }^{429}$ Nardacchione, Gabriel (2011). “El conocimiento científico...”, op. cit. Pág. 180.

${ }^{430}$ Ibídem.

${ }^{431}$ Barrancos, Dora (2007). Mujeres en la sociedad Argentina. .., op. cit. 
Perón) a las mujeres de las clases populares. ${ }^{432}$ De este modo, el apoyo casi generalizado de las mujeres en las elecciones presidenciales de 1951 (el $64 \%$ vota por el Partido Justicialista) significó para el resto de las fuerzas políticas de izquierda, entre las que encontramos al anarquismo, la naturaleza conservadora de las mujeres y la manipulación de ese derecho otorgado por parte de un estado con fines totalitarios. En ninguna de sus publicaciones o acciones dan cuenta de que existan portavoces que les estén indicando que lograron el interesamiento. Podemos pensar que están hablando a mujeres que no entienden esta problematización, no se sienten interpeladas por ella, que se encuentran cercanas a otras entidades. En otras palabras, es el fallo de la prueba.

Haya sido por medios demagógicos, por medio de la corrupción, las dádivas o el engaño (según las interpretaciones anarquistas que hemos analizado), lo cierto es que el peronismo no sólo obtiene el apoyo de la mayor parte de la población en las elecciones de 1946 y 1951, sino que los niveles de sindicalización de la masa trabajadora en los sindicatos que se encuentran bajo la órbita de la CGT aumentan considerablemente en comparación con los niveles existentes a comienzos de la década de $1940 .{ }^{433} \mathrm{Si}$ bien, como hemos demostrado, desde los periódicos libertarios se publicitan las acciones de oposición y de lucha de los sindicatos y organizaciones obreras opuestas a la CGT y al peronismo, la escasez de militantes orgánicos a la FACA o las USL en las organizaciones base, dan cuenta de un escaso poder de movilización. A lo largo del año 1952, Acción Libertaria sostiene que la pasividad del apoyo al peronismo por parte de los sectores obreros se sostiene porque la CGT funciona como una "policía política". ${ }^{434}$ Esto implica que cuanto mayor es la presión y la persecución (por parte de algunos referentes de la CGT) sobre los militantes sindicales que proponen alternativas de acción política, más adeptos logran encauzar bajo sus filas. Así como vislumbramos que para los

\footnotetext{
${ }^{432}$ Barrancos y Valobra aseguran de que si bien el Partido Socialista como el Partido Comunista de la Argentina apoyaron el otorgamiento de los derechos políticos a las mujeres, ambas tendencias intentaron dar cuenta de sus luchas previas en la consecución de este derecho. El anarquismo también reconoce, en el año 1951, que parte del éxito del peronismo puede explicarse por haber retomado los reclamos que históricamente eran bandera del anarquismo como ser "el derecho a un trabajo digno", la justa retribución del mismo y seguridad social para todos los trabajadores. A.L., $N^{o}$ 135, mayo de 1952.

${ }^{433}$ Sidicaro, Ricardo (1999): "Consideraciones sociológicas sobre las relaciones entre el peronismo y clase obrera en la Argentina, 1943-1955", en Mackinon, Moria y Petrone, M. (comp.). Populismo y neopopulismo en América Latina. El problema de la Cenicienta, Buenos Aires, Eudeba. Mora y Araujo, M. y Llorente, I. (1980) (comps.). El voto peronista, Buenos Aires, Editorial Sudamericana. ${ }^{434}$ A.L., $\mathrm{N}^{\mathrm{o}} 137$, agosto de 1952.
} 
colectivos libertarios el voto de las mujeres significaba una herramienta posiblemente liberadora (a pesar de los resultados), la participación activa de los trabajadores en la vida sindical es vista ahora como el triunfo del totalitarismo, ya que esa participación se da en los espacios propuestos y habilitados por el peronismo en el gobierno y la CGT.

Resulta complejo identificar el momento en que el fallo de la prueba define el fracaso de la controversia con respecto a los sujetos universitarios. Entre los años 1946-1947, la mayoría de los docentes e investigadores y militantes anarquistas que participaban intensamente en la vida universitaria son removidos de sus cargos y el movimiento estudiantil universitario se encuentra públicamente en las antípodas del peronismo. Sin embargo, como han analizado en profundidad varios autores, fueron muchos más los docentes, científicos y técnicos que permanecen en sus lugares de trabajo en la universidad y los institutos. ${ }^{435}$ Así como hemos visibilizado agrupaciones de profesionales y de científicos que presentan acciones de resistencia frente a situaciones puntuales, como son la expulsión de médicos en un hospital público de Santa Fe o la necesidad de encauzar el uso de la energía atómica para fines de paz por parte de los científicos, lo cierto es que para el año 1951 no hay registros de acciones mancomunadas de estas agrupaciones que sí aparecen en 1946. Los registros dejan en claro que sólo algunas agrupaciones como Acción Laica de la Argentina (en la cual participan algunos miembros del movimiento libertario como Juan Lazarte) aún sostienen cierto nivel de actividad.

En relación a los colectivos estudiantiles, tomamos el caso de Floreal Ferrara como ejemplo de los desafíos que el peronismo planteó a las identidades anarquistas. Recordemos que, en el año 1946, Ferrara era estudiante de la carrera de medicina en la Universidad de La Plata. Participa activamente como corresponsal de la prensa libertaria (Reconstruir, R.A.E y Acción Libertaria) en los temas

\footnotetext{
${ }^{435}$ Germán Soprano ha analizado las trayectorias universitarias en la Facultad de Ciencias Naturales de la Universidad de La Plata entre 1935 y 1955. En su estudio, concluye que más que por cuestiones ideológicas o políticas, los desplazamientos y cambies en las cátedras tienen distintas causas:" Muertes, jubilaciones, retiros alianzas y rivalidades entre pares, procesos de crecimiento en las carreras académicas y profesionales, relevos generacionales, relaciones entre maestros y discípulos, tuvieron una eficacia en la reproducción de la vida universitaria en períodos políticamente conflictivos como los años comprendidos entre 1930 y 1955, al punto que no sería desacertado observar que las políticas estatales y la política nacional sólo consiguieron desplazar las primeras determinaciones del centro de la vida académica cotidiana en circunstancias acotadas, como en las intervenciones a la universidad de los años 1946 y 1955". Soprano, Germán (2009b). "Autonomía universitaria e intervención política en la trayectoria de liderazgos y grupos académicos en Ciencias Naturales de la Universidad Nacional de La Plata 1930-1955", en Anuario del Instituto de Historia Argentina. (9) pp. 97-147.
} 
relacionados con el mundo universitario. Al mismo tiempo es presidente del Centro de Estudiantes, por una lista que según sus palabras, se enfrenta a los comunistas y a los radicales. ${ }^{436}$ En su relato, reconoce que la personalidad y las ideas de Ramón Carrillo sobre la salud modifican rotundamente su perspectiva política y de acción. ${ }^{437} \mathrm{Si}$ bien no refiere a su activa participación en los colectivos libertarios, para el 1951 y siendo médico recibido instalado en una zona suburbana-rural del Gran La Plata, se autodefine como referente peronista en su barrio. Ferrara considera al peronismo como un fenómeno político que se basa en el empoderamiento de los sectores postergados, para quienes la salud es una herramienta de transformación social. Esos aspectos del peronismo posiblemente se articulan con sus inquietudes sociales y políticas, en algunos aspectos emparentados con las ideas libertarias. Podríamos resumir que en el caso de los estudiantes universitarios, algunos aspectos de la política peronista pudieron haber influido para que su activa participación opositora se transforme en un "acomodamiento" en cuanto a alejarse de la militancia antiperonista y comenzar a desempeñarse profesionalmente en el ámbito de la salud, la administración pública o en sus profesiones de manera independiente.

"Los actores implicados no reconocen sus papeles en la historia ni la paulatina deriva en la que debían participar, en su opinión, con absoluta fidelidad. Como dice el aforismo, traductor, traidor. De la traducción a la traición sólo hay un corto paso. Es el paso que se da en la última fase (...)". ${ }^{476}$

Resta una reflexión general, sobre la incumbencia o no de investigar a un colectivo que quizá nunca contó con un apoyo masivo y que por esta misma característica fue invisibilizado por la historiografía, pero también por sus contemporáneos. Durante el proceso en el que identificamos las agencias libertarias, en los años en que hemos centrado nuestra investigación, es posible ver a los anarquistas actuando de manera organizada y con propuestas novedosas. Como avizoramos en el Capítulo 2, gran parte de esta historia puede explicarse a partir del seguimiento de las trayectorias biográficas. Sin embargo, la suma de los ímpetus

\footnotetext{
${ }^{436}$ Svampa, Maristella (2011). Certezas, incertezas y desmesuras...op. cit.

${ }^{437}$ Por tener amigos en común, Ferrara conoce personalmente a Carrillo alrededor del año 1950. En ocasión de sus encuentros, Ferrara relata: "En un momento determinado, él me cuenta, "Mire, una de las grandes peleas con Eva era que yo creo que el Estado es el responsable de la salud y como
} 
individuales no implica la resolución del complejo problema de la movilización política y de la identificación (identidad) colectiva.

tal, todos los directores de los hospitales y de todos los establecimientos tienen que ser represen tantes del Estado”. Y Eva le peleaba, le decía que los hospitales son del pueblo y, como tal, los tiene que manejar el pueblo. “¿Y usted que piensa?”, me preguntó Carrillo. Y me miraba el negro, y yo lo miraba todo achicadito (risas). Yo tendría 28, 29 años y le dije: "Me parece que Eva tenía razón". "No ve, son todos revolucionarios... pero tienen razón”. Ibídem, Pág. 30. De esta manera, Ferrara repara en la figura de Eva Perón y sus ideas con respecto al poder del pueblo y la medicina como herramienta popular para promover el cambio social.

${ }^{476}$ Callon, Michelle (1986). "Some elements...", op. cit. s/n

Por último, haber abordado fuentes que habían permanecido ocultas a los ojos de los historiadores del anarquismo y comprobar que las agencias libertarias no se agotan con la llegada del peronismo sino que más bien retoman visibilidad pública en los años posteriores a 1955, nos permite aventurar que en los próximos años estaremos recibiendo nuevos trabajos con nuevas miradas para reinterpretar (una vez más) la historia del anarquismo en la Argentina. 


\section{FUENTES}

\section{Publicaciones periódicas}

- Avanzada. Revista de las Juventudes Socialistas de Buenos Aires (1941).

- Avanzada! Bahía Blanca (1944)

- Ateneo, boletín del Ateneo Ciudad de Avellaneda (1951).

- Compañero!, órgano de la agrupación Juvenilia de Rosario desde 1951.

- De Pie! Órgano de la Agrupación Estudiantil Anarquista. Noviembre (1946)

- Documentos Históricos de España, Año 1, No 4, España. (1938)

- $\quad$ Mujeres Libres. № 1, 2, 3, 4. España (1936)

- Rebeldía, Portavoz del Grupo Independiente, Cuadro 9 , Cárcel de Villa Devoto (1954)

- Unión Obrera Local. Periódico de la Unión Obrera Local de Mar del Plata, (1946).

Acción Libertaria

- A. L. No 38, octubre de 1940.

- A. L., $\mathrm{N}^{\mathrm{o}} 40$, diciembre de 1940.

- A. L., $\mathrm{N}^{\mathrm{o}} 41$ enero de 1941.

- A. L., $\mathrm{N}^{\circ} 42$, febrero de 1941.

- A.L, $\mathrm{N}^{\mathrm{o}} 48$, septiembre de 1941.

- A. L., $\mathrm{N}^{\mathrm{o}} 46,1943$.

- A.L., $\mathrm{N}^{\circ} 63$, marzo de 1943.

- A.L., $\mathrm{N}^{\mathrm{o}} 67$, agosto de 1943.

- A.L., $\mathrm{N}^{\circ} 84$, marzo de 1945.

- $\quad A . L, \mathrm{~N}^{\circ} 98$, mayo de 1947.

- A.L, $\mathrm{N}^{\circ} 106$, Mayo de 1948. $\square$ A.L. $\mathrm{N}^{0} 111$, febrero de $1949 \square$ A.L. $\mathrm{N}^{0} 115$, julio de 1949 .

- A.L. $\mathrm{N}^{\mathrm{o}}$ 129, mayo de 1951. 
- A.L., $N^{o} 135$, mayo de 1952

- A.L. N $\mathrm{N}^{\circ} 137$, agosto de 1952.

- A.L., $\mathrm{N}^{\mathrm{o}} 138$, febrero de 1953.

\section{Reconstruir}

- Reconstruir, $\mathrm{N}^{\circ}$ 1, junio de 1946.

- Reconstruir, $\mathrm{N}^{\mathrm{o}}$ 2, julio de 1946.

- Reconstruir, $\mathrm{N}^{\mathrm{o}}$ 3, julio de 1946.

- Reconstruir, № 4, agosto de 1946.

- Reconstruir, № 5, agosto de 1946.

- Reconstruir, № 6, Septiembre de 1946.

- Reconstruir, $\mathrm{N}^{\mathrm{0}}$ 7, septiembre de 1946.

- Reconstruir, No 8, octubre de 1946.

- Reconstruir, № 9, noviembre de 1946.

- Reconstruir, $\mathrm{N}^{\circ}$ 10, diciembre de 1946.

- Reconstruir, № 11, enero de 1947.

- Reconstruir, $\mathrm{N}^{\circ} 12$, febrero de 1947.

- Reconstruir, $\mathrm{N}^{\circ}$ 13, marzo de 1947.

- Reconstruir, No 14, abril de 1947.

- Reconstruir, № 15, mayo de 1947.

- Reconstruir, № 16, junio de 1947.

- Reconstruir, No 17, julio de 1947.

- Reconstruir, № 18, agosto de 1947.

- Reconstruir, $\mathrm{N}^{\circ}$ 19, agosto de 1947.

- Reconstruir, № 20, septiembre de 1947.

- Reconstruir, $\mathrm{N}^{\circ} 21$, octubre de 1947.

- Reconstruir, $\mathrm{N}^{\circ}$ 22, noviembre de 1947.

- Reconstruir, № 23, noviembre de 1947.

- Reconstruir, № 48, mayo de 1950.

- Reconstruir, $\mathrm{N}^{\circ}$ 51, septiembre de 1950.

- Reconstruir, № 52, octubre de 1950.

- Reconstruir, $\mathrm{N}^{\mathrm{0}}$ 53, diciembre de 1950.

- Reconstruir, № 54, mayo de 1951.

- Reconstruir, № 55, julio de 1951.

- Reconstruir, № 56, septiembre de 1951. 
- Reconstruir, $\mathrm{N}^{\circ}$ 57, diciembre de 1951.

- Reconstruir, $\mathrm{N}^{\mathrm{0}}$ 58, abril de 1952.

- Reconstruir, $\mathrm{N}^{\mathrm{o}}$ 59, agosto de 1952.

- Reconstruir, № 60, noviembre de 1952.

\section{Documentos orgánicos, manifiestos, panfletos.}

- A.P. (1951). "La mujer en la lucha social". Informe presentado por AnaPiacenza para ser leído en el Tercer Congreso Ordinario de la FACA.

- Carta de Diego abad de Santillán a la Comisión Directiva de la USL de Capital Federal, en Unión Socialista Libertaria de Buenos Aires (1949). "Carta ad referéndum", s/d

- Archivo DIPBA, Mesa C, Carpeta 1, Legajo No 25.

- Agrupación Femenina Antiguerrera (1936). La mujer argentina y sus derechos. Buenos Aires

- "Pacto de Solidaridad aprobado por la FORA", (1904)

- "Manifiesto al Proletariado del país". Comisión Obrera de Relaciones Sindicales (CORS). (1941)

- Acción Libertaria. Órgano de la FACA. Boletín $N^{\circ} 1$. Buenos Aires, (1944)

- Boletín FACA. (1944)

- Boletín de la FACA. (1951)

- FACA, Sección Rosario. (1944)

- J. J. L. L. de Argentina. Boletín de las Juventudes Libertarias, $\mathrm{N}^{\circ}$ 3. Buenos Aires, octubre. (1939)

- "Lucha constructiva por la libertad y la justicia social. Posición del movimiento libertario ante la actual situación mundial y argentina. Ediciones FACA, Buenos Aires (1944)

- Carta de la Federación Anarco Comunista Provincial de Buenos Aires al Secretario del Comité Nacional, noviembre (1940).

- Acción Libertaria. Órgano de la FACA. Boletín № 1. Buenos Aires, enero (1944).

- Boletín FACA (1944)

- Boletín de la FACA (1951) F.A.C.A, 1944.

Panfleto

- “Declaración de principios", USL de Capital Federal (1946)

- Unión Socialista Libertaria, Capital Federal, (1948)

- "Resoluciones aprobadas en el Congreso Constituyente de la Federación AnarcoComunista.", FACA (1935)

- "Memoria y Balance", Unión Socialista Libertaria de Buenos Aires. (1948)

\section{Fuentes bibliográficas}


- Berdichevsky, L; Inglese, J.; Yegros Doria, C. (1965). Universidad y estudiantes. Universidad y peronismo. Buenos Aires, Libera

- Ghioldi, Américo (1956). De la tiranía a la democracia social. Buenos Aires, Gure.

- Grunfeld, José y Jacinto Cimazo (1981). Luis Danussi, en el movimiento social y obrero argentino. 1938-1978. Buenos Aires, Proyección.

- Grunfeld, José (2000). Memorias de un anarquista. Buenos Aires, Nuevo Hacer.

- Lazarte, Juan (1932). Revolución sexual de Nuestro Tiempo. Buenos Aires, Nervio.

- Lazarte, Juan (1935 a). Lineas y trayectorias de la Reforma Universitaria. Rosario, Editorial Ruiz.

- Lazarte, Juan (1935 b). Sociedad y prostitución. Rosario, Librería Ruiz.

- Lazarte, Juan (1936). Contralor de los nacimientos. Rosario, Librería Ruiz.

- Lazarte, J. (1958). Federalismo y descentralización en la cultura argentina. Rosario, Cátedra Lisandro de la Torre.

- Lunazzi, José María (1946). "Discurso pronunciado en acto por el día del estudiante en las puertas de la Universidad de LA Plata, 21 de septiembre de 1945”. Revista Americana de Educación, No 2. s/n.

- Lunazzi, José María (1979). Futurología del taller y de la escuela. La Plata: Ediciones R.A.E.

- Marianetti, Benito (1950). Nosotros y la constitución. Mendoza, D’Accurzio.

- Martínez Civelli, Aquiles (1943). Las Usinas eléctricas populares y cooperativas eléctricas en la República Argentina. Resultados de su funcionamiento. La Plata: Universidad Nacional de La Plata. S/n

- Martínez Civelli, Aquiles (1945). "Discurso pronunciado por el Señor Vicepresidente de la Universidad Ing. Aquiles Martínez Civelli, en el acto de reapertura de la Universidad, el dia 25 de octubre de 1945", en Publicaciones de la Facultad de Ciencias Físicomatemáticas. Serie Tercera, $N^{\circ} 32$. Publicaciones especiales de la UNLP, La Plata.

- Mella, Ricardo (1909). "La lucha de clases", en Tribuna Libre, núm. 3. Gijón, 8 mayo.

- Nita Nahuel (1936) "Fascistas en rojo y negro”, en Mujeres Libres, № 1, pág. 12 Pavón, Iris (1952). Pasión de Justicia. Buenos Aires, Editorial Reconstruir. 


\section{Bibliografía}

1. AAVV (2005). Catálogo de publicaciones anarquistas, s/d.

2. Abad de Santillán, Diego, Invaldi, Ángel y Capelletti, Ángel (1964). Juan Lazarte, militante social, médico, humanista. Rosario, Grupo Editor de Estudios Sociales.

3. Abós, Álvaro (2011). "La Venus Roja”, en Todo es Historia, № 408.

4. Acha, Omar (2004). "Sociedad civil y sociedad política durante el primer peronismo", en Desarrollo económico, 199-230.

5. Acha, Omar (2009), Historiografia crítica de la historiografía argentina: las izquierdas en el siglo XX, vol. 1. Buenos Aires, Prometeo.

6. Acha, Omar y Quiroga, Nicolás (2009). "La normalización del primer peronismo en la historiografía argentina reciente", en EIAL: Estudios Interdisciplinarios de America Latina y el Caribe, $\mathrm{N}^{\mathrm{o}}$ 20, 7-34.

7. Acosta, María Teresa (2012), "Políticas de maternidad durante el período peronista: quiebres y continuidades en las relaciones de género." Trabajo de Especialización, Maestría en Ciencias Sociales y Humanidades, con mención en Historia. Inédito.

8. Acri, Martín A. y Cázeres María del C. (2011). La educación libertaria en la Argentina y en México. 1861-1945. Libros de Anarres, Buenos Aires.

9. Almaraz, Roberto; Corchon, Manuel y Zemborain, Rómulo (2001) ;Aqui FUBA! Las luchas estudiantiles en tiempos de Perón (1943-1955). Buenos Aires, Planeta.

10. Altamirano, Carlos (2001). Peronismo y cultura de izquierda. Buenos Aires, Temas.

11. Amorós, Celia (1994) Historia de la teoría feminista. Instituto de investigaciones feministas de la Universidad Complutense de Madrid.

12. Anapios, Luciana (2008 a) "Compañeros, adversarios y enemigos. Conflictos internos en el anarquismo argentino en la década del '20", en Entrepasados, № 31.

13. Anapios, Luciana (2008 b). "El anarquismo argentino en los años 20. Tres momentos en el conflicto entre La protesta y La Antorcha", en Papeles de trabajo. Revista electrónica del Instituto de Altos Estudios Sociales de la Universidad Nacional de General San Martín. ISSN: 1851-2577. Año 2, nº 3, Buenos Aires, junio.

14. Anapios, Luciana (2011). "Una promesa de folletos. El rol de la prensa en el movimiento anarquista en la Argentina (1890-1930)", en A contracorriente. Una revista de historia social y literatura en América Latina. Vol. 8, No. 2, Winter. www.ncsu.edu/project/acontracorriente.,

15. Andrés Granel, Elena (2006). "Mujeres Libres: emancipación femenina y revolución social", en Germinal. Revista de Estudios libertarios, № 2 .

16. Ansaldi, Waldo (1993). "Cosecha roja. La conflictividad obrero-rural en la región pampeana, 1900-1937", en Ansaldi, Waldo (comp.). Conflictos obrero-rurales pampeano. 1900-1937. Buenos Aires, CEAL.

17. Archetti, Eduardo (1977). "El proceso de capitalización de campesinos argentinos", en Cahiers du monde hispanique et luso-brésilien, 28(1), 123-140. 
18. Ardanaz, Eleonora (2007). Madres de rojo y negro: cambios en las representaciones acerca de la maternidad en el discurso anarquista argentino. II Jornadas Hum. H. A. Bahía Blanca 4 al 16 de octubre. http://www.jornadashumha.com.ar/pdf/2007/Ardanaz.pdf.

19. Ascolani, Adrián (2009). El sindicalismo rural en la Argentina: de la resistencia clasista a la comunidad organizada, 1928-1952. Universidad Nacional de Quilmes.

20. Avni, Haim (1986) La inmigración judía en la Argentina. Buenos Aires, Editorial AMIA.

21. Bacci, Claudia y Fernández Cordero (2007). "Feroces de lengua y pluma. Sobre algunas escrituras de mujeres anarquistas", en Políticas de la Memoria, núm. 6/7.

22. Baily, Samuel (1985). Movimiento obrero, nacionalismo y política en Argentina. Buenos Aires, Hyspamerica.

23. Barletta, Ana (2002). "Una izquierda universitaria peronista. Entre la demanda académica y la demanda política (1968-1973)", en Prismas. Revista de Historia Intelectual, 6, 275-286.

24. Barrancos, Dora (1990a). Anarquismo, educación y costumbres en la Argentina de principios de siglo, Buenos Aires, Contrapunto.

25. Barrancos, Dora (1990 b). "Anarquismo y sexualidad"; en Armus, Diego (comp). Mundo urbano y cultura popular. Buenos Aires, Sudamericana.

26. Barrancos, Dora (1991). Educación, cultura y trabajadores:(1890-1930) (Vol. 331). Buenos Aires, Centro Editor de America Latina SA.

27. Barrancos, Dora (1996a) "Mujeres de Nuestra Tribuna: el difícil oficio de la diferencia”, en Mora. Revista del Área Interdisciplinaria de Estudios de la Mujer, $\mathrm{N}^{\circ} 2$. UBA, Buenos Aires.

28. Barrancos, Dora (1996b). La escena iluminada. Ciencia para trabajadores, Buenos Aires, Plus Ultra.

29. Barrancos, Dora (2002), "Iniciativas y debates en materia de reproducción durante el primer peronismo (1946-1952)" en Seposal, Salta.

30. Barrancos, Dora (2007). Mujeres en la Sociedad Argentina. Una historia de cinco siglos. Buenos Aires, Sudamericana.

31. Barrancos, Dora (2008). Mujeres, entre la casa y la plaza. Buenos Aires, Sudamericana.

32. Barrancos, Dora (2011) "El Partido Socialista y el sufragio femenino, 1947-1951", en Barry, Carolina (comp.), Sufragio femenino. Prácticas y debates políticos, religiosos y culturales en Argentina y América Latina. EDUNTREF.

33. Barrancos, Dora (2011). "El Partido Socialista y el sufragio femenino, 19471951", Barry, Carolina (comp.). Sufragio femenino. . Prácticas y debates políticos, religiosos y culturales en Argentina y América Latina. Buenos Aires, EDUNTREF.

34. Barrandeguy, Emma (1997). Salvadora. Una mujer de Crítica. Buenos Aires, Vinciguerra.

35. Barreneche, Osvaldo (2007). La reforma policial del peronismo en la provincia de Buenos Aires, 1946-1951. Desarrollo económico, Vol 47, Nº 186.

36. Barreneche, Osvaldo (2010). "La policía de la provincia de Buenos Aires durante la primera mitad del siglo XX”, en Cuadernos de Antropología Social No 32. 
37. Barry, Carolina (2009) Evita capitana: el Partido Peronista Femenino, 19491955. EDUNTREF, Editorial de la Universidad Nacional de Tres de Febrero.

38. Barry, Carolina (comp.) (2011). Sufragio femenino. Prácticas y debates políticos, religiosos y culturales en Argentina y América Latina. Buenos Aires, EDUNTREF.

39. Bayer, Osvaldo (1970). Severino Di Giovanni, el idealista de la violencia. Buenos Aires, Editorial Galerna.

40. Bayer, Osvaldo (1972). La Patagonia rebelde (tomos I y II). Buenos Aires, Editorial Galerna.

41. Bayer, Osvaldo (1974). La Patagonia rebelde (tomo III). Buenos Aires, Editorial Galerna.

42. Bayer, Osvaldo (1975). Los anarquistas expropiadores y otros ensayos. Editorial Galerna, Buenos Aires.

43. Bayer, Osvaldo (2007). Los anarquistas expropiadores y otros ensayos. Buenos Aires, Planeta.

44. Belkin, Alejandro (2006). Sobre los orígenes del sindicalismo revolucionario en Argentina, Buenos Aires, Ediciones del Centro Cultural de la Cooperación Floreal Gorini. 45. Bellucci, Mabel (1990). "Anarquismo, sexualidad y emancipación femenina. Argentina alrededor del 900", en Nueva Sociedad, N 109, septiembre-octubre.

46. Bellucci, Mabel (s/d) "Anarquismo y feminismo: el movimiento de mujeres anarquistas con sus logros y desafíos hacia principios de siglo http://www.nodo50.org/mujerescreativas/mabel_bellucci.htm

47. Bellucci, Mabel y Camusso, Cristina (1987) "La huelga de inquilinos de 1907. El papel de las mujeres anarquistas en la lucha", en Cuadernos del CICSO, serie Estudios, $\mathrm{N}^{\circ} 58$.

48. Benyo, Javier (2005). La Alianza Obrera Spartacus. Anarquismo, vanguardia obrera e institucionalización del movimiento sindical en la década de 1930, Buenos Aires, Libros de Anarres.

49. Berdichevsky, León; Inglese, José; Yegros Doria, Carlos (1965). Universidad y estudiantes. Universidad y peronismo. Buenos Aires, Libera.

50. Bianchi, Susana (2000). "Las mujeres en el peronismo (Argentina 1945-1955)", en: Duby, G., y Perrot. M. (dir.) Historia de las Mujeres, El siglo XX, Madrid, Taurus.

51. Bianchi, Susana y Sanchís, Norma (1988). El Partido Peronista Femenino. Buenos Aires, Centro editor de América latina.

52. Bibiloni, A.G. (2007). "La Física en La Plata, del justicialismo al desarrollismo pasando por "la en http://anales.fisica.org.ar/journal/index.php/analesafa/article/viewFile/214/235.

53. Biernat, Carolina y Ramacciotti, Karina (2011). "La protección a la maternidad de las trabajadoras en Argentina: aspectos legales y administrativos en la primera mitad del siglo XX”, en Hist. ciênc. saúde-Manguinhos, 18 (supl. 1), 153-177.

54. Bilsky, E., Trajtenberg, G. y Weinstein, A. E. (1987). El movimiento obrero judio en la Argentina (Vol. 4). AMIA/Editorial Milá.

55. Bisso, Andrés (2002). "De Acción Argentina a la Unión Democrática", en Prismas. Revista de historia intelectual, (6), 257-264. 
56. Bisso, Andrés (2005). Acción Argentina: un antifascismo nacional en tiempos de Guerra Nacional: Acción Argentina y las estrategias de movilización del antifascismo liberal-socialista en torno a la Segunda Guerra Mundial (1940-1946). Prometeo Libros.

57. Bisso, Andrés (2009). Sociabilidad, política y movilización: cuatro recorridos bonaerenses 1932-1943. Buenos Aires, Buenos Libros.

58. Bjerg, María (2009). Historias de la inmigración en la Argentina. Buenos Aires, Edhasa.

59. Bonaudo, Martha y Godoy, M. (1985). "Una corporación y su inserción en el proyecto agro-exportador: la Federación Agraria Argentina, (1912-1933)" en Anuario, $\mathrm{N}^{\circ}$ 11, Facultad de Humanidades y Artes, Universidad Nacional de Rosario.

60. Borda, Ángel (1987). Perfil de un libertario. Cuentos, narraciones y poesías del litoral. Historia Sindical de Entre Ríos. Buenos Aires, Editorial Reconstruir.

61. Bordagaray, María Eugenia (2011a) "La anarquistas argentinas y el voto femenino (1946-1955), en Barry, Carolina (comp.). Sufragio femenino. Prácticas y debates políticos, religiosos y culturales en Argentina y América Latina. Buenos Aires, EDUNTRF.

62. Bordagaray, María Eugenia (2011b). “Anarquismo en la Argentina. Repertorios organizacionales y de acción colectiva en el movimiento libertario, 1935-1955", en Repertorio Americano, Segunda Nueva Época, volumen 21, Costa Rica, octubre.

63. Bordagaray, María Eugenia (2012). "Anarquismo y movimiento universitario en Argentina, 1935-1950" Revista CS, Nº. Universidad de Cali.

64. Bourdieu, Pierre (1991). "Estructuras, habitus, prácticas", en El sentido práctico, Madrid, Taurus.

65. Bourdieu, Pierre (2005). "La ilusión biográfica" en Archipiélago: Cuadernos de crítica de la cultura, $\mathrm{N}^{\mathrm{o}} 69,87-96$.

66. Bracamonte, Lucía (2006). "Anarquismo y cuestión femenina. Una visión sobre lo público y lo privado en la prensa de Bahía Blanca a principios del siglo XX", en el@tina, Revista electrónica de estudios latinoamericanos, Unidad de Docencia e Investigaciones Sociohistóricas de América Latina (UDISHAL), Vol. 4, No 16, Facultad de Ciencias Sociales, Universidad de Buenos Aires, Argentina, Buenos Aires, julioseptiembre.

67. Caimari, Lila (1995). Perón y la Iglesia Católica: religión, estado y sociedad en la Argentina, 1943-1955. Ariel, Buenos Aires.

68. Califfa, Juan Sebastián (2010). "La militancia estudiantil en la Universidad de Buenos Aires entre golpe y golpe, 1943-1955". En Buchbinder, P.; Califa, J. y Millán, M. Apuntes sobre la formación del movimiento estudiantil argentino 1943-1973. . 69. Callon, M., y Latour, B. (1981). "Unscrewing the big Leviathan: how actors macrostructure reality and how sociologists help them to do so.", en AAVV, Advances in social theory and methodology: toward an integration of microand macrosociologies, 277-303.

70. Callon, Michelle (1986). "Some Elements of a Sociology of Translation: Domestication of theScallope and the Fishermen of St Brieuc Bay", en Law, J. (ed.). Power, action and Belief: A New Sociology of Knowledge? London, R.K.P.

71. Callon, Michelle (1986). The sociology of an actor-network: The case of the electric vehicle. Mapping the dynamics of science and technology.

72. Callon, Michelle, y Latour, Bruno. (1992). "Don't throw the baby out with the bath school! A reply to Collins and Yearley". Science as practice and culture. 
73. Calzetta, Elsa (2005) "Juana Rouco Buela, una mujer anarquista", en Nuestra Tribuna. Hojita del sentir anárquico femenino (1922-1925), Bahía Blanca, EDIUNS.

74. Calzetta, Elsa (2005). Nuestra tribuna: Hojita sentir anárquico femenino, 1922-1925. Editorial de la Universidad Nacional del Sur.

75. Camarero, Hernán (2005). "La izquierda como objeto historiográfico. Un balance de los estudios sobre el socialismo y el comunismo en la Argentina", en Nuevo Topo. Revista de historia y pensamiento crítico. $\mathrm{N}^{\mathrm{o}} 1$.

76. Camarero, Hernán (2007). A la conquista de la clase obrera. Los comunistas y el mundo del trabajo en la Argentina, 1920-1935. Buenos Aires, Siglo XXI.

77. Camarero, Hernán y Herrera, Carlos (2005). El Partido Socialista en Argentina: Sociedad, política e ideas a través de un siglo. Buenos Aires, Prometeo.

78. Campione, Daniel (2003). Prolegómenos del peronismo. Los cambios en el Estado nacional, 1943-1946. Buenos Aires, FISyP, Manuel Suárez.

79. Campos, Luis (2009). "Estado y sindicatos: un análisis de sus relaciones a partir de los mecanismos de regulación y la conformación de la estructura sindical en Argentina (1943 - 1988)" (mimeo).

80. Capel, Rosa María (1975). El sufragio femenino en la Segunda República Española, Granada, Universidad de Granada.

81. Capelleti, Angel (1990). El anarquismo en América latina. C. M. Rama (Ed.). Fundacion Biblioteca Ayacucho.

82. Carli, Sandra (1998). "Infancia, política y educación en el peronismo: de los derechos del niño a las vanguardias políticas del futuro." Anuario de historia a de la educación, $\mathrm{N}^{\mathrm{0}} 2$.

83. Carli, Sandra (2002). Niñez, pedagogía y política: transformaciones de los discursos acerca de la infancia en la historia de la educación argentina entre 1880 y 1955. Miño y Dávila.

84. Cefai, Daniel (2011), "Diez propuestas para el estudio de las movilizaciones colectivas. De la experiencia al compromiso" en Revista de Sociología, № 26, pp. 137166 .

85. Cerri, Chiara (2010) "La subjetividad del Género. El sujeto sexuado entre individualidad y colectividad", en Gazeta de Antropología, $\mathrm{N}^{\mathrm{o}} 26$. http://www.ugr.es/ ppwlac/G26 42Chiara_Cerri.pdf)

86. Ceruso, Diego (2011). "El trabajo sindical de base del anarquismo argentino: la FACA y la Alianza Obrera Spartacus", en A Contra corriente. Una revista de historia $\begin{array}{llllll}\text { social } y \text { literatura de América Latina. Vol } 8, & \mathrm{~N}^{\circ}\end{array}$ 3. www.ncsu.edu/project/acontracorriente.

87. Ceruso, Diego (2012). "La izquierda y la organización sindical en el lugar de trabajo, 1920-1940", en Revista Archivos del Historia del Movimiento Obrero y la Izquierda, $\mathrm{N}^{\mathrm{o}} 1$.

88. Cesano, José Daniel (2010). Inmigración, anarquismo y sistema penal. Los discursos expertos y la prensa Córdoba y Buenos Aires 1890 - 1910 (Protesta social, flujos migratorios y criminalización). Buenos Aires, Editorial Alción.

89. Ciria, Alberto. y Sanguinetti, Horacio (1968). Los Reformistas. Buenos Aires, Jorge Álvarez. 
90. Ciria, Alberto. (1983). Política y cultura popular: la Argentina peronista, 19461955. Buenos Aires, Ediciones de la Flor.

91. Contreras, Nicolás (2008). "Clase obrera y peronismo. La "gran" huelga marítima de 1950", Ponencia presentada en XXI Jornadas de Historia Económica. Asociación Argentina de Historia Económica. Universidad Nacional de Tres de Febrero. Caseros (Buenos Aires), 23 al 26 de septiembre.

92. Contreras, Nicolás (2007). "De todos modos las rotativas pararon. La huelga de obreros gráficos de 1949". Ponencia presentada en I o Jornadas de Jóvenes Investigadores. Universidad Nacional de Mar del Plata, 31 de mayo y 1 de junio. Disponible en http://historiapolitica.com/datos/biblioteca/contreras1.pdf.

93. Corcuff, Philipe (1998). Las nuevas sociologías. Construcciones de la realidad social. Madrid, Alianza Editorial.

94. Cucuzza, H. R. y Acevedo, C. (1997). Estudios de historia de la educación durante el primer peronismo,

95. Cucuzza, Héctor (1996). Historia de la Educación en debate; Bs. As. Miño y Dávila.

96. D’ Antonio, Débora (2000) "Representaciones de género en la huelga de la construcción, Buenos Aires, 1935-36", en Fernanda Gil Lozano (et.al.)(comps.). Historia de las Mujeres en la Argentina, Siglo XX. Buenos Aires, Taurus.

97. De la Rosa, María Fernanda (2012). Diego Abad de Santillán. Una utopía en rojo y negro. Editorial Académica Española.

98. De Lauretis, Teresa (1996). "La tecnología del género", en Revista Mora, № 2.

99. Del Campo, Hugo (1971). Los anarquistas, Buenos Aires, Centro Editor de América Latina.

100. Del Campo, Hugo (1983). Sindicalismo y peronismo. Los comienzos de un vínculo perdurable. Buenos Aires, Clacso.

101. Del Campo, Hugo (1986) El sindicalismo revolucionario (1905-1945), Buenos Aires, Centro Editor de América Latina.

102. Deleis, Mónica; Arguindeguy, D. L., y de Titto, Ricardo (2001). Mujeres de la política argentina. Buenos Aires, Aguilar.

103. Delgado, Josefina (2005). Salvadora. La dueña del diario Crítica. Buenos Aires, Sudamericana.

104. Delgado, Josefina (2007). "Estudio preliminar", en Las descentradas y otras piezas teatrales de Salvadora Medina Onrubia. Buenos Aires, Colihue.

105. Devoto, Fernando (1992). Asociacionismo, trabajo e identidad étnica: Los italianos en América Latina en una perspectiva comparada. Cemla-Cser-Iehs.

106. Devoto, Fernando (2003). Historia de la inmigración en la Argentina. Buenos Aires, Sudamericana.

107. Di Liscia, María Herminia (2000). "Maternidad y discurso maternal en la política sanitaria peronista", en Di Liscia, et al, Mujeres, maternidad y peronismo, Santa Rosa, Fondo Editorial Pampeano.

108. Di Stefano, M. (2005). "Políticas de lectura y escritura en las escuelas del anarquismo en la Argentina a principios del siglo XX. Cuadernos del Sur. Letras," (3536), 75-95. 
109. Diego Abad de Santillán (1930). El movimiento anarquista en la Argentina. Buenos Aires, Argonauta.

110. Diego Abad de Santillán (2005). La FORA. Ideología y trayectoria del movimiento obrero revolucionario en la Argentina. Buenos Aires, Libros de Anarres. (Primera edición 1933)

111. Doyon, Louise (1977) "Conflictos obreros durante el régimen peronista (1946-1955)", Desarrollo Económico, Vol 17, Nº 67, oct-nov.

112. Doyon, Louise (1984). "La organización del movimiento sindical peronista 1946 - 1955”, en Desarrollo Económico Vol. 24 N 94 (julio - septiembre)

113. Doyon, Louise (2006) Perón y los trabajadores. Los orígenes del sindicalismo peronista, 1943-1955. Buenos Aires, Siglo XXI Editora Iberoamericana.

114. Dujovne, Alicia (2008). "Cartografía de las publicaciones periódicas judías de izquierda en Argentina, 1900-1953", en Revista del Museo de Antropología, 1, 121138.

115. Etchenique, Jorge (2000). Pampa Libre. Anarquistas en la pampa argentina. Amerindia/Universidad Nacional de Quilmes.

116. Fagoaga, Concha (1985). La voz y el voto de las mujeres. El sufragismo en España, Barcelona, Icaria.

117. Falcón, Ricardo (2011). "Izquierdas, régimen político, cuestión étnica y cuestión social en Argentina (1890-1912)", en Estudios Sociales, 40 (1).

118. Feijoo, María del Carmen (1990). "Las trabajadoras porteñas", en Armus, Diego (comp.). Mundo urbano y cultura popular, Buenos Aires, Sudamericana.

119. Fernández Álvarez, Antón (1990). Ricardo Mella o el Anarquismo Humanista. Madrid, Editorial Anthropos.

120. Fernández Soria, Juan Manuel (1996). Cultura y libertad. La educación en las juventudes libertarias. Universidad de Valencia, Cuadernos del Departamento de Educación Comparada e Historia de la Educación.

121. Fiorucci, Flavia (2001). "El antiperonismo intelectual: de la guerra ideológica a la guerra espiritual", en XXIII Congreso Internacional de la Latin American Studies Association.

122. Fiorucci, Flavia (2004) "¿Aliados o enemigos? Los intelectuales en los gobiernos de Vargas y Perón". Estudios Interdisciplinarios de América Latina y el Caribe, Julio - Diciembre

123. Fiorucci, Flavia (2011). Intelectuales y peronismo: 1945-1955. Editorial Biblos.

124. Fletcher, Lea (1987). Una mujer llamada Herminia, Buenos Aires, Catálogos.

125. García Sebastiani, Marcela (2005). Los antiperonistas en la argentina peronista 1945-1951, Buenos Aires, Prometeo Libros

126. Ghigliani, Pablo (1998). "La Federación Gráfica Bonaerense Y la irrupción del peronismo", en Cuadernos del CISH, Vol. 3, n 4.

127. Ghigliani, Pablo (2009) "Dilemas de la democracia sindical: la Federación Gráfica bonaerense", en Belkin, Alejandro (comp.) Relatos de lucha 1. Contribuciones a la historia del movimiento obrero. Buenos Aires, Asociación de Trabajadores del Subte. 
128. Ginzburg, Carlo (2010). "Microhistoria: dos o tres cosas que sé de ella", en El hilo y las huellas, Buenos Aires, FCE.

129. González Aleman, Marianne (2012) "El conflicto callejero y el derecho de reunión en Buenos Aires durante la segunda presidencia de Irigoyen" en POLHIS, Año $5, \mathrm{~N}^{\circ} 9$.

130. Graciano, Osvaldo (2008). Entre la torre de marfil y el compromiso politico: intelectuales de izquierda en la Argentina, 1918-1955. Bernal, Universidad Nacional de Quilmes Editorial.

131. Graciano, Osvaldo (2012) "La escritura de la realidad. Un análisis de la tarea editorial y del trabajo intelectual del Anarquismo argentino entre los años ' $30 \mathrm{y}$ el Peronismo", www.izquierdas.cl, 12 de abril, pp. 72-110.

132. Gutiérrez, Leandro y Romero, Luis Alberto (2007). Sectores populares, cultura y política: Buenos Aires en la entreguerra. Buenos Aires, Siglo Veintiuno Editores.

133. Guy, Donna (2008). Women build the welfare state: Performing charity and creating rights in Argentina, 1880-1955. Duke University Press.

134. Guzzo, Cristina (2003). Las anarquistas rioplatenses. 1890-1990.

Phoenix, Orbis Press. Saítta, Sylvia (2006) "Prólogo", en Las descentradas. Buenos Aires, Tantalia.

135. Guzzo, Cristina (2014). Libertarias en América del Sur. De la A a la Z. Buenos Aires, Libros de Anarres.

136. Halperín Donghi, Tulio (1962) Historia de la Universidad de Buenos Aires, Buenos Aires, Eudeba. Mangone, Carlos y Warley, Jorge (1984) Universidad y peronismo (1946-1955), Buenos Aires, Centro Editor de América Latina.

137. Henault, Marta (1983). Alicia Moreau de Justo. Centro Editor de America Latina.

138. Hernun (2003) En torno a la anarquía. Sitio web:

http://entornoalaanarquia.com.ar/versionhtml/enta13.htm. Visitado por última vez $11 / 06 / 2014$

139. Herrera, Carlos (2003) "El Partido Socialista ante el peronismo, 1950. El debate Ghioldi-González", Taller. Revista de sociedad, cultura y política, Buenos Aires, $\mathrm{N}^{\circ} 21$, pp. 116-141.

140. Herrera, Carlos Miguel (2005). "¿La hipótesis de Ghioldi? El socialismo y la caracterización del peronismo (1943-1956)", en H. Camarero y C. Herrera (comps.), El Partido Socialista en la Argentina.Sociedad, política e ideas a través de un siglo, Buenos Aires, Prometeo.

141. Hobsbawm, ERIC (1998), Historia del Siglo XX. Barcelona, Editorial Siglo XXI.

142. Horowitz, Joel (2004). Los sindicatos, el estado y el surgimiento de Perón, 1930/1946. Editorial de la Universidad Nacional de Tres de Febrero.

143. Hurtado de Mendoza, Diego y Busala, A. (2002). Los ideales de universidad" científica," 1931-1959: elitismo y función social de la ciencia en la Argentina. Libros del Rojas, Universidad de Buenos Aires

144. Hurtado de Mendoza, Diego y Busala, A. (2006). "De la "movilización industrial" a la "Argentina científica": La organización de la ciencia durante el peronismo (1946-1955)". Revista da SBHC, Río de Janeiro, 4(1), 17-33. 
145. . Hurtado de Mendoza, Diego y Fernández, María José (2013). “Institutos privados de investigación "pura" versus políticas públicas de ciencia y tecnología en la Argentina (1943-1955)", en Asclepio, 65 (1)

146. Iñigo Carrera, Nicolás (2000). La estrategia de la clase obrera. 1936. Buenos Aires, La Rosa Blindada / Pimsa.

147. Iñigo Carrera, Nicolás (2006). "Alternativas revolucionarias en los 30: la Alianza Obrera Spartacus y el Partido Socialista Obrero", en Biagini, Hugo y Arturo Roig, El pensamiento alternativo del Siglo XX, t. II, Buenos Aires, Biblos.

148. Iñigo Carrera, Nicolás (s/d). "La Alianza Obrera Spartacus", en Cuadernos de Trabajo, PIMSA, No 26. 149. James, Daniel (1981). "Racionalización y respuesta de la clase obrera: contexto y limitaciones de la actividad gremial en la Argentina" en Desarrollo Económico, Vol. 21, nº 83, octubre - diciembre.

150. James, Daniel (2006). Resistencia e integración. El peronismo y la clase trabajadora argentina, 1946 - 1976. Buenos Aires, Siglo XXI.

151. Kappeli, Anne-Marie (1994). "Escenarios del feminismo", en Duby G. y Perrot M., Historia de las mujeres, tomo 8, Madrid.

152. Lahire, Bernard (2004) El Hombre Plural. Los resortes de la acción. Barcelona, Bellaterra.

153. Latour, Bruno (1983). "Give me a Laboratory and I Will Raise the Worl", en Knorr-Cetina, Karim y Michael Mulkay (eds.), Science Observed: Perspectives on the Social Study of Science, Londres, Sage, 141-170. Latour, B., \& Woolgar, S.

154. Latour, Bruno (1993). Nunca fuimos: ensayo de antropología moderna. Editorial Debate.

155. Latour, Bruno (1995). La vida en el laboratorio: la construcción de los hechos cientificos. Madrid, Anaya.

156. Latour, Bruno (2008). Reensamblar lo social: una introducción a la teoría del actor-red. Buenos Aires, Manantial.

157. Ledesma Prietto, Nadia (2012 a) "Revisando la categoría de intelectual para el anarquismo posterior a 1930. Un estudio de caso a través de Juan Lazarte, 19181963”, en Pasado por-venir; Lugar: Trelew, provincia de Chubut; Vol 6.

158. Ledesma Prietto, Nadia (2012 b). "Apuntes sobre la eugenesia y la libertad sexual en el discurso de dos médicos anarquistas. Argentina, 1930-1940”, en Nomadías, $\mathrm{N}^{\circ} 16$.

159. Ledesma Prietto, Nadia y Manzoni, Gisela (2010). "Pluma, Aguja y Barricadas: desafiando la hegemonía patriarcal", en Valobra, Adriana (edit.) Mujeres en espacios bonaerenses. La Plata, EDULP.

160. Little, Walter (1979). "La organización obrera peronista y el Estado peronista, 1943-1955" en Desarrollo Económico, Vol.19, Nº75, Buenos Aires, Págs. $331-375$.

161. Lobato, Mirta (2007). Historia de las trabajadoras en la Argentina (18691960). Buenos Aires, Edhasa.

162. López Trujillo, Fernando (2005). Vidas en Rojo y negro. Una historia del anarquismo en la Década Infame. La Plata, Letra Libre.

163. López Trujillo, Fernando (2010). “Acción Libertaria. Órgano de la Federación Anarco-Comunista Argentina. Luego: de la Federación Libertaria Argentina (1933-1971) 1" Parte: 1933-1943", en Publicaciones Periódicas Anarquistas (19251943). Publicaciones B.A.E.L (en cd room). 
164. López, Antonio y Rawin, Gregorio (2001). "The Jewish Rationalist Association of Argentina" en L'Anarchico e L'Ebreo: storia di un incontro. Milano, Eleuthera. Amedeo Bertolo e Annalisa Bertolo editors.

165. Luna, Lola (1994). "Estado y participación política de mujeres en América latina: una relación desigual y una propuesta de análisis histórico", en León, M. (coord.) Mujeres y participación política. Tercer mundo Editores, Bogotá.

166. Lunazzi, José María (1979). Futurología del taller y de la escuela. La Plata: Ediciones R.A.E.

167. Mainwaring, S. y Seibert, S. (1982). "El movimiento obrero y el peronismo, 1952-1955." Desarrollo económico, Vol. 21, No 84.

168. Manzoni, Gisela (2009). "Antimilitaristas y libertarias. La postura de las mujeres anarquistas ante el militarismo." I Jornadas CINIG de Estudios de Género y

Feminismos Teorías y políticas: desde el Segundo Sexo hasta los debates actuales 29 y 30 de Octubre.

169. Manzoni, Gisela (2012) "Madres anarquistas, hijos revolucionarios. La maternidad como estrategia de intervención pública", ponencia presentada en Congreso Latinoamericano de Historia de las Mujeres, San Juan, Argentina, 20 a 22 de septiembre.

170. Marotta, Sebastián (1960). El movimiento sindical argentino. Su génesis y su desarrollo. Tomos 1 y 2. Buenos Aires, Ediciones Lacio.

171. Marti, Alejandro (2010) Simón Radowitzky. Del atentado a Falcón a la Guerra Civil Española. De la Campana.

172. Pateman, Carol (1995). El contrato sexual. Madrid, Editorial Átropos.

173. Martínez Mazzola, Ricardo (2011). "Nacionalismo, peronismo, comunismo. Los usos del totalitarismo en el discurso del Partido Socialista Argentino (1946-1953)", en Prismas. Re vista de historia intelectual. vol.15 no.1 Bernal ene. / jun.

174. Martínez Prado, Natalia (2012). "Mujeres de otra raza": la irrupción del peronismo en el activismo femenino/feminista", en Identidades, Núm. 3, Año 2 Diciembre.

175. Mc Gee Deutsch, S. (2010). Crossing Borders, Claiming a Nation: A History of Argentine Jewish Women, 1880-1955, op. cit.

176. Miraux, Jean Philipe (2005). La autobiografia. La escritura del yo. Buenos Aires, Nueva Visión

177. Molinari, Irene (2008). "Obreras, operarias y empleadas. El trabajo de las mujeres en Mar del Plata, entre los años 1940 y 1960.”, en Trabajos y Comunicaciones, No 34. Pág. 158.

178. Molineux, Maxine (2001). "Género y ciudadanía en América Latina: cuestiones históricas y contemporáneas", en Debate feminista. Año 12, Vol. 23, México.

179. Molyneux, Maxine (1997) "Ni dios ni patrón ni marido. Feminismo anarquista en la Argentina del siglo XIX", en La Voz de la mujer. Periódico ComunistaAnárquico. 1896-1897, Buenos Aires, Universidad Nacional de Quilmes.

180. Mora y Araujo, M. y Llorente, I. (1980) (comps.). El voto peronista, Buenos Aires, Editorial Sudamericana.

181. Murmis, Miguel y Portantiero, Juan Carlos (1972). Estudios sobre los origenes del peronismo. Buenos Aires, Siglo XXI. 
182. Nardacchione, Gabriel (2011) "Reflexiones sobre la sociología de la ciencia de Bruno Latour y la sociología política de Luc Boltanski" en Lecturas en debate: apuntes de investigación del CECyP, Año XIV, No 19.

183. Nash, Mary "Experiencia y aprendizaje: la formación histórica de los feminismos en España", Historia Social, no20, 1994, pp. 151-172.

184. Nash, Mary (1999). Rojas. Las mujeres republicanas en la Guerra Civil, Madrid, Taurus.

185. Naum Krichmar (1964). La Colonia Narcisse Level (1909-1964).

Bernasconi, La Pampa, Cooperativa El Progreso.

186. Navarro, Marisa (2007). Evita Buenos Aires. Editorial Edhasa.

187. Nieto, Agustín (2008 a) "Anarquistas y obreras del pescado: Una experiencia de organización sindical en los años 40", en Historia Regional, Sección Historia, ISP $\mathrm{N}^{\mathrm{o}} 3$, año XXI, $\mathrm{N}^{\mathrm{o}} 26,2008$, pp. 89-117.

188. Nieto, Agustín (2008 b). "Conflictividad obrera en el puerto de Mar del Plata: del anarquismo al peronismo. El Sindicato Obrero de la Industria del Pescado, 1942-1948", Revista de Estudios Marítimos y Sociales, No 1, 35-44. 189. Norando, Verónica (2013). "Relaciones de género y militancia política: Las obreras textiles y el comunismo entre 1936 y 1946", en Trabajos y Comunicaciones, № 39.

190. Norando, Verónica y Ludmila Scheinkman (2011) "Roles sexuales y lucha de clases. La huelga de las obreras de la casa Gratry, Nueva Pompeya, 1936. Género y Clase en disputa", en Razón y Revolución , No 21

191. Otero, Hernán (2000). "Endogamia e integración de inmigrantes en la Argentina moderna. Balances y perspectivas desde un enfoque regional." Seminario sobre Población y Sociedad en América Latina, comp. Boleda and Mercado (Salta, Argentina, 2000).

192. Otero, Hernán (2010). "El asociacionismo francés en la Argentina. Una perspectiva secular.", en EIAL: Estudios Interdisciplinarios de America Latina y el Caribe, 21(2).

193. Oved, Iaacov (1991) "Influencia del anarquismo español sobre la formación del anarquismo argentino", en Revista estudios Interdisciplinarios de América Latina y el Caribe, Vol 2.1. S/nPagani, R. y Perego, E. (1989). La cuestión agraria en 1919: chacareros y terratenientes (Vol. 8). Centro Editor de América Latina.

195. Palermo, A. I. (2006). "El acceso de las mujeres a la educación universitaria. Revista argentina de sociología", 4 (7), 11-46.

196. Palermo, Silvana (1998). "El sufragio femenino en el Congreso Nacional: ideologías de género y ciudadanía en la Argentina (1916-1955)", en Boletín del Instituto de Historia Argentina y Americana Dr. Emilio Ravignani, $\mathrm{N}^{\circ} 16$.

197. Pascucci, Silvina (2007). Costureras, monjas y anarquistas: trabajo femenino, Iglesia y lucha de clases en la industria del vestido, Buenos Aires, 18901940 (Vol. 2). Ediciones RyR.

198. Pasolini, Ricardo (2013). Los marxistas liberales. Antifascismo y cultura comunista en la Argentina del siglo XX. Buenos Aire, Sudamericana.

199. Pavón, Iris Teresa (1952). Pasión de Justicia, Buenos Aires, Editorial Reconstruir.

200. Perrot, Michelle (2009). Mi historia de las mujeres. Buenos Aires, Fondo Cultura Económica. Pág. 8. 
201. Petra, Adriana (2001). "Anarquistas: cultura y luchas políticas en la

Buenos Aires finisecular. El anarquismo como estilo de vida", en

http://www.biblioteca.clacso.edu.ar/subida/clacso/becas/20101111073154/petra.pdf.

202. Petra, Adriana (2010) "Cosmopolitismo y nación. Los intelectuales comunistas

argentinos en tiempos de la Guerra Fría (1947-1956)" en Contemporánea.

Historia y problemas del siglo XX, Volumen 1, Año

203. Petra, Adriana (2013). "Intelectuales comunistas en la Argentina (19451963)", Tesis de posgrado. Presentada en Universidad Nacional de La Plata. Facultad de Humanidades y Ciencias de la Educación para optar al grado de Doctora en Historia.

204. Plotkin, Mariano. (1994). Mañana es San Perón: Propaganda, rituales políticos y educación en el régimen peronista (1946-1955). Buenos Aires, Ariel.

205. Portantiero, Juan Carlos (1978). Estudiantes y política en América Latina. 1918-1938. El proceso de la Reforma Universitaria. México, Siglo XXI.

206. Prol, María Mercedes (2008). "Arreglos institucionales en el régimen político del primer peronismo (1946-1955)", en Nuevo Mundo Mundos Nuevos, http://nuevomundo.revues.org/12592\#quotation.

207. Puiggros, Adriana (Dir.) (1995). Discursos Pedagógicos e imaginario social en el peronismo (1945-1955), Buenos Aires, Galerna.

208. Queirolo, Graciela (2010 a) "Herminia C. Brumana. La maternidad social a través del magisterio y de la escritura", en Adriana Valobra (ed.), Mujeres en espacios bonaerenses, Buenos Aires, EDULP.

209. Queirolo, Graciela (2010 b) "Las mujeres y los niños en el mercado de trabajo urbano (Buenos Aires, 1890-1940)", en Recalde, Héctor (comp.). Señoras, Universitarias y Mujeres (1910-2010). La Cuestión Femenina entre el Centenario y el Bicentenario de la Revolución de Mayo. Granada: Grupo Editor Universitario.

210. Quesada, Fernando (1974). El Proceso de Bragado. Buenos Aires, Editorial Korrigan

211. Ramacciotti, Karina y Valobra, Adriana, (2004) 'Plasmar la raza fuerte...' Relaciones de género en la propaganda sanitaria de la Secretaría de Salud Pública de la Argentina: 1947-1949, en Karina Ramacciotti y Adriana Valobra (compiladoras), Generando el peronismo. Estudios de cultura, política y género, Proyecto Editorial, Buenos Aires

212. Rocca, Carlos (1983) El Dr. Rafael Grinfeld o el precio de investigación cientifica en la Argentina, Eds. Geocart S.A., Buenos Aires.

213. Rocca, Carlos José (1998). José María Lunazzi. Semblanza de un Socialista Libertario. Editorial Universitaria de LA Plata

214. Ruocco, Laura (2009). "Mujeres obreras y sindicalismo anarquista. Dos paradigmas historiográficos", en Revista de Historia Bonaerense, № 35.

215. Saitta, Sylvia (1995) "Anarquismo, teosofía y sexualidad: Salvadora Medina Onrubia" en Mora, Revista del Area Interdisciplinaria de Estudios de la Mujer, Facultad de Filosofía y Letras, Universidad de Buenos Aires, $\mathrm{n}^{\mathrm{o}} 1$.

216. Saítta, Sylvia (1998). Regueros de tinta. El diario Crítica en la década de 1920, Buenos Aires, Sudamericana. Fletcher, Lea (1987) Una mujer llamada Herminia, Buenos Aires, Catálogos. 
217. Saltalamacchia, Homero (1997). "Los datos y su creación.”, en Revista Kryteria. Puerto Rico.

218. Samatán, Marta (1974). Herminia Brumana, la rebelde. Buenos Aires, Plus Ultra.

219. Sardu, A. (2008). "Una molesta piedra en el camino: Educación

Anarquista", en Theomai: estudios sobre sociedad, naturaleza y desarrollo, (17), 11. 220. Sarlo, Beatriz (2001). La batalla de las ideas, Buenos Aires, Editorial

Ariel.

221. Scarzanella, Eugenia (2009). "Mujeres y producción/consumo cultural en la Argentina peronista: las revistas de la editorial Abril", en Anuario de hojas de Warmi, $\mathrm{N}^{\mathrm{o}} 14$.

222. Schiavi, Marcos (2012). "Los sindicatos comunistas entre el 17 de octubre y su disolución. El caso textil y metalúrgico.", en Revista Trabajadores, $\mathrm{N}^{\mathrm{o}} 3$. http://www.revistatrabajadores.com.ar/index.php/Trabajadores/article/view/21. 223. Schiavi, Marcos (2012). "Organización y conflictividad textil: La Fábrica

Argentina de Alpargatas a comienzos del primer gobierno peronista", en Revista Mundos do Trabalho, Vol. 4, $\mathrm{N}^{\circ}$ 8. Disponible en

https://periodicos.ufsc.br/index.php/mundosdotrabalho/article/view/19849222.2012v4n8 p252.

224. Schneider, Alejandro (2005). Los compañeros. Trabajadores, izquierda y peronismo, 1955 - 1973. Buenos Aires, Ediciones Imago Mundid.

225. Scott, Joan (1990). "El género: una categoría útil para el análisis histórico", en Amelang, J. y Nash, M. Historia y género. Las mujeres en la Europa moderna y contemporánea. Alfons el Magnànim, València.

226. Scott, Joan (1993). "La mujer trabajadora en el siglo XIX", en Duby, George y Perrot, Michelle (editores). Historia de las mujeres en Occidente. Madrid, Taurus Ediciones.

227. Sidicaro, Ricardo (1999): "Consideraciones sociológicas sobre las relaciones entre el peronismo y clase obrera en la Argentina, 1943-1955", en Mackinnon, M.y Petrone, M. (comp.). Populismo y neopopulismo en América Latina. El problema de la Cenicienta, Buenos Aires, Eudeba.

228. Sigal, Silvia (2002). "Intelectuales y peronismo", en Juan Carlos Torre (coord.) Nueva Historia Argentina. Los años peronistas (1943-1955), T. VIII, Buenos Aires, Sudamericana. Torres, Juan Carlos (1990). "La vieja guardia sindical y perón." Sobre los orígenes del peronismo. Buenos Aires, Sudamericana.

229. Silva, Jeremías (2012). Las prisiones en la Nueva Argentina: Reforma penitenciaria, representaciones del castigo y usos políticos de las cárceles en el peronismo clásico (1946-1955). Tesis de Maestría en Ciencias Sociales). IDES-UNGS, Buenos Aires. 230. Silva, Jeremías (2012). "Las cárceles de la "Nueva Argentina": Administración del castigo y catolicismo durante el peronismo clásico", en Trabajos y Comunicaciones, 2da Época, $\mathrm{n}^{\circ}$ 38. http://trabajosycomunicaciones.fahce.unlp.edu.ar/. 231. Silva, Jeremías (2013). "Las políticas penitenciarias del estado nacional entre 1930 y 1960", en VII Jornadas de Sociología de la Universidad Nacional de La Plata." Argentina en el escenario latinoamericano actual: debates desde las ciencias sociales", La Plata.

232. Soprano, Germán (2009 a) "Política, instituciones y trayectorias académicas en la universidad argentina. Antropólogos y antropología en la Universidad Nacional de La Plata entre las décadas de 1930 y 1960", en Marquina, Mónica; 
Mazzola, Carlos y Soprano, Germán (comp.) Políticas, instituciones y protagonistas de la universidad argentina. Prometeo, Universidad Nacional de San Luis.

233. Soprano, Germán (2009b) “Autonomía universitaria e intervención política en la trayectoria de liderazgos y grupos académicos en Ciencias Naturales de la Universidad Nacional de La Plata 1930-1955", en Anuario del Instituto de Historia Argentina. (9) pp. 97-147.

234. Steinberg, RUDOLPH (1999) "El rugir de la multitud: repertorios discursivos y repertorios de acción colectiva de los hiladores de seda de Spitalfield, en el Londres del siglo XIX", en Auyero, Javier, Caja de herramientas. El lugar de la cultura en la sociología norteamericana, Buenos Aires, Editorial de la Universidad Nacional de Quilmes

235. Suriano, Juan (1997). "Las prácticas políticas del Anarquismo argentino", en Revista de Indias, $\mathrm{N}^{\circ} 57,421-450$.

236. Suriano, Juán (2001). Anarquistas: cultura y política libertaria en Buenos Aires, 1890-1910. Buenos Aires, Manantial.

237. Suriano, Juan (2002). "En defensa de los oprimidos: el anarquismo y la formación de una cultura de izquierda en la Argentina", en Prismas. Revista de historia intelectual. $\mathrm{N}^{\mathrm{o}} 6$.

238. Svampa, Maritella (2010). Certezas, incertezas y desmesuras de un pensamiento político: conversaciones con Floreal Ferrara. Buenos Aires, Biblioteca Nacional.

239. Tarcus, Horacio (2004 a). "Anarquismo y teosofía. Simón Radowitzky y Salvadora Medina Onrubia" en Politicas de la Memoria No 5, verano.

240. Tarcus, Horacio (2004 b). "Revistas, intelectuales y formaciones culturales izquierdistas en la Argentina de los 20", en Revista iberoamericana, 70(208), 749-772.

241. Tarcus, Horacio (2007). Diccionario biográfico de la izquierda argentina: de los anarquistas a la" nueva izquierda" 1870-1976. Buenos Aires, Emece Editores

242. Tarrow, Sidney (2004). El poder en movimiento: los movimientos sociales, la acción colectiva y la política. Madrid, Alianza editorial.

243. Tato, María Inés (2010). "En el nombre de la Patria: asociacionismo y nacionalismo en la Argentina en torno de la Primera Guerra Mundial.", en AAVV. 200 años de Iberoamérica (1810-2010), 303-315.

244. Tcach, César (2003). La invención del peronismo en el interior del país. Secretaría de Extensión, Universidad Nacional del Litoral.

245. Terán, O. (2008). Historia de las ideas en Argentina. Diez lecciones iniciales. Buenos Aires, Siglos XXI.

246. Torrado, Susana. (2003). Historia de la familia en la Argentina moderna (1870-2000). Buenos Aires, ediciones de la Flor.

247. Torre, Juan Carlos (2004). El gigante invertebrado. Los sindicatos y en el gobierno, Argentina 1973 - 1976, Buenos Aires, Siglo XXI.

248. Vallejo, Gustavo (2007). Escenarios de la cultura científica argentina. Ciudad y Universidad (1882-1955). Madrid, Consejo Superior de Investigaciones Científicas.

249. Valobra, Adriana (2005 a). "Tradiciones y Estrategias de Movilización Social en los Partidos Opositores Durante el Peronismo. El Caso del Partido Comunista 
y la Unión de Mujeres de la Argentina", en Canadian Journal of Latin American and Caribbean Studies, 30(60), 155-182.

250. Valobra, Adriana (2005 b) "Partidos, tradiciones y estrategias de movilización social: de la Junta de la Victoria a la Unión de Mujeres de la Argentina", en Prohistoria, No 9, Rosario

251. Valobra, Adriana (2007). "La tradición femenina en el radicalismo y la lucha de Clotilde Sabattini por el reconocimiento de la equidad política, 1946-1955." Clepsydra, $\mathrm{N}^{\circ} 6$.

252. Valobra, Adriana (2008). "La ciudadanía política de las mujeres y las elecciones de 1951", en Anuario de Historia Argentina, № 8.

253. Valobra, Adriana María (2010) Del hogar a las urnas. Recorridos de la ciudadanía política femenina. Argentina, 1946-1955. Rosario, Prohistoria Ediciones.

254. Valobra, Adriana (2011) "Prácticas y debates sobre los derechos políticos de las mujeres en la UCR y el PCA, 1946-1955”, en Barry, Carolina (comp.) Sufragio femenino. Prácticas y debates políticos, religiosos y culturales en Argentina y América Latina, EDUNTREF.

255. Van Dijk, T. A. (2000). El discurso como interacción social: estudios del discurso, inroducción multidisciplinaria. Gedisa. Van Dijk, Teun (1980). "Algunas notas sobre la ideología y la teoría del discurso", en Semiosis, $N^{o} 5$ Jalapa, Mexico, 3754 .

256. Verón, Eliseo (1987). "El discurso político" en La palabra adversativa. Observaciones sobre la enunciación política. Hachette

257. Viñao, Antonio (2004). Escuela para todos: educación y modernidad en la España del siglo XX. Marcial Pons Historia, Madrid.

258. Wodak, R. (2003). De qué trata el análisis crítico del discurso (ACD). "Resumen de su historia, sus conceptos fundamentales y sus desarrollos", en AAVV. Métodos de análisis crítico del discurso, $\mathrm{s} / \mathrm{d}$.

259. Wodak, R., y Fairclough, N. (2000). "Análisis crítico del discurso", en AAVV. El discurso como interacción social: estudios del discurso, inroducción multidisciplinaria (pp. 367-404). Madrid, Gedisa.

260. Yusta Rodrigo, Mercedes (2005). "Las mujeres en la resistencia antifranquista, un estado de la cuestión", en Arenal Revista de Historia de las Mujeres, $\mathrm{N}^{\mathrm{o}}$ 12. enero-junio

261. Yusta Rodrigo, Mercedes (2011). "La construcción de una cultura política femenina desde el antifascismo (1934-1950)", en Aguado, Ana y Ortega, teresa (dir.). Feminismos y antifeminismos. Culturas políticas e identidades de género en la España del Siglo XX. Valencia, PUV.

262. Zanatta, Loris (1996). Del estado liberal a la nación católica. Universidad nacional de Quilmes.

263. Zaragoza Rovira, Gonzalo (1996). Anarquismo argentino, 1876-1902.

Medir, Ediciones de la Torre. 